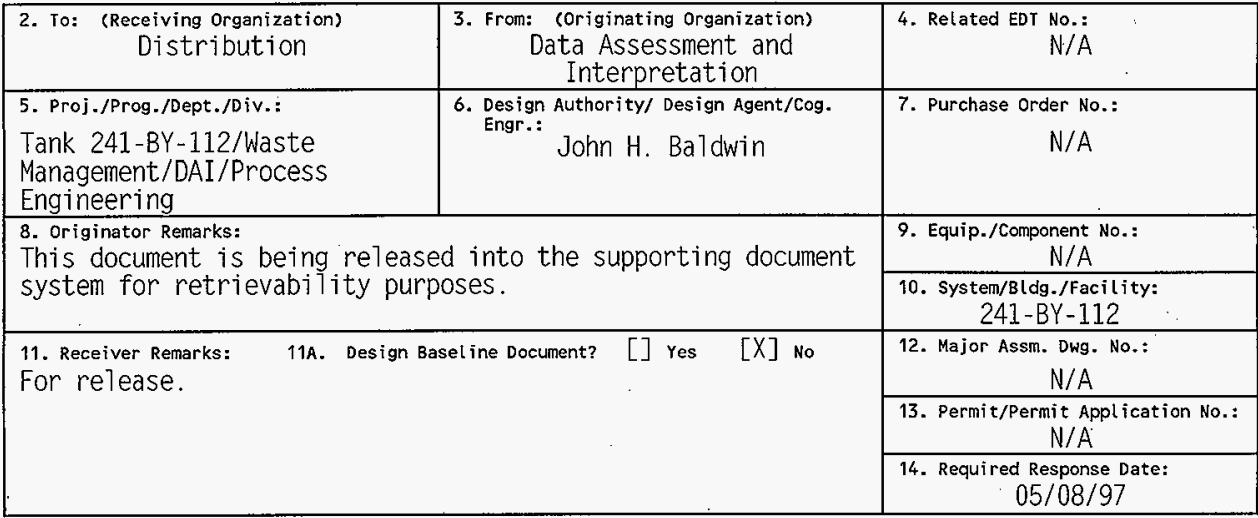

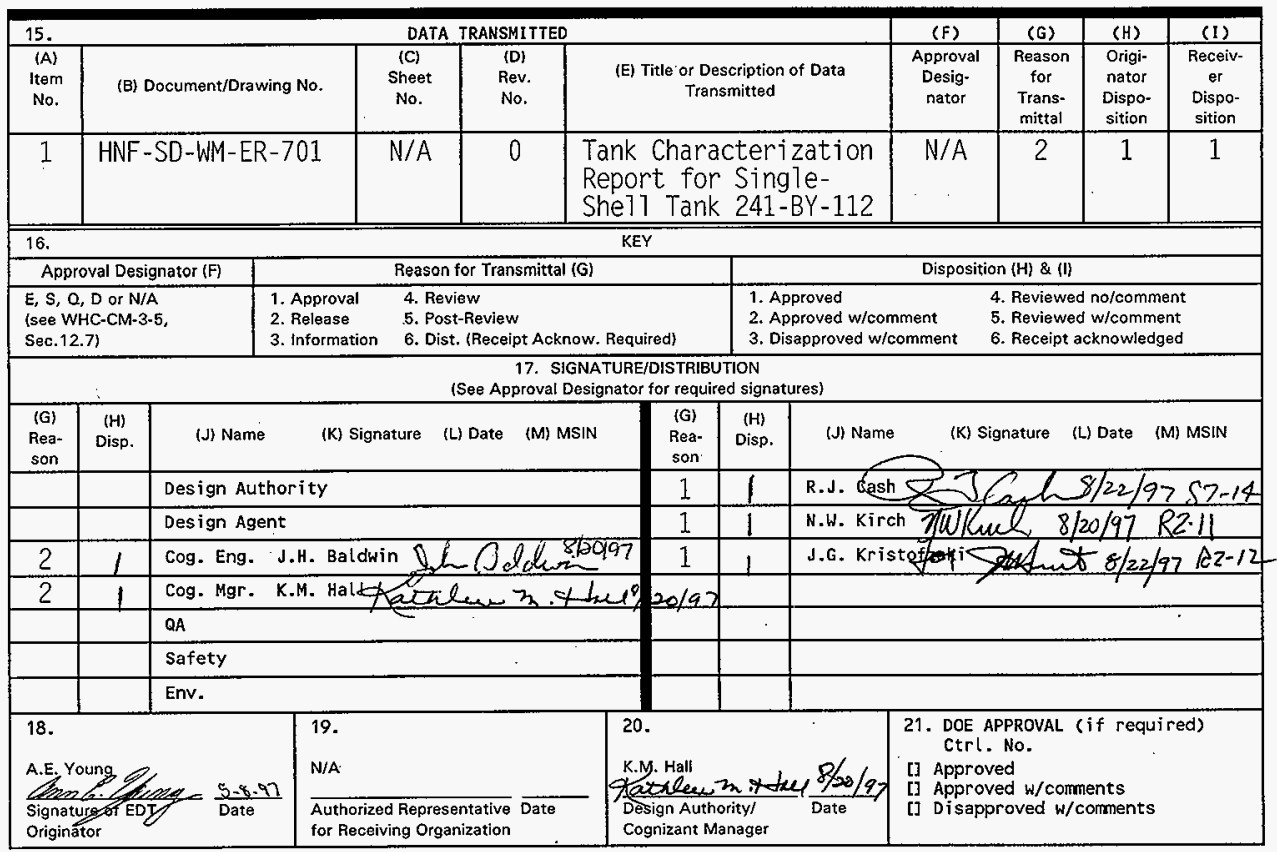

BD-7400-172-2 (05/96) GEF097 
BLOCK TITLE

$(1)^{*}$ EDT

(2) To: (Recoiving Organization)

(3) From: (Originating Organization)

(4) Related EDT No.

(5)* Proj./Prog./Dept./Div.

(6) * Design Authority ffor Design Baseline Documents)/Cognizant Engineer (for all others)/Design Agent

(7) Purchase Order No

(8) * Originator Remarks

(9) Equipment/Component No.

(10) System/Blig./Facility

(11) Receiver Remarks

(11A) Design Baseline Dooument

(12) Major Assm. Dwg. No.

(13) Permit/Permit Application No.

(14) Required Response Date

(15)* Data Transmitted

(A) * Item Number

(B) * Document/Drawing No.

(C) * Sheet No.

(D) * Rev. No.

(E) Title or Description of Data Transmitted

(F) * Approval Designator

(G) Reason for Transmittal

(H) Originator Disposition

(I) Receiver Disposition

(16) Koy

(17)

Signature/Distribution

(G) Resson
(H) Disposition
(J) Name
(K)* Signature
(L)* Date
(M)* MSIN

Signature of EDT Originator

Authorized Representative for Receiving Organization

(20)* Cognizant Manager

$(21)^{*}$ DOE Approval
- Pre-assigned EDT number.

- Enter the individual's rame, title of the organization, or entity (e.g.. Distribution) that the EDT is being transmitted to.

- Enter the titie of the organization originating and transmitting the EDT.

- Enter EDT numbers which relate to the data being transmitted.

- Enter the Project/Program/Department/Division titie or Project/Program acronym or Project Number, Work Order Number or Organization Code.

- Enter the name of the individual identified as being responsible for coordinating disposition of the EDT.

- Enter related Purchase Order (P.O.) Number, if available.

- Enter special or additional commente conceming transmittal, or "Key" retrieval words may be entered.

- Enter equipment/component number of affected item, if appropriate.

- Enter applicable system, building or facility number, if appropriate.

- Enter special or additional comments conceming transmittal.

- Enter an " $\mathrm{X}$ " in the appropriate box. Consult with Design Authority for identification of Design Baseline Documents, if required.

- Enter applicable drawing number of major assembly, if appropriate.

- Enter applicable permit or permit application number, if appropriate.

- Enter the date a response is required from individuals identified in Block 17 (Signature/Distribution).

- Enter sequential number, beginning with 1, of the information listed on EDT.

- Enter the unique identification number assigned to the document or drawing being tranemitted.

- Enter the sheot number of the information being transmitted. If no sheet number, leave blank.

- Enter the revision number of the informotion being tranemitted. If no revision number, leave blank.

- Enter the title of the document or drawing or a brief description of the subject if no title is identified.

- Enter the appropriate Approval Designator (Block 15). Also, indicate the appropriate approvals for each item listed, i.e.. SQ, ESQ, otc.

- Enter the appropriate code to identify the purpose of the data transmittal (6ee Block 16).

- Enter the appropriate disposition cods (see Block 16).

- Enter the appropriate disposition code (see Block 16).

- Number codes used in completion of Blocks 15 (G), (H), and (f), and 17 (G), (H) (Signature/Distribution).

- Enter the code of the reason for transmittal (Block 16).

- Enter the code for the disposition (Block 16).

- Enter the signature of the individual completing the Disposition $17(\mathrm{H})$ and the Transmittal.

- Obtain appropriete signature(s).

- Enter date signature is obtained.

- Enter MSIN. Note: If Distribution Sheet is used, show entire distribution (including that indicated on Page 1 of the EDT) on the Distribution Sheet.

- Enter the signature and date of the individual originating the EDT fentered prior to transmittal to Receiving Organization). If the EDT originator is the Desien Authority (for Design Baseline Documents)/Cognizant Engineer (for all others) or Design Agent, sign both Blocks 17 and 18 .

- Enter the signature and date of the individual identified by the Receiving Organization Design Authority (for Design Baseline Documents)/Cognizant Engineer (for all others) as authorized to spprove disposition of the EDT and acceptance of the data transmitted, as applicable.

- Enter the signature and date of the cognizant manager. (This signature is authorization for release.) This signature is not required if the Design Authority is approving the document.

- Enter DOE approval (if required) by signature or control number that tracks the approval to a signature, and indicate DOE action. 


\section{Tank Characterization Report for Single-Shell Tank 241-BY-112}

John H. Baldwin

Lockheed Martin Hanford Corp., Richland, WA 99352

U.S. Department of Energy Contract DE-AC06-87RL10930

$\begin{array}{lll}\text { EDT/ECN: } & \text { EDT-617661 } & \text { UC: } 2070 \\ \text { Org Code: } & 74620 & \text { Charge Code: N4G4C } \\ \text { B\&R Code: } & \text { EW } 3120074 & \text { Total Pages: 190 }\end{array}$

Key Words: Waste Characterization, Single-She11 Tank, SST, Tank 241-BY112, Tank BY-112, BY-112, BY Farm, Tank Characterization Report, TCR, Waste Inventory, TPA Milestone M-44

Abstract: This document summarizes the information on the historical uses, present status, and the sampling and analysis results of waste stored in Tank 241-BY-112. This report supports the requirements of the Tri-Party Agreement Mi lestone M-44-10.

TRADEMARK DISCLAIMER. Reference herein to any specific commercial product, process; or service by trade name, trademark, manufacturer, or otherwise, does not necessarily constitute or imply its endorsement, recommendation, or favoring by the United States Government or any agency thereof or its contractors or subcontractors.

Printed in the United States of America. To obtain copies of this document, contact: WHC/BCS Document Control Services, P.0. Box 1970, Mailstop H6-08, Richland WA 99352, Phone (509) 372-2420; Fax (509) 376-4989.
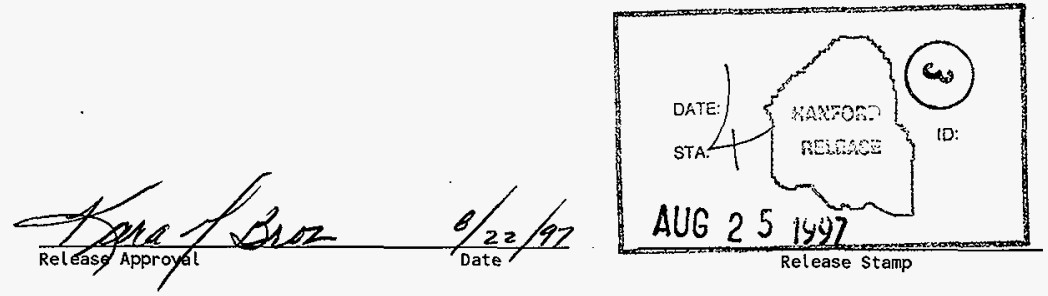

\section{Approved for Public Release}




\title{
Tank Characterization Report for Single-Shell Tank 241-BY-112
}

\author{
J. H. Baldwin \\ M. J. Kupfer \\ Lockheed Martin Hanford Corporation \\ R. D. Cromar \\ Numatec Hanford Corporation \\ R. T. Winward \\ Meier Associates \\ L. Fergestrom \\ Technical Resources International
}

Date Published

August 1997

Prepared for the U.S. Department of Energy

Assistant Secretary for Environmental Management

Project Hanford Management Contractor for the

U.S. Department of Energy under Contract DE-AC06-96RL13200

Approved for public release; distribution is unlimited 


\section{CONTENTS}

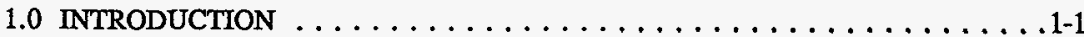

1.1 SCOPE . . . . . . . . . . . . . . . . . .

1.2 TANK BACKGROUND $\ldots \ldots \ldots \ldots \ldots \ldots \ldots \ldots \ldots \ldots \ldots \ldots$

2.0 RESPONSE TO TECHNICAL ISSUES $\ldots \ldots \ldots \ldots \ldots \ldots \ldots \ldots \ldots \ldots \ldots . \ldots \ldots$

2.1 SAFETY SCREENING $\ldots \ldots \ldots \ldots \ldots \ldots \ldots \ldots \ldots \ldots \ldots \ldots .1$

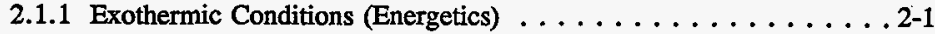

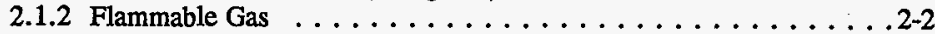

2.1 .3 Criticality . . . . . . . . . . . . . . . .

2.1.4 Total Organic Carbon $\ldots \ldots \ldots \ldots \ldots \ldots \ldots \ldots \ldots \ldots \ldots .2-2$

2.2 HAZARDOUS VAPOR SAFETY SCREENING $\ldots \ldots \ldots \ldots \ldots \ldots .2-3$

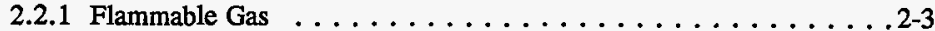

2.2 .2 Toxicity $\ldots \ldots \ldots \ldots \ldots \ldots \ldots \ldots \ldots \ldots \ldots \ldots \ldots \ldots \ldots .2-3$

2.3 ORGANIC SOLVENTS $\ldots \ldots \ldots \ldots \ldots \ldots \ldots \ldots \ldots \ldots \ldots .2-3$

2.4 OTHER TECHNICAL ISSUES $\ldots \ldots \ldots \ldots \ldots \ldots \ldots \ldots \ldots \ldots$

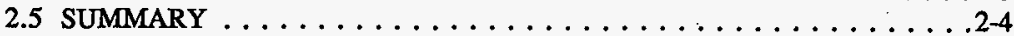

3.0 BEST-BASIS STANDARD INVENTORY ESTIMATE $\ldots \ldots \ldots \ldots \ldots$. . . . .

4.0 RECOMMENDATIONS $\ldots \ldots \ldots \ldots \ldots \ldots \ldots \ldots \ldots \ldots \ldots . \ldots \ldots$

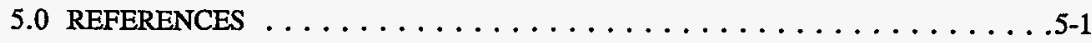

APPENDIXES

APPENDIX A HISTORICAL TANK INFORMATION $\ldots \ldots \ldots \ldots \ldots \ldots$ A-1

A1.0 CURRENT TANK STATUS $\ldots \ldots \ldots \ldots \ldots \ldots \ldots \ldots \ldots \ldots$ A-3

A2.0 TANK DESIGN AND BACKGROUND $\ldots \ldots \ldots \ldots \ldots \ldots \ldots$ A-4

A3.0 PROCESS KNOWLEDGE $\ldots \ldots \ldots \ldots \ldots \ldots \ldots \ldots \ldots \ldots \ldots$ A-9

A3.1 WASTE TRANSFER HISTORY $\ldots \ldots \ldots \ldots \ldots \ldots \ldots \ldots$. . . . . .

A3.2 HISTORICAL ESTIMATION OF TANK CONTENTS $\ldots \ldots \ldots \ldots$ A-13

A4.0 SURVEILLANCE DATA $\ldots \ldots \ldots \ldots \ldots \ldots \ldots \ldots \ldots \ldots \ldots \ldots$ A-21

A4.1 SURFACE-LEVEL READINGS $\ldots \ldots \ldots \ldots \ldots \ldots \ldots \ldots \ldots$ A-21

A4.2 DRY WELL READINGS . . . . . . . . . . . . A-21

A4.3 INTERNAL TANK TEMPERATURES . . . . . . . . . A-21

A4.4 TANK 241 -BY-112 PHOTOGRAPHS $\ldots \ldots \ldots \ldots \ldots \ldots \ldots \ldots$ A-22 


\section{CONTENTS (Continued)}

A5.0 APPENDIX A REFERENCES $\ldots \ldots \ldots \ldots \ldots \ldots \ldots \ldots \ldots \ldots$ A-25

APPENDIX B SAMPLING OF TANK $241-B Y-112 \ldots \ldots \ldots \ldots \ldots$ B-1

B1.0 TANK SAMPLING OVERVIEW $\ldots \ldots \ldots \ldots \ldots \ldots \ldots \ldots$ B-3

B2.0 SAMPLING EVENTS $\ldots \ldots \ldots \ldots \ldots \ldots \ldots \ldots \ldots \ldots \ldots$ B-3

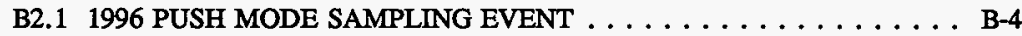

B2.1.1 Sample Handling $\ldots \ldots \ldots \ldots \ldots \ldots \ldots \ldots \ldots$ B-5

B2.1.2 Sample Analysis $\ldots \ldots \ldots \ldots \ldots \ldots \ldots \ldots \ldots \ldots$ B-8

B2.1.3 Analytical Results . . . . . . . . . . . . B-11

B2.2 ANALYTICAL DATA TABLES $\ldots \ldots \ldots \ldots \ldots \ldots \ldots$. . . $\ldots \ldots$

B2.2.1 Safety Screening and Flammable Gas Monitoring . . . . . . B-63

B2.2.2 1994 Tank Vapor Samples . . . . . . . . . . . . . . B-63

B2.3 HISTORICAL SAMPLE RESULTS . . . . . . . . . . . . B-65

B2.3.1 January 1972 Sample Results . . . . . . . . . . . . . B-65

B2.3.2 April 1971 Sample Results . . . . . . . . . . . . . B-65

B3.0 ASSESSMENT OF CHARACTERIZATION RESULTS $\ldots \ldots \ldots \ldots \ldots \ldots$. . . . . .

B3.1 FIELD OBSERVATIONS $\ldots \ldots \ldots \ldots \ldots \ldots \ldots \ldots \ldots \ldots$. . . . . . $\ldots 8$

B3.2 QUALITY CONTROL ASSESSMENT . . . . . . . . . B-68

B3.2.1 Differential Scanning Calorimetry Analysis . . . . . . . B-69

B3.2.2 Thermogravimetric Analysis . . . . . . . . . . . . B-69

B3.2.3 Density . . . . . . . . . . . . . . . B-69

B3.2.4 Total Alpha Analysis . . . . . . . . . . . . . . . B-70

B3.2.5 Total Organic Carbon . . . . . . . . . . . . . B-70

B3.3 DATA CONSISTENCY CHECKS . . . . . . . . . . . . . . B-71

B3.3.1 Comparison of Results from Different Analytical Methods . . . B-71

B3.3.2 Mass and Charge Balance . . . . . . . . . . . B-71

B3.4 MEAN CONCENTRATIONS AND CONFIDENCE INTERVALS $\ldots .$. B-74

B3.4.1 Liquid and Solid Segment Means . . . . . . . . . . . B-74

B3.4.2 Analysis of Variance Models . . . . . . . . . . . B-79

B4.0 APPENDIX B REFERENCES $\ldots \ldots \ldots \ldots \ldots \ldots \ldots \ldots \ldots \ldots$ B-81

APPENDIX C STATISTICAL ANALYSIS FOR ISSUE RESOLUTION . . . . . . . C-1

C1.0 STATISTICS FOR SAFETY SCREENING DQO . . . . . . . . C C-3

C2.0 STATISTICS FOR THE ORGANIC DATA QUALITY OBJECTIVE . . . . . C C 6

C3.0 APPENDIX C REFERENCES $\ldots \ldots \ldots \ldots \ldots \ldots \ldots \ldots \ldots$ C-9 


\section{CONTENTS (Continued)}

APPENDIX D EVALUATION TO ESTABLISH BEST-BASIS INVENTORY

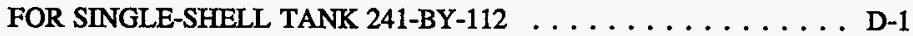

D1.0 CHEMTCAL INFORMATION SOURCES . . . . . . . . . . D-3

D2.0 COMPARISON OF COMPONENT INVENTORY VALUES $\ldots \ldots \ldots \ldots$ D-3

D3.0 COMPONENT INVENTORY EVALUATION . . . . . . . . . D D 5 D3.1 EXPECTED TYPE OF WASTE BASED ON THIS ASSESSMENT $\ldots$ D-6 D3.2 ASSUMPTIONS USED . . . . . . . . . . . . . . . D-7 D3.3 BASIS FOR CALCULATIONS USED IN THIS EVALUATION $\ldots \ldots$ D-7 D3.4 ESTIMATED COMPONENT INVENTORIES . . . . . . . . . D-13

D4.0 DEFINE THE BEST-BASIS AND ESTABLISH COMPONENT INVENTORIES . . . . . . . . . . . . . . . . D-15

D5.0 APPENDIX D REFERENCES $\ldots \ldots \ldots \ldots \ldots \ldots \ldots \ldots \ldots \ldots$ D-22 APPENDIX E BIBLIOGRAPHY FOR TANK 241-BY-112 . . . . . . . . E-1 


\section{LIST OF FIGURES}

A2-1 Riser Configuration for Tank $241-B Y-112 \ldots \ldots \ldots \ldots \ldots \ldots \ldots$. . . . . . .

A2-2 Tank 241-BY-112 Cross Section and Schematic . . . . . . . . . . . . A-8

A3-1 Tank Layer Model $\ldots \ldots \ldots \ldots \ldots \ldots \ldots \ldots \ldots \ldots \ldots$. . . . . . . . . .

A4-1 Tank 241-BY-112 Level History $\ldots \ldots \ldots \ldots \ldots \ldots \ldots \ldots \ldots \ldots$. . . . . . . . . . . .

A4-2 Tank 241-BY-112 Weekly High Temperature Plot . . . . . . . . . . . . . . A A-24

\section{LIST OF TABLES}

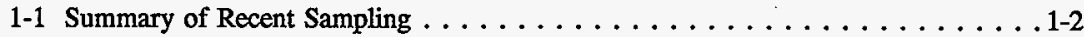

1-2 Description of Tank $241-\mathrm{BY}-112 \ldots \ldots \ldots \ldots \ldots \ldots \ldots \ldots \ldots \ldots$

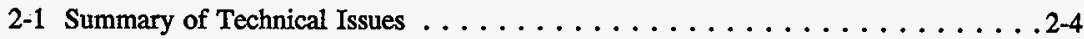

3-1 Best-Basis Inventory Estimates for Nonradioactive Components in Tank 241-BY-112 (Effective May 31, 1997) . . . . . . . . . . . . . . . . . . . 3-3

3-2 Best-Basis Inventory Estimates for Radioactive Components in Tank 241-BY-112 Decayed to January 1, 1994 (Effective May 31, 1997) . . . . . . . . . . . . 3-4

4-1 Acceptance of Tank 241-BY-112 Sampling and Analysis . . . . . . . . 4-1

4-2 Acceptance of Evaluation of Characterization Data and Information for Tank $241-\mathrm{BY}-112 \ldots \ldots \ldots \ldots \ldots \ldots \ldots \ldots$. . . . . . . . .

A1-1 Tank Contents Status Summary $\ldots \ldots \ldots \ldots \ldots \ldots \ldots \ldots$ A

A2-1 Tank 241-BY-112 Risers $\ldots \ldots \ldots \ldots \ldots \ldots \ldots \ldots \ldots \ldots \ldots$ A-5

A3-1 Tank 241-BY-112 Major Waste Transfers . . . . . . . . . . . . . . A-10

A3-2 Historical Tank Inventory Estimate $\ldots \ldots \ldots \ldots \ldots \ldots \ldots$. . . . . . . . . . . .

B2-1 Integrated Data Quality Objective Requirements for Tank 241-BY-112 . . . . B-4 


\section{LIST OF TABLES (Continued)}

B2-2 Sample Receipt and Extrusion Information

for Tank $241-B Y-112$, Core $174 \ldots \ldots \ldots \ldots \ldots \ldots \ldots$ B-6

B2-3 Sample Receipt and Extrusion Information for Tank 241-BY-112, Core 177 . . B-7

B2-4 Tank 241-BY-112 Sample Analysis Summary . . . . . . . . . . . . B-8

B2-5 Analytical Tables $\ldots \ldots \ldots \ldots \ldots \ldots \ldots \ldots \ldots \ldots \ldots$. . . . . . .

B2-6 Tank 241-BY-112 Analytical Results: Aluminum (ICP) $\ldots \ldots \ldots \ldots \ldots$. . . . . . .

B2-7 Tank 241-BY-112 Analytical Results: Antimony (ICP) . . . . . . . . . . . B-15

B2-8 Tank 241-BY-112 Analytical Results: Arsenic (ICP) . . . . . . . . . . . B-16

B2-9 Tank 241-BY-112 Analytical Results: Barium (ICP) $\ldots \ldots \ldots \ldots \ldots$. . . . B-17

B2-10 Tank 241-BY-112 Analytical Results: Beryllium (ICP) $\ldots \ldots \ldots \ldots \ldots$. . B-18

B2-11 Tank 241-BY-112 Analytical Results: Bismuth (ICP) . . . . . . . . . . B-19

B2-12 Tank 241-BY-112 Analytical Results: Boron (ICP) . . . . . . . . . . . . B-20

B2-13 Tank 241-BY-112 Analytical Results: Cadmium (ICP) $\ldots \ldots \ldots \ldots \ldots$. . . B-21

B2-14 Tank 241-BY-112 Analytical Results: Calcium (ICP) . . . . . . . . . . . B-22

B2-15 Tank 241-BY-112 Analytical Results: Cerium (ICP) . . . . . . . . . . B-23

B2-16 Tank 241-BY-112 Analytical Results: Chromium (ICP) . . . . . . . . . . . B-24

B2-17 Tank 241-BY-112 Analytical Results: Cobalt (ICP) $\ldots \ldots \ldots$. . . . . . B-25

B2-18 Tank 241-BY-112 Analytical Results: Copper (ICP) $\ldots \ldots \ldots \ldots \ldots \ldots$. . . B-26

B2-19 Tank 241-BY-112 Analytical Results: Iron (ICP) . . . . . . . . . . . . B-27

B2-20 Tank 241-BY-112 Analytical Results: Lanthanum (ICP) . . . . . . . . . . . B-28

B2-21 Tank 241-BY-112 Analytical Results: Lead (ICP) . . . . . . . . . . . . . B-29

B2-22 Tank 241-BY-112 Analytical Results: Lithium (ICP) . . . . . . . . . . . . B-30 


\section{LIST OF TABLES (Continued)}

B2-23 Tank 241-BY-112 Analytical Results: Magnesium (ICP) $\ldots \ldots \ldots \ldots \ldots$. . . B B2-24 Tank 241-BY-112 Analytical Results: Manganese (ICP) . . . . . . . . . B B-32

B2-25 Tank 241-BY-112 Analytical Results: Molybdenum (ICP) . . . . . . . . B-33 B2-26 Tank 241-BY-112 Analytical Results: Neodymium (ICP) . . . . . . . . . B B-34 B2-27 Tank 241-BY-112 Analytical Results: Nickel (ICP) $\ldots \ldots \ldots \ldots \ldots$. . . . B-35 B2-28 Tank 241-BY-112 Analytical Results: Phosphorus (ICP) $\ldots \ldots \ldots \ldots \ldots$. . . . . .

B2-29 Tank 241-BY-112 Analytical Results: Potassium (ICP) $\ldots \ldots \ldots$. . . . . B-36 B2-30 Tank 241-BY-112 Analytical Results: Samarium (ICP) $\ldots \ldots \ldots \ldots \ldots$ B-36

B2-31 Tank 241-BY-112 Analytical Results: Selenium (ICP) . . . . . . . . . . . B B-37 B2-32 Tank 241-BY-112 Analytical Results: Silicon (ICP) $\ldots \ldots \ldots \ldots \ldots$. . . . . . . . B2-33 Tank 241-BY-112 Analytical Results: Silver (ICP) . . . . . . . . . . . . . B-39 B2-34 Tank 241-BY-112 Analytical Results: Sodium (ICP) . . . . . . . . . . . B-40 B2-35 Tank 241-BY-112 Analytical Results: Strontium (ICP) $\ldots \ldots \ldots \ldots \ldots$. . . . . . B2-36 Tank 241-BY-112 Analytical Results: Sulfur (ICP) . . . . . . . . . . . . B-42 B2-37 Tank 241-BY-112 Analytical Results: Thallium (ICP) . . . . . . . . . . . B-43 B2-38 Tank 241-BY-112 Analytical Results: Titanium (ICP) . . . . . . . . . . . B-44 B2-39 Tank 241-BY-112 Analytical Results: Total Uranium (ICP) $\ldots \ldots \ldots \ldots$. . B-45 B2-40 Tank 241-BY-112 Analytical Results: Vanadium (ICP) . . . . . . . . . B-46 B2-41 Tank 241-BY-112 Analytical Results: Zinc (ICP) . . . . . . . . . . . . B-47 B2-42 Tank 241-BY-112 Analytical Results: Zirconium (ICP) . . . . . . . . . . B-48 B2-43 Tank 241-BY-112 Analytical Results: Bromide (IC) . . . . . . . . . . . . B-49 


\section{LIST OF TABLES (Continued)}

B2-44 Tank 241-BY-112 Analytical Results: Chloride (IC) . . . . . . . . . . . B-50

B2-45 Tank 241-BY-112 Analytical Results: Fluoride (IC) $\ldots \ldots \ldots \ldots \ldots \ldots$ B-51

B2-46 Tank 241-BY-112 Analytical Results: Nitrate (IC) $\ldots \ldots \ldots \ldots \ldots \ldots$. . . . . .

B2-47 Tank 241-BY-112 Analytical Results: Nitrite (IC) $\ldots \ldots \ldots \ldots \ldots \ldots$ B-53

B2-48 Tank 241-BY-112 Analytical Results: Phosphate (IC) $\ldots \ldots \ldots \ldots \ldots$. . .54

B2-49 Tank 241-BY-112 Analytical Results: Sulfate (IC) $\ldots \ldots \ldots \ldots \ldots \ldots$. . . . . . . .

B2-50 Tank 241-BY-112 Analytical Results: Oxalate (IC) . . . . . . . . . . B-56

B2-51 Tank 241-BY-112 Analytical Results: Bulk Density $\ldots \ldots \ldots \ldots \ldots$. . . . . . .

B2-52 Tank 241-BY-112 Analytical Results: Exotherm - Transition 1 Wet (DSC) . . B-58

B2-53 Tank 241-BY-112 Analytical Results: Percent Water (TGA) . . . . . . . . . B-59

B2-54 Tank 241-BY-112 Analytical Results: Specific Gravity . . . . . . . . . . B-60

B2-55 Tank 241-BY-112 Analytical Results: Total Alpha (Alpha) . . . . . . . . B-60

B2-56 Tank 241-BY-112 Analytical Results: Total Inorganic Carbon . . . . . . . . B-61

B2-57 Tank 241-BY-112 Analytical Results: Total Organic Carbon . . . . . . . . . B-62

B2-58 Results of Vapor Measurements of Tank 241-BY-112 . . . . . . . . . B-64

B2-59 Result of Vapor Analysis in Headspace of Tank 241-BY-112 . . . . . . . . B-64

B2-60 Tank $241-B Y-112$ Sample $\ldots \ldots \ldots \ldots \ldots \ldots \ldots \ldots \ldots \ldots$. . . . . . . .

B2-61 Tank 241-BY-112 Sample . . . . . . . . . . . . . . . . B-67

B3-1 Differential Scanning Calorimetry Relative Percent Differences Exceeding 20

Percent . . . . . . . . . . . . . . . . . . . . . . . . . . B-69

B3-2 Cation Mass and Charge Data $\ldots \ldots \ldots \ldots \ldots \ldots \ldots$. . . . . . . .

B3-3 Anion Mass and Charge Data $\ldots \ldots \ldots \ldots \ldots \ldots \ldots \ldots$ B-73 


\section{LIST OF TABLES (Continued)}

B3-4 Mass Balance Totals $\ldots \ldots \ldots \ldots \ldots \ldots \ldots \ldots \ldots \ldots$ B-74

B3-5 95 Percent Two-Sided Confidence Interval for the Mean Concentration for Solid Segment Sample Data . . . . . . . . . . . . . . . . . B-75

B3-6 95 Percent Two-Sided Confidence Interval for the Mean Concentration for Liquid Segment Sample Data . . . . . . . . . . . . . . . . . . B-77

C1-1 95 Percent Confidence Interval Upper Limits for Alpha

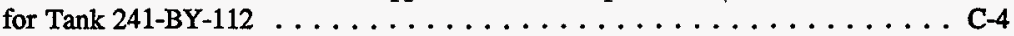

C1-2 95 Percent Confidence Interval Upper Limits for Differential Scanning Calorimetry Exotherms for Tank 241-BY-112 . . . . . C-5

C1-3 95 Percent Confidence Interval Lower Limits for Percent Water for Tank $241-B Y-112 \ldots \ldots \ldots \ldots \ldots \ldots \ldots \ldots \ldots \ldots$

C1-4 95 Percent Confidence Interval Upper Limits for TOC for Tank 241-BY-112 . C C-8

D2-1 Sample-Based and Hanford Defined Waste-Based Inventory Estimates for Nonradioactive Components in Tank 241-BY-112 . . . . . . . . . . D D 4

D2-2 Sample- and HDW Model-based Inventory Estimates for Radioactive Components in Tank 241-BY-112 . . . . . . . . . . D-5

D3-1 Assessment Methodology Used For Tank 241-BY-112 . . . . . . . . . . D D-8

D3-2 Concentrations of Components in BY Tank Farm Saltcake Samples . . . . . D-10

D3-3 Tank 241-BY-112 Inventory Calculations . . . . . . . . . . D-12

D3-4 Comparison of Selected Component Inventory Estimates for Tank 241-BY-112 Waste . . . . . . . . . . . . . . . . D-14

D4-1 Best-Basis Inventory Estimates for Nonradioactive Components in Tank 241-BY-112 (Effective May 31, 1997) . . . . . . . . . . . D-18

D4-2 Best-Basis Inventory Estimates for Radioactive Components in Tank 241-BY-112 Decayed to January $1,1994 \ldots \ldots \ldots \ldots \ldots \ldots$. . . . . . . . 


\section{LIST OF TERMS}

\begin{tabular}{|c|c|}
\hline ANOVA & analysis of variance \\
\hline $\mathrm{AT}$ & alpha total \\
\hline BNW & Battelle Northwest Laboratory waste \\
\hline $\mathrm{Btu} / \mathrm{hr}$ & British thermal units per hour \\
\hline BYCOND & Liquid condensed by in-tank evaporators and sent to cribs \\
\hline BYSltCk & BY saltcake \\
\hline $\mathrm{Ci}$ & curie \\
\hline CI & confidence interval \\
\hline $\mathrm{Ci} / \mathrm{g}$ & curies per gram \\
\hline $\mathrm{Ci} / \mathrm{L}$ & curies per liter \\
\hline $\mathrm{cm}$ & centimeter \\
\hline $\mathrm{cm}^{3}$ & cubic centimeter \\
\hline $\mathrm{CW}$ & cladding waste \\
\hline CWP2 & cladding waste from PUREX \\
\hline DQO & data quality objective \\
\hline DSC & differential scanning calorimetry \\
\hline EB & Evaporator bottoms \\
\hline EB-ITS & Evaporator bottoms from in-tank solidification \\
\hline EVAP & Evaporator feed waste \\
\hline $\mathrm{ft}$ & feet \\
\hline g & gram \\
\hline $\mathrm{g} / \mathrm{L}$ & grams per liter \\
\hline $\mathrm{g} / \mathrm{cm}^{3}$ & grams per cubic centimeter \\
\hline $\mathrm{g} / \mathrm{mL}$ & grams per milliliter \\
\hline $\mathrm{HDW}$ & Hanford defined waste \\
\hline IC & ion chromatography \\
\hline ICP & inductively coupled plasma \\
\hline in. & inch \\
\hline in. $^{3}$ & cubic inches \\
\hline ITS & in-tank solidification \\
\hline ITS1 & first in-tank solidification unit \\
\hline ITS2 & second in-tank solidification unit \\
\hline IX & ion-exchange waste \\
\hline $\mathrm{J} / \mathrm{g}$ & joules per gram \\
\hline $\mathrm{kg}$ & kilogram \\
\hline kgal & kilogallon \\
\hline kL & kiloliter \\
\hline kW & kilowatt \\
\hline
\end{tabular}




\section{LIST OF TERMS (Continued)}

L

LEL

LFL

LL

m

$\mathrm{mL}$

$\mathrm{mm}$

$\mathrm{m}^{2}$

$M$

$\mathrm{mg} / \mathrm{m}^{3}$

MW

$\mathrm{n} / \mathrm{a}$

NR

$\mathrm{PFeCN}_{2}$

PHMC

ppmv

PUREX

REML

RPD

SACS

SC

SL

SMM

SU

TBP-F

TCR

TGA

TIC

TLM

TOC

TWRS

UL

W

WSTRS liter

lower explosive limit

lower flammability limit

lower limit

meter

milliliter

millimeter

square meter

molarity

milligrams per cubic meter

metal waste from the bismuth phosphate process

not applicable

not reported

Ferrocyanide sludge produced by scavenging uranium recovery supernatant

Project Hanford Management Contractor

parts per million by volume

plutonium-uranium extraction (plant)

restricted maximum likelihood estimation

relative percent difference

Surveillance Analysis Computer System

saltcake

sludge

supernatant mixing model

supernatant

Tributyl phosphate-ferrocyanide scavenged uranium recovery (TBP) supernatants (equivalent to PFeCN)

tank characterization report

thermogravimetric analysis

total inorganic carbon

tank layer model

total organic carbon

Tank Waste Remediation System

upper limit

watt

Waste Status and Transaction Record Summary 
HNF-SD-WM-ER-701 Rev. 0

\section{LIST OF TERMS (Continued)}

$\begin{array}{ll}\text { wt\% } & \text { weight percent } \\ { }^{\circ} \mathrm{C} & \text { Celsius } \\ { }^{\circ} \mathrm{F} & \text { Fahrenheit } \\ \% & \text { percent } \\ \mu \mathrm{Ci} / \mathrm{g} & \text { microcuries per gram } \\ \mu \mathrm{Ci} / \mathrm{L} & \text { microcuries per liter } \\ \mu \mathrm{Ci} / \mathrm{mL} & \text { microcuries per millimeter } \\ \mu \mathrm{eg} / \mathrm{g} & \text { microequivalents per gram } \\ \mu \mathrm{g} / \mathrm{g} & \text { micrograms per gram } \\ \mu \mathrm{g} / \mathrm{mL} & \text { micrograms per milliliter }\end{array}$


HNF-SD-WM-ER-701 Rev. 0

This page intentionally left blank. 


\subsection{INTRODUCTION}

One major function of the Tank Waste Remediation System (TWRS) is to characterize wastes in support of waste management and disposal activities at the Hanford Site. Analytical data from sampling and analysis and other available tank information are compiled and maintained in a tank characterization report (TCR). This report and its appendixes serve as the TCR for single-shell tank 241-BY-112.

The objectives of this report are: 1) to use characterization data in response to technical issues associated with tank 241-BY-112 waste and 2) to provide a standard characterization of this waste in terms of a best-basis inventory estimate. Section 2.0 summarizes the response to technical issues, Section 3.0 provides the best basis inventory estimate, and Section 4.0 makes recommendations regarding safety status and additional sampling needs. The appendices contain supporting data and information. This report also supports the requirements of the Hanford Federal Facility Agreement and Consent Order (Ecology et al. 1996), Milestone M-44-10.

\subsection{SCOPE}

Characterization information in this report originated from sample analyses and known historical sources. Although only the results of recent sample events will be used to fulfill the requirements of the data quality objectives (DQOs), other information can be used to support (or question) conclusions derived from these results. Appendix A provides historical information for tank 241-BY-112 including surveillance information, records pertaining to waste transfers and tank operations, and expected tank contents derived from a process knowledge model.

Appendix B summarizes information on the recent sampling events (see Table 1-1), sample data obtained before 1989, and sampling results. The results of the 1996 sampling events, also reported in the laboratory data package (Nuzum 1997), satisfied the data requirements specified in the tank characterization plan for this tank (Baldwin and Winkelman 1996). Appendix $\mathrm{C}$ reports on the statistical analysis and numerical manipulation of data used in issue resolution. Appendix D contains the evaluation to establish the best basis for the inventory estimate and the statistical analysis performed for this evaluation. Appendix $E$ is a bibliography that resulted from an in-depth literature search of all known information sources applicable to tank 241-BY-112 and its respective waste types. The reports listed in Appendix $E$ are available in the Tank Characterization and Safety Resource Center. 
Table 1-1. Summary of Recent Sampling.

\begin{tabular}{|c|c|c|c|c|}
\hline 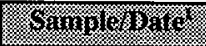 & 11148 & S. & 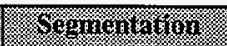 & Ferecit Tecrules \\
\hline $\begin{array}{l}\text { Combustible gas } \\
\text { test } \\
(10 / 2 / 96 \text { and } \\
10 / 7 / 96)\end{array}$ & Gas & $\begin{array}{l}\text { Tank headspace, } \\
\text { risers } 18 \text { and } \\
216.1 \mathrm{~m}(20 \mathrm{ft}) \\
\text { below top of riser }\end{array}$ & $\mathrm{n} / \mathrm{a}$ & $n / a$ \\
\hline \multirow[t]{2}{*}{$\begin{array}{l}\text { Push mode } \\
\text { sampling } \\
(10 / 2 / 96 \text { to } \\
10 / 3 / 96) \\
\text { Core } 174\end{array}$} & Solid & \multirow[t]{2}{*}{ Riser 18} & 6 segments & $\begin{array}{l}\text { Segment recovery } \\
\text { varied from } 26 \text { to } \\
95 \% \text {. }\end{array}$ \\
\hline & Liquid & & $\begin{array}{l}\text { Recovered only in } \\
\text { segment } 5\end{array}$ & $n / a$ \\
\hline \multirow[t]{2}{*}{$\begin{array}{l}\text { Push mode } \\
\text { sampling } \\
(10 / 7 / 96) \\
\text { Core } 177\end{array}$} & Solid & \multirow[t]{2}{*}{ Riser 21} & 6 segments & $\begin{array}{l}\text { Segment recovery } \\
\text { varied from } 21 \text { to } \\
74 \% \text {. }\end{array}$ \\
\hline & Liquid & & $\begin{array}{l}\text { Recovered only in } \\
\text { segment } 5\end{array}$ & $n / a$ \\
\hline $\begin{array}{l}\text { Vapor sample } \\
(11 / 18 / 94)\end{array}$ & Gas & Tank headspace & $n / a$ & $n / a$ \\
\hline
\end{tabular}

Notes:

$\mathbf{n} / \mathbf{a}=$ not applicable

${ }^{1}$ Dates are given in the month/day/year format.

\subsection{TANK BACKGROUND}

Tank 241-BY-112 is located in the 200 East Area BY Tank Farm on the Hanford Site. It is the last tank in a three-tank cascade series. Tank 241-BY-112 began receiving metal waste from B Plant during the second quarter of 1951. During the first and fourth quarters of 1952, the tank received metal waste through the cascade from tank 241-BY-111. During the second, third, and fourth quarters of 1952, tank 241-BY-112 again received metal waste from B Plant.

During the first quarter of 1955, metal waste sludge was sent to tank 241-BY-111. In the second quarter of 1955, the tank received metal waste from B Plant. During 1956, tank 241-BY-112 received supernatant from tanks 241-BY-106, 241-BY-107, and 
241-BY-108. During the second quarter of 1957, ferrocyanide sludge was received, and supernatant was sent to the B-028 and B-029 cribs. During the third and fourth quarters of 1957, tank 241-BY-112 received supernatant from tank 241-C-105.

The tank remained static until 1965 when supernatant was sent to tanks 241-BY-109, 241-BY-101, and 241-BY-103. Tank 241-BY-112 received supernatant from tanks 241-C-102 and 241-BY-111 from the third quarter of 1965 to the third quarter of 1996. During the fourth quarter of 1967, tank 241-BY-112 received cladding waste from PUREX.

In 1966, a heater was placed in the tank to cause evaporation (ITS2). During late 1967 and early 1968, tank 241-BY-112 received waste from cell 23 at B Plant. Cell 23 was used to evaporate tank waste. From the first quarter of 1968 to the second quarter of 1976, the tank received waste from the first in-tank solidification unit (ITS1) tank 241-BY-102 as well as other single-shell tanks in the 200 East Area. During this same time, waste was transferred from tank 241-BY-112 to other single-shell tanks in the 200 East Area.

For additional information on the amount of liquid evaporated during the ITS process from 1968 to 1976, see Appendix A.

Interstitial liquor was salt well pumped to tank 241-AW-102 in the third quarter of 1982.

Table 1-2 summarizes the description of tank 241-BY-112. The tank has an operating capacity of $2,870 \mathrm{~kL}(758 \mathrm{kgal})$ and contains an estimated $1,101 \mathrm{~kL}(291 \mathrm{kgal})$ of noncomplexed waste (Hanlon 1997). The tank is not on the Watch List (Public Law 101-510). 
Table 1-2. Description of Tank 241-BY-112.

\begin{tabular}{|c|c|}
\hline (2) - & 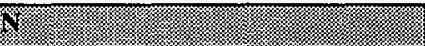 \\
\hline Type & Single-shell \\
\hline Constructed & 1948 to 1949 \\
\hline In-service & 1951 \\
\hline Diameter & $23 \mathrm{~m}(75 \mathrm{ft})$ \\
\hline Operating depth & $7.2 \mathrm{~m}(23.67 \mathrm{ft})$ \\
\hline Capacity & $2,870 \mathrm{~kL}(758 \mathrm{kgal})$ \\
\hline Bottom Shape & Dish \\
\hline Ventilation & Passive \\
\hline 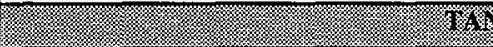 & \\
\hline Waste classification & Noncomplexed \\
\hline Total waste volume $^{i}$ & $1,101 \mathrm{~kL}(291 \mathrm{kgal})$ \\
\hline Supernatant volume & $0 \mathrm{~kL}(0 \mathrm{kgal})$ \\
\hline Saltcake volume & $1,080 \mathrm{~kL} \mathrm{(286 \textrm {kgal } )}$ \\
\hline Sludge volume & $20 \mathrm{~kL}(5 \mathrm{kgal})$ \\
\hline Drainable interstitial liquid volume & $30 \mathrm{~kL}(8 \mathrm{kgal})$ \\
\hline Waste surface level (October 3, 1996) & $2.87 \mathrm{~m} \mathrm{(113 \textrm {in } . )}$ \\
\hline $\begin{array}{l}\text { Temperature (August } 1974 \text { to December } \\
\text { 1996) }\end{array}$ & $5^{\circ} \mathrm{C}\left(41^{\circ} \mathrm{F}\right)$ to $62.2^{\circ} \mathrm{C}\left(144^{\circ} \mathrm{F}\right)$ \\
\hline Integrity & Sound \\
\hline Watch List & None \\
\hline s.s. & \\
\hline Vapor sample & November 1994 \\
\hline Push mode core samples & October 1996 \\
\hline : & 48 \\
\hline Declared inactive & 1977 \\
\hline Interim stabilization & 1984 \\
\hline Intrusion prevention & 1991 \\
\hline
\end{tabular}

Note:

${ }^{\mathrm{L}}$ Waste volume is estimated from surface-level measurements. 


\subsection{RESPONSE TO TECHNICAL ISSUES}

The following technical issues have been identified for $\operatorname{tank} 241-\mathrm{BY}-112$.

Safety screening:

- Does the waste pose or contribute to any recognized potential safety problems?

Hazardous vapor safety screening:

- Does a potential exist for worker hazards associated with the toxicity of constituents in tank fugitive vapor emissions.

Organic Solvents:

- Does an organic solvent pool exist that may cause an organic solvent pool fire or ignition of organic solvents entrained in waste solids?

The tank characterization plan (Baldwin and Winkelman 1996) identifies the types of sampling and analysis that were used to address the above issues. Data from the recent analysis of two core samples, tank vapor space flammability measurements, and historical information are the means to respond to the issues. This response is detailed below. Appendix B contains the sample and analysis data for tank 241-BY-112.

\subsection{SAFETY SCREENING}

The data needed to screen the waste in tank 241-BY-112 for potential safety problems are documented in the Tank Safety Screening Data Quality Objective (Dukelow et al. 1995). These potential safety problems are exothermic conditions in the waste, flammable gases in the waste and/or tank headspace, and criticality conditions in the waste. Each condition is addressed separately. Because tank 241-BY-112 is not a Watch List tank, the safety screening DQO was the only safety-related DQO associated with the sampling effort.

\subsubsection{Exothermic Conditions (Energetics)}

The first requirement outlined in the safety screening DQO (Dukelow et al. 1995) is to ensure there is not enough fuel in tank 241-BY-112 to cause a safety hazard. Because of this requirement, energetics in tank 241-BY-112 waste were evaluated. The safety screening DQO required that the waste sample profile be tested for energetics every $24 \mathrm{~cm}(9.5 \mathrm{in}$.) to determine whether the energetics exceeded the safety threshold limit. Because of poor recovery, only four of 12 segments met this condition. 
The threshold limit for energetics is $480 \mathrm{~J} / \mathrm{g}$ on a dry weight basis. Results obtained using differential scanning calorimetry (DSC) indicated no exotherms exceeded the threshold limit. (Nuzum 1996). However, because of sample heterogeneity, three samples exceeded the limit of $480 \mathrm{~J} / \mathrm{g}$ at the upper 95 percent confidence level of the mean on a dry basis (see Appendix C). The percent water for these same samples exceeded 25 percent (see Appendix C), and the total organic carbon (TOC) for these samples was less than the limit of $30,000 \mu \mathrm{g} / \mathrm{g}$; therefore, no DSC safety concern exists for tank 241-BY-112.

Historically, any exothermic agent in tank BY-112 should be low. Waste transfer records indicate that the major waste type expected to be in the tank is BY saltcake. An ITS system was operated in tank 241-BY-112. The ITS used electric emersion heaters and an airlift recirculator to concentrate nonboiling aqueous (or supernatant) waste directly inside the tank. The heat from the ITS would drive off organics in the waste and degrade ferrocyanide. Ferrocyanide and organics are the primary sources of exotherms in Hanford Site waste tanks.

\subsubsection{Flammable Gas}

Vapor phase measurements, which were taken in the tank headspace before the push mode samples in October 1996, indicated flammable gas was detected at 1.0 percent of the lower flammability limit (LFL). Appendix B provides data from these vapor phase measurements.

\subsubsection{Criticality}

The safety threshold limit is $1 \mathrm{~g}{ }^{239} \mathrm{Pu}$ per liter of waste. Assuming that all alpha is from ${ }^{239} \mathrm{Pu}$ and with a measured density of $1.46 \mathrm{~g} / \mathrm{mL}, 1 \mathrm{~g} / \mathrm{L}$ of ${ }^{239} \mathrm{Pu}$ is equivalent to $42 \mu \mathrm{Ci} / \mathrm{g}$ of alpha activity. Alpha activity in all samples was less than $0.2 \mu \mathrm{Ci} / \mathrm{g}$, well below this limit. Additionally, as required by the DQO, the upper limit of the one-sided 95 percent confidence interval on the mean for these results was less than $42 \mu \mathrm{Ci} / \mathrm{g}$. Appendix $\mathrm{C}$ provides the method used to calculate confidence limits. Criticality is not a concern for this tank.

\subsubsection{Total Organic Carbon}

The dry weight notification limit for TOC is $30,000 \mu \mathrm{g} / \mathrm{g}$. Three samples exceeded the notification limit at the upper 95 percent confidence level of the mean (see Appendix C). The percent water measured for these samples exceeds 23 percent (see Appendix C). The DSC measured for these samples is less than the limit of $480 \mathrm{~J} / \mathrm{g}$. The low results associated with the relatively high TOC values indicates a majority of the measured carbon is no longer associated with hydrogen-containing compounds; therefore, it is not reactive. No safety concern exists for tank 241-BY-112. 


\subsection{HAZARDOUS VAPOR SAFETY SCREENING}

The data required to support vapor screening are documented in Data Quality Objective for Tank Hazardous Vapor Safety Screening (Osborne and Buckley 1995). Does the vapor headspace exceed 25 percent of the LFL? If so, what are the principal fuel components? Are compounds of toxicological significance present in the tank vapor at such a level that the industrial hygiene group shall be alerted to their presence so adequate breathing zone monitoring can be accomplished and future activities in and around the tank can be performed in a safe manner?

\subsubsection{Flammable Gas}

This is the same requirement as the safety screening flammability requirement. See Section 2.1.2 for a treatment of the flammability issue.

\subsubsection{Toxicity}

The vapor screening DQO (Osborne and Buckley 1995) requires the analysis of tank vapor samples for ammonia $\left(\mathrm{NH}_{3}\right)$, carbon dioxide $\left(\mathrm{CO}_{2}\right)$, carbon monoxide $(\mathrm{CO})$, nitric oxide (NO), nitrous oxide $\left(\mathrm{N}_{2} \mathrm{O}\right)$, and nitrogen dioxide $\left(\mathrm{NO}_{2}\right)$. The vapor screening DQO specifies a threshold limit for each above listed compound. All components were well below the threshold limit. The worker toxicity issue has been resolved, and the resolution is documented in Hewitt (1996).

\subsection{ORGANIC SOLVENTS}

A new DQO is being developed to address the organic solvent issue. In the interim, tanks are to be sampled for total nonmethane hydrocarbon to determine whether an organic solvent pool with an area greater than $1 \mathrm{~m}^{2}$ exists (Cash 1996). The purpose of this assessment is to ensure that any organic solvent pool is sufficiently small that an organic solvent pool fire or ignition of organic solvents cannot occur. The size of the organic solvent pool will be determined by the organic program based on the vapor data, tank headspace temperature, and the tank ventilation rate.

\subsection{OTHER TECHNICAL ISSUES}

A factor in assessing tank safety is the heat generation and temperature of the waste. Heat is generated in the tanks primarily from radioactive decay. The heat load estimate based on the tank process history is 2,020 W (6,900 Btu/hr) (Agnew et al. 1997b). The heat load estimate based on the tank headspace temperature is $1,786 \mathrm{~W}(6,100 \mathrm{Btu} / \mathrm{hr}$ ) (Kummerer 
1995). Both estimates are well below the limit of $11,700 \mathrm{~W}(40,000 \mathrm{Btu} / \mathrm{hr})$ that separates high- and low-heat-load tanks (Smith 1986).

\subsection{SUMMARY}

The results from all analyses performed to address potential safety issues show TOC exceeded the safety threshold limit for two samples. The DSC for these samples were low indicating the carbon is not associated with reactive compounds.

These samples exceeded the DSC threshold at the upper 95 percent confidence interval on the mean because of sample heterogeneity. Although recovery was not adequate to provide DSC results for every $24 \mathrm{~cm}(9.5 \mathrm{in}$.) of the core, the history of the tank suggests the fuel content in the tank is not a concern. The analyses do not indicate a safety concern for tank 241-BY-112. Table 2-1 summarizes the results of the analyses results.

Table 2-1. Summary of Technical Issues.

\begin{tabular}{|c|c|c|}
\hline thisie & 算 & 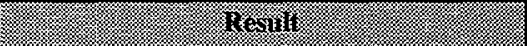 \\
\hline \multirow[t]{4}{*}{ Safety } & Energetics & $\begin{array}{l}\text { Three samples exceeded } 480 \mathrm{~J} / \mathrm{g} \text { at the } \\
\text { upper } 95 \% \text { confidence level of the mean. } \\
\text { However, this is a result of sample } \\
\text { heterogeneity and does not indicate a safety } \\
\text { concern. }\end{array}$ \\
\hline & Flammable gas & $\begin{array}{l}\text { Vapor measurement reported } 1.0 \text { percent of } \\
\text { LFL. (Combustible gas meter). }\end{array}$ \\
\hline & Criticality & $\begin{array}{l}\text { All analyses were well below } 42 \mu \mathrm{Ci} / \mathrm{g} \\
\text { total alpha (within } 95 \text { percent confidence } \\
\text { limit on each sample). }\end{array}$ \\
\hline & TOC & $\begin{array}{l}\text { Three samples exceeded } 30,000 \mu \mathrm{g} / \mathrm{g} \text {. } \\
\text { However, the carbon measured is not } \\
\text { associated with reactive compounds and } \\
\text { does not indicate a safety concern. }\end{array}$ \\
\hline $\begin{array}{l}\text { Hazardous } \\
\text { vapor }\end{array}$ & Toxicity & This issue has been resolved. \\
\hline $\begin{array}{l}\text { Organic } \\
\text { solvents }\end{array}$ & Solvent pool size & $\begin{array}{l}\text { Total nonmethane hydrocarbon was not } \\
\text { measured. The size of the organic solvent } \\
\text { pool will be estimated from vapor results } \\
\text { obtained. }\end{array}$ \\
\hline
\end{tabular}




\subsection{BEST-BASIS STANDARD INVENTORY ESTIMATE}

Information about the chemical and/or physical properties of tank wastes is used to perform safety analyses, engineering evaluations, and risk assessments associated with waste management activities, as well as to address regulatory issues. Waste management activities include overseeing tank farm operations and identifying, monitoring, and resolving safety issues associated with these operations and with the tank wastes. Disposal activities involve designing equipment, processes, and facilities for retrieving wastes and processing the wastes into a form suitable for long-term storage.

Chemical inventory information generally is derived using two approaches: 1) component inventories are estimated using the results of sample analyses, and 2) component inventories are predicted using a model based on process knowledge and historical information. The most recent model was developed by Los Alamos National Laboratory (Agnew et al. 1997a). Not surprisingly, information derived from these two different approaches is often inconsistent.

An effort is underway to provide waste inventory estimates that will serve as standard characterization source terms for the various waste management activities (Hodgson and LeClair 1996). As part of this effort, an evaluation of available chemical information for tank 241-BY-112 was performed including the following.

- Data from recent analyses of two push-mode core samples collected in October 1996 (see Appendix B)

- An inventory estimate generated by the Hanford Defined Waste (HDW) model (Agnew et al. 1997a)

- Evaluation of BY saltcake data from other BY Tank Farm tanks

Based on this evaluation, a best-basis inventory was developed for tank 241-BY-112. For the following reasons, the sampling-based inventory was chosen as the best basis for those analytes for which sampling-based analytical values were available:

- The sample-based inventory analytical concentrations compared favorably to those of other BY evaporator tanks with the ITS1 unit or direct outsource tanks. Except for noted exceptions, there were good comparisons to all BY farm tanks.

- No methodology is available to fully predict BY saltcake from process flowsheet or historical records.

- Waste transfer records are not complete and not always accurate. 
For those few analytes for which no values could be calculated from the sample-based inventory, the engineering evaluation data or the HDW model values were used. These values are less reliable than the values for which sample data are available.

Based on this evaluation, a best-basis inventory was developed for tank 241-BY-112. When the sample-based inventory had a high less-than value or was not measured, the engineering assessment-based values were used (if applicable). Some high less than values are reported because all three tanks used in the engineering assessment had high less than values. Results for radionuclides were not available for the sample-based inventory. The best basis radionuclide values were either engineering assessment values based on the heat load of tank 241-BY-112 from Kummerer (1995) or HDW values. The HDW model was used only where no other data were available. Tables 3-1 and 3-2 show the best-basis inventory for tank 241-BY-112.

Once the best-basis inventories were determined, the hydroxide inventory was calculated by performing a charge balance with the valences of other analytes. In some cases, this approach required that other analyte (for example, sodium or nitrate) inventories be adjusted to achieve the charge balance. During such adjustments, significant figures are retained. No such adjustments were necessary in this tank. This charge balance approach is consistent with that used by (Agnew et al. 1997a).

Best-basis tank inventory values were derived for 46 key radionuclides (defined in Kupfer et al. 1997). The radionuclides were decayed to a common report date of January 1, 1994. Often, waste sample analyses reported only ${ }^{90} \mathrm{Sr},{ }^{137} \mathrm{Cs},{ }^{239 / 40} \mathrm{Pu}$, and total uranium, or (total beta and total alpha) while other key radionuclides such as ${ }^{60} \mathrm{Co},{ }^{99} \mathrm{Tc},{ }^{129} \mathrm{~T},{ }^{154} \mathrm{Eu},{ }^{155} \mathrm{Eu}$, and ${ }^{241} \mathrm{Am}$ were reported infrequently. For this reason, it was necessary to derive most of the 46 key radionuclides by computer models. These models estimated radionuclide activity in batches of reactor fuel, accounted for the split of radionuclides to various separations plant waste streams, and tracked their movement with tank waste transactions. (These computer models are described in Kupfer et al. 1997 (Section 6.1) and Watrous and Wootan 1997.) Model generated values for radionuclides in any of 177 tanks were reported in Agnew et al. 1997. The best-basis value for any one analyte may be either a model result or a sample or engineering assessment-based result if available. (No attempt was made to ratio or normalize model results for all 46 radionuclides when values for measured nuclides disagreed with the model.) For a discussion of typical error between model derived values and sample derived values, see Kupfer et al. (1997). 
HNF-SD-WM-ER-701 Rev. 0

Table 3-1. Best-Basis Inventory Estimates for Nonradioactive Components in Tank 241-BY-112 (Effective May 31, 1997). (2 sheets)

\begin{tabular}{|c|c|c|c|}
\hline 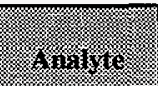 & 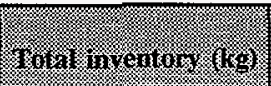 & 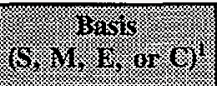 & (Cominevil: : : \\
\hline Al & 31,000 & $S$ & -- \\
\hline $\mathrm{Bi}$ & $<3,270$ & $S$ & $-\cdots$ \\
\hline $\mathrm{Ca}$ & $<3,270$ & $S$ & -- \\
\hline $\mathrm{Cl}$ & 2,110 & $\mathbf{S}$ & -- \\
\hline TIC as $\mathrm{CO}_{3}$ & 326,000 & $s$ & - \\
\hline $\mathrm{Cr}$ & 28,400 & $s$ & High throughout tank \\
\hline $\mathrm{F}$ & 15,100 & $S$ & - \\
\hline $\mathrm{Fe}$ & 4,760 & $s$ & -- \\
\hline $\mathrm{Hg}$ & 7.79 & $\mathbf{M}$ & -- \\
\hline $\mathrm{K}$ & 2,740 & $E$ & $\begin{array}{l}\text { Used average concentration from } \\
\text { other tanks in BY Farm }\end{array}$ \\
\hline $\mathrm{La}$ & 0.304 & $\mathbf{M}$ & --- \\
\hline Mn & $<469$ & $s$ & -- \\
\hline $\mathrm{Na}$ & 543,000 & $S$ & -- \\
\hline $\mathrm{Ni}$ & 7,750 & E & $\begin{array}{l}\text { Used average concentration from } \\
\text { other tanks in BY Farm. May be } \\
\text { too high as no actual data for ITS } \\
\text { tanks. }\end{array}$ \\
\hline $\mathrm{NO}_{2}$ & 37,000 & $\mathbf{S}$ & -- \\
\hline $\mathrm{NO}_{3}$ & 124,000 & $S$ & --- \\
\hline $\mathrm{OH}_{\text {TOTAL }}$ & 209,000 & C & Calculated from charge balance \\
\hline $\mathrm{Pb}$ & $<3,270$ & $s$ & -- \\
\hline $\mathrm{PO}_{4}$ & 26,700 & $s$ & --- \\
\hline $\mathbf{S i}$ & 3,910 & $S$ & - \\
\hline $\mathrm{SO}_{4}$ & 40,400 & $s$ & -- \\
\hline $\mathrm{Sr}$ & $<327$ & $s$ & - \\
\hline
\end{tabular}


Table 3-1. Best-Basis Inventory Estimates for Nonradioactive Components in Tank 241-BY-112 (Effective May 31, 1997). (2 sheets)

\begin{tabular}{|c|c|c|c|}
\hline 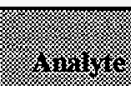 & 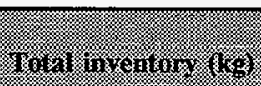 & 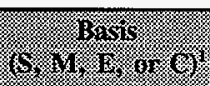 & 8ominent \\
\hline TOC & 13,600 & $S$ & -- \\
\hline $\mathrm{U}_{\text {TOTAL }}$ & $<16,500$ & $S$ & - \\
\hline $\mathrm{Zr}$ & $<327$ & $S$ & -- \\
\hline
\end{tabular}

Notes:

TIC $=$ total inorganic carbon

1S = sample-based, $\mathrm{M}=\mathrm{HDW}$ model-based, and $\mathrm{E}$ = engineering assessment-based, $\mathrm{C}=$ calculated by charge balance; includes oxides as hydroxides, not including $\mathrm{CO}_{3}, \mathrm{NO}_{3}, \mathrm{NO}_{2}, \mathrm{PO}_{4}$, $\mathrm{SO}_{4}$ and $\mathrm{SiO}_{3}$

Table 3-2. Best-Basis Inventory Estimates for Radioactive Components in Tank 241-BY-112 Decayed to January 1, 1994 (Effective May 31, 1997). (3 sheets)

\begin{tabular}{|c|c|c|c|}
\hline 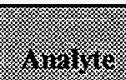 & 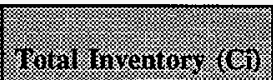 & (3) & ( S \\
\hline${ }^{3} \mathrm{H}$ & 140 & $\mathbf{M}$ & \\
\hline${ }^{14} \mathrm{C}$ & 36.4 & $\mathbf{M}$ & \\
\hline${ }^{59} \mathrm{Ni}$ & 3.97 & $\mathbf{M}$ & \\
\hline${ }^{60} \mathrm{Co}$ & 34.1 & $\mathbf{M}$ & \\
\hline${ }^{63} \mathrm{Ni}$ & 394 & $\mathbf{M}$ & \\
\hline${ }^{79} \mathrm{Se}$ & 3.06 & $\mathbf{M}$ & \\
\hline${ }^{90} \mathrm{Sr}$ & 133,000 & $\mathrm{E}$ & HDW estimate was 144,000 \\
\hline${ }^{90} \mathrm{Y}$ & 133,000 & $\mathrm{E}$ & Based on ${ }^{90} \mathrm{Sr}$ \\
\hline${ }^{93} \mathrm{Zr}$ & 14.7 & $\mathbf{M}$ & \\
\hline $93 \mathrm{~m} \mathrm{Nb}$ & 10.7 & $\mathbf{M}$ & \\
\hline${ }^{99} \mathrm{Tc}$ & 203 & $\mathbf{M}$ & \\
\hline${ }^{106} \mathrm{Ru}$ & 0.00680 & $\mathbf{M}$ & \\
\hline${ }^{113 m} \mathrm{Cd}$ & 78.1 & $\mathbf{M}$ & \\
\hline
\end{tabular}


Table 3-2. Best-Basis Inventory Estimates for Radioactive Components in Tank 241-BY-112 Decayed to January 1, 1994 (Effective May 31, 1997). (3 sheets)

\begin{tabular}{|c|c|c|c|}
\hline - and & 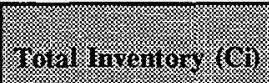 & (5. & 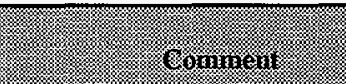 \\
\hline${ }^{125} \mathrm{Sb}$ & 153 & $\mathrm{M}$ & \\
\hline${ }^{126} \mathrm{Sn}$ & 4.57 & $\mathbf{M}$ & \\
\hline${ }^{129} \mathbf{T}$ & 0.393 & $\mathbf{M}$ & \\
\hline${ }^{134} \mathrm{Cs}$ & 1.66 & M & \\
\hline${ }^{137} \mathrm{Cs}$ & 189,000 & $\mathrm{E}$ & HDW estimate was 170,000 \\
\hline${ }^{137 m} \mathrm{Ba}$ & 179,000 & $\mathbf{E}$ & From ${ }^{137} \mathrm{Cs}$ \\
\hline${ }^{151} \mathrm{Sm}$ & 10,600 & $\mathbf{M}$ & \\
\hline${ }^{152} \mathrm{Eu}$ & 4.81 & $\mathbf{M}$ & \\
\hline${ }^{154} \mathrm{Eu}$ & 575 & $\mathbf{M}$ & \\
\hline${ }^{155} \mathrm{Eu}$ & 291 & $\mathbf{M}$ & \\
\hline${ }^{226} \mathrm{Ra}$ & $1.48 \mathrm{E}-04$ & $\mathbf{M}$ & \\
\hline${ }^{227} \mathrm{Ac}$ & 0.00208 & $\mathbf{M}$ & \\
\hline${ }^{228} \mathbf{R a}$ & 1.82 & $\mathbf{M}$ & \\
\hline${ }^{229} \mathrm{Th}$ & 0.0420 & $\mathbf{M}$ & \\
\hline${ }^{231} \mathrm{~Pa}$ & 0.0107 & $\mathbf{M}$ & \\
\hline${ }^{232} \mathrm{Th}$ & 0.0673 & $\mathbf{M}$ & \\
\hline${ }^{232} \mathrm{U}$ & 10.2 & $\mathbf{M}$ & \\
\hline${ }^{233} \mathrm{U}$ & 38.9 & $\mathbf{M}$ & \\
\hline${ }^{234} \mathrm{U}$ & 3.79 & $\mathbf{M}$ & \\
\hline${ }^{235} \mathrm{U}$ & 0.149 & $\mathbf{M}$ & \\
\hline${ }^{236} \mathrm{U}$ & 0.0983 & $\mathbf{M}$ & \\
\hline${ }^{237} \mathrm{~Np}$ & 0.680 & $\mathbf{M}$ & \\
\hline${ }^{238} \mathrm{Pu}$ & 2.71 & $\mathbf{M}$ & \\
\hline${ }^{238} \mathrm{U}$ & 6.82 & $\mathbf{M}$ & \\
\hline${ }^{239} \mathrm{Pu}$ & 97.2 & $\mathbf{M}$ & \\
\hline
\end{tabular}


Table 3-2. Best-Basis Inventory Estimates for Radioactive Components in

Tank 241-BY-112 Decayed to January 1, 1994 (Effective May 31, 1997). (3 sheets)

\begin{tabular}{|c|c|c|c|}
\hline (1) & M. & 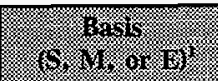 & (Cominent \\
\hline${ }^{240} \mathrm{Pu}$ & 16.7 & $\mathbf{M}$ & \\
\hline${ }^{241} \mathrm{Am}$ & 47.7 & $\mathbf{M}$ & \\
\hline${ }^{241} \mathrm{Pu}$ & 196 & $\mathbf{M}$ & \\
\hline${ }^{242} \mathrm{Cm}$ & 8.81E-04 & $M$ & \\
\hline${ }^{242} \mathrm{Pu}$ & $9.42 \mathrm{E}-04$ & $\mathbf{M}$ & \\
\hline${ }^{243} \mathrm{Am}$ & 0.00165 & $\mathbf{M}$ & \\
\hline${ }^{243} \mathrm{Cm}$ & $1.80 \mathrm{E}-05$ & $\mathrm{M}$ & \\
\hline${ }^{244} \mathrm{Cm}$ & $2.21 \mathrm{E}-04$ & M & \\
\hline
\end{tabular}

Note:

${ }^{1} \mathrm{~S}=$ sample-based, $\mathrm{M}=\mathrm{HDW}$ model-based, $\mathrm{E}=$ engineering assessment-based 


\subsection{RECOMMENDATIONS}

The TOC and DSC exceeded safety notification limits. However, the carbon is not associated with reactive compounds, and the DSC results were an artifact of the heterogeneity of the material. Headspace flammable gas measurements were less than 1 percent of the LFL. Therefore, the tank can be classified as "safe." Vapor samples were analyzed in accordance with the hazardous screening DQO. All analytes were below toxicity threshold limits. Vapor measurement also showed that the organic pool size is well below levels of concern for the organic solvents issue. The sampling and analysis activities performed for tank 241-BY-112 have met all requirements for the applicable DQOs.

Table 4-1 summarizes the status of the Project Hanford Management Contract (PHMC) TWRS Program Office review and acceptance of the sampling and analysis results reported in this tank characterization report. Column 1 lists all DQO issues required to be addressed by sampling and analysis. Column 2 indicates whether the requirements of the DQO were met by the sampling and analysis activities performed and is answered with a "yes" or a "no." Column 3 indicates concurrence and acceptance by the program in TWRS that is responsible for the DQO that the sampling and analysis activities performed adequately meet the needs of the DQO. A "yes" or "no" in column 3 indicates acceptance or disapproval of the sampling and analysis information in the TCR.

Table 4-1. Acceptance of Tank 241-BY-112 Sampling and Analysis.

\begin{tabular}{|c|c|c|}
\hline 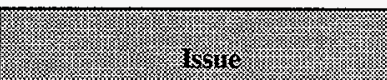 & $\begin{array}{l}\text { G Talliation: } \\
\text { Ienforned }\end{array}$ & 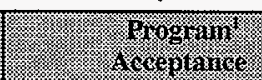 \\
\hline Safety screening DQO & Yes & Yes \\
\hline Hazardous vapor screening $\mathrm{DQO}$ & Yes & Issue Resolved \\
\hline Organic solvents & Yes & Yes \\
\hline
\end{tabular}

Note:

'PHMC TWRS Program Office

Table 4-2 summarizes the status of PHMC TWRS Program review and acceptance of the evaluations and other characterization information in this report. The evaluations specifically outlined in this report are the best-basis inventory evaluation and the evaluation to determine whether the tank is safe, conditionally safe, or unsafe. Column 1 lists the different evaluations performed in this report. Columns 2 and 3 are in the same format as Table 4-1. The manner in which concurrence and acceptance are summarized is also the same as that in Table 4-1. 
Table 4-2. Acceptance of Evaluation of Characterization Data and Information for Tank 241-BY-112.

\begin{tabular}{|c|c|c|}
\hline (3) & 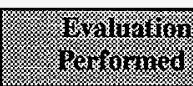 & 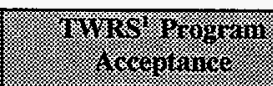 \\
\hline Safety categorization - Safe & Yes & Yes \\
\hline Hazardous vapor screening DQO & Yes & Issue resolved \\
\hline Organic solvents & No & Not decided \\
\hline
\end{tabular}

Note:

'PHMC TWRS Program Office 


\subsection{REFERENCES}

Agnew, S. F., J. Boyer, R. A. Corbin, T. B. Duran, J. R. Fitzpatrick, K. A. Jurgensen, T. P. Ortiz, and B. L. Young, 1997a, Hanford Tank Chemical and Radionuclide Inventories: HDW Model Rev. 4, LA-UR-96-3860, Los Alamos National Laboratory, Los Alamos, New Mexico.

Agnew, S. F., P. Baca, R. A. Corbin, T. B. Duran, K. A. Jurgensen, T. P. Prtiz and B. L. Young, 1997b, Waste Status and Transaction Record Summary, WSTRS, Rev. 4, LA-UR-97-311, Rev. 0, Los Alamos National Laboratory, Los Alamos, New Mexico.

Baldwin, J. H. and W. D. Winkelman, 1996, Tank 241-BY-112 Tank Characterization Plan, WHC-SD-WM-TP-281, Rev. 2, Westinghouse Hanford Company, Richland, Washington.

Cash, R. J., 1996, Scope Increase of Data Quality Objective to Support Resolution of the Organic Complexant Safety Issue, Rev. 2., (internal memorandum 79300-96-029 to S. J. Eberlein, July 12), Westinghouse Hanford Company, Richland, Washington.

Dukelow, G. T., J. W. Hunt, H. Babad, and J. E. Meacham, 1995, Tank Safety Screening Data Quality Objective, WHC-SD-WM-SP-004, Rev. 2, Westinghouse Hanford Company, Richland, Washington.

Ecology, EPA, and DOE, 1996, Hanford Federal Facility Agreement and Consent Order, as amended, Washington State Department of Ecology, U.S. Environmental Protection Agency, and U.S. Department of Energy, Olympia, Washington.

Hanlon, B. M., 1997, Waste Tank Summary Report for Month Ending February 28, 1997, HNF-EP-0182-107, Lockheed Martin Hanford Corp. for Fluor Daniel Hanford Inc., Richland, Washington.

Hewitt, E. R., 1996, Tank Waste Remediation System Resolution of Potentially Hazardous Vapor Issues, WHC-SD-TWR-RPT-001, Rev. 0, Westinghouse Hanford Company, Richland, Washington.

Hodgson, K. M., and M. D. LeClair, 1996, Work Plan for Defining a Standard Inventory Estimate for Wastes Stored in Hanford Site Underground Tanks, WHC-SD-WM-WP-311, Rev. 1, Lockheed Martin Hanford Corp. for Fluor Daniel Hanford Inc., Richland, Washington.

Kummerer, M., 1995, Heat Removal Characteristics of Waste Storage Tanks, WHC-SD-WM-SARR-010, Rev. 1, Westinghouse Hanford Company, Richland, Washington. 
Kupfer, M. J., A. L. Boldt, B. A. Higley, K. M. Hodgson, L. W. Shelton, and R. A. Watrous, S. L. Lambert, and D. E. Place, R. M. Orme , G. L. Borsheim, N. G. Colton, M. D. LeClair, R. T. Winward, and W. W. Schulz, 1997, Standard Inventories of Chemicals and Radionuclides in Hanford Site Tank Wastes, HNF-SD-WM-TI-740, Rev. 0, Lockheed Martin Hanford Corp. for Fluor Daniel Hanford Inc., Richland, Washington.

Nuzum, J. L., 1996, Safety Screening Analysis/Immediate Notification For Tank 241-BY-112, (letter RFSH-9656601 to Kathleen Hall, December 19), Rust Federal Services of Hanford Inc. for Fluor Daniel Hanford, Inc., Richland, Washington.

Nuzum, J. L., 1997, Tank 241-BY-112, Cores 174 and 177 Analytical Results for the Final Report, HNF-SD-WM-DP-229, Rev. 0, Rust Federal Services of Hanford Inc. for Fluor Daniel Hanford, Inc., Richland, Washington.

Osborne, J. W. and L. L. Buckley, 1995, Data Quality Objectives for Tank Hazardous Vapor Safety Screening, WHC-SD-WM-DQO-002, Rev. 2, Westinghouse Hanford Company, Richland, Washington.

Public Law 101-510, 1990, "Safety Measures for Waste Tanks at Hanford Nuclear Reservation," Section 3137 of National Defense Authorization Act for Fiscal Year 1991.

Smith, D. A., 1986, Single-Shell Tank Isolation Safety Analysis Report, WHC-SD-WM-SAR-006, Rev. 2, Westinghouse Hanford Company, Richland, Washington.

Watrous, R. A. and D. W. Wootan, 1997, Activity of Fuel Batches Processed Through Hanford Separations Plants, 1944 Through 1989, HNF-SD-WM-TI-794, Rev. 0, Lockheed Martin Hanford Corp. for Fluor Daniel Hanford Inc., Richland, Washington. 
HNF-SD-WM-ER-701 Rev. 0

APPENDIX A

HISTORICAL TANK INFORMATION

A-1 
This page intentionally left blank. 


\section{APPENDIX A}

\section{HISTORICAL TANK INFORMATION}

Appendix A describes tank 241-BY-112 based on historical information. Historical information includes any information about the fill history, waste types, surveillance, or modeling data about the tank. This information is necessary to provide a balanced assessment of the sampling and analytical results.

This appendix contains the following information:

- Section A1.0: Current status of the tank, including the current waste levels, and the stabilization and isolation status of the tank.

- Section A2.0: Information about the tank design.

- Section A3.0: Process knowledge about the tank, that is, the waste transfer history and the estimated contents of the tank based on modeling data.

- Section A4.0: Surveillance data for tank 241-BY-112, including surface-level readings, temperatures, and a description of the waste surface based on photographs.

- Section A5.0: References for Appendix A.

\section{A1.0 CURRENT TANK STATUS}

As of April 30, 1997, tank 241-BY-112 contained an estimated 1,100 kL (291 kgal) of waste classified as noncomplexed (Hanlon 1997). The solid waste volumes were estimated using a manual tape. The solid waste volume was last updated on April 28, 1982. Table A1-1 shows the amounts of various waste phases in the tank.

Tank 241-BY-112 is out of service as are all single-shell tanks. The tank was removed from the Ferrocyanide Watch List in September 1996. This tank is categorized as sound with interim stabilization and intrusion prevention completed (Hanlon 1997). The tank is passively ventilated. All monitoring systems were in compliance with documented standards as of April 30, 1997 (Hanion 1997). 
Table A1-1. Tank Contents Status Summary ${ }^{1}$.

\begin{tabular}{|l|l|}
\hline Total waste & Herie \\
\hline Supernatant liquid & $1,100(291)$ \\
\hline Sludge & $0(0)$ \\
\hline Saltcake & $20(5)$ \\
\hline Drainable interstitial liquid & $1,080(286)$ \\
\hline Drainable liquid remaining & $30(8)$ \\
\hline Pumpable liquid remaining & $30(8)$ \\
\hline
\end{tabular}

Note:

'Hanlon (1997)

\section{A2.0 TANK DESIGN AND BACKGROUND}

The 241-BY Tank Farm was constructed from 1948 to 1949 in the 200 East Area of the Hanford Site. The tank farm contains twelve 100 series tanks. These tanks have a capacity of $2,870 \mathrm{~kL}$ (758 kgal) and a diameter of $23 \mathrm{~m}(75 \mathrm{ft})$. Built according to the second generation design, the 241-BY Tank Farm was designed for nonboiling waste with a maximum fluid temperature of $104^{\circ} \mathrm{C}\left(220^{\circ} \mathrm{F}\right)$ (Leach and Stahl 1993). A cascade line $75 \mathrm{~mm}$ ( $3 \mathrm{in}$.) in diameter connects $241-\mathrm{BY}-112$ as last in a cascade series of three tanks beginning with tank 241-BY-110 (Hanlon 1997). Each tank in the cascade series is set $1 \mathrm{ft}$ lower in elevation than the preceding tank.

The tank has a dished bottom with a 1.2-m (4-ft) radius knuckle. Tank 241-BY-112 was designed with a primary mild steel liner (ASTM A283 Grade C) and a concrete dome with a number of risers. The tank is set on a reinforced concrete foundation. Three-ply asphalt waterproofing was applied over the foundation and steel tank. Two coats of primer were sprayed on all exposed interior tank surfaces. The tank ceiling dome was covered with three applications of magnesium zinc fluorosilicate wash. Lead flashing was used to protect the joint where the steel liner meets the concrete dome. Asbestos gaskets were used to seal the risers in the tank dome. The tank was waterproofed on the sides and top with tar and welded wire reinforced gunite (Rutherford 1948).

Tank 241-BY-112 has 24 risers according to the drawings and engineering change notices. The risers range in diameter from $100 \mathrm{~mm}$ (4 in.) to $1.1 \mathrm{~m}$ (42 in.). Table A2-1 shows numbers, diameters, and descriptions of the risers and the inlet and spare nozzles. 
Table A2-1. Tank 241-BY-112 Risers. 1, 2, 3, 4 (2 sheets)

\begin{tabular}{|c|c|c|}
\hline Yuming & 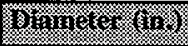 & 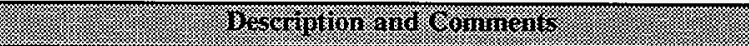 \\
\hline 1 & 4 & Breather filter, G1 housing \\
\hline 2 & 4 & Thermocouple tree \\
\hline 3 & 4 & Pit drain, weather covered \\
\hline 4 & 4 & Flange, below grade \\
\hline 5 & 4 & Flange, spare \\
\hline 6 & 12 & Not usable, weather covered \\
\hline 7 & 12 & Salt well pump and screen, weather covered \\
\hline 8 & 12 & Not usable, weather covered \\
\hline 9 & 42 & Cover plate, weather covered \\
\hline 10 & 42 & Adapter plate \\
\hline $10 \mathrm{~A}^{4}$ & $12^{5}$ & Observation port \\
\hline $10 B^{4}$ & $4^{5}$ & Flange \\
\hline 11 & 42 & Condenser, weather covered \\
\hline 12 & 42 & Adapter plate, weather covered \\
\hline $12 \mathrm{~A}$ & 4 & Blind flange \\
\hline 13 & 42 & Electric heater and air circulator, weather covered \\
\hline 14 & 6 & Flange, weather covered \\
\hline 15 & 6 & B-436 Liquid observation well \\
\hline 16 & 6 & Blind flange and 24 in. I.D. caisson cover \\
\hline 17 & 4 & Spare \\
\hline $18^{4}$ & 4 & Flange, spare [bench marked CEO-36923, December 12, 1986] \\
\hline 19 & 4 & Liquid-level reel \\
\hline $20^{4}$ & 4 & Flange \\
\hline $21^{4}$ & 4 & Spare \\
\hline N1 & 3 & Spare \\
\hline N2 & 3 & Spare \\
\hline
\end{tabular}


Table A2-1. Tank 241-BY-112 Risers. ${ }^{1,2,3,4}$ (2 sheets)

\begin{tabular}{|c|c|c|}
\hline Winner & Y) & 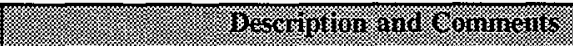 \\
\hline N3 & 3 & Spare \\
\hline N4 & 3 & Spare \\
\hline N5 & 3 & Inlet \\
\hline
\end{tabular}

Notes:

${ }^{1}$ Alstad (1993)

${ }^{2} \operatorname{Tran}(1993)$

${ }^{3}$ Drawing H-2-73256 (Vitro 1986)

${ }^{4}$ Denotes risers tentatively available for sampling (Lipnicki 1997)

SRisers $10 \mathrm{~A}$ and $10 \mathrm{~B}$ are on opposite sides of riser 10 than is listed on the drawing; also both were listed as 12 in. diameter in Lipnicki (1997) and Alstad (1993).

Figure A2-1 shows the riser and nozzle configuration. Risers 18, 20, and $21(100 \mathrm{~mm}$ [4 in.] in diameter), and riser $10 \mathrm{~A}$ (300 $\mathrm{mm}$ [12 in.] in diameter) are available for sampling (Lipnicki 1997). Figure A2-2 is a cross section showing the approximate waste level and a schematic of the tank equipment. 


\section{HNF-SD-WM-ER-701 Rev. 0}

Figure A2-1. Riser Configuration for Tank 241-BY-112.

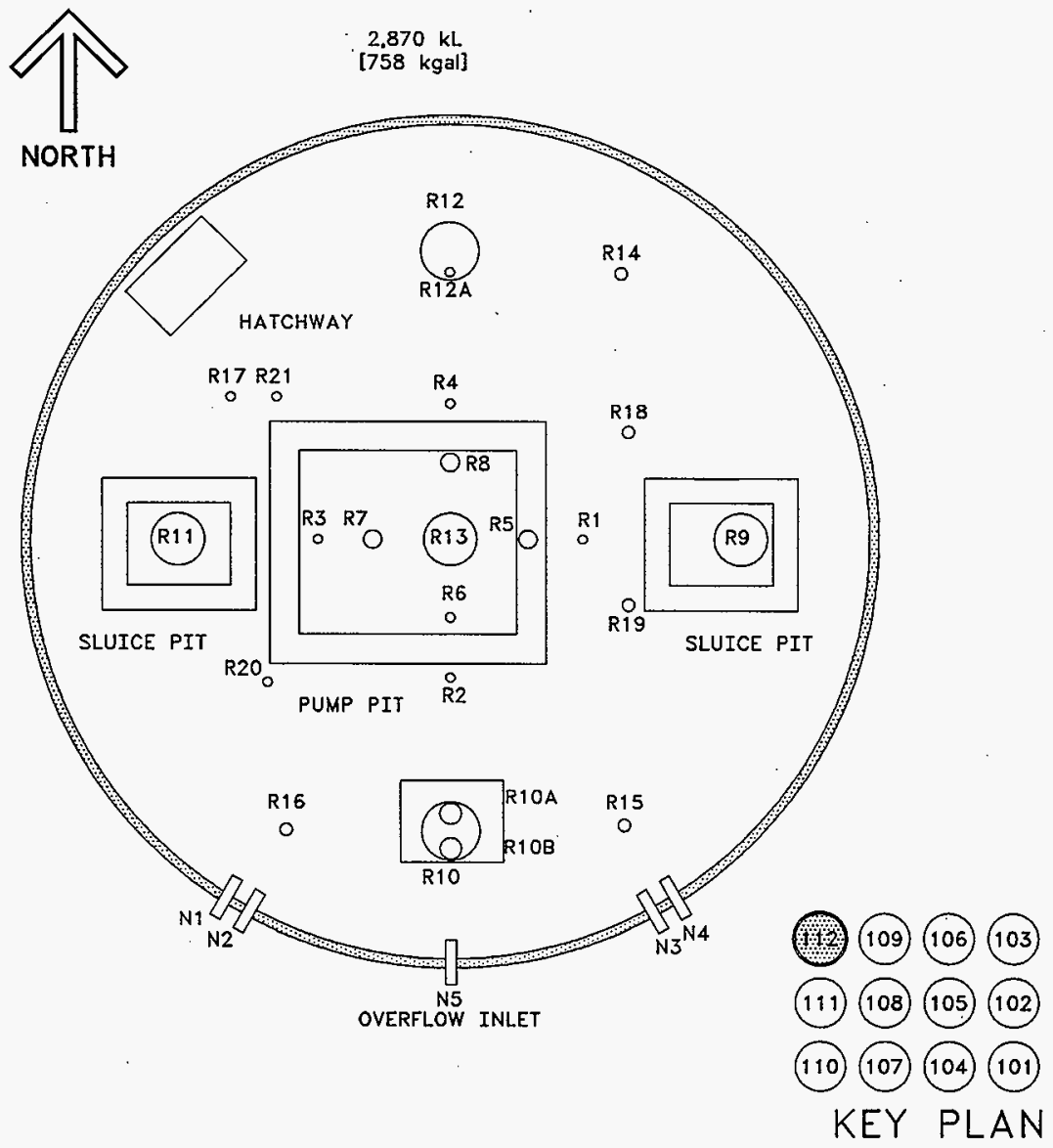




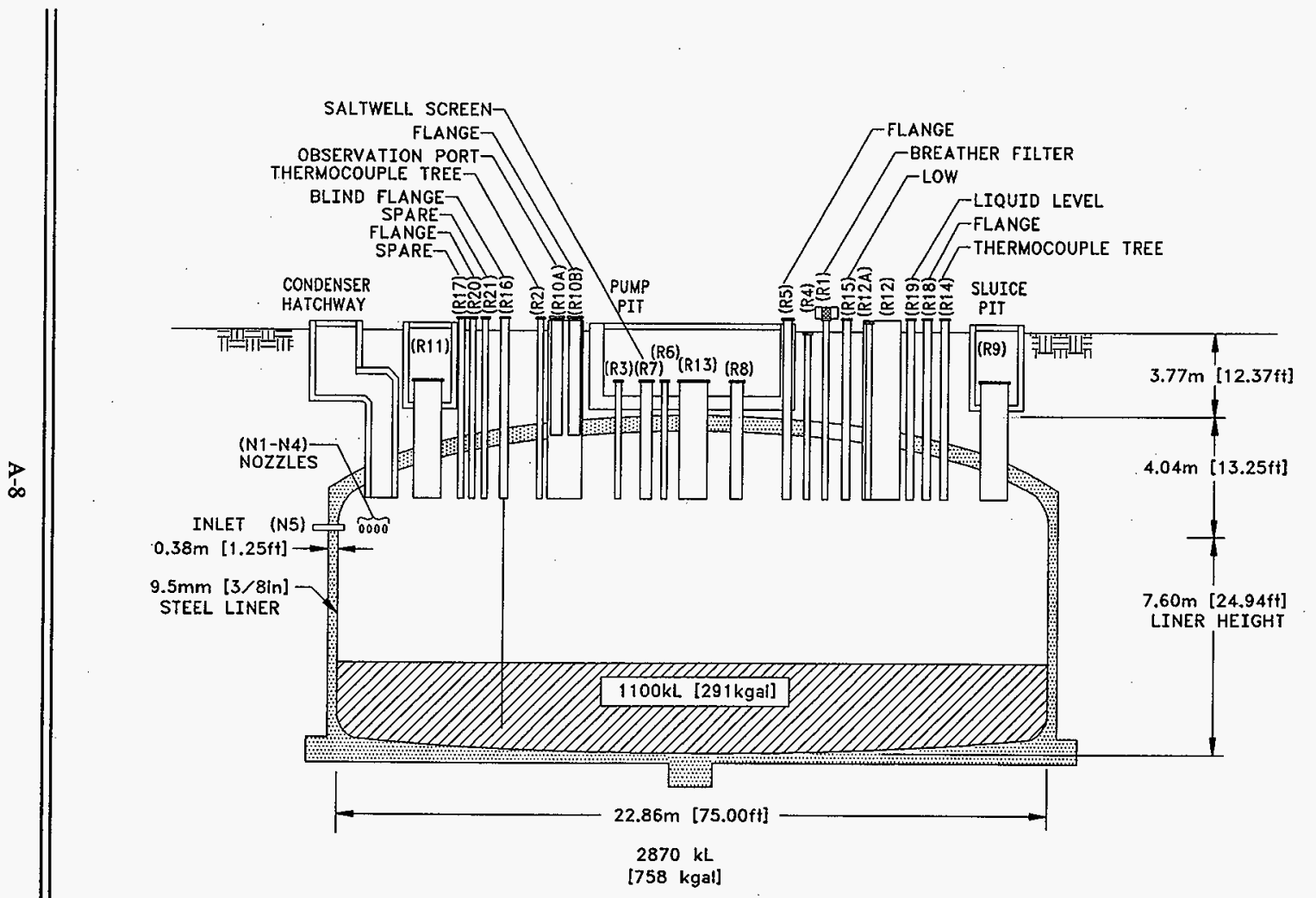




\section{A3.0 PROCESS KNOWLEDGE}

The sections below 1) provide information about the history of the major waste transfers that involved tank 241-BY-112, 2) describe the process wastes that were transferred, and 3) estimate the current tank contents based on the waste transfer history.

\section{A3.1 WASTE TRANSFER HISTORY}

Table A3-1 summarizes the waste transfer history of tank 241-BY-112 (Agnew et al. 1997b). Tank 241-BY-112 first received metal waste from B Plant during the second quarter of 1951. During the first and fourth quarters of 1952, the tank received metal waste through the cascade from tank 241-BY-111. During the second, third, and fourth quarters of 1952, tank 241-BY-112 again received metal waste from B Plant.

Metal waste sludge was sent to tank 241-BY-111 during the first quarter of 1955 . In the second quarter of 1955 , the tank received metal waste from B plant. During 1956, tank 241-BY-112 received supernatant from tanks 241-BY-106, 241-BY-107, and 241-BY-108. Ferrocyanide sludge was received during the second quarter of 1957 , and supernatant was sent to the B-028 and B-029 cribs. During the third and fourth quarters of 1957, tank 241-BY-112 received supernatant from tank 241-C-105.

The tank remained static until the second and third quarters of 1965 when supernatant was sent to tanks 241-BY-109, 241-BY-101, and 241-BY-103. The tank received supernatant from tanks 241-C-102 and tank 241-BY-111 from the third quarter of 1965 to the third quarter of 1966. During the fourth quarter of 1967, tank 241-BY-112 received cladding waste from PUREX.

In 1966, a heater was placed in the tank to cause evaporation (ITS2). During late 1967 and early 1968, tank 241-BY-112 received waste from tanks $241-C-110$ and $241-B-102$. From the first quarter of 1968 to the second quarter of 1996, the tank received waste from the first in-tank solidification unit (ITS1) tank 241-BY-102 as well as tanks 241-BY-111, 241-BY108, 241-BY-109, 241-BY-110, 241-BY-107, 241-BY-105, 241-BY-106, 241-BY-103, 241-BY-104, 241-B-106, 241-BY-102, 241-B-111, 241-BX-110, 241-BX-111, 241-B-112, 241-B-101, 241-B-105. During this same time, waste was transferred from the tank to tanks 241-B-110, 241-BX-101, 241-BX-104, 241-BY-111, 241-C-102, 241-BY-108, 241-BY-109, 241-B-111, 241-BY-110, 241-BY-107, 241-BY-104, 241-BY-106, 241-B-111, 241-BY-105, 241-BY-102, 241-B-105, 241-BX-110, 241-BY-103, 241-B-112, 241-B-101, 241-BX-106, 241-B-109 and 241-BY-105.

Table A3-1 lists the estimated amount of liquid evaporated during the ITS process from 1968 to 1975 .

Interstitial liquor was salt well pumped to tank 241-AW-102 in the third quarter of 1982. 
Table A3-1. Tank 241-BY-112 Major Waste Transfers. ${ }^{1,2}$ (3 sheets)

\begin{tabular}{|c|c|c|c|c|c|}
\hline \multirow{2}{*}{4 Sintinger } & \multirow{2}{*}{ Iranisfer } & \multirow[b]{2}{*}{ Vaste 1 1 por } & \multirow{2}{*}{ 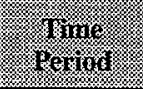 } & \multicolumn{2}{|c|}{ 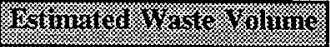 } \\
\hline & & & & I: & $\sqrt{1}, 8 \mathrm{kgal}$ \\
\hline B Plant & & MW1 and MW2 & 1951-1952 & 477 & 126 \\
\hline \multirow[t]{2}{*}{ 241-BY-111 } & & MW2 & 1952 & 988 & 261 \\
\hline & 241-BY-111 & SL & 1955 & $-1,480$ & -390 \\
\hline B Plant & & MW & 1955 & 8 & 2 \\
\hline $\begin{array}{l}241-\mathrm{BY}-106 \\
241-\mathrm{BY}-107 \\
241-\mathrm{BY}-108\end{array}$ & & SU & 1956 & 2,640 & 698 \\
\hline \multirow[t]{2}{*}{ U Plant } & & PFeCN2 & 1957 & 651 & 172 \\
\hline & Cribs B-028, B-029 & SU & 1957 & $-2,590$ & -685 \\
\hline \multirow[t]{2}{*}{$241-\mathrm{C}-105$} & & SU & 1957 & 2,173 & 574 \\
\hline & \begin{tabular}{|l|}
$241-\mathrm{BY}-109$ \\
$241-\mathrm{BY}-101$ \\
$241-\mathrm{BY}-103$
\end{tabular} & SU & 1965 & $-2,770$ & -732 \\
\hline $\begin{array}{l}241-C-102 \\
241-B Y-111\end{array}$ & & SU & 1965,1966 & 2,730 & 721 \\
\hline PUREX & & CWP2 & 1967 & 20 & 4 \\
\hline Cell 23 & & EVAP & 1967,1968 & 2,820 & 746 \\
\hline \multirow[t]{2}{*}{ 241-BY-102 } & & $\mathrm{CW}$ & 1968 & 12,530 & 3,311 \\
\hline & \begin{tabular}{|l|}
$241-B-110$ \\
$241-B X-101$ \\
$241-B X-104$ \\
$241-C-102$
\end{tabular} & $\mathrm{CW}$ & 1968 & $-3,202$ & -846 \\
\hline \multirow[t]{3}{*}{$241-B Y-108$} & & $S U$ & $1968-1971$ & 3,510 & 926 \\
\hline & 241-BY-108 & $\overline{\mathrm{EB}}$ & $1968-1971$ & $-2,650$ & -700 \\
\hline & Evaporated & BYCOND & $1968-1975$ & $-93,830$ & $-24,790$ \\
\hline \multirow[t]{3}{*}{$\begin{array}{l}241-\mathrm{BY}-111 \\
241-\mathrm{BY}-109\end{array}$} & & SU & $1968-1976$ & 75,049 & 19,826 \\
\hline & $\begin{array}{l}241-B Y-111 \\
241-B Y-109\end{array}$ & EB & $1968-1976$ & $-25,038$ & $-6,614$ \\
\hline & 241-B-111 & $\mathrm{EB}$ & 1969,1970 & -350 & -92 \\
\hline \multirow[t]{2}{*}{ 241-BY-107 } & & $\overline{S U}$ & $1969-1974$ & 3,600 & 952 \\
\hline & 241-BY-107 & $E B$ & $1969-1974$ & -784 & -207 \\
\hline
\end{tabular}


HNF-SD-WM-ER-701 Rev. 0

Table A3-1. Tank 241-BY-112 Major Waste Transfers., 2 (3 sheets)

\begin{tabular}{|c|c|c|c|c|c|}
\hline \multirow{2}{*}{ than } & \multirow{2}{*}{ 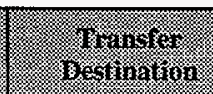 } & \multirow[b]{2}{*}{ Waste Vyos } & \multirow{2}{*}{ Meninge: } & \multicolumn{2}{|c|}{ 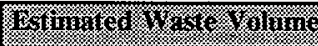 } \\
\hline & & & & III. & 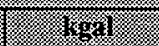 \\
\hline \multirow[t]{2}{*}{$241-B Y-110$} & & SU & $1969-1976$ & 3,770 & 996 \\
\hline & 241-BY-110 & $\mathrm{EB}$ & $1969-1976$ & -1810 & -479 \\
\hline \multirow{2}{*}{$\begin{array}{l}241-\mathrm{BY}-104 \\
\text { 241-BY-105 } \\
\text { 241-BY-106 }\end{array}$} & & SU & $1970-1974$ & 18,630 & 4,923 \\
\hline & \begin{tabular}{|l|}
$241-\mathrm{BY}-104$ \\
$241-\mathrm{BY}-105$ \\
$241-\mathrm{BY}-106$
\end{tabular} & EB & $1970-1974$ & $-3,440$ & -910 \\
\hline $241-\mathrm{B}-106$ & & BNW & 1971,1972 & 140 & 38 \\
\hline \multirow[t]{2}{*}{ 241-BY-103 } & & SU & $1971-1973$ & 9,285 & 2,453 \\
\hline & 241-BY-103 & EB & $1971-1973$ & -95 & -25 \\
\hline \multirow[t]{2}{*}{\begin{tabular}{|l|}
$241-\mathrm{BY}-102$ \\
$241-\mathrm{BX}-111$
\end{tabular}} & & SU & $1971-1974$ & 1,518 & 401 \\
\hline & $\begin{array}{l}241-\mathrm{BY}-102 \\
241-\mathrm{BX}-111\end{array}$ & EB & 1971-1974 & $-2,680$ & -709 \\
\hline \multirow[t]{2}{*}{$\begin{array}{l}241-\mathrm{B}-111 \\
241-\mathrm{B}-112\end{array}$} & & $\mathrm{~EB}, \mathrm{IX}$ & 1972 & 130 & 34 \\
\hline & $241-\mathrm{B}-105$ & EB & 1972,1973 & -939 & -248 \\
\hline \multirow[t]{4}{*}{ 241-BX-110 } & & EB & $1972-1973$ & 2,250 & 595 \\
\hline & 241-BX-110 & SU & $1972-1973$ & -190 & -50 \\
\hline & $241-\mathrm{B}-112$ & EB & 1973 & -965 & -255 \\
\hline & 241-B-101 & SU & 1974 & -270 & -72 \\
\hline \multirow[t]{2}{*}{ 241-B-101 } & & SU & 1974,1976 & 462 & 122 \\
\hline & 241-BX-106 & SU & $\begin{array}{l}1974,1975 \\
1976\end{array}$ & -829 & -219 \\
\hline $241-B-105$ & & SU & 1975 & 749 & 198 \\
\hline
\end{tabular}


Table A3-1. Tank 241-BY-112 Major Waste Transfers. ${ }^{1,2}$ (3 sheets)

\begin{tabular}{|c|c|c|c|c|c|}
\hline \multirow{2}{*}{ 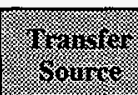 } & \multirow{2}{*}{ 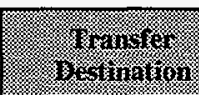 } & \multirow[b]{2}{*}{ 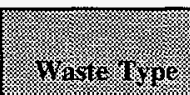 } & \multirow{2}{*}{$\begin{array}{l}\text { gini } \\
\text { Ieriod }\end{array}$} & \multicolumn{2}{|c|}{ 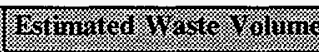 } \\
\hline & & & & 12 & 1) \\
\hline & $\begin{array}{l}\text { 241-BX-105 } \\
241-\mathrm{B}-109\end{array}$ & $\mathrm{SU}$ & 1975,1976 & $-1,510$ & -400 \\
\hline $\begin{array}{l}\text { Misc. } \\
\text { Sources }\end{array}$ & & Water & $\begin{array}{l}1971,1974, \\
1975\end{array}$ & 2,210 & 560 \\
\hline & 241-AW-102 & EVAP & 1982 & -72 & -19 \\
\hline
\end{tabular}

Notes:

$\begin{array}{lll}\text { BNW } & = & \text { Battelle Northwest Laboratory waste } \\ \text { BYCOND } & = & \text { Liquid condensed by in-tank evaporators and sent to cribs } \\ \text { CW } & = & \text { Cladding waste } \\ \text { CWP2 } & = & \text { Cladding waste from PUREX } \\ \text { EB } & = & \text { Evaporator bottoms } \\ \text { EVAP } & = & \text { Ion exchange waste } \\ \text { IX } & = & \begin{array}{l}\text { Metal waste from the bismuth phosphate process (which extracted plutonium) } \\ \text { containing all of the uranium, approximately } 90 \text { percent of the original } \\ \text { fission product activity, and approximately } 1 \text { percent of the product. "Metal* }\end{array} \\ \text { MW } & \text { was the code word for plutonium. } \\ \text { PFeCN2 } & =\quad \text { Ferrocyanide sludge produced by scavenging uranium recovery supernatant. } \\ \text { SL } & =\quad \text { Sludge } \\ \text { SU } & =\quad \text { Supernatant }\end{array}$

${ }^{1}$ Agnew et al. (1997)

${ }^{2}$ Because only major waste transfers are listed, the sum of the transfers will not equal the current volume of waste in the tank. 


\section{A3.2 HISTORICAL ESTIMATION OF TANK CONTENTS}

The historical transfer used for this estimate are from the following sources:

- Waste Status and Transaction Record Summary for the Northeast Quadrant (WSTRS) (Agnew et al. 1997b). WSTRS is a tank-by-tank quarterly summary spreadsheet of waste transactions.

- Hanford Tank Chemical and Radionuclide Inventories: HDW Model Rev. 4 (Agnew et al. 1997a) This document contains the Hanford defined waste (HDW) list, the supernatant mixing model (SMM), and the tank layer model (TLM).

- Historical Tank Content Estimate for the Northeast Quadrant of the Hanford 200 East Area (HTCE) (Brevick et al. 1996). This document compiles and summarizes much of the process history, design, and technical information regarding the underground waste storage tanks in the northeast quadrant of the 200 areas.

- Tank layer model (TLM) The TLM defines the sludge and saltcake layers in each tank using waste composition and waste transfer information.

- Supernatant mixing model (SMM). This is a subroutine within the HDW model that calculates the volume and composition of certain supernatant blends and concentrates.

Using these records, the TLM defines the sludge and saltcake layers in each tank. The SMM uses information from both the WSTRS and the TLM to describe the supernatants and concentrates in each tank. Together, the WSTRS, TLM, and SMM determine each tank's inventory estimate. These model predictions are considered estimates that require further evaluation using analytical data.

Based on the TLM and SMM, tank 241-BY-112 contains a top layer of 1,071 kL (283 kgal) BY saltcake above a layer of $27 \mathrm{~kL}$ (6 kgal) ferrocyanide sludge (PFeCN2) over a bottom layer of $7.6 \mathrm{~kL}$ ( $2 \mathrm{kgal}$ ) of MW. Figure A3-1 is a graph representing the estimated waste type and volume for each waste layer.

The MW (bottom waste layer) should contain, from highest concentration above one weight percent, the following major constituents: uranium, hydroxide, sodium, carbonate, and phosphate. Constituents contained in this layer above a tenth of a weight percent are sulfate, iron, nitrate, and calcium.

The PFeCN2 layer is estimated to contain, from highest concentration above one weight percent, the following constituents: nitrate, sodium, bismuth, hydroxide, iron, phosphate, 
uranium, ferrocyanate, carbonate, and sulfate. Constituents contained in this layer above a tenth of a weight percent are calcium, nitrite, nickel, fluoride, chloride, and silicate.

The BY saltcake layer is estimated to contain, from highest concentration above one weight percent, the following constituents: nitrate, sodium, hydroxide, nitrite, aluminum, carbonate, and sulfate. Constituents contained in this layer above a tenth of a weight percent are phosphate, uranium, dibutyl phosphate, citrate, chloride, calcium, chromium, silicate, acetate, and butanol. Table A3-2 shows an estimate of the expected waste constituents and their concentrations.

Figure A3-1. Tank Layer Model.

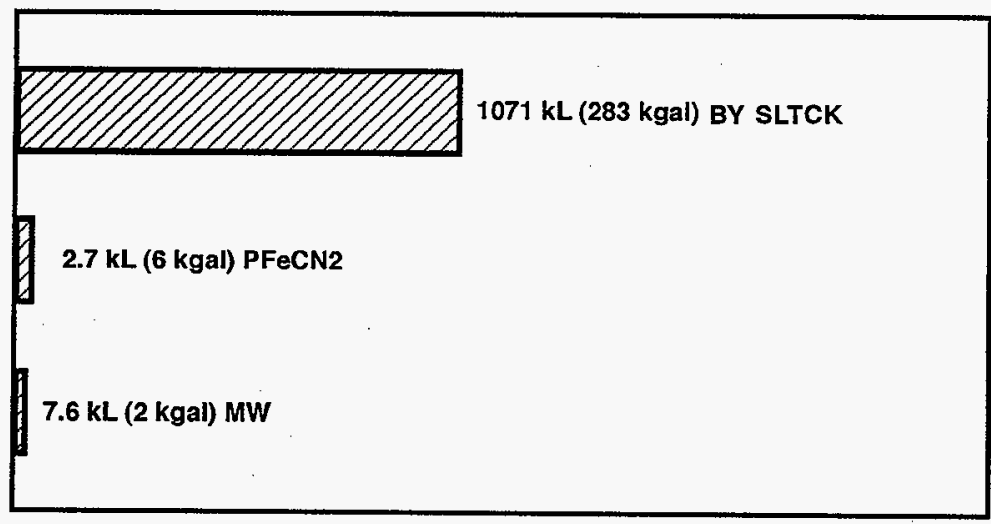


Table A3-2. Historical Tank Inventory Estimate. (6 sheets)

\begin{tabular}{|c|c|c|c|c|c|c|c|}
\hline 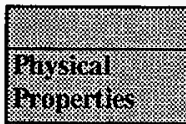 & & & 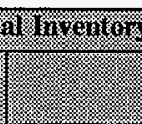 & 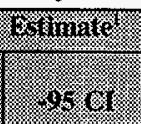 & 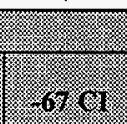 & 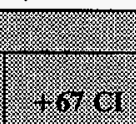 & 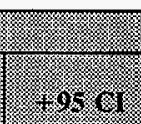 \\
\hline Total waste & $\begin{array}{l}1.80 \mathrm{E}+06 \\
(\mathrm{~kg})\end{array}$ & $(291 \mathrm{kgal})$ & -- & -- & - & -- & -- \\
\hline Heat load & $1.77(\mathrm{~kW})$ & $-\cdots$ & - & 1.13 & 1.49 & 1.96 & 2.06 \\
\hline Bulk density & $1.63\left(\mathrm{~g} / \mathrm{cm}^{3}\right)$ & -- & - & 1.33 & 1.48 & 1.75 & 1.87 \\
\hline Water $\mathrm{wt} \%{ }^{2,3}$ & 36.1 & $-\cdots$ & -- & 16.9 & 26.3 & 49.0 & 60.5 \\
\hline $\begin{array}{l}\text { TOC wt\% } \\
\text { carbon }\end{array}$ & 0.440 & $-\cdots$ & -- & 0.348 & 0.420 & 0.466 & 0.475 \\
\hline 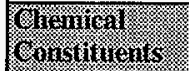 & (n) & 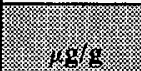 & $=18$ & 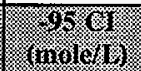 & (nivitert & (nofies) & $\begin{array}{c}95 \\
\text { mold }\end{array}$ \\
\hline $\mathrm{Na}^{+}$ & 13.0 & $1.83 \mathrm{E}+05$ & $3.30 \mathrm{E}+05$ & 6.89 & 9.80 & 15.6 & 18.5 \\
\hline$\overline{\mathrm{Al}^{3+}}$ & 2.06 & $3.39 \mathrm{E}+04$ & $6.11 \mathrm{E}+04$ & 0.886 & 1.27 & 3.01 & 3.92 \\
\hline $\mathrm{Fe}^{3+}$ (total $\mathrm{Fe}$ ) & $4.18 \mathrm{E}-02$ & $1.43 \mathrm{E}+03$ & $2.57 \mathrm{E}+03$ & $3.23 \mathrm{E}-02$ & $3.69 \mathrm{E}-02$ & $4.66 \mathrm{E}-02$ & $5.13 \mathrm{E}-02$ \\
\hline $\mathrm{Cr}^{3+}$ & $5.35 \mathrm{E}-02$ & $1.70 \mathrm{E}+03$ & $3.07 \mathrm{E}+03$ & $4.27 \mathrm{E}-02$ & $4.84 \mathrm{E}-02$ & $5.56 \mathrm{E}-02$ & $5.76 \mathrm{E}-02$ \\
\hline$\overline{\mathrm{Bi}^{3+}}$ & $6.75 \mathrm{E}-03$ & 864 & $1.55 \mathrm{E}+03$ & $6.36 \mathrm{E}-03$ & $6.55 \mathrm{E}-03$ & $6.95 \mathrm{E}-03$ & $7.14 \mathrm{E}-03$ \\
\hline $\mathrm{La}^{3+}$ & $1.99 \mathrm{E}-06$ & 0.169 & 0.304 & $1.65 \mathrm{E}-06$ & $1.86 \mathrm{E}-06$ & $2.07 \mathrm{E}-06$ & $2.03 \mathrm{E}-06$ \\
\hline $\mathrm{Hg}^{2+}$ & $3.52 \mathrm{E}-05$ & 4.33 & 7.79 & $3.17 \mathrm{E}-05$ & $3.34 \mathrm{E}-05$ & $3.70 \mathrm{E}-05$ & $3.88 \mathrm{E}-05$ \\
\hline $\begin{array}{l}\mathrm{Zr} \mathrm{(as} \\
\left.\mathrm{ZrO}(\mathrm{OH})_{2}\right)\end{array}$ & $3.30 \mathrm{E}-05$ & 1.84 & 3.32 & $2.72 \mathrm{E}-05$ & $3.01 \mathrm{E}-05$ & $3.42 \mathrm{E}-05$ & $3.42 \mathrm{E}-05$ \\
\hline $\mathrm{Pb}^{2+}$ & $5.52 \mathrm{E}-03$ & 700 & $1.26 \mathrm{E}+03$ & $3.00 \mathrm{E}-03$ & $4.23 \mathrm{E}-03$ & $6.80 \mathrm{E}-03$ & $8.03 \mathrm{E}-03$ \\
\hline $\mathrm{Ni}^{2+}$ & $1.58 \mathrm{E}-02$ & 569 & $1.02 \mathrm{E}+03$ & $1.13 \mathrm{E}-02$ & $1.37 \mathrm{E}-02$ & $1.69 \mathrm{E}-02$ & $1.70 \mathrm{E}-02$ \\
\hline
\end{tabular}


Table A3-2. Historical Tank Inventory Estimate. (6 sheets)

\begin{tabular}{|c|c|c|c|c|c|c|c|}
\hline & & m. & all froromin & EThinas & & & \\
\hline 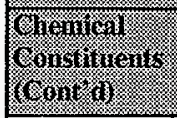 & iniser: & 188 & (2. & flus & 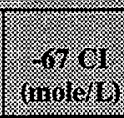 & (170107. & 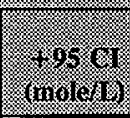 \\
\hline $\mathrm{Sr}^{2+}$ & 0 & 0 & 0 & 0 & 0 & 0 & 0 \\
\hline $\mathrm{Mn}^{4+}$ & $3.15 \mathrm{E}-03$ & 106 & 191 & $2.32 \mathrm{E}-03$ & $2.73 \mathrm{E}-03$ & $3.58 \mathrm{E}-03$ & $3.98 \mathrm{E}-03$ \\
\hline $\mathrm{Ca}^{2+}$ & $7.77 \mathrm{E}-02$ & $1.91 \mathrm{E}+03$ & $3.43 \mathrm{E}+03$ & $5.03 \mathrm{E}-02$ & $6.37 \mathrm{E}-02$ & $9.14 \mathrm{E}-02$ & 0.104 \\
\hline $\mathrm{K}+$ & $3.89 \mathrm{E}-02$ & 932 & $1.68 \mathrm{E}+03$ & $2.82 \mathrm{E}-02$ & $3.41 \mathrm{E}-02$ & $4.30 \mathrm{E}-02$ & $4.01 \mathrm{E}-02$ \\
\hline $\mathrm{OH}^{-}$ & 9.63 & $1.00 \mathrm{E}+05$ & $1.80 \mathrm{E}+05$ & 4.70 & 6.42 & 13.5 & 17.1 \\
\hline $\mathrm{NO}_{3}{ }^{-}$ & 6.58 & $2.50 \mathrm{E}+05$ & $4.50 \mathrm{E}+05$ & 3.01 & 4.85 & 7.69 & 8.72 \\
\hline $\mathrm{NO}_{2}^{-}$ & 1.65 & $4.65 \mathrm{E}+04$ & $8.37 \mathrm{E}+04$ & 0.965 & 1.33 & 1.89 & 2.63 \\
\hline $\mathrm{CO}_{3}^{2-}$ & 0.510 & $1.87 \mathrm{E}+04$ & $3.37 \mathrm{E}+04$ & 0.358 & 0.406 & 0.613 & 0.668 \\
\hline $\mathrm{PO}_{4}^{3-}$ & $7.68 \mathrm{E}-02$ & $4.46 \mathrm{E}+03$ & $8.03 \mathrm{E}+03$ & $6.50 \mathrm{E}-02$ & 7.31E-02 & $7.83 \mathrm{E}-02$ & 8.21E-02 \\
\hline $\mathrm{SO}_{4}^{2-}$ & 0.190 & $1.12 \mathrm{E}+04$ & $2.01 E+04$ & 0.110 & 0.151 & 0.224 & 0.313 \\
\hline $\mathrm{Si}$ (as $\mathrm{SiO}_{3}{ }^{2-}$ ) & $7.58 \mathrm{E}-02$ & $1.30 \mathrm{E}+03$ & $2.35 \mathrm{E}+03$ & $4.54 \mathrm{E}-02$ & $6.18 \mathrm{E}-02$ & $8.74 \mathrm{E}-02$ & $9.63 \mathrm{E}-02$ \\
\hline $\mathrm{F}^{*}$ & $5.64 \mathrm{E}-02$ & 657 & $1.18 \mathrm{E}+03$ & $4.85 \mathrm{E}-02$ & $5.33 \mathrm{E}-02$ & $6.39 \mathrm{E}-02$ & $8.70 \mathrm{E}-02$ \\
\hline $\mathrm{Cl}^{-}$ & 0.129 & $2.79 \mathrm{E}+03$ & $5.03 \mathrm{E}+03$ & $6.96 \mathrm{E}-02$ & $9.86 \mathrm{E}-02$ & 0.135 & 0.135 \\
\hline $\mathrm{C}_{6} \mathrm{H}_{5} \mathrm{O}_{7}^{3-}$ & $2.32 \mathrm{E}-02$ & $2.69 \mathrm{E}+03$ & $4.84 \mathrm{E}+03$ & $1.92 \mathrm{E}-02$ & $2.26 \mathrm{E}-02$ & $2.37 \mathrm{E}-02$ & $2.37 \mathrm{E}-02$ \\
\hline EDTA $^{4}$ & $5.22 \mathrm{E}-03$ & 920 & $1.66 \mathrm{E}+03$ & $4.60 \mathrm{E}-03$ & $5.03 \mathrm{E}-03$ & $5.31 \mathrm{E}-03$ & $5.33 \mathrm{E}-03$ \\
\hline HEDTA $^{3 \cdot}$ & $7.04 \mathrm{E}-04$ & 118 & 213 & $2.13 \mathrm{E}-04$ & $4.79 \mathrm{E}-04$ & $8.85 \mathrm{E}-04$ & $9.00 \mathrm{E}-04$ \\
\hline glycolate & $1.64 \mathrm{E}-02$ & 752 & $1.35 \mathrm{E}+03$ & $8.28 \mathrm{E}-03$ & $1.28 \mathrm{E}-02$ & $1.92 \mathrm{E}-02$ & $1.87 \mathrm{E}-02$ \\
\hline acetate & $3.10 \mathrm{E}-02$ & $1.12 \mathrm{E}+03$ & $2.02 \mathrm{E}+03$ & $2.70 \mathrm{E}-02$ & $3.06 \mathrm{E}-02$ & $3.13 \mathrm{E}-02$ & $3.17 \mathrm{E}-02$ \\
\hline oxalate $^{2-}$ & $2.61 \mathrm{E}-06$ & 0.140 & 0.253 & $1.91 \mathrm{E}-06$ & $2.37 \mathrm{E}-06$ & $2.84 \mathrm{E}-06$ & $2.98 \mathrm{E}-06$ \\
\hline
\end{tabular}


Table A3-2. Historical Tank Inventory Estimate. (6 sheets)

\begin{tabular}{|c|c|c|c|c|c|c|c|}
\hline \multicolumn{8}{|c|}{ 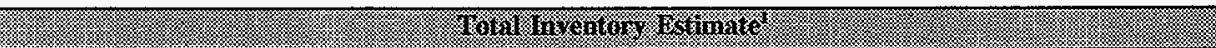 } \\
\hline 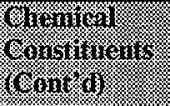 & 4 & $\sqrt{.89}$ & 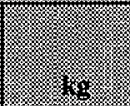 & 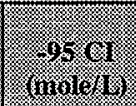 & 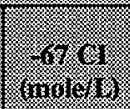 & 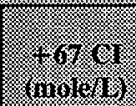 & throf \\
\hline$\overline{\mathrm{DBP}}$ & $2.47 \mathrm{E}-02$ & $3.18 \mathrm{E}+03$ & $5.72 \mathrm{E}+03$ & $2.13 \mathrm{E}-02$ & $2.36 \mathrm{E}-02$ & $2.53 \mathrm{E}-02$ & $2.52 \mathrm{E}-02$ \\
\hline Butanol & $2.47 \mathrm{E}-02$ & $1.12 \mathrm{E}+03$ & $2.02 \mathrm{E}+03$ & $2.13 \mathrm{E}-02$ & $2.36 \mathrm{E}-02$ & $2.53 \mathrm{E}-02$ & $2.52 \mathrm{E}-02$ \\
\hline $\mathrm{NH}_{3}$ & $1.92 \mathrm{E}-02$ & 199 & 359 & $1.25 \mathrm{E}-02$ & $1.54 \mathrm{E}-02$ & $2.31 \mathrm{E}-02$ & $2.45 \mathrm{E}-02$ \\
\hline $\mathrm{Fe}(\mathrm{CN})_{6}^{4}$ & $1.61 \mathrm{E}-03$ & 267 & 480 & $1.61 \mathrm{E}-03$ & $1.61 \mathrm{E}-03$ & $1.61 \mathrm{E}-03$ & $1.61 \mathrm{E}-03$ \\
\hline $\begin{array}{l}\text { frojologicul } \\
\text { Constinent. }\end{array}$ & (111) & 10.18 & @ & 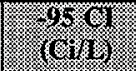 & 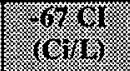 & (1) & 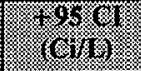 \\
\hline${ }^{3} \mathrm{H}$ & $1.27 \mathrm{E}-04$ & $7.77 \mathrm{E}-02$ & 140 & $6.09 \mathrm{E}-08$ & $6.09 \mathrm{E}-08$ & $1.28 \mathrm{E}-04$ & $1.30 \mathrm{E}-04$ \\
\hline${ }^{14} \mathrm{C}$ & $3.31 \mathrm{E}-05$ & $2.02 \mathrm{E}-02$ & 36.4 & $2.63 \mathrm{E}-08$ & 2.63E-08 & $3.43 \mathrm{E}-05$ & $3.54 \mathrm{E}-05$ \\
\hline${ }^{59} \mathrm{Ni}$ & $3.61 \mathrm{E}-06$ & $2.21 \mathrm{E}-03$ & 3.97 & $8.31 \mathrm{E}-08$ & $8.31 \mathrm{E}-08$ & $3.76 \mathrm{E}-06$ & $3.91 \mathrm{E}-06$ \\
\hline${ }^{63} \mathrm{Ni}$ & $3.57 \mathrm{E}-04$ & 0.219 & 394 & $7.49 \mathrm{E}-06$ & $7.49 \mathrm{E}-06$ & 3.73E-04 & $3.87 \mathrm{E}-04$ \\
\hline${ }^{60} \mathrm{Co}$ & $3.09 \mathrm{E}-05$ & $1.89 \mathrm{E}-02$ & 34.1 & $2.05 \mathrm{E}-09$ & $2.05 \mathrm{E}-09$ & $3.12 \mathrm{E}-05$ & $3.16 \mathrm{E}-05$ \\
\hline${ }^{79} \mathrm{Se}$ & $2.77 \mathrm{E}-06$ & $1.70 \mathrm{E}-03$ & 3.06 & $2.08 \mathrm{E}-09$ & $2.08 \mathrm{E}-09$ & $3.40 \mathrm{E}-06$ & $3.98 \mathrm{E}-06$ \\
\hline${ }^{90} \mathrm{Sr}$ & 0.131 & 80.1 & $1.44 \mathrm{E}+05$ & 0.104 & 0.123 & 0.139 & 0.146 \\
\hline${ }^{90} \mathrm{Y}$ & 0.131 & 80.1 & $1.44 \mathrm{E}+05$ & $7.01 \mathrm{E}-03$ & $7.01 \mathrm{E}-03$ & 0.139 & 0.146 \\
\hline${ }^{93} \mathrm{Zr}$ & $1.34 \mathrm{E}-05$ & $8.20 \mathrm{E}-03$ & 14.7 & $9.88 \mathrm{E}-09$ & $9.88 \mathrm{E}-09$ & $1.65 \mathrm{E}-05$ & $1.93 \mathrm{E}-05$ \\
\hline${ }^{93 m} \mathrm{Nb}$ & $9.68 \mathrm{E}-06$ & $5.93 \mathrm{E}-03$ & 10.7 & $8.38 \mathrm{E}-09$ & $8.38 \mathrm{E}-09$ & 1.19E-05 & $1.38 \mathrm{E}-05$ \\
\hline${ }^{99} \mathrm{Tc}$ & $1.84 \mathrm{E}-04$ & 0.113 & 203 & $9.50 \mathrm{E}-05$ & $1.44 \mathrm{E}-04$ & $2.15 \mathrm{E}-04$ & $2.10 \mathrm{E}-04$ \\
\hline${ }^{106} \mathrm{Ru}$ & $6.17 \mathrm{E}-09$ & $3.78 \mathrm{E}-06$ & $6.80 \mathrm{E}-03$ & $7.26 \mathrm{E}-16$ & $7.26 \mathrm{E}-16$ & $6.74 \mathrm{E}-09$ & $7.21 \mathrm{E}-09$ \\
\hline${ }^{113 m} \mathrm{Cd}$ & $7.09 \mathrm{E}-05$ & $4.34 \mathrm{E}-02$ & 78.1 & $2.32 \mathrm{E}-08$ & $2.32 \mathrm{E}-08$ & $8.95 \mathrm{E}-05$ & $1.06 \mathrm{E}-04$ \\
\hline${ }^{122} \mathrm{Sb}$ & $1.39 \mathrm{E}-04$ & $8.49 \mathrm{E}-02$ & 153 & $1.77 \mathrm{E}-09$ & $1.77 \mathrm{E}-09$ & $1.40 \mathrm{E}-04$ & $1.41 \mathrm{E}-04$ \\
\hline
\end{tabular}


Table A3-2. Historical Tank Inventory Estimate. (6 sheets)

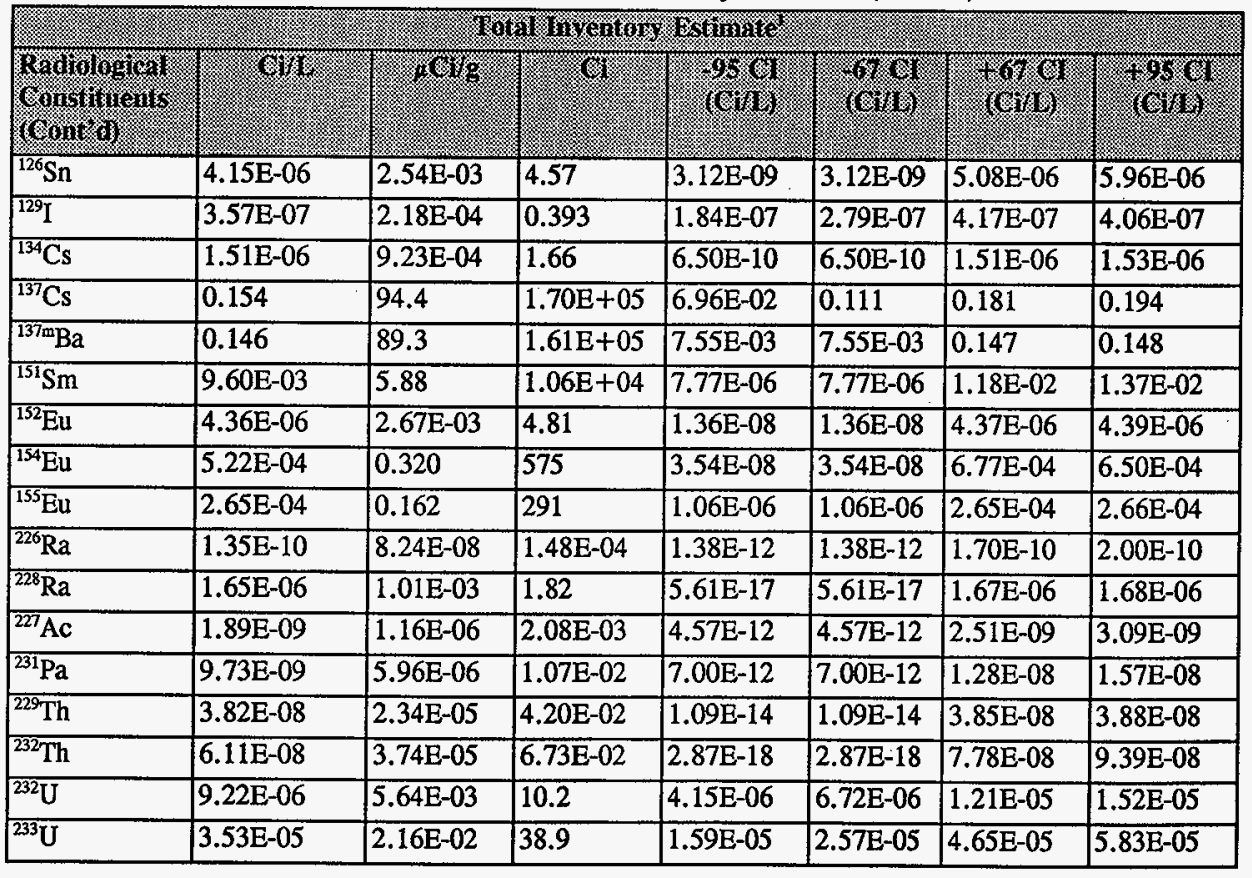


Table A3-2. Historical Tank Inventory Estimate. (6 sheets)

\begin{tabular}{|c|c|c|c|c|c|c|c|}
\hline & & & 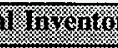 & fotinine & & & \\
\hline 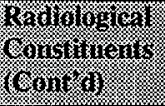 & (4) & $f_{12}$ & (2) & (9) & 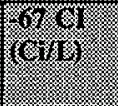 & (69) & 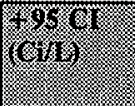 \\
\hline $234 \mathrm{U}$ & $3.45 \mathrm{E}-06$ & $2.11 \mathrm{E}-03$ & 3.79 & $2.87 \mathrm{E}-06$ & $3.33 \mathrm{E}-06$ & $3.56 \mathrm{E}-06$ & $3.66 \mathrm{E}-06$ \\
\hline${ }^{335} \mathrm{U}$ & $1.35 \mathrm{E}-07$ & $8.27 \mathrm{E}-05$ & 0.149 & $1.17 \mathrm{E}-07$ & $1.31 \mathrm{E}-07$ & $1.40 \mathrm{E}-07$ & $1.44 \mathrm{E}-07$ \\
\hline${ }^{3{ }^{36}} \mathrm{U}$ & $8.92 \mathrm{E}-08$ & $5.46 \mathrm{E}-05$ & $9.83 \mathrm{E}-02$ & 7.48E-08 & $8.52 \mathrm{E}-08$ & 9.33E-08 & 9.73E-08 \\
\hline${ }^{38} \mathbf{U}$ & $6.19 \mathrm{E}-06$ & $3.79 \mathrm{E}-03$ & 6.82 & $5.68 \mathrm{E}-06$ & $6.09 \mathrm{E}-06$ & $6.29 \mathrm{E}-06$ & $6.39 \mathrm{E}-06$ \\
\hline${ }^{237} \mathrm{~Np}$ & $6.18 \mathrm{E}-07$ & $3.78 \mathrm{E}-04$ & 0.680 & $3.35 \mathrm{E}-07$ & $4.92 \mathrm{E}-07$ & $7.17 \mathrm{E}-07$ & $6.94 \mathrm{E}-07$ \\
\hline${ }^{38} \mathrm{Pu}$ & $2.46 \mathrm{E}-06$ & $1.51 \mathrm{E}-03$ & 2.71 & $1.10 \mathrm{E}-06$ & $1.78 \mathrm{E}-06$ & $3.15 \mathrm{E}-06$ & $3.82 \mathrm{E}-06$ \\
\hline${ }^{39} \mathrm{Pu}$ & $8.83 \mathrm{E}-05$ & $5.40 \mathrm{E}-02$ & 97.2 & $4.25 \mathrm{E}-05$ & $6.57 \mathrm{E}-05$ & $1.11 \mathrm{E}-04$ & $1.32 \mathrm{E}-04$ \\
\hline${ }^{40} \mathrm{Pu}$ & $1.51 \mathrm{E}-05$ & $9.26 \mathrm{E}-03$ & 16.7 & $7,13 \mathrm{E}-06$ & $1.11 \mathrm{E}-05$ & $1.91 \mathrm{E}-05$ & $2.30 \mathrm{E}-05$ \\
\hline${ }^{4{ }^{41}} \mathrm{Pu}$ & $1.78 \mathrm{E}-04$ & 0.109 & 196 & $7.94 \mathrm{E}-05$ & $1.28 \mathrm{E}-04$ & $2.27 \mathrm{E}-04$ & $2.75 \mathrm{E}-04$ \\
\hline${ }^{842} \mathrm{Pu}$ & $8.55 \mathrm{E}-10$ & $5.23 \mathrm{E}-07$ & $9.42 \mathrm{E}-04$ & $3.84 \mathrm{E}-10$ & $6.16 \mathrm{E}-10$ & $1.09 \mathrm{E}-09$ & \begin{tabular}{|l}
$1.33 \mathrm{E}-09$ \\
\end{tabular} \\
\hline $241 \mathrm{Am}$ & $4.33 \mathrm{E}-05$ & $2.65 \mathrm{E}-02$ & 47.7 & $1.51 \mathrm{E}-05$ & $2.89 \mathrm{E}-05$ & $\overline{5.70 \mathrm{E}-05}$ & $6.76 \mathrm{E}-05$ \\
\hline 243 Am & $1.50 \mathrm{E}-09$ & $9.17 \mathrm{E}-07$ & $1.65 \mathrm{E}-03$ & $4.62 \mathrm{E}-10$ & $9.57 \mathrm{E}-10$ & $2.04 \mathrm{E}-09$ & $2.48 \mathrm{E}-09$ \\
\hline${ }^{242} \mathrm{Cm}$ & $8.00 \mathrm{E}-10$ & $4.89 \mathrm{E}-07$ & $8.81 \mathrm{E}-04$ & $2.42 \mathrm{E}-10$ & $2.42 \mathrm{E}-10$ & $8.05 \mathrm{E}-10$ & $8.10 \mathrm{E}-10$ \\
\hline 年3 $\mathrm{Cm}$ & 1.63E-11 & $1.00 \mathrm{E}-08$ & $1.80 \mathrm{E}-05$ & $4.96 \mathrm{E}-12$ & $4.96 \mathrm{E}-12$ & $1.64 \mathrm{E}-11$ & $1.66 \mathrm{E}-11$ \\
\hline${ }^{244} \mathrm{Cm}$ & $2.01 \mathrm{E}-10$ & $1.23 \mathrm{E}-07$ & $2.21 \mathrm{E}-04$ & $2.43 \mathrm{E}-12$ & $2.43 \mathrm{E}-12$ & $2.02 \mathrm{E}-10$ & $2.03 \mathrm{E}-10$ \\
\hline
\end{tabular}


Table A3-2. Historical Tank Inventory Estimate. (6 sheets)

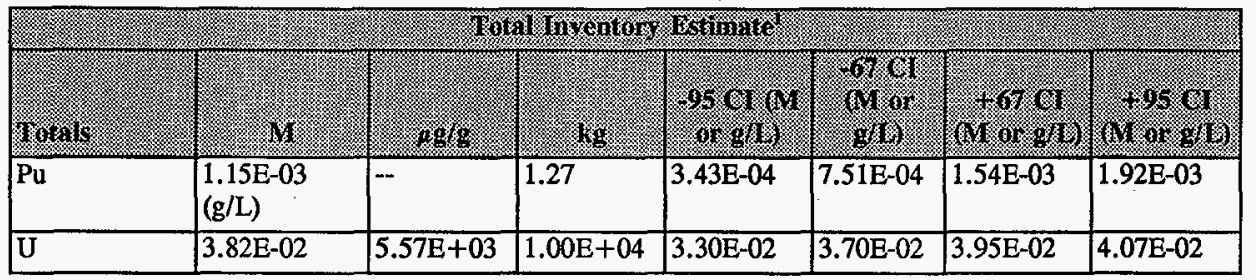

Notes:

${ }^{1}$ Unknowns in tank solids inventory are assigned by TLM.

${ }^{2}$ Water $w t \%$ derived from the difference of density and total dissolved species.

${ }^{3}$ Volume average for density, mass average water wt $\%$ and TOC wt $\%$ carbon.

CI $=$ confidence interval 


\section{A4.0 SURVEILLANCE DATA}

Tank 241-BY-112 surveillance includes surface level measurements (liquid and solid) and temperature monitoring inside the tank (waste and headspace). The data provide the basis for determining tank integrity.

Liquid-level measurements may indicate whether there is a major leak from a tank. Solid surface-level measurements can indicate physical changes and consistency in the solid layers such as those caused by gas generation and retention.

\section{A4.1 SURFACE-LEVEL READINGS}

The waste surface level for tank 241-BY-112 is measured by a manual tape located in riser 19. On October 3, 1996, the waste surface level was $2.87 \mathrm{~m}$ (113 in.) as measured by the manual tape. Figure A4-1 is a level history graph of the volume measurements.

\section{A4.2 DRY WELL READINGS}

Tank 241-BY-112 has 7 dry wells. No dry well had readings greater than the 50 counts per second above background radiation.

\section{A4.3 INTERNAL TANK TEMPERATURES}

Tank 241-BY-112 has a thermocouple tree located in risers 2. The Surveillance Analysis Computer System (SACS) has data only from the thermocouple tree located in riser 2, with 6 thermocouples to monitor the waste temperature. The elevations of all thermocouples on this tree are available. Temperature data, recorded from August 1974 through December 1996, were obtained from the SACS database (LMHC 1997).

The average temperature was $28.4^{\circ} \mathrm{C}\left(83.2^{\circ} \mathrm{F}\right)$, the minimum was $5^{\circ} \mathrm{C}\left(41^{\circ} \mathrm{F}\right)$, and the maximum was $62.2^{\circ} \mathrm{C}\left(144^{\circ} \mathrm{F}\right)$. The average temperature of the SACS data over the last year (December 1995 through December 1996) was $28.1^{\circ} \mathrm{C}\left(82.6^{\circ} \mathrm{F}\right)$, the minimum was $19^{\circ} \mathrm{C}\left(66^{\circ} \mathrm{F}\right)$, and the maximum was $32.3^{\circ} \mathrm{C}\left(90.1^{\circ} \mathrm{F}\right)$. The maximum temperature on December 18,1996 was $31.6^{\circ} \mathrm{C}\left(88.9^{\circ} \mathrm{F}\right)$ on thermocouple 3 (in the waste) and the minimum was $22.3^{\circ} \mathrm{C}\left(72.1^{\circ} \mathrm{F}\right.$ ) on thermocouple 6 (in the headspace). Figure A4-2 is a graph of the weekly high temperatures. Brevick et al. (1996b) plots the individual thermocouple readings. 


\section{A4.4 TANK 241-BY-112 PHOTOGRAPHS}

The April 1988 photographic montage of the interior of tank 241-BY-112 (Brevick et al. 1996b) șhows a white dry surface of saltcake. Various pieces of equipment, for example, risers and identifiable debris have been labeled in the photograph. The waste level has not changed since the photographs were taken; therefore, this photographic montage should accurately represent the current appearance of the tank's waste. 
Figure A4-1. Tank 241-BY-112 Level History.

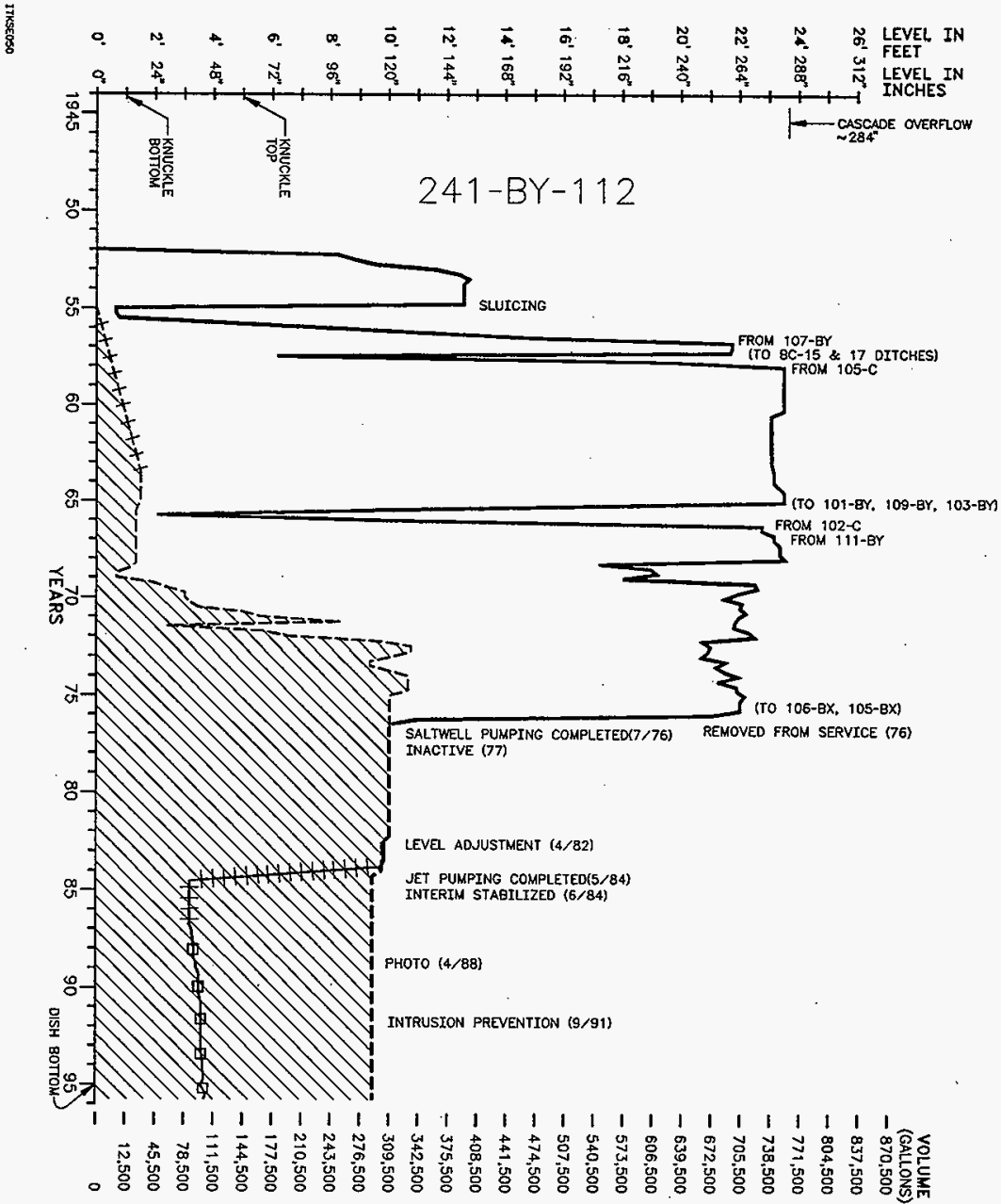


Figure A4-2. Tank 241-BY-112 Weekly High Temperature Plot.

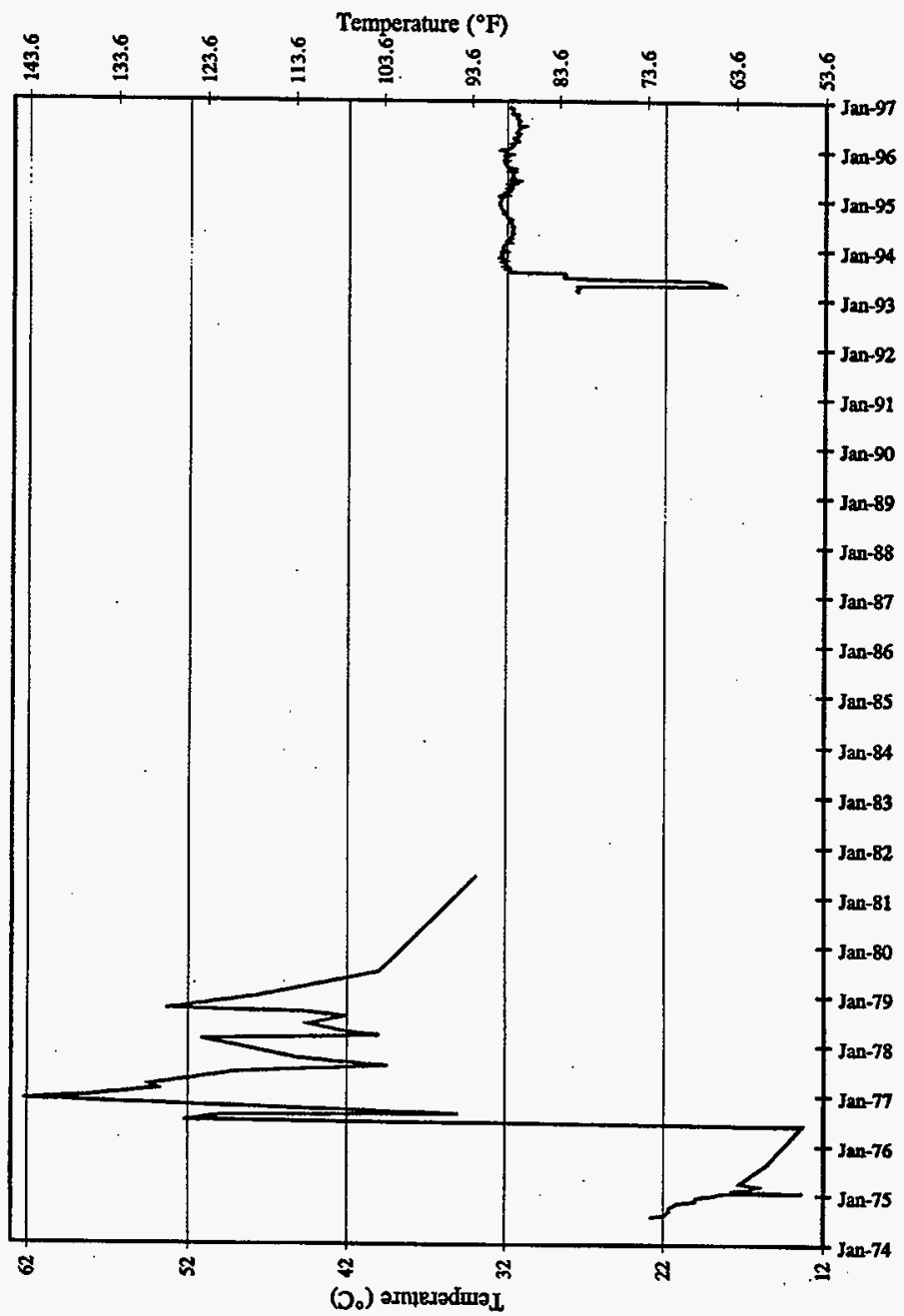




\section{A5.0 APPENDIX A REFERENCES}

Alstad, A. T., 1993, Riser Configuration Document for Single-Shell Waste Tanks, WHC-SD-RE-TI-053, Rev. 9, Westinghouse Hanford Company, Richland, Washington.

Agnew, S. F., J. Boyer, R. A. Corbin, T. B. Duran, J. R. Fitzpatrick, K. A. Jurgensen, T. P. Ortiz, and B. L. Young, 1997a, Hanford Tank Chemical and Radionuclide Inventories: HDW Model Rev. 3, LA-UR-96-3860, Rev. 4, Los Alamos National Laboratory, Los Alamos, New Mexico.

Agnew, S. F., P. Baca, R. A. Corbin, T. B. Duran, and K. A. Jurgensen, 1997b, Waste Status and Transaction Record Summary, WSTRS, Rev. 4, LA-UR-97-311, Rev. 0, Los Alamos National Laboratory, Los Alamos, New Mexico.

Brevick, C. H., L. A. Gaddis, and J. W. Funk, 1996a, Historical Tank Content Estimate for the Northeast Quadrant of the Hanford 200 East Area, WHC-SD-WM-ER-349, Rev. 1A, ICF Kaiser Hanford Company, Richland, Washington.

Brevick, C. H., L. A. Gaddis, and J. W. Funk, 1996b, Supporting Document for the Historical Tank Content Estimate for BY Tank Farm, WHC-SD-WM-ER-308, Rev. 1A, ICF Kaiser Hanford Company, Richland, Washington.

Hanlon, B. M., 1997, Waste Tank Summary Report for Month Ending April 30, 1997, WHC-EP-0182-109, Lockheed Martin Hanford Corp. for Fluor Daniel, Inc., Richland, Washington.

Leach, C. E., and S. M. Stahl, 1997, Hanford Site Tank Farm Facilities Interim Safety Basis, WHC-SD-WM-ISB-001, Rev. 0, Westinghouse Hanford Company, Richland, Washington.

Lipnicki, J., 1997, Waste Tank Risers Available for Sampling, WHC-SD-WM-TI-710, Rev. 4, Lockheed Martin Hanford Corp. for Fluor Daniel Hanford, Inc., Richland, Washington.

LMHC, 1997, SACS: Surveillance Analysis Computer System. In: SQL Server/Visual Basic [mainframe], Available: Hanford Local Area Network, Lockheed Martin Hanford Corp., Richland, Washington.

Rutherford, M. J., 1948, Specifications for Construction of Additional Waste Storage Facilities, 200 East Area, Bldg. 241-BY, HW-3783, General Electric Company, Richland, Washington. 
Tran, T. T., 1993, Thermocouple Status Single-Shell and Double-Shell Waste Tanks, WHC-SD-WM-TI-553, Rev. 0, Westinghouse Hanford Company, Richland, Washington.

Vitro, 1986, Piping Waste Tank Isolation 241-BY-112, Drawing H-2-73256, Rev. 2, Vitro Engineering Corporation, Richland, Washington. 
APPENDIX B

SAMPLING OF TANK 241-BY-112 
This page intentionally left blank. 


\section{APPENDIX B}

\section{SAMPLING OF TANK 241-BY-112}

Appendix B provides sampling and analysis information for each known sampling event for tank 241-BY-112 and assesses push mode sample results.

- Section B1.0: Tank Sampling Overview

- Section B2.0: Sampling Events

- Section B3.0: Assessment of Characterization Results

- Section B4.0: References for Appendix B

Future sampling of tank 241-BY-112 will be appended to the above list.

\section{B1.0 TANK SAMPLING OVERVIEW}

This section describes the sampling and analysis events for tank 241-BY-112. Push mode samples were taken to satisfy the requirements of the Tank Safety Screening Data Quality Objective (Dukelow et al. 1995). The sampling and analyses were performed in accordance with the Tank 241-BY-112 Push Mode Sampling and Analysis Plan (Baldwin 1997). For. further information about the sampling and analysis procedures, refer to the Tank Characterization Reference Guide (DeLorenzo et al. 1994).

Headspace and vapor samples were collected from tank 241-BY-112. Sample collection and analysis were performed as directed by Tank 241-BY-112 Tank Characterization Plan (Homi 1994).

\section{B2.0 SAMPLING EVENTS}

This section describes sampling events. Tables B2-6 through B2-63 show analytical results. The analytical results used to characterize current tank contents were the 1994 vapor sample and 1996 push mode core sample. Section 2.4 provides historical sample results. 


\section{B2.1 1996 PUSH MODE SAMPLING EVENT}

Two push mode samples were collected from tank 241-BY-112. Core 174, composed of 6 segments, was obtained on October 2 and 3, 1996, from riser number 18. Core 177, composed of 6 segments, was obtained on October 7, 1996, from riser 21. Core 174 was received at the 222-S Laboratory on October 29, 1996 and extruded on November 4, 1996. Core 177 was received by the 222-S Laboratory on October 31, 1996, and extruded on November 5 to 8, 1996. Core sampling was used because of the depth of the waste and the expectation that a full vertical profile of the waste would be obtained.

Table 1-1 provides data on the segment recoveries from the cores. Fach segment is $48.3 \mathrm{~cm}$ (19 in.) long, $2.54 \mathrm{~cm}\left(1 \mathrm{in}\right.$.) in diameter, and has a maximum volume of $244.5 \mathrm{~cm}^{3}$ $\left(14.9\right.$ in. $\left.^{3}\right)$. Segment recoveries were identified as percent recovered based on the theoretical volume of the sampler.

A vertical profile was used to satisfy the safety screening DQO (Dukelow et al. 1995). Safety screening analyses included: total alpha to determine criticality, DSC to determine the fuel energy value, and thermogravimetric analysis (TGA) to determine the total moisture content. In addition, combustible gas meter readings in the tank headspace were performed to measure flammability.

Table B2-1 summarizes the sampling and analytical requirements from the safety screening DQO.

Table B2-1. Integrated Data Quality Objective Requirements for Tank 241-BY-112.

\begin{tabular}{|c|c|c|c|}
\hline Similngis: & 40 & Rermirangury & 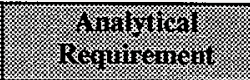 \\
\hline $\begin{array}{l}\text { Push mode core } \\
\text { sampling }\end{array}$ & $\begin{array}{l}\text { Safety screening } \\
\text { - Energetics } \\
\text { - Moisture content } \\
\text { - Total alpha } \\
\text { - Flammable gas }\end{array}$ & $\begin{array}{l}\text { Core samples from a } \\
\text { minimum of two risers } \\
\text { separated radially to the } \\
\text { maximum extent possible. } \\
\text { Combustible gas measurement }\end{array}$ & $\begin{array}{l}\text { Flammability } \\
\text { energetics, moisture } \\
\text { total alpha, density, } \\
\text { anions, cations, } \\
\text { radionuclides, total } \\
\text { organic carbon }\end{array}$ \\
\hline \multirow[t]{2}{*}{ Vapor sampling } & Hazardous vapor & \multirow{2}{*}{$\begin{array}{l}\text { Steel canisters, triple sorbent } \\
\text { traps, sorbent trap systems }\end{array}$} & \multirow{2}{*}{$\begin{array}{l}\text { Flammable gas } \\
\text { Organic vapors } \\
\text { Permanent gases }\end{array}$} \\
\hline & $\begin{array}{l}\text { Organic solvents } \\
\text { (DOE-RL } 1996 \text { and } \\
\text { Cash 1996b) }\end{array}$ & & \\
\hline
\end{tabular}

Note:

'Baldwin (1997) 


\section{B2.1.1 Sample Handling}

\section{Core 174}

Six push mode core segments were removed from tank 241-BY-112 riser 18 on October 2 and 3, 1996. All segments were received by the 222-S Laboratory on October 29, 1996. Table B2-2 gives the subsampling scheme and sample description.

\section{Core 177}

Six push mode core segments were removed from tank $241-\mathrm{BY}-112$ riser 21 on October 7, 1996. All segments were received by the 222-S Laboratory on October 31, 1996.

Table B2-3 gives the subsampling scheme and sample description.

\section{Field Blank}

The field blank sample was prepared on October 8, 1996 and received by the 222-S Laboratory on October 15, 1996. The material recovered was treated as a drainable liquid as directed by Baldwin (1997).

\section{Hydrostatic Head Fluid Blank}

There is no indication of the use of hydrostatic head fluid in procuring these samples.

A blank was not provided to the 222-S Laboratory. 
Table B2-2. Sample Receipt and Extrusion Information for Tank 241-BY-112, Core 174.

\begin{tabular}{|c|c|c|c|c|c|}
\hline 86 & S(1) & 8ximinimis & 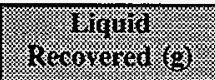 & 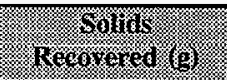 & 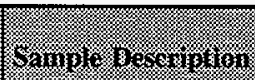 \\
\hline \multirow[t]{6}{*}{18} & 1 & 5.0 & 0.0 & 62.0--Lower half & $\begin{array}{l}\text { Solids were yellow } \\
\text { to brown and } \\
\text { resembled a dry } \\
\text { salt. }\end{array}$ \\
\hline & 2 & 6.0 & 0.0 & 103.8--Lower half & $\begin{array}{l}\text { Solids were brown } \\
\text { and resembled a dry } \\
\text { salt. }\end{array}$ \\
\hline & 3 & 6.0 & 0.0 & 84.5--Lower half & $\begin{array}{l}\text { Solids were brown } \\
\text { and resembled a dry } \\
\text { salt. }\end{array}$ \\
\hline & 4 & $7: 0$ & 0.0 & 164.5--Lower half & $\begin{array}{l}\text { Solids were brown } \\
\text { to green and } \\
\text { resembled a moist } \\
\text { salt. }\end{array}$ \\
\hline & 5 & 18.0 & 128.5--Drainable & $\begin{array}{l}\text { 115.3--Lower half } \\
\text { 100.0--Upper half }\end{array}$ & $\begin{array}{l}\text { Solids were gray } \\
\text { and resembled a wet } \\
\text { salt. Drainable } \\
\text { liquid was gray and } \\
\text { opaque with no } \\
\text { organic layer. }\end{array}$ \\
\hline & 6 & 18.0 & 0.0 & $\begin{array}{l}\text { 143.3--Lower half } \\
\text { 240.5--Upper half }\end{array}$ & $\begin{array}{l}\text { Lower half solids } \\
\text { were gray and } \\
\text { resembled a wet } \\
\text { sludge. } \\
\text { Upper half solids } \\
\text { were gray and } \\
\text { resembled a salt } \\
\text { slurry. }\end{array}$ \\
\hline
\end{tabular}

Note:

${ }^{1}$ Approximate inches extruded 
Table B2-3. Sample Receipt and Extrusion Information for Tank 241-BY-112, Core 177.

\begin{tabular}{|c|c|c|c|c|c|}
\hline$\sqrt{11}$ & 80.9110 .11 & 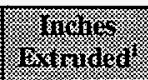 & 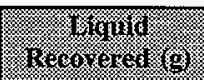 & 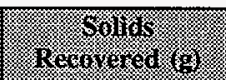 & Decerilitina: \\
\hline \multirow[t]{7}{*}{21} & Field blank & 0.0 & 267.0--Drainable & 0.0 & $\begin{array}{l}\text { Drainable liquid } \\
\text { was clear and } \\
\text { colorless. }\end{array}$ \\
\hline & 1 & 4.0 & 0.0 & 33.1--Lower half & $\begin{array}{l}\text { Solids were } \\
\text { white and black } \\
\text { and resembled a } \\
\text { dry salt. }\end{array}$ \\
\hline & 2 & 4.0 & 0.0 & 65.4--Lower half & $\begin{array}{l}\text { Solids were } \\
\text { yellow to brown } \\
\text { and resembled a } \\
\text { dry salt. }\end{array}$ \\
\hline & 3 & 6.0 & 0.0 & 76.6--Lower half & $\begin{array}{l}\text { Solids were } \\
\text { brown and } \\
\text { resembled a dry } \\
\text { salt. }\end{array}$ \\
\hline & 4 & 10.0 & 0.0 & $\begin{array}{l}\text { 166.2--Lower half } \\
\text { 43.0--Upper half }\end{array}$ & $\begin{array}{l}\text { Solids were dark } \\
\text { gray and } \\
\text { resembled a } \\
\text { moist salt. }\end{array}$ \\
\hline & 5 & 14.0 & 40.0--Drainable & $\begin{array}{l}\text { 157.6--Lower half } \\
\text { 155.6--Upper half }\end{array}$ & $\begin{array}{l}\text { Solids were dark } \\
\text { gray and } \\
\text { resembled a salt } \\
\text { slurry. } \\
\text { Drainable liquid } \\
\text { was gray and } \\
\text { opaque with no } \\
\text { organic layer. }\end{array}$ \\
\hline & 6 & 6.0 & 0.0 & 122.1--Lower half & $\begin{array}{l}\text { Solids were dark } \\
\text { gray and } \\
\text { resembled a } \\
\text { moist salt. }\end{array}$ \\
\hline
\end{tabular}

Note:

${ }^{1}$ Approximate inches extruded 


\section{B2.1.2 Sample Analysis}

The analyses performed on the push mode samples were limited to those required by the safety screening DQO. The analyses required by the safety screening DQO included analyses for thermal properties by DSC, moisture content by TGA, and content of fissile material by total alpha activity analysis.

Differential scanning calorimetry and TGA were performed on all samples. Quality control (QC) tests included performing the analyses in duplicate and the use of standards.

Total alpha activity measurements were performed on samples that had been fused in a solution of potassium, then dissolved in acid. The resulting solution was dried on a counting planchet and counted in an alpha proportional counter. Quality control tests included standards, spikes, blanks, and duplicate analyses.

Ion chromatography (IC) was performed on samples that had been prepared by water digestion. Quality control tests included standards, spikes, blanks, and duplicate analyses. Baldwin (1997) required measuring the full suite of IC analytes.

Inductively coupled plasma (ICP) spectrometry was performed on all samples and was prepared by a fusion procedure followed by dissolution in acid. Quality control tests included standards, blanks, spikes, and duplicate analyses. Baldwin (1997) required analyzing the full suite of ICP elements.

All reported analyses were performed in accordance with approved laboratory procedures. Table N2-4 lists the sample numbers and applicable analyses.

Table B2-4. Tank 241-BY-112 Sample Analysis Summary. ${ }^{1}$ (3 sheets)

\begin{tabular}{|c|c|c|c|c|}
\hline ) & segnient & 1076100 & Ooninglo & 4hative \\
\hline \multirow[t]{8}{*}{174} & \multirow[t]{4}{*}{1} & \multirow[t]{4}{*}{ Lower half } & S96T005865 & Bulk density \\
\hline & & & S96T005873 & DSC, TGA, TIC, TOC \\
\hline & & & S96T005897 & IC \\
\hline & & & S96T005889 & ICP, Alpha \\
\hline & \multirow[t]{4}{*}{2} & \multirow[t]{4}{*}{ Lower half } & S96T005866 & Bulk density \\
\hline & & & S96T005874 & DSC, TGA, TIC, TOC \\
\hline & & & S96T005898 & IC \\
\hline & & & S96T005890 & ICP, Alpha \\
\hline
\end{tabular}


HNF-SD-WM-ER-701 Rev. 0

Table B2-4. Tank 241-BY-112 Sample Analysis Summary. ${ }^{1}$ (3 sheets)

\begin{tabular}{|c|c|c|c|c|}
\hline 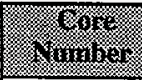 & 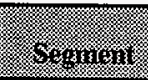 & I. I0, & Saingl f & 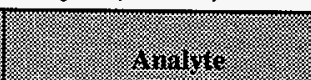 \\
\hline \multirow{23}{*}{$\begin{array}{l}174 \\
\text { (Cont'd) }\end{array}$} & \multirow[t]{4}{*}{3} & \multirow[t]{4}{*}{ Lower half } & S96T005867 & Bulk density \\
\hline & & & S96T005875 & DSC, TGA, TIC, TOC \\
\hline & & & S96T005899 & IC \\
\hline & & & S96T005891 & ICP, Alpha \\
\hline & \multirow[t]{4}{*}{4} & \multirow[t]{4}{*}{ Lower half } & S96T005868 & Bulk density \\
\hline & & & S96T005876 & DSC, TGA, TIC, TOC \\
\hline & & & S96T005900 & IC \\
\hline & & & S96T005892 & ICP, Alpha \\
\hline & \multirow[t]{8}{*}{5} & Drainable liquid & S96T005907 & $\begin{array}{l}\text { DSC, TGA, TIC, TOC, } \\
\text { specific gravity, IC, ICP, } \\
\text { Alpha }\end{array}$ \\
\hline & & \multirow[t]{4}{*}{ Lower half } & S96T005869 & Bulk density \\
\hline & & & S96T005877 & DSC, TGA, TIC, TOC \\
\hline & & & S96T005901 & IC \\
\hline & & & S96T005893 & ICP, Alpha \\
\hline & & \multirow[t]{3}{*}{ Upper half } & S96T005878 & DSC, TGA, TIC, TOC \\
\hline & & & S96T005902 & IC \\
\hline & & & S96T005894 & ICP \\
\hline & \multirow[t]{7}{*}{6} & \multirow[t]{4}{*}{ Lower half } & S96T005871 & Bulk density \\
\hline & & & S96T005879 & DSC, TGA, TIC, TOC \\
\hline & & & S96T005903 & IC \\
\hline & & & S96T005895 & ICP, Alpha \\
\hline & & \multirow[t]{3}{*}{ Upper half } & S96T005880 & DSC, TGA, TIC, TOC \\
\hline & & & S96T005904 & IC \\
\hline & & & S96T005896 & $\overline{I C P}$ \\
\hline \multirow[t]{4}{*}{177} & \multirow[t]{4}{*}{1} & \multirow[t]{4}{*}{ Lower half } & S96T005911 & Bulk density \\
\hline & & & S96T005917 & DSC, TGA, TIC, TOC \\
\hline & & & S96T005935 & IC \\
\hline & & & S96T005929 & ICP, Alpha \\
\hline
\end{tabular}


Table B2-4. Tank 241-BY-112 Sample Analysis Summary.' (3 sheets)

\begin{tabular}{|c|c|c|c|c|}
\hline Vintiber & $8 \%$. & 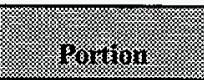 & Somplo & Analyes \\
\hline \multirow{27}{*}{$\begin{array}{l}177 \\
\text { (Cont'd) }\end{array}$} & \multirow[t]{4}{*}{2} & \multirow[t]{4}{*}{ Lower half } & S96T005912 & Bulk density \\
\hline & & & S96T005918 & DSC, TGA, TIC, TOC \\
\hline & & & S96T005936 & IC \\
\hline & & & S96T005930 & ICP, Alpha \\
\hline & \multirow[t]{4}{*}{3} & \multirow[t]{4}{*}{ Lower half } & S96T005913 & Bulk density \\
\hline & & & S96T005919 & DSC, TGA, TIC, TOC \\
\hline & & & S96T005937 & IC \\
\hline & & & S96T005931 & ICP, Alpha \\
\hline & \multirow[t]{7}{*}{4} & \multirow[t]{4}{*}{ Lower half } & S96T005915 & Bulk density \\
\hline & & & S96T005921 & DSC, TGA, TIC, TOC \\
\hline & & & S96T005939 & IC \\
\hline & & & S96T005933 & ICP, Alpha \\
\hline & & \multirow[t]{3}{*}{ Upper half } & S96T005920 & DSC, TGA, TIC, TOC \\
\hline & & & S96T005938 & IC \\
\hline & & & S96T005932 & ICP \\
\hline & \multirow[t]{8}{*}{5} & Drainable liquid & S96T005960 & $\begin{array}{l}\text { DSC, TGA, TIC, TOC, } \\
\text { specific gravity, IC, ICP, } \\
\text { Alpha }\end{array}$ \\
\hline & & \multirow[t]{4}{*}{ Lower half } & S96T005942. & Bulk density \\
\hline & & & S96T005951 & DSC, TGA, TIC, TOC \\
\hline & & & S96T005959 & IC \\
\hline & & & S96T005957 & ICP, Alpha \\
\hline & & \multirow[t]{3}{*}{ Upper half } & S96T005950 & DSC, TGA, TIC, TOC \\
\hline & & & S96T005958 & IC \\
\hline & & & S96T005956 & ICP \\
\hline & \multirow[t]{4}{*}{6} & \multirow[t]{4}{*}{ Lower half } & S96T005916 & Bulk density \\
\hline & & & S96T005922 & DSC, TGA, TIC, TOC \\
\hline & & & S96T005940 & $\mathrm{IC}$ \\
\hline & & & S96T005934 & ICP, Alpha \\
\hline
\end{tabular}

Note: 


\section{B2.1.3 Analytical Results}

This section summarizes the sampling and analytical results associated with the October 1996 push mode sampling and analysis of tank 241-BY-112. Table B2-5 shows the location of total alpha activity, percent water, energetics, IC, bulk density, specific gravity TIC, TOC, and ICP analytical results associated with this tank. These results are documented in Nuzum (1997).

Table B2-5. Analytical Tables.

\begin{tabular}{|c|c|}
\hline U: & Woble Tinuber \\
\hline Summary data for metals by ICP & B2-6 through B2-42 \\
\hline Anions by IC & B2-43 through B2-50 \\
\hline Bulk density & B2-51 \\
\hline Differential scanning calorimetry & B2-52 \\
\hline Percent water & B2-53 \\
\hline Specific gravity & B2-54 \\
\hline Total alpha activity & B2-55 \\
\hline Total inorganic carbon & B2-56 \\
\hline Total organic carbon & B2-57 \\
\hline
\end{tabular}

The four QC parameters assessed in conjunction with the tank 241-BY-112 samples were standard recoveries, spike recoveries, duplicate analyses (relative percent differences [RPDs]), and blanks. The QC criteria are specified in the Baldwin (1997). Sample and duplicate pairs, in which any QC parameter was outside these limits, are footnoted in the sample mean column of the following data summary tables with an $a, b, c, d, e$, or $f$ as follows:

- $\quad \mathrm{a}$ " indicates the standard recovery was below the QC limit

- $\quad$ "b" indicates the standard recovery was above the QC limit

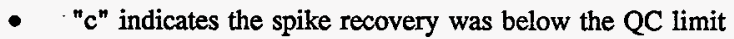

- $\quad \mathrm{d} "$ indicates the spike recovery was above the QC limit

- $\quad \mathrm{e}$ " indicates the RPD was above the QC limit

- $\quad \mathrm{f}^{\mathrm{n}}$ indicates blank contamination. 
B2.1.3.1 Total Alpha Activity. Analyses for total alpha activity were performed on the samples recovered from tank 241-BY-112. Alpha total (AT) analyses were requested for lower half segments only in accordance with Baldwin (1997). The samples were prepared by fusion digestion. Two fusions were prepared per sample (for duplicate results). Liquid AT results were below the total alpha activity notification limit of $61.5 \mu \mathrm{Ci} / \mathrm{mL}$. All solid AT results were below the total alpha activity notification limit of $33.1 \mu \mathrm{Ci} / \mathrm{g}$ (based on a bulk density of $1.86 \mathrm{~g} / \mathrm{mL}$ ).

B2.1.3.2 Thermogravimetric Analysis. Thermogravimetric analysis measures the mass of a sample as its temperature is increased at a constant rate. Nitrogen is passed over the sample during heating to remove any released gases. A decrease in the weight of a sample during TGA represents a loss of gaseous matter from the sample, through evaporation or through a reaction that forms gas phase products. The moisture content is estimated by assuming that all TGA sample weight loss up to a certain temperature (typically 150 to $200^{\circ} \mathrm{C}$ [ 300 to $\left.390^{\circ} \mathrm{F}\right]$ ) is caused by water evaporation. The temperature limit for moisture loss is chosen by the operator at an inflection point on the TGA plot. Other volatile matter fractions can often be differentiated by inflection points as well.

A second analysis of the lower half of segment 1 of core 177 (S96T005917) was performed because of the differences in appearance of the thermograms between the sample and duplicate. These differences were not seen in the replicate analysis. Table B2-53 shows the results for both analyses.

B2.1.3.3 Differential Scanning Calorimetry. In a DSC analysis, heat absorbed or emitted by a substance is measured while the sample is heated at a constant rate. Nitrogen is passed over the sample material to remove any gases being released. The onset temperature for an endothermic or exothermic event is determined graphically.

The exothermic energy, based on dry weight of subsample, was calculated for all subsamples. The average of the TGA results for each subsample was used in the dry weight correction for that subsample.

No exotherms above the threshold were observed. However, because of sample heterogeneity, three samples exceeded the limit of $480 \mathrm{~J} / \mathrm{g}$ at the upper 95 percent confidence interval of the mean on a dry basis. The percent water for the same samples exceeded 25 percent, and the TOC for the samples was less than the limit of $30,000 \mu \mathrm{g} / \mathrm{g}$, There is no DSC safety concern for tank 241-BY-112.

B2.1.3.4 Inductively Coupled Plasma. Samples were prepared by fusion or acid digests. Although a full suite of analytes were reported, only lithium was specifically requested. The potassium and nickel results for the ICP fusion analyses were ignored because of bias. The samples were prepared in a nickel crucible by fusion using potassium hydroxide. 
B2.1.3.5 Total Organic Carbon. Table B2-57 shows the results of the TOC analyses. The lower half of segment 4 of core 174 (S96T005876) and the lower half of segment 4 of core 177 (\$96T005921) results exceeded the notification limits set forth in Baldwin (1997). Notifications were made in accordance with Baldwin (1997).

The dry weight notification limit for TOC is $30,000 \mu \mathrm{g} / \mathrm{g}$. Table C1-4 shows the mean dry weight sample results including the upper 95 percent confidence level of the mean. The percent water measured for these samples exceed 23 percent. The DSC measured for these samples is less than the limit of $480 \mathrm{~J} / \mathrm{g}$. The low DSC results associated with the relatively high TOC values indicates a majority of the measured carbon is no longer associated with hydrogen containing compounds and not reactive. There is no TOC safety concern for tank 241-BY-112.

B.2.1.3.6 Total Inorganic Carbon. Table B2-56 shows the TIC results as "opportunistic." The analytical results are not discussed in the laboratory report (Nuzum, 1997). The elevated TIC results are not unexpected. Because of the ITS2 unit and boiling that occurred, conditions were favorable to carbonate formation.

B2.1.3.7 Specific Gravity. There were no exceptions to the QC parameters stated in Baldwin (1977) for these subsamples.

B2.1.3.8 Ion Chromatography. Tables $\mathrm{B} 2-43$ through $\mathrm{B} 2-50$ show the $\mathrm{IC}$ results as opportunistic analyses. These analytes are not discussed in the laboratory report (Nuzum 1997).

B2.1.3.9 Density. Bulk density was requested only on lower half segments in accordance with Baldwin (1997). Bulk density could not be determined for segment 1 of core 177 (S96T005911) because of subsample dryness. Results from bulk density tests ranged from $1.03 \mathrm{~g} / \mathrm{mL}$ to $1.86 \mathrm{~g} / \mathrm{mL}$. The main density was $1.46 \mathrm{~g} / \mathrm{mL}$.

\section{B2.2 ANALYTICAL DATA TABLES}

The following tables are the analytical results associated with the October 1996 push mode sampling and analysis of tank 241-BY-112. 


\begin{tabular}{|c|c|c|c|c|c|}
\hline $0 S S^{6} 6 \mathrm{I}$ & $00 t^{6} 8 \mathrm{I}$ & $00 L^{\circ} 0 z$ & IाЕY ІәмOT & $9: L L I$ & $\downarrow \varepsilon 6 S 00 \mathrm{~L} 96 \mathrm{~S}$ \\
\hline $00 z^{\prime} \varepsilon z$ & $008^{\circ} \mathrm{IZ}$ & $009^{6}+z$ & ҒГеч дәмOТ & \multirow[b]{2}{*}{$s: L L \mathrm{I}$} & $\angle S 6 S 00 . \mathrm{L} 96 \mathrm{~S}$ \\
\hline OSL'IZ & $00 I^{\prime} z z$ & $00 t^{\prime} \mathrm{IZ}$ & freप Jədd & & $9 \$ 6 \$ 00 \mathrm{I} 96 \mathrm{~S}$ \\
\hline $0 S 6^{\circ} \mathrm{SI}$ & $00 S^{\prime} \mathrm{SI}$ & $00 t^{6} 9 \mathrm{I}$ & Ғ[Еप دәмOT & \multirow[b]{2}{*}{$t: L L I$} & $\varepsilon \varepsilon 6 \$ 00.296 \mathrm{~S}$ \\
\hline$: 000 \varepsilon^{\prime} \varepsilon I$ & $008^{6} \triangleright I$ & $008^{6} \mathrm{II}$ & Jाеप & & $z \varepsilon 6 \mathrm{~S} 00 \mathrm{~L} 96 \mathrm{~S}$ \\
\hline $059^{\circ} \mathrm{I}$ & $0 z S^{6} \mathrm{I}$ & $08 L^{6} \mathrm{I}$ & IIЕप ІәмоТ & $\varepsilon: L L \mathrm{I}$ & IE6S00.L96S \\
\hline SLI'I & $00 I^{6} \mathrm{I}$ & $0 S Z^{6} \mathrm{I}$ & Iтеप دәмОТ & $\tau: L L I$ & $0 \varepsilon 6 S 00 \mathrm{~L} 96 \mathrm{~S}$ \\
\hline $0 S Z^{\prime} Z I$ & $00 t^{\prime} \varepsilon I$ & $00 I^{\prime} \mathrm{II}$ & Ғૃष् ІәмоТ & $I: L L I$ & $626 \mathrm{~S} 00 \mathrm{I} 96 \mathrm{~S}$ \\
\hline $0 S Z^{\prime} Z \varepsilon$ & $00 L^{\prime} z \varepsilon$ & $008^{6} I E$ & झाषप دәMOT & \multirow[b]{2}{*}{$9:+<L$} & S68S00L96S \\
\hline os\&'9z & $000^{\circ} 92$ & $00 L^{5} 9 z$ & Jreप rəddn & & 968S00L96S \\
\hline $00 \varepsilon^{\prime} z \varepsilon$ & $00 \varepsilon^{\prime} \varepsilon \varepsilon$ & $00 \varepsilon^{6} I \varepsilon$ & ЭГеч дәмоТ & \multirow[b]{2}{*}{$s: t<I$} & E68S00L96S \\
\hline $000^{\circ}+\varepsilon$ & $000^{\circ} 9 \varepsilon$ & $000^{6} \tau \varepsilon$ & mey soddn & & t68S00.I96S \\
\hline $0 S t^{6} L I$ & $00 I^{\prime} \angle I$ & $008^{6} \mathrm{LI}$ & ҒГеप ІОМОТ & $t: t L I$ & $268500 \mathrm{~L} 96 \mathrm{~S}$ \\
\hline$S S 8^{6} I$ & $0 \neq 8^{6} \mathrm{I}$ & $0 \angle 8^{6} \mathrm{I}$ & Ғाеप ІәмОТ & $\varepsilon: \nabla L I$ & I68S00.L96S \\
\hline $00 L^{6} \mathrm{I}$ & $08 S^{6} I$ & $0 z 8^{4} \mathrm{I}$ & ІाЕप ІәмОТ & $z: t L I$ & $068 S 00 \mathrm{~L} 96 \mathrm{~S}$ \\
\hline $00 z^{\prime} \varepsilon 9$ & $00 t^{\prime} \angle 9$ & $000^{\prime} 65$ & J[Еप دәмOT & $I: t L I$ & $688 S 00 \mathrm{~L} 96 \mathrm{~S}$ \\
\hline $8 \%$ & 7. & 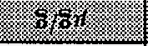 & : & \multicolumn{2}{|c|}{. } \\
\hline$: \infty 000 \varepsilon^{6}+S$ & $009^{6}+s$ & $000^{\circ} \nabla s$ & 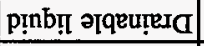 & $s: L L I$ & 096S00L96S \\
\hline :000999 & $00 S^{\prime} 95$ & $00 L^{\circ} 9 S$ & 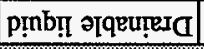 & $s: t<\mathrm{I}$ & LO6S00L96S \\
\hline 1uror & mugr: & In & & & spming \\
\hline "พอบที & arograme & 111596 & 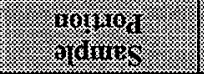 & momings: & 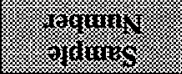 \\
\hline
\end{tabular}

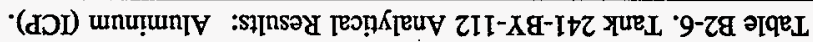


Table B2-7. Tank 241-BY-112 Analytical Results: Antimony (ICP).

\begin{tabular}{|c|c|c|c|c|c|}
\hline ovingle & S.9.7. & Symple: & resint & Yrishicate & litran \\
\hline Marius & & & $194 \mathrm{~min}$ & $4 y$ rat & (1) \\
\hline S96T005907 & $174: 5$ & Drainable liquid & $<36.1$ & $<36.1$ & $<36.1$ \\
\hline S96T005960 & $177: 5$ & Drainable liquid & $<36.1$ & $<36.1$ & $<36.1^{\text {QC:d }}$ \\
\hline 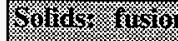 & (1) & (3) & 109 & 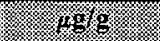 & $2=1.96$ \\
\hline S96T005889 & 174: 1 & Lower half & $<1,260$ & $<1,180$ & $<1,220$ \\
\hline S96T005890 & 174: 2 & Lower half & $<1,180$ & $<1,150$ & $<1,165$ \\
\hline S96T005891 & 174: 3 & Lower half & $<1,170$ & $<1,310$ & $<1,240$ \\
\hline S96T005892 & $174: 4$ & Lower half & $<1,180$ & $<1,110$ & $<1,145$ \\
\hline S96T005894 & \multirow[t]{2}{*}{$174: 5$} & Upper half & $<1,270$ & $<1,180$ & $<1,225$ \\
\hline S96T005893 & & Lower half & $<1,200$ & $<1,200$ & $<1,200$ \\
\hline S96T005896 & \multirow[t]{2}{*}{$174: 6$} & Upper half & $<1,220$ & $<1,210$ & $<1,215$ \\
\hline S96T005895 & & Lower half & $<1,230$ & $<1,340$ & $<1,285$ \\
\hline S96T005929 & $177: 1$ & Lower half & $<1,190$ & $<1,110$ & $<1,150$ \\
\hline S96T005930 & $177: 2$ & Lower half & $<1,140$ & $<1,120$ & $<1,130$ \\
\hline S96T005931 & $177: 3$ & Lower half & $<1,110$ & $<1,260$ & $<1,185$ \\
\hline S96T005932 & \multirow[t]{2}{*}{ 177: 4} & Upper half & $<1,230$ & $<1,190$ & $<1,210$ \\
\hline S96T005933 & & Lower half & $<1,280$ & $<1,250$ & $<1,265$ \\
\hline S96T005956 & \multirow[t]{2}{*}{$177: 5$} & Upper half & $<1,310$ & $<1,290$ & $<1,300$ \\
\hline S96T005957 & & Lower half & $<1,350$ & $<1,260$ & $<1,305$ \\
\hline S96T005934 & $177: 6$ & Lower half & $<1,290$ & $<1,320$ & $<1,305$ \\
\hline
\end{tabular}


Table B2-8. Tank 241-BY-112 Analytical Results: Arsenic (ICP).

\begin{tabular}{|c|c|c|c|c|c|}
\hline $\begin{array}{l}\text { Sonnuls } \\
\text { iriminor }\end{array}$ & oldinglis & Shorrole & itcsint & 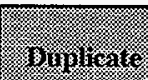 & riegn \\
\hline \multicolumn{3}{|l|}{ Emanis: } & .69619 & 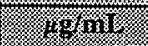 & 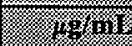 \\
\hline S96T005907 & 174: 5 & Drainable liquid & $<60.1$ & $<60.1$ & $<60.1$ \\
\hline S96T005960 & $177: 5$ & Drainable liquid & $<60.1$ & $<60.1$ & $<60.1$ \\
\hline \multicolumn{2}{|c|}{ Solido Ration } & $x_{1}$ & (1) & 1.96. & $14 \mathrm{~g}, \mathrm{~g}$ \\
\hline S96T005889 & $174: 1$ & Lower half & $<2,110$ & $<1,970$ & $<2,040$ \\
\hline S96T005890 & 174: 2 & Lower half & $<1,960$ & $<1,920$ & $<1,940$ \\
\hline S96T005891 & $174: 3$ & Lower half & $<1,960$ & $<2,180$ & $<2,070$ \\
\hline S96T005892 & 174: 4 & Lower half & $<1,960$ & $<1,840$ & $<1,900$ \\
\hline S96T005894 & \multirow[t]{2}{*}{$174: 5$} & Upper half & $<2,120$ & $<1,970$ & $<2,045$ \\
\hline S96T005893 & & Lower half & $<2,000$ & $<2,010$ & $<2,005$ \\
\hline S96T005896 & \multirow[t]{2}{*}{$174: 6$} & Upper half & $<2,030$ & $<2,010$ & $<2,020$ \\
\hline S96T005895 & & Lower half & $<2,050$ & $<2,240$ & $<2,145$ \\
\hline S96T005929 & $177: 1$ & Lower half & $<1,990$ & $<1,860$ & $<1,925$ \\
\hline S96T005930 & 177: 2 & Lower half & $<1,910$ & $<1,860$ & $<1,885$ \\
\hline S96T005931 & $177: 3$ & Lower half & $<1,850$ & $<2,090$ & $<1,970$ \\
\hline S96T005932 & \multirow[t]{2}{*}{ 177: 4} & Upper half & $<2,050$ & $<1,980$ & $<2,015$ \\
\hline S96T005933 & & Lower half & $<2,130$ & $<2,080$ & $<2,105$ \\
\hline S96T005956 & \multirow[t]{2}{*}{$177: 5$} & Upper half & $<2,190$ & $<2,140$ & $<2,165$ \\
\hline S96T005957 & & Lower half & $<2,250$ & $<2,110$ & $<2,180$ \\
\hline S96T005934 & $177: 6$ & Lower half & $<2,160$ & $<2,200$ & $<2,180$ \\
\hline
\end{tabular}




\begin{tabular}{|c|c|c|c|c|c|}
\hline $060^{4}\lfloor>$ & $00 I^{\prime} \mathrm{I}>$ & $080^{6}\lceil>$ & JाЕप دәмOT & $9: \angle L I$ & $\downarrow \mathcal{E} 6 \mathrm{~S} 00 \mathrm{~L} 96 \mathrm{~S}$ \\
\hline $060^{\circ} \mathrm{I}>$ & OSO $\mathrm{I}>$ & OEI'I> & І[Еप ІәМОТ & \multirow[b]{2}{*}{$s: L L I$} & $\angle S 6 S 00 L 96 \mathrm{~S}$ \\
\hline $080^{\circ} \mathrm{I}>$ & $0 L 0^{6} \mathrm{I}>$ & $060^{\circ}[>$ & fleq rədd $\Omega$ & & 9S6S00L96S \\
\hline $\mathrm{OSO}^{\circ} \mathrm{IT}$ & $0+0^{6} 1>$ & $090^{\circ} \mathrm{L}>$ & fाEप ІәмOT & \multirow[b]{2}{*}{$\nabla: L L I$} & $\varepsilon \varepsilon 6 \mathrm{~S} 00 \mathrm{~L} 96 \mathrm{~S}$ \\
\hline $500^{\circ} i>$ & $886>$ & $020^{\circ} \mathrm{I}>$ & freप Jədd $\Omega$ & & $z \varepsilon 6 \mathrm{~S} 00 \mathrm{~L} 96 \mathrm{~S}$ \\
\hline $886>$ & $0 S 0^{6} I>$ & $926>$ & Ғाеप дәмоТ & $\varepsilon: L L I$ & IE6S00L96S \\
\hline$z+6>$ & IE6> & ES6> & J[ЕЧ ІәмоТ & $\tau: L L I$ & $0 \varepsilon 6 \mathrm{~S} 00 \mathrm{~L} 96 \mathrm{~S}$ \\
\hline s.196> & $826>$ & $\$ 66>$ & IाЕч دәмоТ & $I: L L I$ & $626 \mathrm{~S} 00 \mathrm{~L} 96 \mathrm{~S}$ \\
\hline$S \angle 0^{\prime} I>$ & $O Z I^{\prime} I>$ & $0 E 0^{\prime} I>$ & भाЕप IOMOT & \multirow[b]{2}{*}{$9: \forall \angle I$} & S68S00L96S \\
\hline $\mathcal{S I O}^{c} I>$ & OLO'I $>$ & $0 Z 0^{6} I>$ & I[RY Iədd & & 968S00L96S \\
\hline $666>$ & $000^{6} \mathrm{I}>$ & $866>$ & JॉЕ IәMOT & \multirow[b]{2}{*}{$s: t L I$} & E68S00L96S \\
\hline$S^{\circ} \varepsilon Z O^{\prime} I>$ & $L 86>$ & $090^{6} I>$ & JाEप Jodd $\Omega$ & & $768500 \mathrm{~L} 96 \mathrm{~S}$ \\
\hline$S: I S 6>$ & $226>$ & $186>$ & Ғ[Еप ІәмОТ & $t: t L I$ & Z68S00II96S \\
\hline$S^{\circ}+\varepsilon 0^{\circ} I>$ & $060^{6} I>$ & $6 \angle 6>$ & J[Еप IәMOT & $\varepsilon: t L I$ & I68S00L96S \\
\hline$z L 6>$ & $296>$ & $286>$ & J[Еप دәмOัT & $\tau: t L I$ & $068 \mathrm{~S} 00 \mathrm{~L} 96 \mathrm{~S}$ \\
\hline$S 810^{6} I>$ & $L 86\rangle$ & $0 S 0^{c} I>$ & IाЕप IәMOT & $I: \nabla L I$ & $688 \mathrm{~S} 00 \mathrm{~L} 96 \mathrm{~S}$ \\
\hline \%का & 7. & 8,211 & 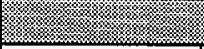 & \multicolumn{2}{|c|}{ 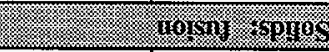 } \\
\hline$[0 \varepsilon>$ & $I^{\circ} 0 \varepsilon>$ & I.0 $0 \varepsilon>$ & 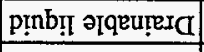 & $s: \angle L I$ & 096S00L96S \\
\hline$I^{\circ} 0 \varepsilon>$ & {$[0 \varepsilon>$} & $I^{\circ} 0 \varepsilon>$ & pịnb!̣I әqеuṭes & $s: \nabla L I$ & L06S00L96S \\
\hline $9 \pi+3 \%$ & 87 grif & 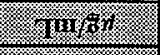 & & & (1) 810 \\
\hline 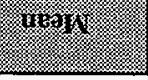 & oneorging & 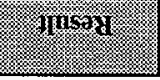 & 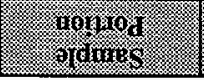 & 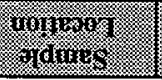 & rogromis: \\
\hline
\end{tabular}

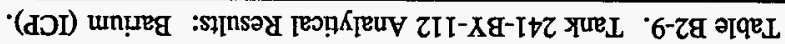


Table B2-10. Tank 241-BY-112 Analytical Results: Beryllium (ICP).

\begin{tabular}{|c|c|c|c|c|c|}
\hline siminiser & sominis & 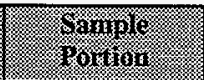 & IIItis: & 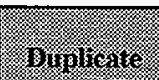 & $196 a n$ \\
\hline 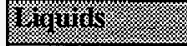 & 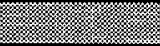 & s: & 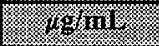 & 1.96101 & 14961 \\
\hline S96T005907 & $174: 5$ & Drainable liquid & $<3$ & $<3$ & $<3$ \\
\hline S96T005960 & 177: 5 & Drainable liquid & $<3$ & $<3$ & $<3$ \\
\hline Woras Busion & & & (x) & 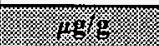 & 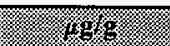 \\
\hline S96T005889 & 174: 1 & Lower half & $<105$ & $<98.7$ & $<101.85$ \\
\hline S96T005890 & 174: 2 & Lower half & $<98.2$ & $<96.2$ & $<97.2$ \\
\hline S96T005891 & 174: 3 & Lower half & $<97.9$ & $<109$ & $<103.45$ \\
\hline S96T005892 & $174: 4$ & Lower half & $<98.1$ & $<92.2$ & $<95.15$ \\
\hline S96T005894 & \multirow[t]{2}{*}{$174: 5$} & Upper half & $<106$ & $<98.7$ & $<102.35$ \\
\hline S96T005893 & & Lower half & $<99.8$ & $<100$ & $<99.9$ \\
\hline S96T005896 & \multirow[t]{2}{*}{$174: 6$} & Upper half & $<102$ & $<101$ & $<101.5$ \\
\hline S96T005895 & & Lower half & $<103$ & $<112$ & $<107.5$ \\
\hline S96T005929 & 177: 1 & Lower half & $<99.5$ & $<92.8$ & $<96.15$ \\
\hline S96T005930 & 177: 2 & Lower half & $<95.3$ & $<93.1$ & $<94.2$ \\
\hline S96T005931 & $177: 3$ & Lower half & $<92.6$ & $<105$ & $<98.8$ \\
\hline S96T005932 & \multirow[t]{2}{*}{$177: 4$} & Upper half & $<102$ & $<98.8$ & $<100.4$ \\
\hline S96T005933 & & Lower half & $<106$ & $<104$ & $<105$ \\
\hline S96T005956 & \multirow[t]{2}{*}{$177: 5$} & Upper half & $<109$ & $<107$ & $<108$ \\
\hline S96T005957 & & Lower half & $<113$ & $<105$ & $<109$ \\
\hline S96T005934 & $177: 6$ & Lower half & $<108$ & $<110$ & $<109$ \\
\hline
\end{tabular}


Table B2-11. Tank 241-BY-112 Analytical Results: Bismuth (ICP).

\begin{tabular}{|c|c|c|c|c|c|}
\hline - & 8901918 & gormol & Resint & Dingleate & 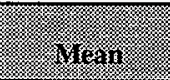 \\
\hline Uigunis: & 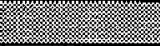 & & 15 & 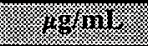 & $139 \% 1 \mathrm{in}$ \\
\hline S96T005907 & $174: 5$ & Drainable liquid & $<60.1$ & $<60.1$ & $<60.1$ \\
\hline S96T005960 & $177: 5$ & Drainable liquid & $<60.1$ & $<60.1$ & $<60.1$ \\
\hline \multicolumn{3}{|l|}{ 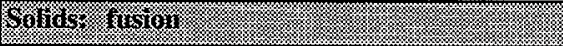 } & 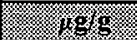 & . & 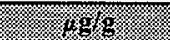 \\
\hline S96T005889 & 174: 1 & Lower half & $<2,110$ & $<1,970$ & $<2,040$ \\
\hline S96T005890 & $174: 2$ & Lower half & $<1,960$ & $<1,920$ & $<1,940$ \\
\hline S96T005891 & 174: 3 & Lower half & $<1,960$ & $<2,180$ & $<2,070$ \\
\hline S96T005892 & $174: 4$ & Lower half & $<1,960$ & $<1,840$ & $<1,900$ \\
\hline S96T005894 & \multirow[t]{2}{*}{$174: 5$} & Upper half & $<2,120$ & $<1,970$ & $<2,045$ \\
\hline S96T005893 & & Lower half & $<2,000$ & $<2,010$ & $<2,005$ \\
\hline S96T005896 & \multirow[t]{2}{*}{$174: 6$} & Upper half & $<2,030$ & $<2,010$ & $<2,020$ \\
\hline S96T005895 & & Lower half & $<2,050$ & $<2,240$ & $<2,145$ \\
\hline S96T005929 & 177: 1 & Lower half & $<1,990$ & $<1,860$ & $<1,925$ \\
\hline S96T005930 & 177: 2 & Lower half & $<1,910$ & $<1,860$ & $<1,885$ \\
\hline S96T005931 & $177: 3$ & Lower half & $<1,850$ & $<2,090$ & $<1,970$ \\
\hline S96T005932 & \multirow[t]{2}{*}{ 177: 4} & Upper half & $<2,050$ & $<1,980$ & $<2,015$ \\
\hline S96T005933 & & Lower half & $<2,130$ & $<2,080$ & $<2,105$ \\
\hline S96T005956 & \multirow[t]{2}{*}{$177: 5$} & Upper half & $<2,190$ & $<2,140$ & $<2,165$ \\
\hline S96T005957 & & Lower half & $<2,250$ & $<2,110$ & $<2,180$ \\
\hline S96T005934 & $177: 6$ & Lower half & $<2,160$ & $<2,200$ & $<2,180$ \\
\hline
\end{tabular}




\begin{tabular}{|c|c|c|c|c|c|}
\hline $060^{\circ} I>$ & $00 I^{6} \mathrm{I}>$ & $080^{6}\lceil>$ & I[еप JәMOT] & $9: L L I$ & $t \varepsilon 6 S 00 L 96 S$ \\
\hline $060^{\circ} I>$ & OSO $[>$ & $0 E I^{6} I>$ & ЭГеप ләмоТ] & \multirow[b]{2}{*}{$S: L L I$} & LS6S00L96S \\
\hline $080^{\circ} I>$ & $0 L 0^{\prime} I>$ & $060^{6}[>$ & İey Iәdd $\Omega$ & & 9S6S00L96S \\
\hline $0 S 0^{6} I>$ & $0+0^{6} I>$ & $090^{\circ} \mathrm{T}>$ & JाЕप IOMOT & \multirow[b]{2}{*}{$\nabla: L L I$} & E\&6S00L96S \\
\hline $\pm 00^{\circ} I>$ & $886>$ & $020^{6} \mathrm{I}>$ & Jley Iədd $n$ & & ఒ\&6S00L96S \\
\hline $886>$ & $0 \mathrm{SO}^{\circ} \mathrm{I}>$ & $926>$ & IIEY IOMOT & $\varepsilon: L L I$ & IE6S00L96S \\
\hline $2 \neq 6>$ & IE6> & $\varepsilon S 6>$ & JाЕप دәмOT & $\tau: L L I$ & $0 \varepsilon 6 \mathrm{~S} 00 \mathrm{~L} 96 \mathrm{~S}$ \\
\hline s.196> & $826>$ & $\$ 66>$ & IाЕप Іәмот & $\mathrm{I}: L L \mathrm{I}$ & $626 \mathrm{~S} 00 \mathrm{~L} 96 \mathrm{~S}$ \\
\hline SLO'I $>$ & $0 Z I^{\prime} I>$ & OEO'I $\mathrm{I}$ & ІГеप гәмоТ & \multirow[b]{2}{*}{$9: \bullet L I$} & S68S00L96S \\
\hline SIO'I > & OTO'I> & $0 Z 0^{\circ} \mathrm{I}>$ & JEY Iodd $\Omega$ & & 968S00L96S \\
\hline $666>$ & $000^{\prime} I>$ & $866>$ & IIEY IOMOT & \multirow[b]{2}{*}{$s: t L I$} & E68S00L96S \\
\hline $\mathrm{S}^{\prime} \varepsilon Z 0^{\circ} \mathrm{I}>$ & $\angle 86>$ & $090^{\circ} \mathrm{I}>$ & 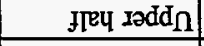 & & $768 S 00 L 96 S$ \\
\hline$S^{*} I S 6>$ & $z 26>$ & I86> & ЈाЕЧ دәмот & $\nabla: \nabla L I$ & Z68S00L96S \\
\hline$S^{*}+\varepsilon 0^{6}[>$ & $060^{\circ}\lceil>$ & $6 L 6>$ & I[еप IәMOT & $\varepsilon: t L \mathrm{I}$ & I68S00L96S \\
\hline$z L 6>$ & $296>$ & $286>$ & नाеप ІәмоТ & $\tau: t L I$ & $068 S 00 L 96 S$ \\
\hline S.8I0'I $>$ & $L 86>$ & $0 S 0^{6} I>$ & Jгеप гәмот & $\mathrm{I}: t L \mathrm{I}$ & $688500 L 96 \mathrm{~S}$ \\
\hline 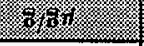 & (7) $1 \%$ & (3) $87 \%$ & & \multicolumn{2}{|c|}{ 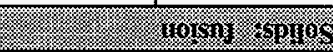 } \\
\hline P:DOS $\$ 9^{\circ} 6 \mathcal{E}$ & $6 \varepsilon$ & $\varepsilon 0 t$ & p!̣nb!̣ әqquा̣ed & $S: L L I$ & 096S00L96S \\
\hline$I^{\prime} \mathfrak{S E}$ & $I^{\prime} \mathcal{S E}$ & 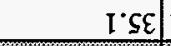 & p!̣nb!̣ əlqeụeda & $s: t L I$ & LO6S00L96S \\
\hline in & $1 \log \%$ \% & mon & & & 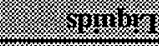 \\
\hline 474 & oustritin: & $\sqrt{11058 \mathrm{~d})}$ & 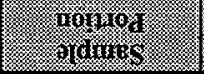 & 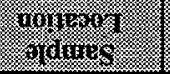 & - \\
\hline
\end{tabular}

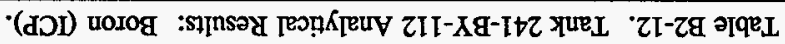


Table B2-13. Tank 241-BY-112 Analytical Results: Cadmium (ICP).

\begin{tabular}{|c|c|c|c|c|c|}
\hline Somples & 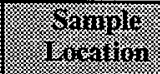 & Sumple & (2) & Diplicarte & inan \\
\hline \multicolumn{3}{|c|}{ Yinum, } & 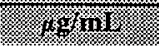 & 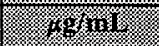 & $3.48 \times 171$ \\
\hline S96T005907 & $174: 5$ & Drainable liquid & $<3$ & $<3$ & $<3$ \\
\hline S96T005960 & $177: 5$ & Drainable liquid & $<3$ & $<3$ & $<3$ \\
\hline \multicolumn{3}{|c|}{ Sollids: fusion : } & $199 / 9$ & 1.928 & 8.1898 \\
\hline S96T005889 & 174: 1 & Lower half & $<105$ & $<98.7$ & $<101.85$ \\
\hline S96T005890 & $174: 2$ & Lower half & $<98.2$ & $<96.2$ & $<97.2$ \\
\hline S96T005891 & $174: 3$ & Lower half & $<97.9$ & $<109$ & $<103.45$ \\
\hline S96T005892 & $174: 4$ & Lower half & 127 & 164 & $145.5^{\mathrm{QC}: 0}$ \\
\hline S96T005894 & \multirow[t]{2}{*}{$174: 5$} & Upper half & 114 & 142 & $128^{Q C: e}$ \\
\hline S96T005893 & & Lower half & $<99.8$ & $<100$ & $<99.9$ \\
\hline S96T005896 & \multirow[t]{2}{*}{ 174: 6} & Upper half & $<102$ & $<101$ & $<101.5$ \\
\hline S96T005895 & & Lower half & $<103$ & $<112$ & $<107.5$ \\
\hline S96T005929 & 177: 1 & Lower half & $<99.5$ & $<92.8$ & $<96.15$ \\
\hline S96T005930 & $177: 2$ & Lower half & $<95.3$ & $<93.1$ & $<94.2$ \\
\hline S96T005931 & 177: 3 & Lower half & $<92.6$ & $<105$ & $<98.8$ \\
\hline S96T005932 & \multirow[t]{2}{*}{$177: 4$} & Upper half & 139 & 136 & 137.5 \\
\hline S96T005933 & & Lower half & 132 & 116 & 124 \\
\hline S96T005956 & \multirow[t]{2}{*}{ 177: 5} & Upper half & 110 & 119 & 114.5 \\
\hline S96T005957 & & Lower half & $<113$ & $<105$ & $<109$ \\
\hline S96T005934 & $177: 6$ & Lower half & $<108$ & $<110$ & $<109$ \\
\hline
\end{tabular}


Table B2-14. Tank 241-BY-112 Analytical Results: Calcium (ICP).

\begin{tabular}{|c|c|c|c|c|c|}
\hline Simnofes: & Singer & S Pringls & Revili: & Buplicat: & $14 \log _{1}$ \\
\hline Zringini & 4 & $8=$ & $189 . \mathrm{nin}$ & ) & 1.99 .101$. \\
\hline S96T005907 & $174: 5$ & Drainable liquid & $<60.1$ & $<60.1$ & $<60.1$ \\
\hline S96T005960 & $177: 5$ & Drainable liquid & $<60.1$ & $<60.1$ & $<60.1$ \\
\hline 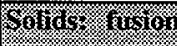 & ) & & $8.6 \%$ & 1196 & 1.98 \\
\hline S96T005889 & 174: 1 & Lower half & $<2,110$ & $<1,970$ & $<2,040$ \\
\hline S96T005890 & $174: 2$ & Lower half & $<1,960$ & $<1,920$ & $<1,940$ \\
\hline S96T005891 & $174: 3$ & Lower half & $<1,960$ & $<2,180$ & $<2,070$ \\
\hline S96T005892 & 174: 4 & Lower half & $<1,960$ & $<1,840$ & $<1,900$ \\
\hline S96T005894 & $174: 5$ & Upper half & $<2,120$ & $<1,970$ & $<2,045$ \\
\hline S96T005893 & & Lower half & $<2,000$ & $<2,010$ & $<2,005$ \\
\hline S96T005896 & $174: 6$ & Upper half & $<2,030$ & $<2,010$ & $<2,020$ \\
\hline S96T005895 & & Lower half & $<2,050$ & $<2,240$ & $<2,145$ \\
\hline S96T005929 & 177: 1 & Lower half & $<1,990$ & $<1,860$ & $<1,925$ \\
\hline S96T005930 & $177: 2$ & Lower half & $<1,910$ & $<1,860$ & $<1,885$ \\
\hline S96T005931 & $177: 3$ & Lower half & $<1,850$ & $<2,090$ & $<1,970$ \\
\hline S96T005932 & $177: 4$ & Upper half & $<2,050$ & $<1,980$ & $<2,015$ \\
\hline S96T005933 & & Lower half & $<2,130$ & $<2,080$ & $<2,105$ \\
\hline S96T005956 & $177: 5$ & Upper half & $<2,190$ & $<2,140$ & $<2,165$ \\
\hline S96T005957 & & Lower half & $<2,250$ & $<2,110$ & $<2,180$ \\
\hline S96T005934 & 177: 6 & Lower half & $<2,160$ & $<2,200$ & $<2,180$ \\
\hline
\end{tabular}


Table B2-15. Tank 241-BY-112 Analytical Results: Cerium (ICP).

\begin{tabular}{|c|c|c|c|c|c|}
\hline Simme & S. & 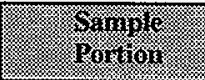 & merinis & Buplingur & 11/2ra \\
\hline Y) & & & .8. & 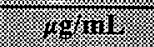 & 8.9 .11 \\
\hline S96T005907 & $174: 5$ & Drainable liquid & $<60.1$ & $<60.1$ & $<60.1$ \\
\hline S96T005960 & $177: 5$ & Drainable liquid & $<60.1$ & $<60.1$ & $<60.1$ \\
\hline 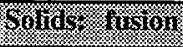 & 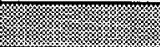 & (:> & . $19 \mathrm{gg}$ & .1998 & 148.9 \\
\hline S96T005889 & 174: 1 & Lower half & $<2,110$ & $<1,970$ & $<2,040$ \\
\hline S96T005890 & 174: 2 & Lower half & $<1,960$ & $<1,920$ & $<1,940$ \\
\hline S96T005891 & $174: 3$ & Lower half & $<1,960$ & $<2,180$ & $<2,070$ \\
\hline S96T005892 & 174: 4 & Lower half & $<1,960$ & $<1,840$ & $<1,900$ \\
\hline S96T005894 & \multirow[t]{2}{*}{$174: 5$} & Upper half & $<2,120$ & $<1,970$ & $<2,045$ \\
\hline S96T005893 & & Lower half & $<2,000$ & $<2,010$ & $<2,005$ \\
\hline S96T005896 & \multirow[t]{2}{*}{$174: 6$} & Upper half & $<2,030$ & $<2,010$ & $<2,020$ \\
\hline S96T005895 & & Lower half & $<2,050$ & $<2,240$ & $<2,145$ \\
\hline S96T005929 & 177: 1 & Lower half & $<1,990$ & $<1,860$ & $<1,925$ \\
\hline S96T005930 & 177: 2 & Lower half & $<1,910$ & $<1,860$ & $<1,885$ \\
\hline S96T005931 & $177: 3$ & Lower half & $<1,850$ & $<2,090$ & $<1,970$ \\
\hline S96T005932 & \multirow[t]{2}{*}{$177: 4$} & Upper half & $<2,050$ & $<1,980$ & $<2,015$ \\
\hline S96T005933 & & Lower half & $<2,130$ & $<2,080$ & $<2,105$ \\
\hline S96T005956 & \multirow[t]{2}{*}{$177: 5$} & Upper half & $<2,190$ & $<2,140$ & $<2,165$ \\
\hline S96T005957 & & Lower half & $<2,250$ & $<2,110$ & $<2,180$ \\
\hline S96T005934 & 177: 6 & Lower half & $<2,160$ & $<2,200$ & $<2,180$ \\
\hline
\end{tabular}


Table B2-16. Tank 241-BY-112 Analytical Results: Chromium (ICP).

\begin{tabular}{|c|c|c|c|c|c|}
\hline 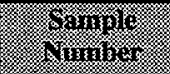 & 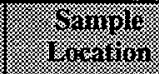 & Sominger & (1) & (Minilining & 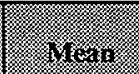 \\
\hline Yirining & & 8 & (7) & 8 . & $169+11$ \\
\hline S96T005907 & $174: 5$ & Drainable liquid & 8,820 & 8,840 & 8,830 \\
\hline S96T005960 & $177: 5$ & Drainable liquid & 13,200 & 13,300 & $13,250^{\mathrm{QC:c}}$ \\
\hline 561 ds & & 20 & . & 1.88 & 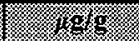 \\
\hline S96T005889 & $174: 1$ & Lower half & 4,640 & 4,610 & 4,625 \\
\hline S96T005890 & $174: 2$ & Lower half & 9,530 & 8,780 & 9,155 \\
\hline S96T005891 & 174: 3 & Lower half & 13,100 & 14,900 & 14,000 \\
\hline S96T005892 & 174: 4 & Lower half & 47,600 & 49,000 & 48,300 \\
\hline S96T005894 & \multirow[t]{2}{*}{$174: 5$} & Upper half & 26,700 & 29,200 & 27,950 \\
\hline S96T005893 & & Lower half & 19,500 & 15,700 & $17,600^{Q \mathrm{C}: \bullet}$ \\
\hline S96T005896 & \multirow[t]{2}{*}{$174: 6$} & Upper half & 9,080 & 8,950 & 9,015 \\
\hline S96T005895 & & Lower half & 3,830 & 3,650 & 3,740 \\
\hline S96T005929 & 177: 1 & Lower half & 4,700 & 4,380 & 4,540 \\
\hline S96T005930 & 177: 2 & Lower half & 6,200 & 6,120 & 6,160 \\
\hline S96T005931 & $177: 3$ & Lower half & 9,700 & 8,700 & 9,200 \\
\hline S96T005932 & \multirow[t]{2}{*}{$177: 4$} & Upper half & 25,500 & 24,900 & 25,200 \\
\hline S96T005933 & & Lower half & 47,400 & 43,900 & 45,650 \\
\hline S96T005956 & \multirow[t]{2}{*}{$177: 5$} & Upper half & 37,500 & 35,300 & 36,400 \\
\hline S96T005957 & & Lower half & 21,000 & 19,100 & 20,050 \\
\hline S96T005934 & $177: 6$ & Lower half & 13,800 & 14,000 & 13,900 \\
\hline
\end{tabular}


Table B2-17. Tank 241-BY-112 Analytical Results: Cobalt (ICP).

\begin{tabular}{|c|c|c|c|c|c|}
\hline - 4 ininiver & Sampl & $\begin{array}{l}\text { Sample } \\
\text { yout ron }\end{array}$ & nestitis & 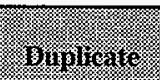 & $118 \mathrm{an}$ \\
\hline 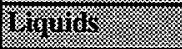 & (2) & 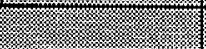 & 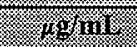 & $1.69 \mathrm{nill}$ & Wotrin \\
\hline S96T005907 & $174: 5$ & Drainable liquid & $<12$ & $<12$ & $<12$ \\
\hline S96T005960 & $177: 5$ & Drainable liquid & $<12$ & $<12$ & $<12$ \\
\hline \multicolumn{3}{|c|}{ Soldas } & 8.96 & 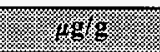 & 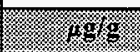 \\
\hline S96T005889 & 174: 1 & Lower half & $<421$ & $<395$ & $<408$ \\
\hline S96T005890 & $174: 2$ & Lower half & $<393$ & $<385$ & $<389$ \\
\hline S96T005891 & 174: 3 & Lower half & $<392$ & $<436$ & $<414$ \\
\hline S96T005892 & 174: 4 & Lower half & $<392$ & $<369$ & $<380.5$ \\
\hline S96T005894 & \multirow[t]{2}{*}{$174: 5$} & Upper half & $<425$ & $<395$ & $<410$ \\
\hline S96T005893 & & Lower half & $<399$ & $<401$ & $<400$ \\
\hline S96T005896 & \multirow[t]{2}{*}{$174: 6$} & Upper half & $<406$ & $<403$ & $<404.5$ \\
\hline S96T005895 & & Lower half & $<411$ & $<447$ & $<429$ \\
\hline S96T005929 & 177: 1 & Lower half & $<398$ & $<371$ & $<384.5$ \\
\hline S96T005930 & $177: 2$ & Lower half & $<381$ & $<373$ & $<377$ \\
\hline S96T005931 & $177: 3$ & Lower half & $<371$ & $<419$ & $<395$ \\
\hline S96T005932 & \multirow[t]{2}{*}{$177: 4$} & Upper half & $<409$ & $<395$ & $<402$ \\
\hline S96T005933 & & Lower half & $<425$ & $<415$ & $<420$ \\
\hline S96T005956 & \multirow[t]{2}{*}{$177: 5$} & Upper half & $<438$ & $<429$ & $<433.5$ \\
\hline S96T005957 & & Lower half & $<450$ & $<421$ & $<435.5$ \\
\hline S96T005934 & 177: 6 & Lower half & $<431$ & $<439$ & $<435$ \\
\hline
\end{tabular}




\begin{tabular}{|c|c|c|c|c|c|}
\hline $8 I Z>$ & $0 z z>$ & $9 I Z>$ & गाЕप دәмОТ & $9: \angle L I$ & $\nabla \varepsilon 6 \subseteq 00 \mathrm{~L} 96 \mathrm{~S}$ \\
\hline $8 I Z>$ & IIZ> & $s Z Z>$ & JाЕप г्мOT & \multirow[b]{2}{*}{$s: L L I$} & $\angle S 6 S 00 \mathrm{~L} 96 \mathrm{~S}$ \\
\hline s"9lz> & $t I Z>$ & $6 I Z>$ & गएеч Iadd & & 9S6S00L96S \\
\hline s.oIz> & $80 z>$ & $\varepsilon I Z>$ & Іеч гәмоТ & \multirow[b]{2}{*}{$\rightarrow: L L I$} & $\varepsilon \varepsilon 6 S 00 \mathrm{~L} 96 \mathrm{~S}$ \\
\hline sioz> & $86 I>$ & SOZ> & Iтеч radd & & $\tau \varepsilon 6 \$ 00 \mathrm{~L} 96 \mathrm{~S}$ \\
\hline$\angle 6 I>$ & $60 z>$ & $\mathrm{S} 8 \mathrm{I}>$ & Ітеप зәмот & $\varepsilon: L L I$ & I£6S00L96S \\
\hline$\varsigma^{\prime} 88 I>$ & $98 I>$ & I6I $>$ & ІІеप ЈәмОТ & $\tau: L L I$ & $0 \varepsilon 6 S 00196 \mathrm{~S}$ \\
\hline s.26I $>$ & $981>$ & $66 I>$ & गГЕЧ ऽәмОТ & $I: L L I$ & $626 S 00 \mathrm{~L} 96 \mathrm{~S}$ \\
\hline$s^{*}+\tau Z>$ & $\nabla z z>$ & soz> & Ј[Еप دәMOT] & \multirow[b]{2}{*}{$9: \nabla<I$} & S68S00L96S \\
\hline$z 0 \tau>$ & I0Z> & $\varepsilon 0 Z>$ & freप Iədd $\Omega$ & & 968S00L96S \\
\hline$s .00 z>$ & I0Z> & $00 z>$ & IRеप دәмо I & \multirow[b]{2}{*}{$s: t L I$} & E68S00L96S \\
\hline s.toz> & $L 6 I>$ & $z I z>$ & 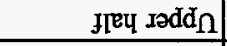 & & $\pm 68500.196 \mathrm{~S}$ \\
\hline $06 I>$ & $78 I>$ & $96 \llbracket>$ & झाеप дәMOT] & $\nabla: \nabla L I$ & $268500 \mathrm{I} 96 \mathrm{~S}$ \\
\hline LOZ> & $8 I Z>$ & $96 I>$ & J[Еप JәMO] & $\varepsilon: t \angle I$ & $168 S 00 \mathrm{~L} 96 \mathrm{~S}$ \\
\hline$+6 I>$ & $26 I>$ & $96 I>$ & УाЕप دәмоТ & $z: t<I$ & 068S00L96S \\
\hline toz> & $L 6 I>$ & IIZ> & J[Ец دәMOT] & $I: \nabla L I$ & $688 S 00 L 96 \mathrm{~S}$ \\
\hline 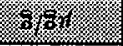 & 7fon: & 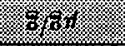 & স্য় & \multicolumn{2}{|c|}{ 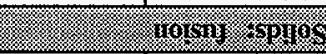 } \\
\hline I0.9> & $10.9>$ & $10.9>$ & 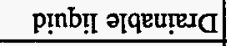 & $s: L L T$ & 096S00L96S \\
\hline $10^{\circ} 9>$ & I0.9> & $10.9>$ & p!nb!̣ ә әqеựexd & $s: \nabla L I$ & L06S00L $96 \mathrm{~S}$ \\
\hline 110 & 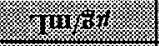 & 191\%\% & & & sountory \\
\hline 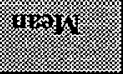 & 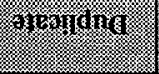 & 1962, & 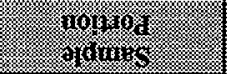 & 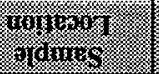 & 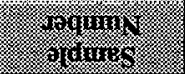 \\
\hline
\end{tabular}

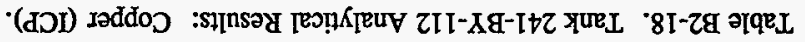




\begin{tabular}{|c|c|c|c|c|c|}
\hline$\varsigma \varepsilon 9^{\circ} z$ & $0 z s^{\prime} z$ & $0 S L^{\prime} Z$ & JГЕप गәмОТ & $9: L L I$ & tE6S00L96S \\
\hline $060^{\prime} I>$ & OSO $I>$ & $0 E I^{\prime} I>$ & Jएц Іәмот & \multirow[b]{2}{*}{$S: L L I$} & $\angle S 6 S 00 L 96 \mathrm{~S}$ \\
\hline$S 00^{\circ} \mathrm{s}$ & $00 I^{\prime} \mathrm{s}$ & $016^{6} t$ & jॅey Iədd $\Omega$ & & $9 \$ 6 S 00 \mathrm{~L} 96 \mathrm{~S}$ \\
\hline StI's & $086^{\circ} t$ & $0 I \varepsilon^{\prime} s$ & ЭГеप ЈәмО T & \multirow[b]{2}{*}{$D: L L I$} & Eع6S00L96S \\
\hline $0 \operatorname{OSc}^{4} \mathrm{~L}$ & $082^{6} \mathrm{I}$ & $0 z z^{6} \mathrm{I}$ & J[धч Iədd & & zE6S00L96S \\
\hline $886>$ & $0 \mathrm{SO}^{6} \mathrm{I}>$ & $926>$ & J[Еप ЈәмOT & $\varepsilon: L L I$ & IE6S00L96S \\
\hline$\tau \neq 6>$ & IE6> & $\varepsilon \$ 6>$ & माеप ІәмоТ & $\tau: L L I$ & $0 \varepsilon 6 \mathrm{~S} 00 \mathrm{~L} 96 \mathrm{~S}$ \\
\hline $0 I Z^{6} \varepsilon$ & $0 I \varepsilon^{\prime} \varepsilon$ & $0 I^{\prime} \mathcal{E}$ & Ғाеप ІәмО I & $I: L L I$ & $626 \mathrm{~S} 00 \mathrm{~L} 96 \mathrm{~S}$ \\
\hline $090^{\circ} \mathrm{L}$ & $006^{\prime} 9$ & $0 z z^{6} L$ & Jाеч ІәмоТ & \multirow[b]{2}{*}{$9: \mapsto \angle I$} & S68S00L96S \\
\hline SIO $\mathrm{I}>$ & $010^{6} \mathrm{~T}>$ & $020^{6} I>$ & न[еप radd & & $968 \mathrm{~S} 00\llcorner 96 \mathrm{~S}$ \\
\hline$: 00$ OSI'I> & $000^{\circ} I>$ & $00 \varepsilon^{\prime} T$ & नlеप Іәмот & \multirow[b]{2}{*}{$s: \mapsto L I$} & E68S00L96S \\
\hline$\$ 69^{\circ} \varepsilon$ & $000^{6} t$ & $06 \varepsilon^{\circ} \varepsilon$ & J[ष्प Jədd & & $768500 L 96 S$ \\
\hline $2: 50 S I E ' L$ & $0 z z^{\prime} 8$ & 0It'9 & माеप IәмOT & $t: t L I$ & $268500.196 \mathrm{~S}$ \\
\hline$S^{\prime}+\varepsilon 0^{\prime} I>$ & $060^{\circ} \mathrm{I}>$ & $6 L 6>$ & झाеч Іәмоі & $\varepsilon: \mapsto L I$ & I68S00L96S \\
\hline$\tau<6>$ & $296>$ & $286>$ & fाEप IәMOT & $\tau: t L I$ & $068 \mathrm{~S} 00 \mathrm{~L} 96 \mathrm{~S}$ \\
\hline$\therefore: 00$ SI 65 & $09 s^{\prime} s$ & $0 L \tau^{\prime} t$ & नाеч гәмот & $I: \oplus L I$ & $688 S 00 L 96 \mathrm{~S}$ \\
\hline (ingris & 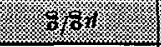 & 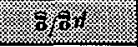 & 8 & \multicolumn{2}{|c|}{ 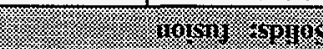 } \\
\hline$I 0 \varepsilon>$ & $I 0 \varepsilon>$ & $I 0 \varepsilon>$ & 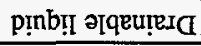 & $s: L L I$ & $096 \mathrm{~S} 00 \mathrm{~L} 96 \mathrm{~S}$ \\
\hline$I^{\circ} 0 \varepsilon>$ & I.0 $0 \varepsilon>$ & {$[0 \varepsilon>$} & 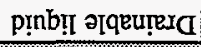 & $s: t L I$ & L06S00II96S \\
\hline Intixy & 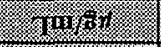 & 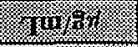 & & \multicolumn{2}{|c|}{ 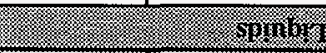 } \\
\hline 40 & 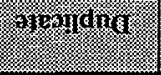 & II & 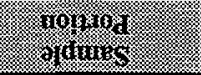 & 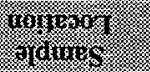 & $\begin{array}{l}\text { rogiring } \\
\text { ofings }\end{array}$ \\
\hline
\end{tabular}

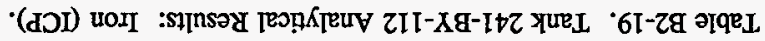


Table B2-20. Tank 241-BY-112 Analytical Results: Lanthanum (ICP).

\begin{tabular}{|c|c|c|c|c|c|}
\hline 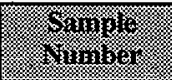 & 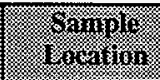 & 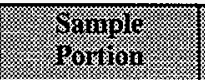 & Nosin! & Oingingute & 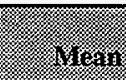 \\
\hline Givintid & : & 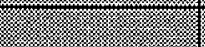 & 109 & 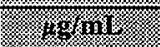 & $18.6 \%$ \\
\hline S96T005907 & $174: 5$ & Drainable liquid & $<30.1$ & $<30.1$ & $<30.1$ \\
\hline S96T005960 & $177: 5$ & Drainable liquid & $<30.1$ & $<30.1$ & $<30.1$ \\
\hline 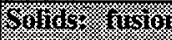 & & & $18 \mathrm{~g} / \mathrm{g}$ & 1.898 & (1) \\
\hline S96T005889 & 174: 1 & Lower half & $<1,050$ & $<987$ & $<1,018.5$ \\
\hline S96T005890 & $174: 2$ & Lower half & $<982$ & $<962$ & $<972$ \\
\hline S96T005891 & 174: 3 & Lower half & $<979$ & $<1,090$ & $<1,034.5$ \\
\hline S96T005892 & 174: 4 & Lower half & $<981$ & $<922$ & $<951.5$ \\
\hline \$96T005894 & $174: 5$ & Upper half & $<1,060$ & $<987$ & $<1,023.5$ \\
\hline S96T005893 & & Lower half & $<998$ & $<1,000$ & $<999$ \\
\hline S96T005896 & 174: 6 & Upper half & $<1,020$ & $<1,010$ & $<1,015$ \\
\hline S96T005895 & & Lower half & $<1,030$ & $<1,120$ & $<1,075$ \\
\hline S96T005929 & 177: 1 & Lower half & $<995$ & $<928$ & $<961.5$ \\
\hline S96T005930 & $177: 2$ & Lower half & $<953$ & $<931$ & $<942$ \\
\hline S96T005931 & $177: 3$ & Lower half & $<926$ & $<1,050$ & $<988$ \\
\hline S96T005932 & 177: 4 & Upper half & $<1,020$ & $<988$ & $<1,004$ \\
\hline S96T005933 & & Lower half & $<1,060$ & $<1,040$ & $<1,050$ \\
\hline S96T005956 & $177: 5$ & Upper half & $<1,090$ & $<1,070$ & $<1,080$ \\
\hline S96T005957 & & Lower half & $<1,130$ & $<1,050$ & $<1,090$ \\
\hline S96T005934 & 177: 6 & Lower half & $<1,080$ & $<1,100$ & $<1,090$ \\
\hline
\end{tabular}


Table B2-21. Tank 241-BY-112 Analytical Results: Lead (ICP).

\begin{tabular}{|c|c|c|c|c|c|}
\hline 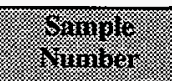 & 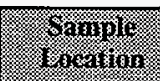 & 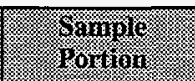 & Resulf & 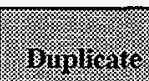 & 18 in \\
\hline Tyininis & 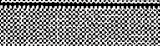 & " & (2. & 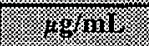 & 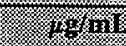 \\
\hline S96T005907 & $174: 5$ & Drainable liquid & $<60.1$ & $<60.1$ & $<60.1$ \\
\hline S96T005960 & $177: 5$ & Drainable liquid & $<60.1$ & $<60.1$ & $<60.1$ \\
\hline Solids fusion & & & (1) & 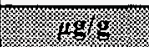 & (4) \\
\hline S96T005889 & 174: 1 & Lower half & $<2,110$ & $<1,970$ & $<2,040$ \\
\hline S96T005890 & $174: 2$ & Lower half & $<1,960$ & $<1,920$ & $<1,940$ \\
\hline S96T005891 & 174: 3 & Lower half & $<1,960$ & $<2,180$ & $<2,070$ \\
\hline S96T005892 & 174: 4 & Lower half & $<1,960$ & $<1,840$ & $<1,900$ \\
\hline S96T005894 & \multirow[t]{2}{*}{$174: 5$} & Upper half & $<2,120$ & $<1,970$ & $<2,045$ \\
\hline S96T005893 & & Lower half & $<2,000$ & $<2,010$ & $<2,005$ \\
\hline S96T005896 & \multirow[t]{2}{*}{$174: 6$} & Upper half & $<2,030$ & $<2,010$ & $<2,020$ \\
\hline S96T005895 & & Lower half & $<2,050$ & $<2,240$ & $<2,145$ \\
\hline S96T005929 & 177: 1 & Lower half & $<1,990$ & $<1,860$ & $<1,925$ \\
\hline S96T005930 & 177: 2 & Lower half & $<1,910$ & $<1,860$ & $<1,885$ \\
\hline S96T005931 & $177: 3$ & Lower half & $<1,850$ & $<2,090$ & $<1,970$ \\
\hline S96T005932 & \multirow[t]{2}{*}{$177: 4$} & Upper half & $<2,050$ & $<1,980$ & $<2,015$ \\
\hline S96T005933 & & Lower half & $<2,130$ & $<2,080$ & $<2,105$ \\
\hline S96T005956 & \multirow[t]{2}{*}{$177: 5$} & Upper half. & $<2,190$ & $<2,140$ & $<2,165$ \\
\hline S96T005957 & & Lower half & $<2,250$ & $<2,110$ & $<2,180$ \\
\hline S96T005934 & $177: 6$ & Lower half & $<2,160$ & $<2,200$ & $<2,180$ \\
\hline
\end{tabular}


Table B2-22. Tank 241-BY-112 Analytical Results: Lithium (ICP).

\begin{tabular}{|c|c|c|c|c|c|}
\hline 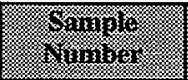 & 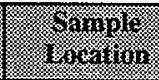 & Somple & Mesinti: & 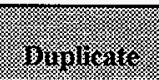 & (3) \\
\hline Eriginins & $\sqrt{-17}$ & $\sqrt{13}$ & (3. & 78, 311 . & 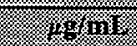 \\
\hline S96T005907 & $174: 5$ & Drainable liquid & $<6.01$ & $<6.01$ & $<6.01$ \\
\hline S96T005960 & $177: 5$ & Drainable liquid & $<6.01$ & $<6.01$ & $<6.01$ \\
\hline 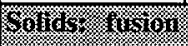 & , & : & 1898 & $1.98 \%$ & 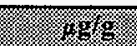 \\
\hline S96T005889 & 174: 1 & Lower half & $<211$ & $<197$ & $<204$ \\
\hline S96T005890 & $174: 2$ & Lower half & $<196$ & $<192$ & $<194$ \\
\hline S96T005891 & $174: 3$ & Lower half & $<196$ & $<218$ & $<207$ \\
\hline S96T005892 & 174: 4 & Lower half & $<196$ & $<184$ & $<190$ \\
\hline S96T005894 & $174: 5$ & Upper half & $<212$ & $<197$ & $<204.5$ \\
\hline S96T005893 & & Lower half & $<200$ & $<201$ & $<200.5$ \\
\hline S96T005896 & $174: 6$ & Upper half & $<203$ & $<201$ & $<202$ \\
\hline S96T005895 & & Lower half & $<205$ & $<224$ & $<214.5$ \\
\hline S96T005929 & $177: 1$ & Lower half & $<199$ & $<186$ & $<192.5$ \\
\hline S96T005930 & $177: 2$ & Lower half & $<191$ & $<186$ & $<188.5$ \\
\hline S96T005931 & $177: 3$ & Lower half & $<185$ & $<209$ & $<197$ \\
\hline \$96T005932 & $177: 4$ & Upper half & $<205$ & $<198$ & $<201.5$ \\
\hline S96T005933 & & Lower half & $<213$ & $<208$ & $<210.5$ \\
\hline S96T005956 & $177: 5$ & Upper half & $<219$ & $<214$ & $<216.5$ \\
\hline S96T005957 & & Lower half & $<225$ & $<211$ & $<218$ \\
\hline S96T005934 & $177: 6$ & Lower half & $<216$ & $<220$ & $<218$ \\
\hline
\end{tabular}


Table B2-23. Tank 241-BY-112 Analytical Results: Magnesium (ICP).

\begin{tabular}{|c|c|c|c|c|c|}
\hline 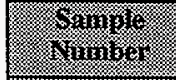 & Sompolo & $\begin{array}{l}\text { Sumple } \\
\text { Vortion }\end{array}$ & nesint & ionging & 318. \\
\hline 4iaidis & & & (1) & 18.90119 & $\sqrt{196 \mathrm{n} n \mathrm{I}}$ \\
\hline S96T005907 & $174: 5$ & Drainable liquid & $<60.1$ & $<60.1$ & $<60.1$ \\
\hline S96T005960 & $177: 5$ & Drainable liquid & $<60.1$ & $<60.1$ & $<60.1$ \\
\hline \multicolumn{2}{|l|}{ 6ondus fusion } & & (1) & 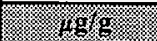 & 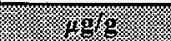 \\
\hline S96T005889 & 174: 1 & Lower half & $<2,110$ & $<1,970$ & $<2,040$ \\
\hline S96T005890 & 174: 2 & Lower half & $<1,960$ & $<1,920$ & $<1,940$ \\
\hline S96T005891 & $174: 3$ & Lower half & $<1,960$ & $<2,180$ & $<2,070$ \\
\hline S96T005892 & 174: 4 & Lower half & $<1,960$ & $<1,840$ & $<1,900$ \\
\hline S96T005894 & \multirow[t]{2}{*}{$174: 5$} & Upper half & $<2,120$ & $<1,970$ & $<2,045$ \\
\hline S96T005893 & & Lower half & $<2,000$ & $<2,010$ & $<2,005$ \\
\hline S96T005896 & \multirow[t]{2}{*}{$174: 6$} & Upper half & $<2,030$ & $<2,010$ & $<2,020$ \\
\hline S96T005895 & & Lower half & $<2,050$ & $<2,240$ & $<2,145$ \\
\hline S96T005929 & 177: 1 & Lower half & $<1,990$ & $<1,860$ & $<1,925$ \\
\hline S96T005930 & $177: 2$ & Lower half & $<1,910$ & $<1,860$ & $<1,885$ \\
\hline S96T005931 & $177: 3$ & Lower half & $<1,850$ & $<2,090$ & $<1,970$ \\
\hline S96T005932 & \multirow[t]{2}{*}{$177: 4$} & Upper half & $<2,050$ & $<1,980$ & $<2,015$ \\
\hline S96T005933 & & Lower half & $<2,130$ & $<2,080$ & $<2,105$ \\
\hline S96T005956 & \multirow[t]{2}{*}{$177: 5$} & Upper half & $<2,190$ & $<2,140$ & $<2,165$ \\
\hline S96T005957 & & Lower half & $<2,250$ & $<2,110$ & $<2,180$ \\
\hline S96T005934 & $177: 6$ & Lower half & $<2,160$ & $<2,200$ & $<2,180$ \\
\hline
\end{tabular}


HNF-SD-WM-ER-701 Rev. 0

Table B2-24. Tank 241-BY-112 Analytical Results: Manganese (ICP).

\begin{tabular}{|c|c|c|c|c|c|}
\hline Sininer: & s.m.10 & (1) & Iresint & Bimilicat & (19.8. \\
\hline \multicolumn{2}{|l|}{ Giginitis } & ; & 14.17il & 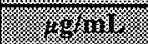 & $18 . \mathrm{m}$ \\
\hline S96T005907 & $174: 5$ & Drainable liquid & $<6.01$ & $<6.01$ & $<6.01$ \\
\hline S96T005960 & $177: 5$ & Drainable liquid & $<6.01$ & $<6.01$ & $<6.01$ \\
\hline \multicolumn{2}{|c|}{ 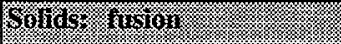 } & & 1 118.9 & 18.8 & : 1896 \\
\hline S96T005889 & 174: 1 & Lower half & $<211$ & $<197$ & $<204$ \\
\hline S96T005890 & 174: 2 & Lower half & $<196$ & $<192$ & $<194$ \\
\hline S96T005891 & $174: 3$ & Lower half & $<196$ & $<218$ & $<207$ \\
\hline S96T005892 & 174: 4 & Lower half & 686 & 793 & 739.5 \\
\hline S96T005894 & \multirow[t]{2}{*}{$174: 5$} & Upper half & 464 & 504 & 484 \\
\hline S96T005893 & & Lower half & 217 & $<201$ & $<209$ \\
\hline S96T005896 & \multirow[t]{2}{*}{ 174: 6} & Upper half & $<203$ & $<201$ & $<202$ \\
\hline S96T005895 & & Lower half & $<205$ & $<224$ & $<214.5$ \\
\hline S96T005929 & 177: 1 & Lower half & $<199$ & $<186$ & $<192.5$ \\
\hline S96T005930 & 177: 2 & Lower half & $<191$ & $<186$ & $<188.5$ \\
\hline S96T005931 & $177: 3$ & Lower half & $<185$ & $<209$ & $<197$ \\
\hline S96T005932 & \multirow[t]{2}{*}{$177: 4$} & Upper half & $<205$ & $<198$ & $<201.5$ \\
\hline S96T005933 & & Lower half & 550 & 515 & 532.5 \\
\hline S96T005956 & \multirow[t]{2}{*}{$177: 5$} & Upper half & 485 & 453 & 469 \\
\hline S96T005957 & & Lower half & $<225$ & $<211$ & $<218$ \\
\hline S96T005934 & 177: 6 & Lower half & $<216$ & $<220$ & $<218$ \\
\hline
\end{tabular}




\begin{tabular}{|c|c|c|c|c|c|}
\hline $060^{4} \tau>$ & $00 I^{\prime} \mathrm{I}>$ & $080^{\circ} \mathrm{I}>$ & ІाЕч मәмоТ & $9: L L I$ & $\pm \varepsilon 6 \mathrm{~S} 00 \mathrm{~L} 96 \mathrm{~S}$ \\
\hline $060^{\circ} I>$ & $\mathrm{OSO}^{6} \mathrm{I}>$ & $0 \varepsilon I^{\prime} I>$ & JТप ІәмОТ & \multirow[b]{2}{*}{$S: L L I$} & $\angle S 6 S 00 \mathrm{~L} 96 \mathrm{~S}$ \\
\hline $080^{\circ} I>$ & $0 \angle 0^{6} \mathrm{I}>$ & $060^{\circ} \mathrm{I}>$ & Jॉeч Iədd $n$ & & 9\$6S00L96S \\
\hline $0 S 0^{\circ} I>$ & $0+0^{6} \mathrm{I}>$ & $090^{\circ} \mathrm{I}>$ & IाЕप IЕМOT & \multirow[b]{2}{*}{$\downarrow: L L I$} & $\varepsilon \varepsilon 6 \mathrm{~S} 00 \mathrm{~L} 96 \mathrm{~S}$ \\
\hline$t 00^{\circ} I>$ & $886>$ & $020^{\circ}[>$ & गॉЕप Iədd $\Omega$ & & z\&6S00L96S \\
\hline $886>$ & $0 \mathrm{SO}^{5} \mathrm{I}>$ & $926>$ & JIEY IOMOT & $\varepsilon: L L I$ & IE6S00L96S \\
\hline $2 t 6>$ & IE6> & $\varepsilon S 6>$ & गएч хәмоТ & $2: L L I$ & $0 \varepsilon 6 \mathrm{~S} 00 \mathrm{~L} 96 \mathrm{~S}$ \\
\hline s.196> & $826>$ & $\subseteq 66>$ & Iाएч मәMO) & $I: L L I$ & $626 \mathrm{~S} 00 \mathrm{~L} 96 \mathrm{~S}$ \\
\hline$S L 0^{\prime} I>$ & $0 Z I^{\prime} I>$ & $0 E 0^{\circ} I>$ & गएе ІәмоТ & \multirow[b]{2}{*}{$9: \forall<I$} & S68S00L96S \\
\hline SIO'I & $010^{6} \mathrm{I}>$ & $0 Z 0^{6} I>$ & गएथ radd $\Omega$ & & $968 \mathrm{~S} 00 \mathrm{~L} 96 \mathrm{~S}$ \\
\hline $666>$ & $000^{6} I>$ & $866>$ & ІІеч дәмоТ & \multirow[b]{2}{*}{$s: t L I$} & $\varepsilon 68 \mathrm{~S} 00 \mathrm{~L} 96 \mathrm{~S}$ \\
\hline$S^{\bullet} \varepsilon Z 0^{\prime} I>$ & $\angle 86>$ & $090^{\circ} \mathrm{I}>$ & गाष्प मədd $\Omega$ & & $768500296 \mathrm{~S}$ \\
\hline S.IS6> & $226>$ & I86> & गाеч дәмОТ & $D: t L I$ & $268500 \mathrm{~L} 96 \mathrm{~S}$ \\
\hline$S^{\prime \prime}+\varepsilon 0^{4} I>$ & $060^{\circ} \mathrm{I}>$ & $6 L 6>$ & IाEप मәмОТ & $\varepsilon: t L I$ & I68S00L96S \\
\hline$\tau L 6>$ & $296>$ & $286>$ & गाएप IәмO I & $2: t L I$ & $068500 \mathrm{~L} 96 \mathrm{~S}$ \\
\hline$S^{\circ} 810^{6} I>$ & $\angle 86>$ & $0 S 0^{\circ}[>$ & Jृष دәMOT & $I: t L I$ & $688 \mathrm{~S} 00 L 96 \mathrm{~S}$ \\
\hline 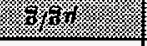 & ing & $8,6 \%$ & $\sqrt{4}$ & \multicolumn{2}{|c|}{ 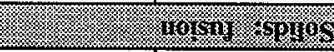 } \\
\hline$p=0 \$ 99^{\circ} 96$ & $\varepsilon<6$ & +6 & 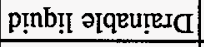 & $s: L L I$ & 096S00L96S \\
\hline$S L \cdot 66$ & $s^{\circ} 66$ & 001 & pụnb!̣ ə[qeu!̣eId & $s: t L I$ & L06S00.L96S \\
\hline 7nnory & 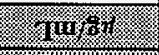 & [1m/6rit & & & s.ming \\
\hline 8ถ⿻上1) & Promang & 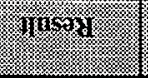 & $\begin{array}{l}\text { oofinot } \\
\text { porings }\end{array}$ & 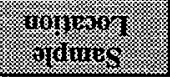 & gagumis \\
\hline
\end{tabular}

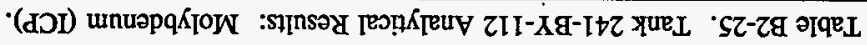


Table B2-26. Tank 241-BY-112 Analytical Results: Neodymium (ICP).

\begin{tabular}{|c|c|c|c|c|c|}
\hline viminis & Sarivif & Somole & iresin: & Iralingate & 14. \\
\hline Yiquins & : & ) & 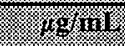 & (6) & (6) \\
\hline S96T005907 & $174: 5$ & Drainable liquid & $<60.1$ & $<60.1$ & $<60.1$ \\
\hline S96T005960 & $177: 5$ & Drainable liquid & $<60.1$ & $<60.1$ & $<60.1$ \\
\hline \multicolumn{2}{|l|}{ Golids finsion } & & (18gro & $4.4 \mathrm{~g}$ & $100 \mathrm{~g}$ \\
\hline S96T005889 & $174: 1$ & Lower half & $<2,110$ & $<1,970$ & $<2,040$ \\
\hline S96T005890 & 174: 2 & Lower half & $<1,960$ & $<1,920$ & $<1,940$ \\
\hline S96T005891 & 174: 3 & Lower half & $<1,960$ & $<2,180$ & $<2,070$ \\
\hline S96T005892 & 174: 4 & Lower half & $<1,960$ & $<1,840$ & $<1,900$ \\
\hline S96T005894 & \multirow[t]{2}{*}{$174: 5$} & Upper half & $<2,120$ & $<1,970$ & $<2,045$ \\
\hline S96T005893 & & Lower half & $<2,000$ & $<2,010$ & $<2,005$ \\
\hline S96T005896 & \multirow[t]{2}{*}{ 174: 6} & Upper half & $<2,030$ & $<2,010$ & $<2,020$ \\
\hline S96T005895 & & Lower half & $<2,050$ & $<2,240$ & $<2,145$ \\
\hline S96T005929 & 177: 1 & Lower half & $<1,990$ & $<1,860$ & $<1,925$ \\
\hline S96T005930 & $177: 2$ & Lower half & $<1,910$ & $<1,860$ & $<1,885$ \\
\hline S96T005931 & $177: 3$ & Lower half & $<1,850$ & $<2,090$ & $<1,970$ \\
\hline S96T005932 & \multirow[t]{2}{*}{$177: 4$} & Upper half & $<2,050$ & $<1,980$ & $<2,015$ \\
\hline S96T005933 & & Lower half & $<2,130$ & $<2,080$ & $<2,105$ \\
\hline S96T005956 & \multirow[t]{2}{*}{$177: 5$} & Upper half & $<2,190$ & $<2,140$ & $<2,165$ \\
\hline S96T005957 & & Lower half & $<2,250$ & $<2,110$ & $<2,180$ \\
\hline S96T005934 & $177: 6$ & Lower half & $<2,160$ & $<2,200$ & $<2,180$ \\
\hline
\end{tabular}


Table B2-27. Tank 241-BY-112 Analytical Results: Nickel (ICP).

\begin{tabular}{|c|c|c|c|c|c|}
\hline Thangle & 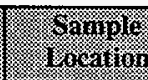 & Sompile & recsint & 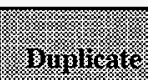 & . \\
\hline WGinas & $\sqrt{3.8}$ & & 493101 & 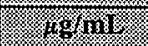 & 149,111 \\
\hline S96T005907 & $174: 5$ & Drainable liquid & $<12$ & $<12$ & $<12$ \\
\hline S96T005960 & $177: 5$ & Drainable liquid & $<12$ & $<12$ & $<12$ \\
\hline
\end{tabular}

Table B2-28. Tank 241-BY-112 Analytical Results: Phosphorus (ICP).

\begin{tabular}{|c|c|c|c|c|c|}
\hline Singer & Saruple & ivorition & result: & Briplicane & yera \\
\hline Wiguins & 40 & & $491 \mathrm{mI}=$ & tginl & $1,48.1011$ \\
\hline S96T005907 & $174: 5$ & Drainable liquid & 382 & 389 & 385.5 \\
\hline S96T005960 & $177: 5$ & Drainable liquid & 387 & 408 & $397.5^{\mathrm{QC:d}}$ \\
\hline \multicolumn{2}{|c|}{ 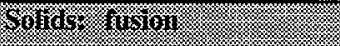 } & & 1898 & $8.14 \mathrm{gr}$ & 840 \\
\hline S96T005889 & 174: 1 & Lower half & 30,000 & 16,900 & $23,450^{\mathrm{QC:0}}$ \\
\hline S96T005890 & 174: 2 & Lower half & $<3,930$ & $<3,850$ & $<3,890$ \\
\hline S96T005891 & $174: 3$ & Lower half & $<3,920$ & 6,540 & $<5,230^{\mathrm{QC}: \mathrm{e}}$ \\
\hline S96T005892 & $174: 4$ & Lower half & 4,900 & $<3,690$ & $<4,295^{\text {Qc:e }}$ \\
\hline S96T005894 & \multirow[t]{2}{*}{$174: 5$} & Upper half & $<4,250$ & 5,660 & $<4,955^{\mathrm{QC:}: \mathrm{C}}$ \\
\hline S96T005893 & & Lower half & $<3,990$ & $<4,010$ & $<4,000$ \\
\hline S96T005896 & \multirow[t]{2}{*}{ 174: 6} & Upper half & $<4,060$ & $<4,030$ & $<4,045$ \\
\hline S96T005895 & & Lower half & $<4,110$ & $<4,470$ & $<4,290$ \\
\hline S96T005929 & 177: 1 & Lower half & 37,800 & 37,000 & 37,400 \\
\hline S96T005930 & $177: 2$ & Lower half & 7,890 & 4,010 & $5,950^{\mathrm{QC}: \mathrm{O}}$ \\
\hline S96T005931 & 177: 3 & Lower half & $<3,710$ & $<4,190$ & $<3,950$ \\
\hline S96T005932 & \multirow[t]{2}{*}{$177: 4$} & Upper half & $<4,090$ & $<3,950$ & $<4,020$ \\
\hline S96T005933 & & Lower half & $<4,250$ & $<4,150$ & $<4,200$ \\
\hline S96T005956 & \multirow[t]{2}{*}{$177: 5$} & Upper half & $<4,380$ & $<4,290$ & $<4,335$ \\
\hline S96T005957 & & Lower half & $<4,500$ & $<4,210$ & $<4,355$ \\
\hline S96T005934 & 177: 6 & Lower half & $<4,310$ & 7,700 & $<6,005^{\mathrm{Qc}: \mathrm{c}}$ \\
\hline
\end{tabular}


Table B2-29. Tank 241-BY-112 Analytical Results: Potassium (ICP).

\begin{tabular}{|c|c|c|c|c|c|}
\hline S) & gormen & Sromple & Resinil & 3) Holigate. & ifean \\
\hline 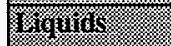 & & 8.8 & 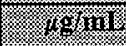 & Hown & 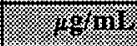 \\
\hline S96T005907 & $174: 5$ & Drainable liquid & 10,200 & 10,200 & 10,200 \\
\hline S96T005960 & $177: 5$ & Drainable liquid & 9,940 & 10,100 & $10,020^{\overline{Q C}: c}$ \\
\hline
\end{tabular}

Table B2-30. Tank 241-BY-112 Analytical Results: Samarium (ICP).

\begin{tabular}{|c|c|c|c|c|c|}
\hline Niningle & 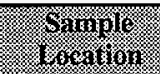 & Spample & resinit & Yiloborite & 2610 \\
\hline Siguras & & (2) & 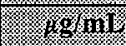 & m. & 1.9.1011 \\
\hline S96T005907 & $174: 5$ & Drainable liquid & $<60.1$ & $<60.1$ & $<60.1$ \\
\hline S96T005960 & $177: 5$ & Drainable liquid & $<60.1$ & $<60.1$ & $<60.1$ \\
\hline \multicolumn{2}{|l|}{ 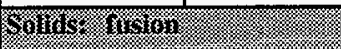 } & & 8.1848 & $68 \%$ & 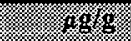 \\
\hline S96T005889 & 174: 1 & Lower half & $<2,110$ & $<1,970$ & $<2,040$ \\
\hline S96T005890 & 174: 2 & Lower half & $<1,960$ & $<1,920$ & $<1,940$ \\
\hline S96T005891 & $174: 3$ & Lower half & $<1,960$ & $<2,180$ & $<2,070$ \\
\hline S96T005892 & $174: 4$ & Lower half & $<1,960$ & $<1,840$ & $<1,900$ \\
\hline S96T005894 & \multirow[t]{2}{*}{$174: 5$} & Upper half & $<2,120$ & $<1,970$ & $<2,045$ \\
\hline S96T005893 & & Lower half & $<2,000$ & $<2,010$ & $<2,005$ \\
\hline S96T005896 & \multirow[t]{2}{*}{$174: 6$} & Upper half & $<2,030$ & $<2,010$ & $<2,020$ \\
\hline S96T005895 & & Lower half & $<2,050$ & $<2,240$ & $<2,145$ \\
\hline S96T005929 & 177: 1 & Lower half & $<1,990$ & $<1,860$ & $<1,925$ \\
\hline S96T005930 & 177: 2 & Lower half & $<1,910$ & $<1,860$ & $<1,885$ \\
\hline S96T005931 & $177: 3$ & Lower half & $<1,850$ & $<2,090$ & $<1,970$ \\
\hline S96T005932 & \multirow[t]{2}{*}{$177: 4$} & Upper half & $<2,050$ & $<1,980$ & $<2,015$ \\
\hline S96T005933 & & Lower half & $<2,130$ & $<2,080$ & $<2,105$ \\
\hline S96T005956 & \multirow[t]{2}{*}{$177: 5$} & Upper half & $<2,190$ & $<2,140$ & $<2,165$ \\
\hline S96T005957 & & Lower half & $<2,250$ & $<2,110$ & $<2,180$ \\
\hline S96T005934 & $177: 6$ & Lower half & $<2,160$ & $<2,200$ & $<2,180$ \\
\hline
\end{tabular}




\begin{tabular}{|c|c|c|c|c|c|}
\hline $08 I^{\prime} \tau>$ & $00 z^{\prime} z>$ & $09 I^{\prime} Z>$ & Iтеप دәMOI] & $9: \angle L I$ & $\downarrow \mathcal{E} 6 \mathrm{~S} 00 \mathrm{~L} 96 \mathrm{~S}$ \\
\hline $08 I^{6} z>$ & OII'Z> & $\operatorname{osz}^{\prime} \tau>$ & ІГеч хәмоТ] & \multirow[b]{2}{*}{$s: L L I$} & $\angle S 6 S 00196 S$ \\
\hline s9I' $2>$ & $0+I^{\prime} z>$ & $06 I^{\prime} \tau>$ & 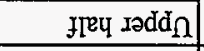 & & $9 S 6 S 00 \mathrm{~L} 96 \mathrm{~S}$ \\
\hline SOI' $z>$ & $080^{\circ} \mathrm{r}>$ & oEI' $\tau>$ & Іाеч دәмоТ & \multirow[b]{2}{*}{$\nabla: L L I$} & $\mathcal{E} 65 \mathrm{S00. \textrm {L } 9 6 \mathrm { S }}$ \\
\hline SI0'Z> & $086^{\circ} \mathrm{I}>$ & OSOC $z>$ & JाEY Iədd ח & & ¿E6S00LL6S \\
\hline $0 L 6^{4} I>$ & $060^{\circ} Z>$ & $058^{\prime} I>$ & รГеप دәмОТ & $\varepsilon: L L \mathrm{I}$ & IE6S00I96S \\
\hline$S 88^{6} I>$ & $098^{\prime} I>$ & $016^{6} โ>$ & ЭГеप ІәмоТ] & $\tau: L L I$ & $0 \varepsilon 6500.196 \mathrm{~S}$ \\
\hline$S 26^{6} \mathrm{I}>$ & $098^{\prime} I>$ & $066^{6} I>$ & माЕप دәMOT & $I: L L I$ & $626 \mathrm{~S} 00 \mathrm{LL} 9 \mathrm{~S}$ \\
\hline$s t I^{6} \imath>$ & $0+z^{6} z>$ & $00_{0}^{\circ} z>$ & ЭГеप دәмоТ & \multirow[b]{2}{*}{$9: \mapsto<I$} & S68S00I96S \\
\hline $0 z 0^{\circ} \tau>$ & $010^{6} \mathrm{z}>$ & $0 \varepsilon 0^{\prime} \tau>$ & 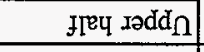 & & 968S00L96S \\
\hline $0 S 0^{\circ} \mathrm{Z}>$ & $010^{6} \mathrm{z}>$ & $060^{\circ} \mathrm{z}$ & गएч मәMO I & \multirow[b]{2}{*}{$s: t<I$} & $\varepsilon 68 \subseteq 00 \mathrm{~L} 96 \mathrm{~S}$ \\
\hline $0: 00066^{\circ} z$ & $099^{\circ} \varepsilon$ & $0 z \varepsilon^{\prime} z$ & Jाएч гәdd & & $\pm 68500 \mathrm{~L} 96 \mathrm{~S}$ \\
\hline $09 t^{4} 9$ & $08 I^{6} 9$ & $0+L^{\prime} 9$ & ITEY IOMOT & $t: \bullet L I$ & $268500 \mathrm{~L} 96 \mathrm{~S}$ \\
\hline $0<0^{6} z>$ & $08 I^{\prime} z>$ & $096^{6} I>$ & ІГеप ІәмOТ] & $\varepsilon: t<I$ & I68S00I96S \\
\hline $0 \pm 6^{6} \mathrm{I}>$ & $026^{\prime} I>$ & $096^{6} I>$ & JाЕप ІәмOТ] & $z: t<I$ & 068\$00L96S \\
\hline $0+0^{5} z>$ & $0 L 6^{6} I>$ & $0 I I^{6} Z>$ & ग[ЕЧ дәMOT] & $I: \forall \angle I$ & $688 S 00 \perp 96 S$ \\
\hline 8 & $7 \%$ & gifor & & \multicolumn{2}{|c|}{ nosvi } \\
\hline I.09> & $I^{\circ} 09>$ & {$[09>$} & 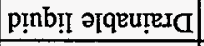 & $s: L L I$ & 096S00L96S \\
\hline$\quad \quad[09>$ & I.09> & $I \cdot 09>$ & p!̣nb!̣ әqеụฺesa & $s: t \angle I$ & $\angle 06 S 00 L 96 S$ \\
\hline aunging & parif & 4 & & & 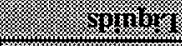 \\
\hline 48015 & 314notig & 11458 & vold & 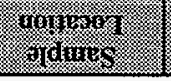 & - \\
\hline
\end{tabular}

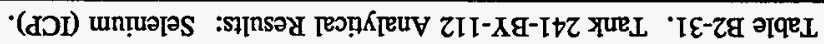




\begin{tabular}{|c|c|c|c|c|c|}
\hline $0 S t^{6} \varepsilon$ & $09 t^{6} \varepsilon$ & $0 t t^{6} \varepsilon$ & I[ЕЧ IәмOT & $9: L L I$ & $t \varepsilon 6 \mathrm{~S} 00 \mathrm{~L} 96 \mathrm{~S}$ \\
\hline SOI'I $>$ & $080^{\circ} \mathrm{I}$ & OEI'I> & J[Еप ІәмОТ & \multirow[b]{2}{*}{$s: L L I$} & $\angle S 6 S 00 L 96 \mathrm{~S}$ \\
\hline : & $O S 0^{\circ} \varepsilon$ & $08 \varepsilon^{\prime} z$ & fाeप Jәdd & & 9S6S00L $96 \mathrm{~S}$ \\
\hline$S \angle t^{\circ} \varepsilon$ & $0 L Z^{\prime} \varepsilon$ & $089^{\prime} \varepsilon$ & ҒाЕЧ ІәмОТ & \multirow[b]{2}{*}{$\downarrow: L L I$} & $\varepsilon \varepsilon 6 S 00 . \mathrm{L} 96 \mathrm{~S}$ \\
\hline :00SL9' I & $O S Z^{6} \mathrm{I}$ & $00 I^{\prime} z$ & नाеप Jәdd & & $\tau \varepsilon 6 \mathrm{~S} 00 \mathrm{~L} 96 \mathrm{~S}$ \\
\hline$:: 00<0+7$ & $08 I^{\prime} \mathrm{Z}$ & $09 L^{\circ} z$ & झाеप ІәмOT & $\varepsilon: L L I$ & I\&6S00L96S \\
\hline$s Z Z^{\prime} Z$ & $0 \angle Z^{6} z$ & $081^{\prime} z$ & झाषप ІәMOT & $Z: \angle L I$ & $0 \varepsilon 6 \mathrm{~S} 00 \mathrm{~L} 96 \mathrm{~S}$ \\
\hline $0 \varepsilon 6^{6} \mathrm{I}$ & $O L L^{6} T$ & $060^{\circ} \mathrm{z}$ & गाषप دәMOT & $I: L L I$ & $626 \mathrm{~S} 00 \mathrm{~L} 96 \mathrm{~S}$ \\
\hline $0 z \varepsilon^{\prime} s$ & $0 \varepsilon z^{6} s$ & OIt s & Ғाеप Іәмот & \multirow[b]{2}{*}{$9: \not L T$} & S68S00L96S \\
\hline SIO'I $>$ & OIO'I> & $0 z 0^{\circ} \mathrm{I}>$ & Jाеप ләdd & & $968500 \mathrm{~L} 96 \mathrm{~S}$ \\
\hline $0 S S^{\prime} \mathrm{I}$ & $0 E S^{\prime} I$ & $0 \angle S^{6} I$ & गТЕ ІәмОТ & \multirow[b]{2}{*}{$s: \nabla L I$} & $\varepsilon 68500 \mathrm{~L} 96 \mathrm{~S}$ \\
\hline : & $08 \varepsilon^{6} z$ & $0 E 8^{6} I$ & JाEप Iədd $\Omega$ & & t68S00L96S \\
\hline $0 z \varepsilon^{\prime} t$ & $0 S 96$ & $066^{\prime} \mathcal{E}$ & Ғ[ष् ІәмОТ & $t: t L I$ & Z68S00L96S \\
\hline$\because: 000 E 0^{\circ} z$ & $O Z L^{\prime} I$ & $0+\varepsilon^{\prime} z$ & गाЕप гәмот & $\varepsilon: \nabla L I$ & I68S00L96S \\
\hline $09 z^{6} \mathrm{I}$ & $0 z Z^{6} I$ & $00 \varepsilon^{\prime} \mathrm{I}$ & 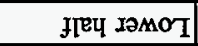 & $\tau: t L I$ & $068 S 00 \mathrm{~L} 96 \mathrm{~S}$ \\
\hline $06 I^{\prime} z$ & $0+I^{\prime} z$ & $0+z^{\prime} z$ & गुеч ІәмоТ & $I: t L I$ & 688S00L96S \\
\hline $67 x$ & 7. & 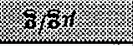 & (3) & \multicolumn{2}{|c|}{ 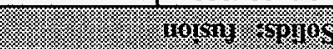 } \\
\hline p:oo\&6E & $08 \varepsilon$ & $90 t$ & 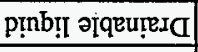 & $s: L L I$ & 096S00I. $96 \mathrm{~S}$ \\
\hline$s \cdot s+t$ & $\varepsilon S t$ & $8 \varepsilon t$ & pinbț әIqeựesa & $s: t L I$ & L06S00I96S \\
\hline $9 \operatorname{lng} 7 \%$ & 19umpry & ringir: & 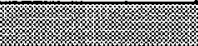 & & 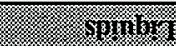 \\
\hline 18013 & 918916 ing & 11158d & 南 & angrorog. & orgurings: \\
\hline
\end{tabular}

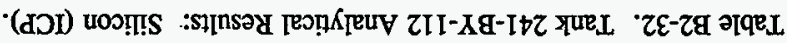


Table B2-33. Tank 241-BY-112 Analytical Results: Silver (ICP).

\begin{tabular}{|c|c|c|c|c|c|}
\hline Sinnings- & olomite & Samile & resul: & Hintivits & 6196an \\
\hline Ginings & & & (3) & $48 \mathrm{rnT}$ & (I) \\
\hline S96T005907 & $174: 5$ & Drainable liquid & 17.4 & 17.2 & 17.3 \\
\hline S96T005960 & $177: 5$ & Drainable liquid & 18 & 17.9 & 17.95 \\
\hline Sintids f fusion & (8) & & (6) & . & 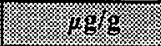 \\
\hline S96T005889 & 174: 1 & Lower half & $<211$ & $<197$ & $<204$ \\
\hline S96T005890 & $174: 2$ & Lower half & $<196$ & $<192$ & $<194^{\mathrm{QC}: \mathrm{c}}$ \\
\hline S96T005891 & 174: 3 & Lower half & $<196$ & $<218$ & $<207$ \\
\hline S96T005892 & 174: 4 & Lower half & $<196$ & $<184$ & $<190$ \\
\hline S96T005894 & \multirow[t]{2}{*}{$174: 5$} & Upper half & $<212$ & $<197$ & $<204.5$ \\
\hline S96T005893 & & Lower half & $<200$ & $<201$ & $<200.5$ \\
\hline S96T005896 & \multirow[t]{2}{*}{$174: 6$} & Upper half & $<203$ & $<201$ & $<202$ \\
\hline S96T005895 & & Lower half & $<205$ & $<224$ & $<214.5$ \\
\hline S96T005929 & 177: 1 & Lower half & $<199$ & $<186$ & $<192.5^{\mathrm{QC}: \mathrm{c}}$ \\
\hline S96T005930 & $177: 2$ & Lower half & $<191$ & $<186$ & $<188.5$ \\
\hline S96T005931 & $177: 3$ & Lower half & $<185$ & $<209$ & $<197$ \\
\hline S96T005932 & \multirow[t]{2}{*}{$177: 4$} & Upper half & $<205$ & $<198$ & $<201.5$ \\
\hline S96T005933 & & Lower half & $<213$ & $<208$ & $<210.5$ \\
\hline S96T005956 & \multirow[t]{2}{*}{$177: 5$} & Upper half & $<219$ & $<214$ & $<216.5$ \\
\hline S96T005957 & & Lower half & $<225$ & $<211$ & $<218$ \\
\hline S96T005934 & 177: 6 & Lower half & $<216$ & $<220$ & $<218$ \\
\hline
\end{tabular}


HNF-SD-WM-ER-701 Rev. 0

Table B2-34. Tank 241-BY-112 Analytical Results: Sodium (ICP).

\begin{tabular}{|c|c|c|c|c|c|}
\hline Vhangle & 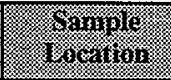 & 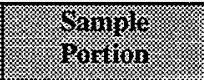 & Resuri: & Dingieare & gimen. \\
\hline Yyorat & & & 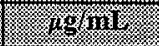 & W. & 694111 \\
\hline S96T005907 & $174: 5$ & Drainable liquid & $2.440 \mathrm{E}+05$ & $2.440 \mathrm{E}+05$ & $2.440 \mathrm{E}+05^{\mathrm{Cc}: \mathrm{c}}$ \\
\hline S96T005960 & $177: 5$ & Drainable liquid & $2.430 \mathrm{E}+05$ & $2.460 \mathrm{E}+05$ & $2.445 \mathrm{E}+05^{\mathrm{QC}: c}$ \\
\hline Soldis: fissin & & & 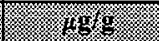 & 6796 & 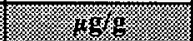 \\
\hline S96T005889 & 174: 1 & Lower half & $3.340 \mathrm{E}+05$ & $3.550 \mathrm{E}+05$ & $3.445 \mathrm{E}+05$ \\
\hline $896 \mathrm{~T} 005890$ & $174: 2$ & Lower half & $4.530 \mathrm{E}+05$ & $4.640 \mathrm{E}+05$ & $4.585 \mathrm{E}+05$ \\
\hline S96T005891 & $174: 3$ & Lower half & $4.520 \mathrm{E}+05$ & $4.350 \mathrm{E}+05$ & $4.435 E+05$ \\
\hline S96T005892 & $174: 4$ & Lower half & $3.420 \mathrm{E}+05$ & $3.770 \mathrm{E}+05$ & $3.595 \mathrm{E}+05$ \\
\hline S96T005894 & \multirow[t]{2}{*}{$174: 5$} & Upper half & $3.730 \mathrm{E}+05$ & $3.880 \mathrm{E}+05$ & $3.805 E+05$ \\
\hline S96T005893 & & Lower half & $3.330 \mathrm{E}+05$ & $3.350 \mathrm{E}+05$ & $3.340 \mathrm{E}+05$ \\
\hline S96T005896 & \multirow[t]{2}{*}{ 174: 6} & Upper half & $2.660 \mathrm{E}+05$ & $2.660 \mathrm{E}+05$ & $2.660 \mathrm{E}+05$ \\
\hline S96T005895 & & Lower half & $2.710 \mathrm{E}+05$ & $2.800 \mathrm{E}+05$ & $2.755 \mathrm{E}+05^{\mathrm{QC}: \mathrm{d}}$ \\
\hline S96T005929 & $177: 1$ & Lower half & $2.600 \mathrm{E}+05$ & $2.470 \mathrm{E}+05$ & $2.535 \mathrm{E}+05$ \\
\hline S96T005930 & $177: 2$ & Lower half & $3.290 \mathrm{E}+05$ & $3.330 \mathrm{E}+05$ & $3.310 \mathrm{E}+05$ \\
\hline S96T005931 & $177: 3$ & Lower half & $3.390 \mathrm{E}+05$ & $3.610 \mathrm{E}+05$ & $3.500 \mathrm{E}+05$ \\
\hline S96T005932 & \multirow[t]{2}{*}{$177: 4$} & Upper half & $3.230 \mathrm{E}+05$ & $3.040 \mathrm{E}+05$ & $3.135 \mathrm{E}+05^{\mathrm{QC}: c}$ \\
\hline S96T005933 & & Lower half & $2.650 \mathrm{E}+05$ & $2.720 \mathrm{E}+05$ & $2.685 E+05$ \\
\hline S96T005956 & \multirow[t]{2}{*}{$177: 5$} & Upper half & $2.730 \mathrm{E}+05$ & $2.740 \mathrm{E}+05$ & $2.735 \mathrm{E}+05$ \\
\hline S96T005957 & & Lower half & $2.730 \mathrm{E}+05$ & $2.680 \mathrm{E}+05$ & $2.705 E+05$ \\
\hline S96T005934 & 177: 6 & Lower half & $2.990 \mathrm{E}+05$ & $2.810 \mathrm{E}+05$ & $2.900 \mathrm{E}+05$ \\
\hline
\end{tabular}


Table B2-35. Tank 241-BY-112 Analytical Results: Strontium (ICP).

\begin{tabular}{|c|c|c|c|c|c|}
\hline - & 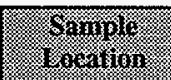 & Shaplf & tranil: & Bungueare & Mlyain \\
\hline K1 1 G & & & $180 . \mathrm{nI}$ & 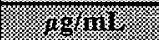 & 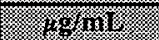 \\
\hline S96T005907 & $174: 5$ & Drainable liquid & $<6.01$ & $<6.01$ & $<6.01$ \\
\hline S96T005960 & $177: 5$ & Drainable liquid & $<6.01$ & $<6.01$ & $<6.01$ \\
\hline Soldidg Girsori & & : & ing & 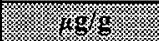 & 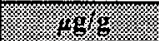 \\
\hline S96T005889 & 174: 1 & Lower half & $<211$ & 203 & $<207$ \\
\hline S96T005890 & 174: 2 & Lower half & $<196$ & $<192$ & $<194$ \\
\hline S96T005891 & $174: 3$ & Lower half & $<196$ & $<218$ & $<207$ \\
\hline S96T005892 & $174: 4$ & Lower half & $<196$ & $<184$ & $<190$ \\
\hline S96T005894 & \multirow[t]{2}{*}{$174: 5$} & Upper half & $<212$ & $<197$ & $<204.5$ \\
\hline S96T005893 & & Lower half & $<200$ & $<201$ & $<200.5$ \\
\hline S96T005896 & \multirow[t]{2}{*}{$174: 6$} & Upper half & $<203$ & $<201$ & $<202$ \\
\hline S96T005895 & & Lower half & $<205$ & $<224$ & $<214.5$ \\
\hline S96T005929 & 177: 1 & Lower half & $<199$ & $<186$ & $<192.5$ \\
\hline S96T005930 & $177: 2$ & Lower half & $<191$ & $<186$ & $<188.5$ \\
\hline S96T005931 & $177: 3$ & Lower half & $<185$ & $<209$ & $<197$ \\
\hline S96T005932 & \multirow[t]{2}{*}{$177: 4$} & Upper half & $<205$ & $<198$ & $<201.5$ \\
\hline S96T005933 & & Lower half & $<213$ & $<208$ & $<210.5$ \\
\hline S96T005956 & \multirow[t]{2}{*}{$177: 5$} & Upper half & $<219$ & $<214$ & $<216.5$ \\
\hline S96T005957 & & Lower half & $<225$ & $<211$ & $<218$ \\
\hline S96T005934 & $177: 6$ & Lower half & $<216$ & $<220$ & $<218$ \\
\hline
\end{tabular}


Table B2-36. Tank 241-BY-112 Analytical Results: Sulfur (ICP).

\begin{tabular}{|c|c|c|c|c|c|}
\hline raninger & S Saning & Sampile & Resintt & Binitats & trien. \\
\hline Givarits & ) & ls & S & is: & S \\
\hline S96T005907 & $174: 5$ & Drainable liquid & 331 & 328 & 329.5 \\
\hline S96T005960 & 177: 5 & Drainable liquid & 317 & 331 & $324^{\mathrm{C:}: \mathrm{d}}$ \\
\hline \multicolumn{2}{|l|}{ Shondis r gision } & & 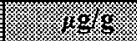 & . 18.9. & (3) \\
\hline S96T005889 & 174: 1 & Lower half & $<2,110$ & $<1,970$ & $<2,040$ \\
\hline S96T005890 & $174: 2$ & Lower half & 8,040 & 7,250 & 7,645 \\
\hline S96T005891 & $174: 3$ & Lower half & 5,870 & 7,010 & 6,440 \\
\hline S96T005892 & 174: 4 & Lower half & 15,500 & 15,500 & 15,500 \\
\hline S96T005894 & \multirow[t]{2}{*}{$174: 5$} & Upper half & 6,760 & 7,630 & 7,195 \\
\hline S96T005893 & & Lower half & 7,210 & 4,880 & $6,045^{\mathrm{QC}: e}$ \\
\hline S96T005896 & \multirow[t]{2}{*}{$174: 6$} & Upper half & 10,400 & 9,010 & 9,705 \\
\hline S96T005895 & & Lower half & 43,400 & 43,300 & 43,350 \\
\hline S96T005929 & 177: 1 & Lower half & $<1,990$ & $<1,860$ & $<1,925$ \\
\hline S96T005930 & 177: 2 & Lower half & 2,630 & 2,450 & 2,540 \\
\hline S96T005931 & $177: 3$ & Lower half & 2,210 & $<2,090$ & $<2,150$ \\
\hline S96T005932 & \multirow[t]{2}{*}{$177: 4$} & Upper half & 6,680 & 6,300 & 6,490 \\
\hline S96T005933 & & Lower half & 9,840 & 10,700 & 10,270 \\
\hline S96T005956 & \multirow[t]{2}{*}{$177: 5$} & Upper half & 6,190 & 5,770 & 5,980 \\
\hline S96T005957 & & Lower half & 4,380 & 4,130 & 4,255 \\
\hline S96T005934 & 177: 6 & Lower half & 24,100 & 28,400 & 26,250 \\
\hline
\end{tabular}


HNF-SD-WM-ER-701 Rev. 0

Table B2-37. Tank 241-BY-112 Analytical Results: Thallium (ICP).

\begin{tabular}{|c|c|c|c|c|c|}
\hline S & 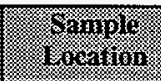 & Sample & 18 & Sypicste & $\sqrt{14}$ \\
\hline Serinitis: & 62 & (2) & (4) & 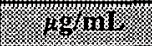 & 18.9610 \\
\hline S96T005907 & $174: 5$ & Drainable liquid & $<120$ & $<120$ & $<120$ \\
\hline S96T005960 & $177: 5$ & Drainable liquid & $<120$ & $<120$ & $<120$ \\
\hline Solide r Vusio & & & . 10.59 & 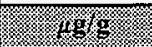 & 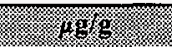 \\
\hline S96T005889 & 174: 1 & Lower half & $<4,210$ & $<3,950$ & $<4,080$ \\
\hline S96T005890 & $174: 2$ & Lower half & $<3,930$ & $<3,850$ & $<3,890$ \\
\hline S96T005891 & $174: 3$ & Lower half & $<3,920$ & $<4,360$ & $<4,140$ \\
\hline S96T005892 & $174: 4$ & Lower half & $<3,920$ & $<3,690$ & $<3,805$ \\
\hline S96T005894 & \multirow[t]{2}{*}{$174: 5$} & Upper half & $<4,250$ & $<3,950$ & $<4,100$ \\
\hline S96T005893 & & Lower half & $<3,990$ & $<4,010$ & $<4,000$ \\
\hline \$96T005896 & \multirow[t]{2}{*}{$174: 6$} & Upper half & $<4,060$ & $<4,030$ & $<4,045$ \\
\hline S96T005895 & & Lower half & $<4,110$ & $<4,470$ & $<4,290$ \\
\hline S96T005929 & 177: 1 & Lower half & $<3,980$ & $<3,710$ & $<3,845$ \\
\hline S96T005930 & $177: 2$ & Lower half & $<3,810$ & $<3,730$ & $<3,770$ \\
\hline S96T005931 & $177: 3$ & Lower half & $<3,710$ & $<4,190$ & $<3,950$ \\
\hline S96T005932 & \multirow[t]{2}{*}{$177: 4$} & Upper half & $<4,090$ & $<3,950$ & $<4,020$ \\
\hline S96T005933 & & Lower half & $<4,250$ & $<4,150$ & $<4,200$ \\
\hline S96T005956 & \multirow[t]{2}{*}{$177: 5$} & Upper half & $<4,380$ & $<4,290$ & $<4,335$ \\
\hline S96T005957 & & Lower half & $<4,500$ & $<4,210$ & $<4,355$ \\
\hline S96T005934 & $177: 6$ & Lower half & $<4,310$ & $<4,390$ & $<4,350$ \\
\hline
\end{tabular}


Table B2-38. Tank 241-BY-112 Analytical Results: Titanium (ICP).

\begin{tabular}{|c|c|c|c|c|c|}
\hline Giminger & 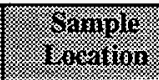 & Syortini & Resint & Binjucaro & 196. \\
\hline \multicolumn{3}{|l|}{ Yuring } & . & 196401 & 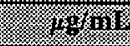 \\
\hline S96T005907 & $174: 5$ & Drainable liquid & $<6.01$ & $<6.01$ & $<6.01$ \\
\hline S96T005960 & $177: 5$ & Drainable liquid & $<6.01$ & $<6.01$ & $<6.01^{\mathrm{QC:d}}$ \\
\hline \multicolumn{2}{|l|}{ Solust 945013} & & $18 \%$ & . & 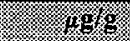 \\
\hline S96T005889 & 174: 1 & Lower half & $<211$ & $<197$ & $<204$ \\
\hline S96T005890 & 174: 2 & Lower half & $<196$ & $<192$ & $<194$ \\
\hline S96T005891 & 174: 3 & Lower half & $<196$ & $<218$ & $<207$ \\
\hline S96T005892 & 174: 4 & Lower half & $<196$ & $<184$ & $<190$ \\
\hline S96T005894 & \multirow[t]{2}{*}{$174: 5$} & Upper half & $<212$ & $<197$ & $<204.5$ \\
\hline S96T005893 & & Lower half & $<200$ & $<201$ & $<200.5$ \\
\hline S96T005896 & \multirow[t]{2}{*}{ 174: 6} & Upper half & $<203$ & $<201$ & $<202$ \\
\hline S96T005895 & & Lower half & $<205$ & $<224$ & $<214.5$ \\
\hline S96T005929 & 177: 1 & Lower half & $<199$ & $<186$ & $<192.5$ \\
\hline S96T005930 & 177: 2 & Lower half & $<191$ & $<186$ & $<188.5$ \\
\hline S96T005931 & 177: 3 & Lower half & $<185$ & $<209$ & $<197$ \\
\hline S96T005932 & \multirow[t]{2}{*}{ 177: 4} & Upper half & $<205$ & $<198$ & $<201.5$ \\
\hline S96T005933 & & Lower half & $<213$ & $<208$ & $<210.5$ \\
\hline S96T005956 & \multirow[t]{2}{*}{$177: 5$} & Upper half & $<219$ & $<214$ & $<216.5$ \\
\hline S96T005957 & & Lower half & $<225$ & $<211$ & $<218$ \\
\hline S96T005934 & 177: 6 & Lower half & $<216$ & $<220$ & $<218$ \\
\hline
\end{tabular}


HNF-SD-WM-ER-701 Rev. 0

Table B2-39. Tank 241-BY-112 Analytical Results: Total Uranium (ICP).

\begin{tabular}{|c|c|c|c|c|c|}
\hline 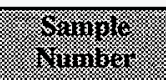 & Somplich & $\begin{array}{l}\text { Simple } \\
\text { Tourtor }\end{array}$ & resulit & Biniligerse & 31:an \\
\hline Minarias & (3: & 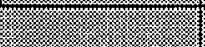 & 6.9.1111 & 186 init & 8.6111 \\
\hline S96T005907 & $174: 5$ & Drainable liquid & $<300$ & $<300$ & $<300$ \\
\hline S96T005960 & $177: 5$ & Drainable liquid & $<300$ & $<300$ & $<300$ \\
\hline Solios fusor & & 3 & 3.98 & 40 & 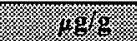 \\
\hline S96T005889 & 174: 1 & Lower half & $<10,500$ & $<9,870$ & $<10,185$ \\
\hline S96T005890 & $174: 2$ & Lower half & $<9,820$ & $<9,620$ & $<9,720$ \\
\hline S96T005891 & $174: 3$ & Lower half & $<9,790$ & $<10,900$ & $<10,345$ \\
\hline S96T005892 & 174: 4 & Lower half & $<9,810$ & $<9,220$ & $<9,515$ \\
\hline S96T005894 & \multirow[t]{2}{*}{$174: 5$} & Upper half & $<10,600$ & $<9,870$ & $<10,235$ \\
\hline S96T005893 & & Lower half & $<9,980$ & $<10,000$ & $<9,990$ \\
\hline S96T005896 & \multirow[t]{2}{*}{$174: 6$} & Upper half & $<10,200$ & $<10,100$ & $<10,150$ \\
\hline S96T005895 & & Lower half & $<10,300$ & $<11,200$ & $<10,750$ \\
\hline S96T005929 & 177: 1 & Lower half & $<9,950$ & $<9,280$ & $<9,615$ \\
\hline S96T005930 & $177: 2$ & Lower half & $<9,530$ & $<9,310$ & $<9,420$ \\
\hline S96T005931 & $177: 3$ & Lower half & $<9,260$ & $<10,500$ & $<9,880$ \\
\hline S96T005932 & \multirow[t]{2}{*}{$177: 4$} & Upper half & $<10,200$ & $<9,880$ & $<10,040$ \\
\hline S96T005933 & & Lower half & $<10,600$ & $<10,400$ & $<10,500$ \\
\hline S96T005956 & \multirow[t]{2}{*}{$177: 5$} & Upper half & $<10,900$ & $<10,700$ & $<10,800$ \\
\hline S96T005957 & & Lower half & $<11,300$ & $<10,500$ & $<10,900$ \\
\hline S96T005934 & $177: 6$ & Lower half & $<10,800$ & $<11,000$ & $<10,900$ \\
\hline
\end{tabular}


Table B2-40. Tank 241-BY-112 Analytical Results: Vanadium (ICP).

\begin{tabular}{|c|c|c|c|c|c|}
\hline Sininiles: & S Sampll: & Saminge & Pesill & Bunileats: & 14ar \\
\hline \multicolumn{3}{|l|}{ Yupinitis } & 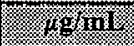 & $19.11 \%$ & 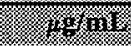 \\
\hline S96T005907 & $174: 5$ & Drainable liquid & $<30.1$ & $<30.1$ & $<30.1$ \\
\hline S96T005960 & $177: 5$ & Drainable liquid & $<30.1$ & $<30.1$ & $<30.1$ \\
\hline \multicolumn{3}{|c|}{ Solinis finsion } & 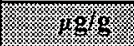 & (1) & 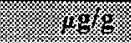 \\
\hline S96T005889 & 174: 1 & Lower half & $<1,050$ & $<987$ & $<1,018.5$ \\
\hline S96T005890 & $174: 2$ & Lower half & $<982$ & $<962$ & $<972$ \\
\hline S96T005891 & $174: 3$ & Lower half & $<979$ & $<1,090$ & $<1,034.5$ \\
\hline S96T005892 & $174: 4$ & Lower half & $<981$ & $<922$ & $<951.5$ \\
\hline S96T005894 & \multirow[t]{2}{*}{$174: 5$} & Upper half & $<1,060$ & $<987$ & $<1,023.5$ \\
\hline S96T005893 & & Lower half & $<998$ & $<1,000$ & $<999$ \\
\hline S96T005896 & \multirow[t]{2}{*}{ 174: 6} & Upper half & $<1,020$ & $<1,010$ & $<1,015$ \\
\hline S96T005895 & & Lower half & $<1,030$ & $<1,120$ & $<1,075$ \\
\hline S96T005929 & 177: 1 & Lower half & $<995$ & $<928$ & $<961.5$ \\
\hline S96T005930 & $177: 2$ & Lower half & $<953$ & $<931$ & $<942$ \\
\hline S96T005931 & $177: 3$ & Lower half & $<926$ & $<1,050$ & $<988$ \\
\hline S96T005932 & \multirow[t]{2}{*}{ 177: 4} & Upper half & $<1,020$ & $<988$ & $<1,004$ \\
\hline S96T005933 & & Lower half & $<1,060$ & $<1,040$ & $<1,050$ \\
\hline S96T005956 & \multirow[t]{2}{*}{$177: 5$} & Upper half & $<1,090$ & $<1,070$ & $<1,080$ \\
\hline S96T005957 & & Lower half & $<1,130$ & $<1,050$ & $<1,090$ \\
\hline S96T005934 & 177: 6 & Lower half & $<1,080$ & $<1,100$ & $<1,090$ \\
\hline
\end{tabular}




\begin{tabular}{|c|c|c|c|c|c|}
\hline $812>$ & $0 z z>$ & $9 I z>$ & IREप IOMOT & $9: L L I$ & $\downarrow \varepsilon 6 \mathrm{~S} 00 \mathrm{~L} 96 \mathrm{~S}$ \\
\hline $8 \mathrm{I} Z>$ & IIZ> & $s \tau z>$ & ІГеч ІәмоТ & \multirow[b]{2}{*}{$\S: L L I$} & $\angle S 6 S 00 \mathrm{~L} 96 \mathrm{~S}$ \\
\hline s.9Iz> & $t I Z>$ & $6 \mathrm{I} Z>$ & IreY radd $\Omega$ & & $9 S 6 S 00 \mathrm{~L} 96 \mathrm{~S}$ \\
\hline s.0Iz> & $80 z>$ & $\varepsilon I \tau>$ & J[Еप دәмОТ & \multirow[b]{2}{*}{$\nabla: L L I$} & $\varepsilon \varepsilon 6 \mathrm{~S} 00 \mathrm{~L} 96 \mathrm{~S}$ \\
\hline s.10z> & $86 I>$ & soz> & 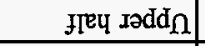 & & $2 \varepsilon 6 \mathrm{~S} 00 \mathrm{I} 96 \mathrm{~S}$ \\
\hline$\angle 6 I>$ & $60 z>$ & $58 \mathrm{I}>$ & ІГеप دәмо T & $\varepsilon: L L I$ & IE6S00J96S \\
\hline$S \cdot 88 \mathrm{I}>$ & $98 \mathrm{I}>$ & I6I> & JГЕЧ ІәMOT & $\tau: L L I$ & $0 \varepsilon 6 \mathrm{~S} 00 \perp 96 \mathrm{~S}$ \\
\hline $\mathrm{s}^{\prime} 26 \mathrm{I}>$ & $98 \mathrm{I}>$ & $66 I>$ & 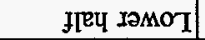 & $I: L L I$ & $626 \mathrm{~S} 00 \mathrm{~L} 96 \mathrm{~S}$ \\
\hline$s^{*}+[\tau>$ & $t z z>$ & soz> & ҒГеप ІәмОТ & \multirow[b]{2}{*}{$9: t<I$} & S68S00LI96S \\
\hline$z 0 z>$ & $I 0 Z>$ & $\varepsilon 0 \tau>$ & JाEY rədd & & $968 S 00 \mathrm{~L} 96 \mathrm{~S}$ \\
\hline s.00z> & I0Z> & $00 z>$ & IГеप гәмоТ] & \multirow[b]{2}{*}{$s: t L I$} & $\mathcal{E} 68500 \mathrm{r} 96 \mathrm{~S}$ \\
\hline $0: 00<Z \varepsilon>$ & $2 t t$ & $Z I Z>$ & Jreप Jədd & & $+68 S 00196 \mathrm{~S}$ \\
\hline $0: 00<I \varepsilon>$ & $8 E t$ & $96 \mathrm{I}>$ & झाषप IәMOT & $t: t L I$ & $z 68 S 00 \perp 96 S$ \\
\hline$: 00892>$ & $8 \mathrm{I} Z>$ & $8 \mathrm{IE}$ & गाЕप ІәмOT & $\varepsilon: \nabla L I$ & $168500196 \mathrm{~S}$ \\
\hline$\$ 6 I>$ & $26 \mathrm{I}>$ & $96 I>$ & ЭГеч ІәмОТ & $\tau: \forall L I$ & $068 \mathrm{~S} 00 \mathrm{~L} 96 \mathrm{~S}$ \\
\hline$\neq 0 z>$ & $\angle 6 \mathrm{I}\rangle$ & IIZ> & Ғाеч Іәмот & $I: t L I$ & $688 \mathrm{~S} 00 \mathrm{~L} 96 \mathrm{~S}$ \\
\hline 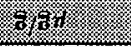 & 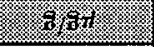 & 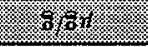 & & \multicolumn{2}{|c|}{ 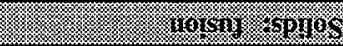 } \\
\hline $10^{\circ} 9>$ & $10.9>$ & $10.9>$ & pinb!n әqеuाesa & $S: L L I$ & $096500 \mathrm{~L} 96 \mathrm{~S}$ \\
\hline $10.9>$ & $10^{\circ} 9>$ & $10.9>$ & 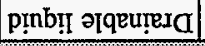 & $s: t L I$ & L06S00L96S \\
\hline 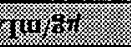 & yortor & lumb & f & & 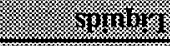 \\
\hline 9819 & Pugriming & $\sqrt[3115908]{ }$ & 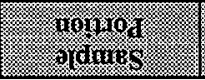 & : & 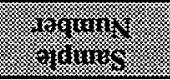 \\
\hline
\end{tabular}

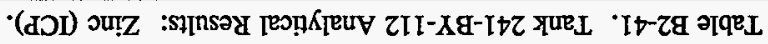


Table B2-42. Tank 241-BY-112 Analytical Results: Zirconium (ICP).

\begin{tabular}{|c|c|c|c|c|c|}
\hline 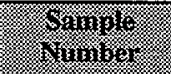 & o. & Suminer & icsint & 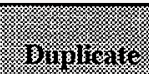 & 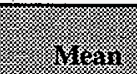 \\
\hline \multicolumn{2}{|l|}{ Yirings: } & 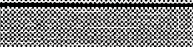 & $.961 \mathrm{~min}$ & 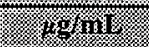 & 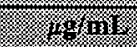 \\
\hline S96T005907 & $174: 5$ & Drainable liquid & $<6.01$ & $<6.01$ & $<6.01$ \\
\hline S96T005960 & $177: 5$ & Drainable liquid & $<6.01$ & $<6.01$ & $<6.01^{\mathrm{QC}: \mathrm{d}}$ \\
\hline \multicolumn{2}{|l|}{ 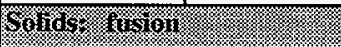 } & (1) & mg & (2) & (1) \\
\hline S96T005889 & 174: 1 & Lower half & $<211$ & $<197$ & $<204$ \\
\hline S96T005890 & $174: 2$ & Lower half & $<196$ & $<192$ & $<194$ \\
\hline S96T005891 & $174: 3$ & Lower half & $<196$ & $<218$ & $<207$ \\
\hline S96T005892 & $174: 4$ & Lower half & $<196$ & $<184$ & $<190$ \\
\hline S96T005894 & \multirow[t]{2}{*}{$174: 5$} & Upper half & $<212$ & $<197$ & $<204.5$ \\
\hline S96T005893 & & Lower half & $<200$ & $<201$ & $<200.5$ \\
\hline S96T005896 & \multirow[t]{2}{*}{$174: 6$} & Upper half & $<203$ & $<201$ & $<202$ \\
\hline S96T005895 & & Lower half & $<205$ & $<224$ & $<214.5$ \\
\hline S96T005929 & $177: 1$ & Lower half & $<199$ & $<186$ & $<192.5$ \\
\hline S96T005930 & $177: 2$ & Lower half & $<191$ & $<186$ & $<188.5$ \\
\hline S96T005931 & $177: 3$ & Lower half & $<185$ & $<209$ & $<197$ \\
\hline S96T005932 & \multirow[t]{2}{*}{$177: 4$} & Upper half & $<205$ & $<198$ & $<201.5$ \\
\hline S96T005933 & & Lower half & $<213$ & $<208$ & $<210.5$ \\
\hline S96T005956 & \multirow[t]{2}{*}{$177: 5$} & Upper half & $<219$ & $<214$ & $<216.5$ \\
\hline S96T005957 & & Lower half & $<225$ & $<211$ & $<218$ \\
\hline S96T005934 & $177: 6$ & Lower half & $<216$ & $<220$ & $<218$ \\
\hline
\end{tabular}


Table B2-43. Tank 241-BY-112 Analytical Results: Bromide (IC).

\begin{tabular}{|c|c|c|c|c|c|}
\hline S Sininger & $\begin{array}{l}\text { Shample } \\
\text { - }\end{array}$ & - Sample & Riesint: & 3ymingerto & (6) \\
\hline \multicolumn{3}{|c|}{ 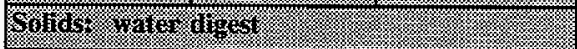 } & (3) & 196 & 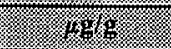 \\
\hline S96T005897 & 174: 1 & Lower half & 466.5 & 402 & 434.25 \\
\hline S96T005898 & 174: 2 & Lower half & $<265.3$ & $<283$ & $<274.15$ \\
\hline S96T005899 & $174: 3$ & Lower half & $<266$ & $<281$ & $<273.5$ \\
\hline S96T005900 & 174: 4 & Lower half & $<24.53$ & $<546$ & $<285.265^{\mathrm{QC}: \theta}$ \\
\hline S96T005902 & \multirow[t]{2}{*}{$174: 5$} & Upper half & $<512$ & $<546$ & $<529$ \\
\hline S96T005901 & & Lower half & $<24.65$ & $<24.9$ & $<24.775$ \\
\hline S96T005904 & \multirow[t]{2}{*}{$174: 6$} & Upper half & $<905.3$ & $<1,040$ & $<972.65$ \\
\hline S96T005903 & & Lower half & $<2,598$ & $<2,530$ & $<2,564$ \\
\hline S96T005935 & 177: 1 & Lower half & $<956.3$ & $<1,020$ & $<988.15$ \\
\hline S96T005936 & 177: 2 & Lower half & $<929.5$ & $<982$ & $<955.75$ \\
\hline S96T005937 & $177: 3$ & Lower half & $<1,051$ & $<952$ & $<1,001.5$ \\
\hline S96T005938 & \multirow[t]{2}{*}{ 177: 4} & Upper half & $<262.9$ & $<271$ & $<266.95$ \\
\hline S96T005939 & & Lower half & $<518.1$ & $<511$ & $<514.55$ \\
\hline S96T005958 & \multirow[t]{2}{*}{$177: 5$} & Upper half & $<554.9$ & $<542$ & $<548.45$ \\
\hline S96T005959 & & Lower half & $<1,078$ & $<1,030$ & $<1,054$ \\
\hline S96T005940 & $177: 6$ & Lower half & $<1,049$ & $<981$ & $<1,015$ \\
\hline Wringids & 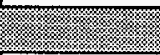 & & 8.969 .111 & $.1091 \mathrm{mi}$ & (19.1m \\
\hline S96T005907 & $174: 5$ & Drainable liquid & $<1,275$ & $<1,280$ & $<1,277.5$ \\
\hline S96T005960 & $177: 5$ & Drainable liquid & $<643.9$ & $<644$ & $<643.95$ \\
\hline
\end{tabular}


Table B2-44. Tank 241-BY-112 Analytical Results: Chloride (IC).

\begin{tabular}{|c|c|c|c|c|c|}
\hline Sonnoles & 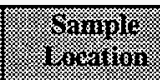 & $\begin{array}{l}\text { Shingle } \\
\text { Trowtion }\end{array}$ & Resul: & Bumilieare & 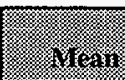 \\
\hline \multicolumn{3}{|c|}{ 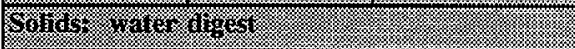 } & 8 \% $5 \%$ & 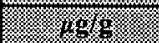 & 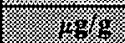 \\
\hline S96T005897 & 174: 1 & Lower half & 268.1 & 211 & $239.55^{\mathrm{QC}: \mathrm{e}}$ \\
\hline S96T005898 & 174: 2 & Lower half & 171.3 & 188 & 179.65 \\
\hline S96T005899 & $174: 3$ & Lower half & 245.3 & 331 & $288.15^{\mathrm{QC}: 0}$ \\
\hline S96T005900 & 174: 4 & Lower half & 772.9 & 1,190 & $981.45^{\mathrm{QC:e}}$ \\
\hline S96T005902 & \multirow[t]{2}{*}{$174: 5$} & Upper half & 2,083 & 2,170 & $2,126.5$ \\
\hline S96T005901 & & Lower half & 52.86 & 115 & $83.93^{\mathrm{QC:0}}$ \\
\hline S96T005904 & \multirow[t]{2}{*}{$174: 6$} & Upper half & 2,944 & 3,460 & 3,202 \\
\hline S96T005903 & & Lower half & 3,072 & 3,080 & 3,076 \\
\hline S96T005935 & 177: 1 & Lower half & 372.5 & 395 & 383.75 \\
\hline S96T005936 & $177: 2$ & Lower half & 215.8 & 267 & $241.4^{Q C: 0}$ \\
\hline S96T005937 & $177: 3$ & Lower half & 292.7 & 272 & 282.35 \\
\hline S96T005938 & \multirow[t]{2}{*}{$177: 4$} & Upper half & 1,009 & 1,050 & $1,029.5$ \\
\hline S96T005939 & & Lower half & 1,385 & 1,510 & $1,447.5$ \\
\hline S96T005958 & \multirow[t]{2}{*}{$177: 5$} & Upper half & 2,304 & 2,200 & 2,252 \\
\hline S96T005959 & & Lower half & 3,017 & 2,880 & $2,948.5$ \\
\hline S96T005940 & 177: 6 & Lower half & 2,216 & 2,150 & 2,183 \\
\hline Minnus & & & Gyinilin & 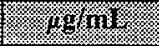 & . $199 \mathrm{~min}$ \\
\hline S96T005907 & $174: 5$ & Drainable liquid & 10,410 & 10,400 & 10,405 \\
\hline S96T005960 & $177: 5$ & Drainable liquid & 7,702 & 7,670 & 7,686 \\
\hline
\end{tabular}


Table B2-45. Tank 241-BY-112 Analytical Results: Fluoride (IC).

\begin{tabular}{|c|c|c|c|c|c|}
\hline Similor: & 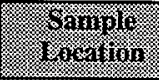 & S Sample & Resilil & Higineate & year \\
\hline \multicolumn{3}{|c|}{ 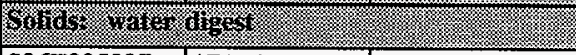 } & 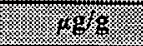 & 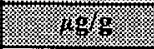 & 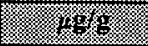 \\
\hline S96T005897 & 174: 1 & Lower half & 6,316 & 6,210 & 6,263 \\
\hline S96T005898 & $174: 2$ & Lower half & 7,358 & 6,960 & 7,159 \\
\hline S96T005899 & $174: 3$ & Lower half & 4,658 & 5,490 & 5,074 \\
\hline S96T005900 & $174: 4$ & Lower half & 2,652 & 6,390 & $4,521^{\mathrm{QC}: \mathrm{d}, \mathrm{o}}$ \\
\hline S96T005902 & \multirow[t]{2}{*}{$174: 5$} & Upper half & 4,707 & 3,610 & $4,158.5^{Q C: e}$ \\
\hline S96T005901 & & Lower half & 291.3 & 134 & $212.65^{Q \mathrm{C}: e}$ \\
\hline S96T005904 & \multirow[t]{2}{*}{$174: 6$} & \begin{tabular}{|l} 
Upper half \\
\end{tabular} & 9,042 & 10,600 & 9,821 \\
\hline S96T005903 & & Lower half & 55,800 & 54,600 & 55,200 \\
\hline S96T005935 & 177: 1 & Lower half & 12,340 & 12,300 & 12,320 \\
\hline S96T005936 & $177: 2$ & Lower half & 1,948 & 5,220 & $3,584^{Q \mathrm{C}: e}$ \\
\hline S96T005937 & $177: 3$ & Lower half & 6,378 & 6,700 & 6,539 \\
\hline S96T005938 & \multirow[t]{2}{*}{$177: 4$} & Upper half & 5,329 & 5,160 & $5,244.5$ \\
\hline S96T005939 & & Lower half & 6,935 & 7,940 & $7,437.5$ \\
\hline \$96T005958 & \multirow[t]{2}{*}{$177: 5$} & Upper half & 5,699 & 5,370 & $5,534.5$ \\
\hline S96T005959 & & Lower half & 2,882 & 2,800 & 2,841 \\
\hline S96T005940 & 177: 6 & Lower half & 15,960 & 15,600 & 15,780 \\
\hline Ginaris: & & & ogluris: & 18. & 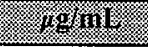 \\
\hline S96T005907 & $174: 5$ & Drainable liquid & 624 & 618 & 621 \\
\hline S96T005960 & $177: 5$ & Drainable liquid & 809.8 & 724 & 766.9 \\
\hline
\end{tabular}




\begin{tabular}{|c|c|c|c|c|c|}
\hline$S 0+Z \angle 60^{\circ} z$ & $\mathrm{SO}+30 \angle 0^{\circ} \mathrm{Z}$ & $s 0+\exists \rightarrow Z I^{*} Z$ & p!̣b! әฺqеu!eıa & $s: L L I$ & 096S00I96S \\
\hline SO+BIIL'I & $\mathrm{SO}+300 L^{\circ} \mathrm{I}$ & $S O+G Z Z L^{\circ} \mathrm{I}$ & 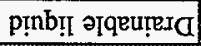 & $\varsigma: \forall \angle I$ & L06S00L96S \\
\hline (1\% & 69ing & 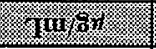 & & & (8) \\
\hline$\therefore: 00 \angle 9^{4} I L$ & $009^{\circ} 95$ & $0 \nabla L ' 98$ & J[Еप Іәмо I & $9: L L \mathrm{I}$ & $0+6500 \mathrm{~L} 96 \mathrm{~S}$ \\
\hline 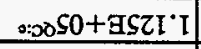 & $\mathrm{S} 0+\mathrm{B} 08 \mathrm{Z} \cdot \mathrm{I}$ & $0 \varepsilon 0^{\circ} \angle 6$ & JГеप IәMOT & \multirow[b]{2}{*}{$s: L L T$} & 6S6S00L96S \\
\hline $06 I^{\prime} \mathrm{s} 8$ & $000^{\circ} \mathcal{E} 8$ & $08 \varepsilon^{6} \angle 8$ & IIRप Iədd $\cap$ & & 8S6S00L96S \\
\hline $2: 0000 \mathcal{E}^{\prime} \$ 6$ & $006^{\prime} 18$ & $\mathrm{SO}+\mathrm{B} \angle 80^{\circ} \mathrm{I}$ & IГЕप IәMOT & \multirow[b]{2}{*}{$\downarrow: L L T$} & 6E6S00I96S \\
\hline SLI'I9 & $00 I^{\prime} \$ 9$ & $0 S Z^{6} \angle S$ & J[Eप I2dd & & $8 E 6500 \mathrm{~L} 96 \mathrm{~S}$ \\
\hline $0: 00 \$ 6 L^{\prime} \subseteq \varepsilon$ & $009^{\circ} \angle D$ & $066^{\circ} \varepsilon Z$ & J[Еप IәMOT] & $\varepsilon: L L \mathrm{I}$ & LE6S00LL6S \\
\hline 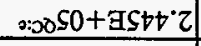 & $00 L^{\prime} z Z$ & $90+\exists \varepsilon 99^{\circ} \nabla$ & J[Еप Iәмот] & $\tau: \angle L I$ & $9 \varepsilon 6500 \mathrm{~L} 96 \mathrm{~S}$ \\
\hline$S Z \varepsilon^{6}+I$ & $00 \varepsilon^{\prime} \nabla I$ & $0 S E^{\prime} \nabla I$ & f[Еप دәмоТ] & $I: L L I$ & SE6S00L96S \\
\hline $508^{4} 89$ & $000^{6} 69$ & 019689 & IГएप Iәмот & \multirow[b]{2}{*}{$9: \forall<I$} & E06S00J96S \\
\hline $09 S^{\prime} 8 L$ & $00 L^{6} \mathcal{E} 8$ & $0 Z \nabla^{6} \varepsilon L$ & J[Rप Iədd $\Omega$ & & t06S00L96S \\
\hline :00869' $\mathrm{s}$ & $090^{\circ} \mathcal{E}$ & $9 \varepsilon \varepsilon^{\prime} 8$ & I[Еप IЭMOT & \multirow[b]{2}{*}{$s: \nabla L I$} & I06S00L96S \\
\hline $0 Ð L ' 8 L$ & $00 t^{\prime} \mathcal{E} L$ & $080^{\circ}+8$ & કाеप Iədd $\Omega$ & & $206500 \mathrm{~L} 96 \mathrm{~S}$ \\
\hline$\Delta: p: \infty S O+\exists \forall \angle Z^{*} I$ & $50+30 \angle 8^{\circ} \mathrm{I}$ & $018^{\circ} \angle 9$ & J[Eप دәмоT] & $t: t<\mathrm{I}$ & 006S00I96S \\
\hline $009^{\prime} \mathrm{sz}$ & $00 L^{6} \nabla z$ & $00 s^{\prime} 9 z$ & 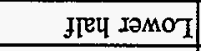 & $\varepsilon: t L I$ & 668S00L96S \\
\hline $0 S E^{\prime} 8 S$ & $000^{\prime} \varepsilon 9$ & $00 L^{\prime} \varepsilon S$ & JाЕप Iәмот & $\tau: \nabla L I$ & $868 \mathrm{S00L96S}$ \\
\hline$: 0 x 0+9^{\circ} 0 \mathrm{I}$ & $06 t^{\prime} 6$ & $06 L^{6}$ II I & I[Еप Іәмот] & $I: t L I$ & L68S00.L96S \\
\hline 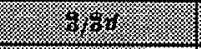 & (3) & (6in & & \multicolumn{2}{|c|}{ H. } \\
\hline 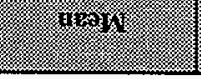 & 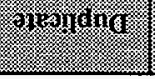 & minged & 3010\% & 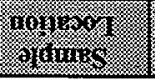 & 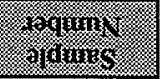 \\
\hline
\end{tabular}

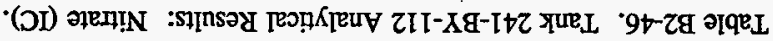


HNF-SD-WM-ER-701 Rev. 0

Table B2-47. Tank 241-BY-112 Analytical Results: Nitrite (IC).

\begin{tabular}{|c|c|c|c|c|c|}
\hline 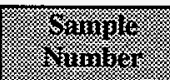 & Sorminifir & $\begin{array}{l}\text { Samples } \\
\text { porfon }\end{array}$ & Pesill & Birilicule & - 191 \\
\hline \multicolumn{3}{|c|}{ 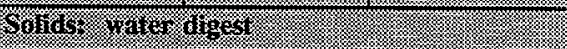 } & 1089 & 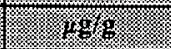 & 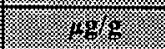 \\
\hline S96T005897 & 174: 1 & Lower half & 5,285 & 4,260 & $4,772.5^{\mathrm{ec}: \mathrm{e}}$ \\
\hline S96T005898 & $174: 2$ & Lower half & 3,108 & 3,100 & 3,104 \\
\hline S96T005899 & $174: 3$ & Lower half & 4,068 & 5,170 & $4,619^{\mathrm{QC}: 0}$ \\
\hline S96T005900 & $174: 4$ & Lower half & 14,300 & 20,400 & $17,350^{\varrho \mathrm{QC:d,e}}$ \\
\hline S96T005902 & \multirow[t]{2}{*}{$174: 5$} & Upper half & 39,770 & 40,800 & 40,285 \\
\hline S96T005901 & & Lower half & 944 & 2,160 & $1,552^{\mathrm{QC}: \mathrm{e}}$ \\
\hline S96T005904 & \multirow[t]{2}{*}{$174: 6$} & Upper half & 57,720 & 65,400 & 61,560 \\
\hline S96T005903 & & Lower half & 56,540 & 55,200 & 55,870 \\
\hline S96T005935 & 177: 1 & Lower half & 5,474 & 5,530 & 5,502 \\
\hline S96T005936 & $177: 2$ & Lower half & 2,858 & 4,030 & $3,444^{\mathrm{QC}: \mathrm{e}}$ \\
\hline S96T005937 & $177: 3$ & Lower half & 4,498 & 4,340 & 4,419 \\
\hline S96T005938 & \multirow[t]{2}{*}{$177: 4$} & Upper half & 18,610 & 19,200 & 18,905 \\
\hline S96T005939 & & Lower half & 25,470 & 27,600 & 26,535 \\
\hline S96T005958 & \multirow[t]{2}{*}{$177: 5$} & Upper half & 42,020 & 40,500 & 41,260 \\
\hline S96T005959 & & Lower half & 54,900 & 50,800 & 52,850 \\
\hline S96T005940 & $177: 6$ & Lower half & 31,840 & 37,500 & 34,670 \\
\hline (Wornde & & & 109mil & 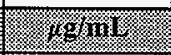 & (1) \\
\hline S96T005907 & $174: 5$ & Drainable liquid & $1.311 \mathrm{E}+05$ & $1.310 \mathrm{E}+05$ & $1.311 \mathrm{E}+05$ \\
\hline S96T005960 & $177: 5$ & Drainable liquid & $1.503 E+05$ & $1.480 \mathrm{E}+05$ & $1.492 \mathrm{E}+05$ \\
\hline
\end{tabular}


Table B2-48. Tank 241-BY-112 Analytical Results: Phosphate (IC).

\begin{tabular}{|c|c|c|c|c|c|}
\hline Suminicer & 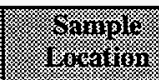 & $\begin{array}{l}\text { Samingle } \\
\text { Porition }\end{array}$ & Resinti & Buplicare & Meall \\
\hline \multicolumn{3}{|c|}{ 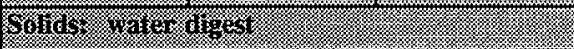 } & 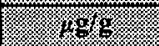 & 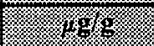 & $8 y^{2}$ \\
\hline S96T005897 & 174: 1 & Lower half & 37,810 & 39,100 & 38,455 \\
\hline S96T005898 & $174: 2$ & Lower half & 4,869 & 9,780 & $7,324.5^{\text {QC:d,eo }}$ \\
\hline S96T005899 & $174: 3$ & Lower half & 1,843 & 953 & $1,398^{\mathrm{QC:e}}$ \\
\hline S96T005900 & $174: 4$ & Lower half & 2,760 & 4,040 & $3,400^{\text {QC:e }}$ \\
\hline S96T005902 & \multirow[t]{2}{*}{$174: 5$} & Upper half & 9,975 & 2,750 & $6,362.5^{\mathrm{QC:e}}$ \\
\hline S96T005901 & & Lower half & 221.1 & 388 & $304.55^{\mathrm{QC}: e}$ \\
\hline S96T005904 & \multirow[t]{2}{*}{$174: 6$} & Upper half & 9,679 & 11,200 & $10,439.5$ \\
\hline S96T005903 & & Lower half & $<2,494$ & $<2,430$ & $<2,462$ \\
\hline S96T005935 & $177: 1$ & Lower half & $1.063 \mathrm{E}+05$ & $1.060 \mathrm{E}+05$ & $1.062 \mathrm{E}+05$ \\
\hline S96T005936 & $177: 2$ & Lower half & 6,453 & 18,100 & $12,276.5^{\mathrm{QC:O}}$ \\
\hline S96T005937 & $177: 3$ & Lower half & 2,191 & 7,700 & $4,945.5^{\mathrm{CC:e}}$ \\
\hline S96T005938 & \multirow[t]{2}{*}{$177: 4$} & Upper half & 2,766 & 2,360 & 2,563 \\
\hline S96T005939 & & Lower half & 3,905 & 35,000 & $19,452.5^{\infty \mathrm{C}: \mathrm{e}}$ \\
\hline S96T005958 & \multirow[t]{2}{*}{$177: 5$} & Upper half & 3,462 & 5,030 & $4,246^{\alpha: e}$ \\
\hline S96T005959 & & Lower half & 3,269 & 2,580 & $2,924.5^{\mathrm{QC}: \mathrm{e}}$ \\
\hline S96T005940 & $177: 6$ & Lower half & 2,507 & 1,860 & $2,183.5^{\text {QC:c }}$ \\
\hline Wignidu: & & & . $1496 \mathrm{mII}$ & (19.6) & 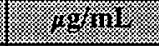 \\
\hline S96T005907 & $174: 5$ & Drainable liquid & $<1,224$ & 1,810 & $<1,517^{\mathrm{QC}: \mathrm{c}}$ \\
\hline S96T005960 & $177: 5$ & Drainable liquid & 1,479 & 1,410 & $1,444.5$ \\
\hline
\end{tabular}


Table B2-49. Tank 241-BY-112 Analytical Results: Sulfate (IC).

\begin{tabular}{|c|c|c|c|c|c|}
\hline Sininitist & Stration & Sampil & nesint & ompincate & Vman: \\
\hline \multicolumn{3}{|c|}{ 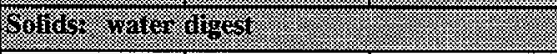 } & 1.98. & 168 & I) \\
\hline S96T005897 & 174: 1 & Lower half & 3,953 & 2,620 & $3,286.5^{\text {CC:e }}$ \\
\hline S96T005898 & $174: 2$ & Lower half & 17,580 & 17,300 & 17,440 \\
\hline S96T005899 & $174: 3$ & Lower half & 17,470 & 20,700 & 19,085 \\
\hline S96T005900 & 174: 4 & Lower half & 19,500 & 28,300 & $23,900^{\mathrm{QC}: \mathrm{d}, \mathrm{e}}$ \\
\hline S96T005902 & \multirow[t]{2}{*}{$174: 5$} & Upper half & 18,890 & 17,100 & 17,995 \\
\hline S96T005901 & & Lower half & 1,279 & 540 & $909.5^{\text {QC:e }}$ \\
\hline S96T005904 & \multirow[t]{2}{*}{$174: 6$} & Upper half & 36,910 & 42,400 & 39,655 \\
\hline S96T005903 & & Lower half & $1.263 \mathrm{E}+05$ & $1.240 \mathrm{E}+05$ & $1.252 \mathrm{E}+05$ \\
\hline S96T005935 & 177: 1 & Lower half & 5,194 & 5,230 & 5,212 \\
\hline S96T005936 & $177: 2$ & Lower half & 3,944 & 9,450 & $6,697^{\mathrm{Qc:c}}$ \\
\hline S96T005937 & $177: 3$ & Lower half & 8,076 & 7,570 & 7,823 \\
\hline S96T005938 & \multirow[t]{2}{*}{ 177: 4} & Upper half & 20,270 & 19,200 & 19,735 \\
\hline S96T005939 & & Lower half & 26,000 & 30,700 & 28,350 \\
\hline S96T005958 & \multirow[t]{2}{*}{$177: 5$} & Upper half & 16,700 & 15,800 & 16,250 \\
\hline S96T005959 & & Lower half & 11,410 & 13,200 & 12,305 \\
\hline S96T005940 & $177: 6$ & Lower half & 71,790 & 67,500 & 69,645 \\
\hline Writis: & & (3:- & (1) & (1) & 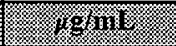 \\
\hline S96T005907 & $174: 5$ & Drainable liquid & 2,702 & 2,920 & 2,811 \\
\hline S96T005960 & $177: 5$ & Drainable liquid & $<710.8$ & 17,400 & $<9,055.4^{\mathrm{QC:e}}$ \\
\hline
\end{tabular}


Table B2-50. Tank 241-BY-112 Analytical Results: Oxalate (IC).

\begin{tabular}{|c|c|c|c|c|c|}
\hline 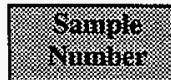 & 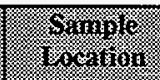 & Sravere & 28csuit & Duppinati: & 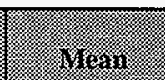 \\
\hline \multicolumn{3}{|c|}{ 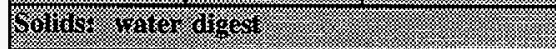 } & 1696 & 1098 & $f_{1}$ \\
\hline S96T005897 & $174: 1$ & Lower half & 8,564 & 3,040 & $5,802^{\alpha c: e}$ \\
\hline S96T005898 & 174: 2 & Lower half & 486.2 & 486 & 486.1 \\
\hline S96T005899 & 174: 3 & Lower half & 4,112 & 11,600 & $7,856^{\text {QC:e }}$ \\
\hline S96T005900 & $174: 4$ & Lower half & 30,210 & $1.050 \mathrm{E}+05$ & $67,605^{\propto C: d, \vartheta}$ \\
\hline S96T005902 & \multirow[t]{2}{*}{$174: 5$} & Upper half & 49,830 & 50,200 & 50,015 \\
\hline S96T005901 & & Lower half & 4,706 & 1,100 & $2,903^{\mathrm{OC}: \mathrm{e}}$ \\
\hline S96T005904 & \multirow[t]{2}{*}{$174: 6$} & Upper half & 22,950 & 23,500 & 23,225 \\
\hline S96T005903 & & Lower half & 2,452 & 1,270 & $1,861^{\mathrm{QC}: \mathrm{c}, \mathrm{e}}$ \\
\hline S96T005935 & 177: 1 & Lower half & 2,744 & 2,690 & 2,717 \\
\hline S96T005936 & $177: 2$ & Lower half & 1,304 & 5,970 & $3,637^{\mathrm{QC:c}}$ \\
\hline S96T005937 & $177: 3$ & Lower half & $<882.9$ & $<800$ & $<841.45$ \\
\hline S96T005938 & \multirow[t]{2}{*}{$177: 4$} & Upper half & 41,050 & 35,900 & $38,475^{Q C: c}$ \\
\hline S96T005939 & & Lower half & $1.110 \mathrm{E}+05$ & $1.300 \mathrm{E}+05$ & $1.205 \mathrm{E}+05$ \\
\hline S96T005958 & \multirow[t]{2}{*}{$177: 5$} & Upper half & $1.185 \mathrm{E}+05$ & $1.160 \mathrm{E}+05$ & $1.173 \mathrm{E}+05$ \\
\hline S96T005959 & & Lower half & 34,560 & 37,300 & 35,930 \\
\hline S96T005940 & $177: 6$ & Lower half & 6,203 & 15,500 & $10,851.5^{\mathrm{QC}: e}$ \\
\hline Fryulas & & & f & 1: & 196ring \\
\hline S96T005907 & $174: 5$ & Drainable liquid & $<1,071$ & 10,600 & $<5,835.5^{\mathrm{QC}: \mathrm{C}}$ \\
\hline S96T005960 & $177: 5$ & Drainable liquid & 840.3 & 750 & 795.15 \\
\hline
\end{tabular}


Table B2-51. Tank 241-BY-112 Analytical Results: Bulk Density.

\begin{tabular}{|c|c|c|c|c|c|c|}
\hline 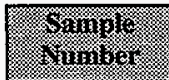 & Shmole & P Pon & Iresint & Mapiliante & Tripliester & Mrean \\
\hline Sivitas : & 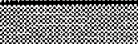 & স) & ginil & $86 x^{2}$ & - 8 inII & 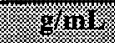 \\
\hline S96T005865 & 174: 1 & Lower half & 1.03 & $n / a$ & $\mathrm{n} / \mathrm{a}$ & 1.03 \\
\hline S96T005866 & 174: 2 & Lower half & 1.1 & $n / a$ & $n / a$ & 1.1 \\
\hline S96T005867 & 174: 3 & Lower half & 1.08 & $n / a$ & $n / a$ & 1.08 \\
\hline S96T005868 & 174: 4 & Lower half & 1.86 & $\mathrm{n} / \mathrm{a}$ & $n / a$ & 1.86 \\
\hline S96T005869 & $174: 5$ & Lower half & 1.66 & $n / a$ & $\mathrm{n} / \mathrm{a}$ & 1.66 \\
\hline S96T005871 & 174: 6 & Lower half & 1.82 & $\mathrm{n} / \mathrm{a}$ & $n / a$ & 1.82 \\
\hline S96T005912 & 177: 2 & Lower half & 1.19 & $n / a$ & $n / a$ & 1.19 \\
\hline S96T005913 & $177: 3$ & Lower half & 1.07 & $n / a$ & $n / a$ & 1.07 \\
\hline S96T005915 & $177: 4$ & Lower half & 1.78 & $n / a$ & $n / a$ & 1.78 \\
\hline S96T005942 & $177: 5$ & Lower half & 1.56 & $n / a$ & $n / a$ & 1.56 \\
\hline S96T005916 & $177: 6$ & Lower half & 1.86 & $\mathrm{n} / \mathrm{a}$ & $n / a$ & 1.86 \\
\hline
\end{tabular}


Table B2-52. Tank 241-BY-112 Analytical Results: Exotherm - Transition 1 Wet (DSC).

\begin{tabular}{|c|c|c|c|c|c|}
\hline Sarnyle & Samplo & S Pontivis & - Rersil & 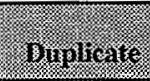 & 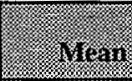 \\
\hline Mnuids : & স্য & : : & $\sqrt{19 g}$ & $1 / 9$. & ? \\
\hline S96T005907 & $174: 5$ & Drainable liquid & 99.19 & 80.44 & $89.815^{\mathrm{QC:}: \theta}$ \\
\hline S96T005960 & $177: 5$ & Drainable liquid & 72.64 & 36.61 & $54.625^{\text {QC.e }}$ \\
\hline Solow & r) & - & 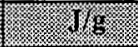 & (1) & ) \\
\hline S96T005876 & 174: 4 & Lower half & 134.5 & 128.6 & 131.55 \\
\hline S96T005878 & $174: 5$ & Upper half & 118.1 & 233.4 & $175.75^{\mathrm{QC}: \mathrm{c}}$ \\
\hline S96T005877 & & Lower half & 61.3 & 63.7 & 62.5 \\
\hline S96T005880 & $174: 6$ & Upper half & 67.9 & 139 & $103.45^{\mathrm{QC}: \mathrm{c}}$ \\
\hline S96T005879 & & Lower half & 5.06 & 22.7 & $13.88^{\mathrm{QC:e}}$ \\
\hline S96T005919 & $177: 3$ & Lower half & 76.4 & 136 & $106.2^{\mathrm{QC:c}}$ \\
\hline S96T005920 & $177: 4$ & Upper half & 117 & 66.9 & $91.95^{\mathrm{Cc:e}}$ \\
\hline S96T005921 & & Lower half & 149.9 & 127.9 & 138.9 \\
\hline S96T005950 & $177: 5$ & Upper half & 50.9 & 142 & $96.45^{\mathrm{QC:}: \mathrm{e}}$ \\
\hline S96T005951 & & Lower half & 99.2 & 111 & 105.1 \\
\hline S96T005922 & $177: 6$ & Lower half & 50.8 & 58.3 & $\overline{54.55}$ \\
\hline
\end{tabular}


Table B2-53. Tank 241-BY-112 Analytical Results: Percent Water (TGA).

\begin{tabular}{|c|c|c|c|c|c|}
\hline Thingus & S & Pample & Resill: & ourinieate & 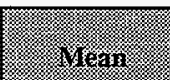 \\
\hline SWhas & & (3) & W" & 1: & 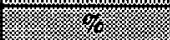 \\
\hline S96T005873 & 174: 1 & Lower half & 22.29 & 25.14 & 23.715 \\
\hline S96T005874 & 174: 2 & Lower half & 14.42 & 14.39 & 14.405 \\
\hline S96T005875 & $174: 3$ & Lower half & 13.69 & 15.65 & 14.67 \\
\hline S96T005876 & 174: 4 & Lower half & 23.17 & 23.4 & 23.285 \\
\hline S96T005878 & \multirow[t]{2}{*}{$174: 5$} & Upper half & 33.78 & 34.17 & 33.975 \\
\hline S96T005877 & & Lower half & 43.53 & 41.79 & 42.66 \\
\hline S96T005880 & \multirow[t]{2}{*}{$174: 6$} & Upper half & 37.56 & 36.86 & 37.21 \\
\hline S96T005879 & & Lower half & 32.89 & 33.03 & 32.96 \\
\hline S96T005917 & \multirow[t]{2}{*}{$177: 1$} & Lower half & 43.02 & 39.42 & 41.22 \\
\hline S96T005917 & & Lower half & 39.43 & 21.83 & $30.63^{\mathrm{Qc}: e}$ \\
\hline S96T005918 & $177: 2$ & Lower half & 15.73 & 15 & 15.365 \\
\hline S96T005919 & $177: 3$ & Lower half & 21.15 & 15.94 & 18.545 \\
\hline S96T005920 & \multirow[t]{2}{*}{$177: 4$} & Upper half & 18.25 & 21.46 & 19.855 \\
\hline S96T005921 & & Lower half & 36.42 & 36.86 & 36.64 \\
\hline S96T005950 & \multirow[t]{2}{*}{$177: 5$} & Upper half & 32.32 & 34.77 & 33.545 \\
\hline S96T005951 & & Lower half & 40.34 & 40.06 & 40.2 \\
\hline S96T005922 & $177: 6$ & Lower half & 29.71 & 27.66 & 28.685 \\
\hline Eiguiris & & & 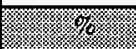 & . & (1) \\
\hline S96T005907 & $174: 5$ & Drainable liquid & 48.69 & 48.06 & 48.375 \\
\hline S96T005960 & $177: 5$ & Drainable liquid & 48.75 & 48.6 & 48.675 \\
\hline
\end{tabular}


Table B2-54. Tank 241-BY-112 Analytical Results: Specific Gravity.

\begin{tabular}{|c|c|c|c|c|c|}
\hline Sinnis & S4minin & $\begin{array}{l}\text { Sannole } \\
\text { Domition }\end{array}$ & resim & Bulpulatic & 818 \\
\hline 4rimis & 4 & (3) & miniles & Inniless & umithess \\
\hline S96T005907 & $174: 5$ & Drainable liquid & 1.474 & 1.478 & 1.476 \\
\hline S96T005960 & $177: 5$ & Drainable liquid & 1.462 & 1.47 & 1.466 \\
\hline
\end{tabular}

Table B2-55. Tank 241-BY-112 Analytical Results: Total Alpha (Alpha).

\begin{tabular}{|c|c|c|c|c|c|}
\hline Sumple & $\begin{array}{l}\text { Sompinte } \\
\text { Sogation }\end{array}$ & Sanine & nesuin & Briplinere & mean: \\
\hline 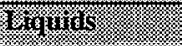 & (3) & 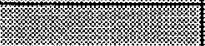 & $10 \% 1 \mathrm{ml}$ & 80.11mi & 1. \\
\hline S96T005907 & $174: 5$ & Drainable liquid & $<0.0122$ & $<0.0122$ & $<0.0122$ \\
\hline S96T005960 & 177: 5 & Drainable liquid & $<0.00611$ & $<0.0346$ & $<0.020355^{\mathrm{QC}: \mathrm{e}}$ \\
\hline 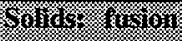 & & & 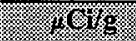 & 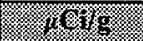 & - Ex \\
\hline S96T005889 & 174: 1 & Lower half & 0.115 & 0.0874 & $0.1012^{\mathrm{QC:c}}$ \\
\hline \$96T005890 & $174: 2$ & Lower half & 0.0326 & 0.0275 & 0.03005 \\
\hline S96T005891 & $174: 3$ & Lower half & 0.0373 & 0.0657 & $0.0515^{Q C: c}$ \\
\hline S96T005892 & 174: 4 & Lower half & 0.236 & 0.279 & 0.2575 \\
\hline S96T005893 & $174: 5$ & Lower half & 0.0665 & 0.0433 & $0.0549^{\mathrm{QC}: e}$ \\
\hline S96T005895 & 174: 6 & Lower half & 0.0618 & 0.0628 & $0.0623^{\mathrm{QC:c}, \mathrm{f}}$ \\
\hline S96T005929 & 177: 1 & Lower half & 0.00232 & 0.00232 & 0.00232 \\
\hline S96T005930 & $177: 2$ & Lower half & 0.0402 & 0.0355 & 0.03785 \\
\hline S96T005931 & $177: 3$ & Lower half & 0.0497 & 0.0475 & 0.0486 \\
\hline S96T005933 & $177: 4$. & Lower half & 0.174 & 0.154 & 0.164 \\
\hline S96T005957 & $177: 5$ & Lower half & 0.045 & 0.0459 & $0.04545^{\mathrm{QCf} f}$ \\
\hline S96T005934 & $177: 6$ & Lower half & 0.0399 & 0.039 & $0.03945^{\mathrm{QC:f}}$ \\
\hline
\end{tabular}


Table B2-56. Tank 241-BY-112 Analytical Results: Total Inorganic Carbon.

\begin{tabular}{|c|c|c|c|c|c|c|}
\hline 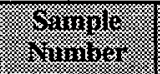 & 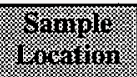 & Samile & mesulit & Dimitinate & I Hivinaren & 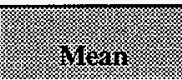 \\
\hline Soling & 4 & 4 & 146.8 & $14 \% 15$ & 1048 & isels: \\
\hline S96T005873 & 174: 1 & Lower half & 47,400 & 44,400 & & 45,900 \\
\hline S96T005874 & 174: 2 & Lower half & 85,200 & 82,600 & & 83,900 \\
\hline S96T005875 & $174: 3$ & Lower half & 79,700 & 82,000 & & 80,850 \\
\hline S96T005876 & $174: 4$ & Lower half & 17,200 & 12,800 & 13,300 & $14,433.3^{\alpha_{c: c, c}}$ \\
\hline S96T005878 & $174: 5$ & Upper half & 22,900 & 25,600 & & 24,250 \\
\hline S96T005877 & & Lower half & 26,800 & 17,900 & 27,100 & $23,933.3^{\mathrm{QC:c}}$ \\
\hline S96T005880 & $174: 6$ & Upper half & 20,200 & 11,800 & 10,600 & $14,200^{\mathrm{QC:}}$ \\
\hline S96T005879 & & Lower half & 727 & 720 & & 723.5 \\
\hline S96T005917 & $177: 1$ & Lower half & 34,300 & 36,000 & & 35,150 \\
\hline S96T005918 & $177: 2$ & Lower half & 78,400 & 81,900 & & 80,150 \\
\hline S96T005919 & $177: 3$ & Lower half & 68,500 & 79,200 & & 73,850 \\
\hline S96T005920 & $177: 4$ & Upper half & 49,800 & 56,200 & & $53,000^{\mathrm{eC:d}}$ \\
\hline S96T005921 & & Lower half & 11,900 & 6,740 & & $9,320^{\alpha c: c}$ \\
\hline S96T005950 & $177: 5$ & Upper half & 13,100 & 11,000 & & 12,050 \\
\hline S96T005951 & & Lower half & 12,700 & 10,400 & & 11,550 \\
\hline S96T005922 & $177: 6$ & Lower half & 11,600 & 17,400 & & $14,500^{\mathrm{QC}: \mathrm{e}}$ \\
\hline Uinuinis: & 28 & 6 & 16. & $199 \ln 11$ & (6) & 196/2n: \\
\hline S96T005907 & $174: 5$ & $\begin{array}{l}\text { Drainable } \\
\text { liquid }\end{array}$ & 1,590 & 1,650 & & $1,620^{\circ \mathrm{C}: f}$ \\
\hline S96T005960 & $177: 5$ & \begin{tabular}{|l|} 
Drainable \\
liquid
\end{tabular} & 1,470 & 1,460 & & $1,465^{\text {QC:f }}$ \\
\hline
\end{tabular}


Table B2-57. Tank 241-BY-112 Analytical Results: Total Organic Carbon (Wet).

\begin{tabular}{|c|c|c|c|c|c|c|}
\hline 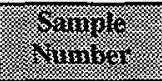 & S & 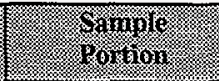 & Resilit & Buiningre & 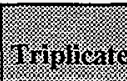 & Vivent \\
\hline Solving & 4. & 4 & 1.969 & 1.289 & 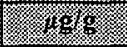 & (3) \\
\hline S96T005873 & 174: 1 & Lower half & 1,140 & 1,230 & & 1,185 \\
\hline S96T005874 & 174: 2 & Lower half & 378 & 698 & & $538^{\mathrm{QC:e}}$ \\
\hline$\$ 96 \mathrm{~T} 005875$ & $174: 3$ & Lower half & 913 & 1,280 & & $1,096.5^{\mathrm{QC}: \mathrm{o}}$ \\
\hline S96T005876 & 174: 4 & Lower half & 30,700 & 34,300 & & $32,500^{\circ \mathrm{C}: \mathrm{c}}$ \\
\hline S96T005878 & $174: 5$ & Upper half & 14,200 & 14,100 & & 14,150 \\
\hline S96T005877 & & Lower half & 6,160 & 7,710 & 5,360 & $6,410^{\mathrm{QC}: c, \mathrm{c}}$ \\
\hline S96T005880 & $174: 6$ & Upper half & 6,640 & 7,990 & 7,700 & $7,443.33$ \\
\hline S96T005879 & & Lower half & 1,550 & 1,560 & & 1,555 \\
\hline S96T005917 & $177: 1$ & Lower half & 1,390 & 1,260 & & 1,325 \\
\hline S96T005918 & $177: 2$ & Lower half & 904 & 750 & & 827 \\
\hline S96T005919 & $177: 3$ & Lower half & 516 & 555 & & 535.5 \\
\hline S96T005920 & $177: 4$ & Upper half & 7,330 & 6,080 & & 6,705 \\
\hline S96T005921 & & Lower half & 29,800 & 25,300 & & 27,550 \\
\hline S96T005950 & $177: 5$ & Upper half & 23,400 & 17,800 & & $20,600^{\mathrm{QC}: \theta}$ \\
\hline S96T005951 & & Lower half & 8,450 & 8,780 & & 8,615 \\
\hline S96T005922 & $177: 6$ & Lower half & 4,740 & 4,630 & & 4,685 \\
\hline 1Mryulis & 4 & (2) & 1. & (19.9) & ingming & (1.5. \\
\hline S96T005907 & $174: 5$ & Drainable liquid & 1,890 & 1,940 & & $1,915^{\text {eC:f }}$ \\
\hline S96T005960 & $177: 5$ & Drainable liquid & 1,510 & 1,530 & & $1,520^{\mathrm{QC}: \mathrm{f}}$ \\
\hline
\end{tabular}




\section{B2.2 VAPOR PHASE MEASUREMENTS}

\section{B2.2.1 Safety Screening and Flammable Gas Monitoring}

Before the October 2 push mode core sampling of tank 241-BY-112, a vapor phase measurement was taken. Additional measurements were made on October 7, 1996. These measurements supported the safety screening DQO (Dukelow et al. 1995). The vapor phase screening was taken for flammability issues. The vapor phase measurements were taken $20 \mathrm{ft}$ below risers 18 and 21 in the headspace of the tank, and results were obtained in the field (that is, no gas sample was sent to the laboratory for analysis). Table B2-58 shows the results of the vapor phase measurements.

\section{B2.2.2 1994 Tank Vapor Samples}

Headspace and vapor samples were collected from tank 241-BY-112 using the vapor sampling system on November 18, 1994, by the Westinghouse Hanford Company Sampling and Mobile Laboratories. Sample collection and analysis were performed as directed by the tank 241-BY-112 tank characterization plan (Homi 1994). The results of the headspace gas and vapor characterization are reported in Huckaby and Bratzel (1995). Table B2-59 summarizes the results of these analyses. 
Table B2-58. Results of Vapor Measurements of Tank 241-BY-112.

\begin{tabular}{|c|c|c|}
\hline \multirow{2}{*}{ (4) } & \multicolumn{2}{|c|}{ 1. Ressilt } \\
\hline & $(06$ tober $2,19 \% 6$ & 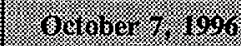 \\
\hline Total organic carbon (TOC) & $12 \mathrm{ppmv}$ & $4.2 \mathrm{ppmv}$ \\
\hline Lower explosive limit (LEL) & $1.0 \%$ of $\mathrm{LEL}$ & $0.0 \%$ of LEL \\
\hline Oxygen & $18.5 \%$ & $20.8 \%$ \\
\hline Ammonia & $80 \mathrm{ppmv}$ & 50.ppmv \\
\hline
\end{tabular}

Table B2-59. Result of Vapor Analysis in Headspace of Tank 241-BY-112.

\begin{tabular}{|c|c|}
\hline 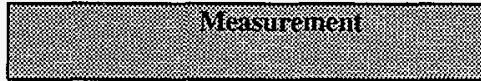 & 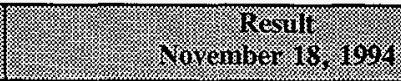 \\
\hline Headspace temperature $\left({ }^{\circ} \mathrm{C}\right)$ & 23.2 \\
\hline Ammonia (ppmv) & 63 \\
\hline Hydrogen (ppmv) & $<94$ \\
\hline Carbon dioxide (ppmv) & 121 \\
\hline Carbon monoxide (ppmv) & $<12$ \\
\hline Nitric oxide (ppmv) & 0.18 \\
\hline Nitrogen dioxide (ppmv) & $\leq 0.02$ \\
\hline Nitrous oxide (ppmv) & 40 \\
\hline Water vapor $\left(\mathrm{mg} / \mathrm{m}^{3}\right)$ & 11.2 \\
\hline Water vapor (percent relative humidity) & 53 \\
\hline Ethanenitrile (ppmv) & 0.10 \\
\hline Propanone (acetone) (ppmv) & 1.0 \\
\hline 1-Butanol (ppmv) & 0.059 \\
\hline n-Dodecane (ppmv) & 0.0097 \\
\hline n-Tridecane (ppmv) & 0.020 \\
\hline Total organic compounds $\left(\mathrm{mg} / \mathrm{m}^{3}\right)$ & 5.8 \\
\hline
\end{tabular}




\section{B2.3 HISTORICAL SAMPLE RESULTS}

\section{B2.3.1 January 1972 Sample Results}

Table B2-60 shows the results of the analyses of the January 1972 sampling event for tank 241-BY-112 that are documented in Buckingham (1972). The results indicate the waste contains primarily sodium salts; the solids primarily sodium nitrate. The results also indicated a higher concentration of chromium than expected. As a result, a further review was to be conducted to determine the reason for this anomaly. The radionuclides found in the sample were strontium, cesium, and zirconium/niobium in the liquid and top solids. Antimony, ruthenium/rhodium, and cerium/praseodymium were also found in the bottom sample. These data have not been validated and should be used with caution.

\section{B2.3.2 April 1971 Sample Results}

Table B2-61 shows the results of analyses of the April 1971 sampling event for tank 241-BY-112 that were documented in Buckingham (1971). The results indicate the waste contains primarily sodium salts of nitrate and nitrite. The results were very similar to January 1972 results. The radionuclides found in the sample were strontium and cesium in the supernatant sample; the sludge sample also contained ruthenium/rhodium, cobalt, antimony, and cerium/praseodymium; and the crust sample including zirconium/niobium and europium. These data have not been validated and should be used with caution. 
Table B2-60. Tank 241-BY-112 Sample. ${ }^{1}$

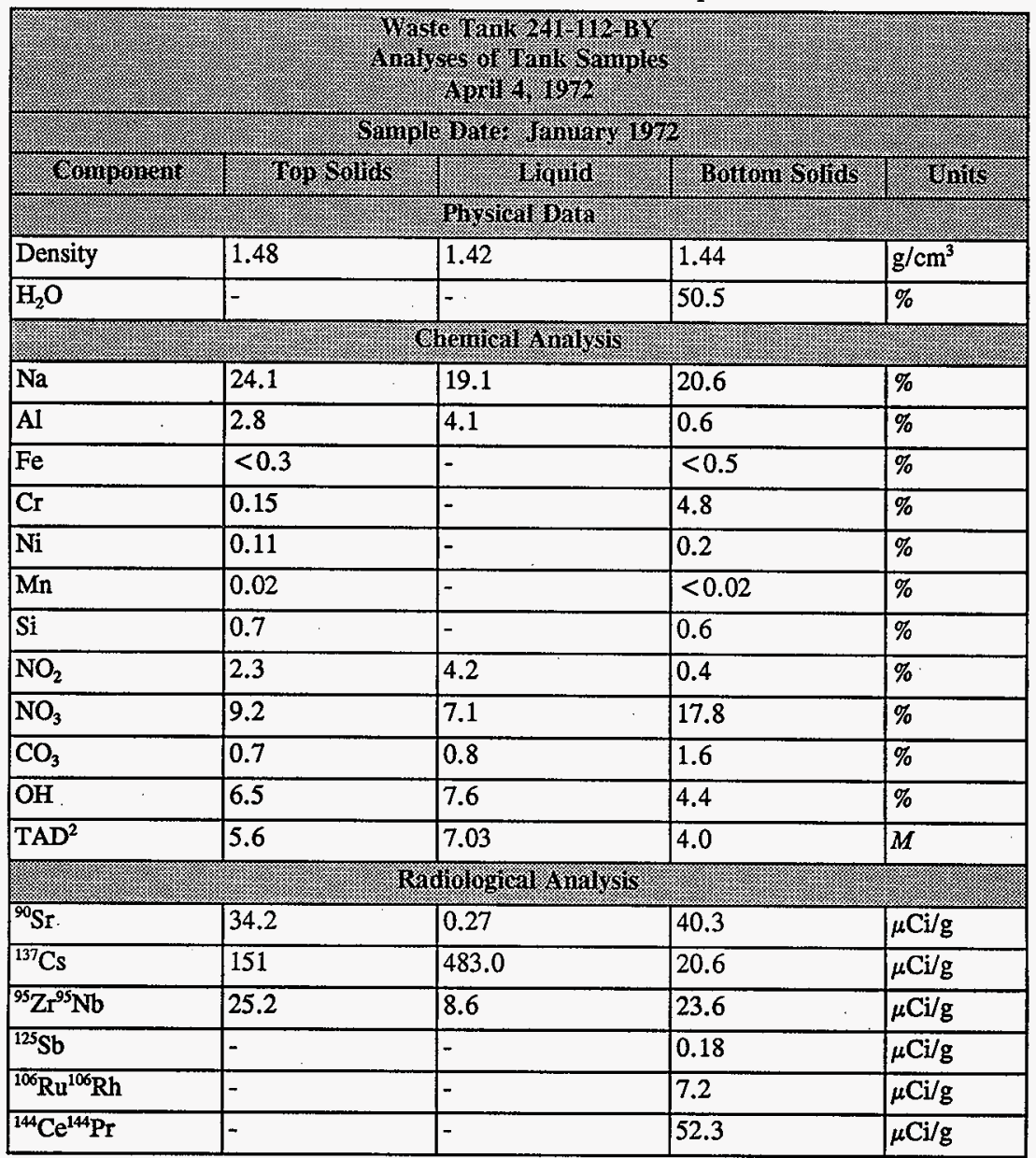

Notes:

${ }^{1}$ Pre-1989 analytical data have not been validated and should be used with caution.

'Total acid demand 
Table B2-61. Tank 241-BY-112 Sample. ${ }^{1}$

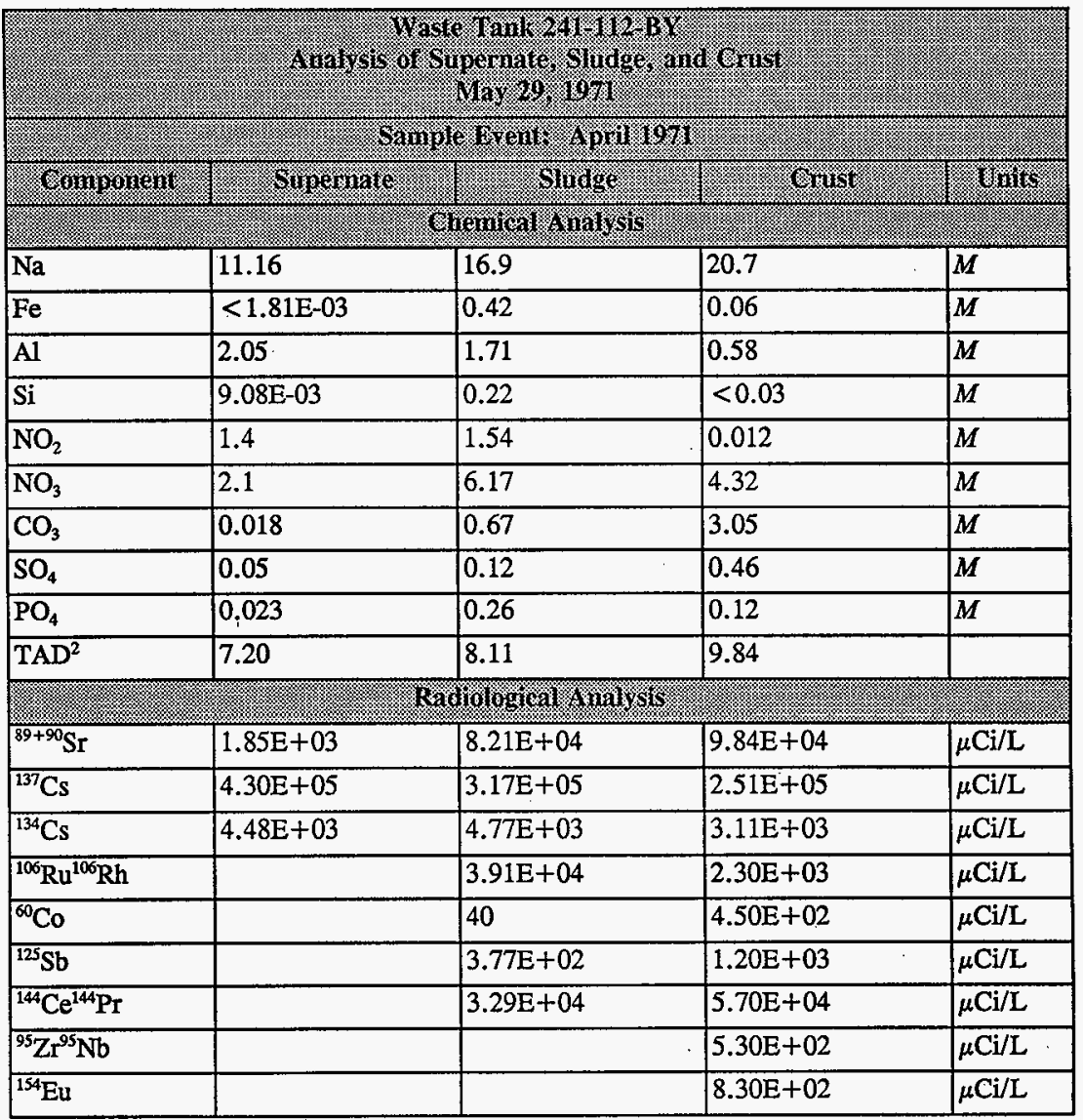

Notes:

'Pre-1989 analytical data have not been validated and should be used with caution.

2Total acid demand 


\section{B3.0 ASSESSMENT OF CHARACTERIZATION RESULTS}

This section discusses the overall quality and consistency of the current sampling results for tank 241-BY-112.

This section also evaluates sampling and analysis factors that may impact data interpretation. These factors are used to assess overall data quality and consistency and to identify limitations in data use.

\section{B3.1 FIELD OBSERVATIONS}

In October, 1996, two push mode core samples were obtained from risers 18 and 21 of tank 241-BY-112. Core 174 from riser 18 contained 6 segments. The second core, core 177 from riser 21 , also contained 6 segments. Sample recovery was poor. Only segments 5 and 6 of core 174 and segments 4 and 5 of core 177 were complete segments, that is, the segments contained material in the upper and lower half of the sampler. These cores show the average saltcake depth beneath the risers is about $279 \mathrm{~cm}(110 \mathrm{in}$.) which confirms the measured depth of $287 \mathrm{~cm}(113 \mathrm{in}$.) as of October 3, 1996, from riser 19. There is no indication of the use of hydrostatic head fluid in procuring these samples. A blank was not provided to the 222-S Laboratory.

\section{B3.2 QUALITY CONTROL ASSESSMENT}

The usual QC assessment includes an evaluation of the appropriate standard recoveries, spike recoveries, duplicate analyses, and blanks that are performed in conjunction with the chemical analyses. All the pertinent QC tests were conducted on the 1996 push mode core samples, allowing a full assessment regarding data accuracy and precision. Baldwin (1997) established the specific criteria for all analytes. Sample and duplicate pairs that had one or more QC results outside the specified criteria are identified by footnotes in the data summary tables.

The standard and spike recovery results provide an estimate of analysis accuracy. If a standard or spike recovery is above or below the given criterion, the analytical results may be biased high or low, respectively. The precision is estimated by the RPD, which is defined as the absolute value of the difference between the primary and duplicate samples, divided by their mean, times 100 . 


\section{B3.2.1 Differential Scanning Calorimetry Analysis}

The RPD between sample and duplicate exceeded 20 percent on eight subsamples (see Table B3-1). Poor precision was caused by sample inhomogeneities. Rerun analyses were not requested.

The chemist noted the exotherms for the lower half of segments 4 of core 174 (S96T005876) indicated the decomposition of a relatively pure substance.

Table B3-1. Differential Scanning Calorimetry Relative Percent Differences Exceeding 20 Percent.

\begin{tabular}{|c|c|c|}
\hline 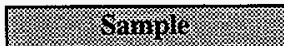 & Sarine Description & 10 \\
\hline S96T005878 & Core 174 , segment 5 , upper half & 65.6 \\
\hline S96T005907 & Core 174 , segment 5 , drainable liquid & 20.7 \\
\hline S96T005880 & Core 174 , segment 6 , upper half & 68.7 \\
\hline S96T005879 & Core 174 , segment 6 , lower half & 127 \\
\hline S96T005919 & Core 177 , segment 3 , lower half & 56.1 \\
\hline S96T005920 & Core 177 , segment 4 , upper half & 54.5 \\
\hline S96T005950 & Core 177 , segment 5 , upper half & 94.6 \\
\hline S96T005960 & Core 177 , segment 5 , drainable liquid & 66.3 \\
\hline
\end{tabular}

\section{B3.2.2 Thermogravimetric Analysis}

A second analysis of the lower half of segment 1 of core 177 (S96T005917) was performed because of the differences in appearance of the thermograms between the sample and duplicate. These differences were not seen in the replicate analysis.

The RPD between sample and duplicate for the lower half of segments 3 of core 177 (S96T005919) was 28.1 percent. Results were near the detection limit of the method, and precision was compromised. Rerun analysis was not requested.

\section{B3.2.3 Density}

Bulk density could not be determined for segment 1 of core 177 (S96T005911) because of subsample dryness. The highest bulk density result of $1.86 \mathrm{~g} / \mathrm{mL}$ was used to calculate the laboratory's solid total alpha activity notification limit for this tank $(33.1 \mu \mathrm{Ci} / \mathrm{g})$. 


\section{B3.2.4 Total Alpha Analysis}

The RPD between sample and duplicate exceeded 20 percent for three subsamples. Segments 1, 3, and 5 for core 174 (S96T005889, S96T005891, and S96T005893) had RPDs of 27.3 percent, 55.1 percent, and 42.3 percent, respectively. A high RPD is caused by low sample alpha activity. Rerun analyses were not requested. In addition, two preparations blanks showed AT activity above the detection level. The activity in these preparation blanks is inconsequential when compared to the results for the samples and is caused by high counting error.

\section{B3.2.5 Total Organic Carbon}

Sample S96T005921 was reanalyzed for QC purposes, and results were below the notification limits. Sample S96T005876 had a spike recovery result of 0.0 percent caused by sample matrix interference.

The RPD between sample and duplicate exceeded 20 percent for four subsamples. Two subsamples, the lower half of segment 5 of core 174 (S96T005877) and the upper half of segment 6 of core 174 (S96T005880) were performed in triplicate. No rerun was requested. The lower half of segments 2 and 3 of core 174 (S96T005874 and S96T005875, respectively) and the upper half of segment 5 of core 177 had RPDs of 59.5 percent, 33.5 percent, and 27.2 percent, respectively. Poor precision was caused by sample heterogeneity. Rerun analyses were not requested. 
In summary, the majority of the QC results were within the boundaries specified in Baldwin (1997). The discrepancies mentioned here and footnoted in the data summary tables should not impact data validity or use.

\section{B3.3 DATA CONSISTENCY CHECKS}

Comparing different analytical methods is useful in assessing data consistency and quality. Several comparisons were possible with the data set provided by the two core samples including a comparison of phosphorous as analyzed by ICP with phosphate as analyzed by IC. In addition, mass and charge balances were calculated to help assess the overall data consistency.

\section{B3.3.1 Comparison of Results from Different Analytical Methods}

The following data consistency checks compare the results from two analytical methods. A close comparison between the two methods strengthens the credibility of both results, whereas a poor comparison brings the reliability of the data into question. See Section B2.0 for analytical mean results.

Sulfate data were measured by IC; sulfur was measured by ICP. This allows a comparison of the IC and ICP results. The mean sulfur result of the fusion-digested sample was $9.80 \mathrm{E}+03 \mu \mathrm{g} / \mathrm{g}$ which included some less than values. This converts to $2.94 \mathrm{E}+04 \mu \mathrm{g} / \mathrm{g}$ of sulfate. This compares with the water-digested IC mean core composite sulphate result of $2.50 \mathrm{E}+04 \mu \mathrm{g} / \mathrm{g}$. The RPD between these two sulfur results was 16 percent. A similar calculation for phosphorous and phosphate was not used because the phosphorous data were below instrument detection levels.

The mean Oxalate IC result was $2.96 \mathrm{E}+04 \mu \mathrm{g} / \mathrm{g}$. This converts to $8.07 \mathrm{E}+03 \mu \mathrm{g} / \mathrm{g}$ TOC which compares well with the mean TOC results of $8.51 \mathrm{E}+03 \mu \mathrm{g} / \mathrm{g}$. This agreement between TOC and Oxalate confirms the low DSC results and shows 95 percent of the organics have degraded to Oxalate which is not reactive.

\section{B3:3.2 Mass and Charge Balance}

The principal objective in performing mass and charge balances is to determine whether the measurements are consistent. In calculating the balances, only analytes listed in Section B2.0 detected at a concentration of $1,000 \mu \mathrm{g} / \mathrm{g}$ or greater were considered. 
Except for sodium, all cations listed in Table B3-2 were assumed to be in their most common hydroxide or oxide form, and the concentrations of the assumed species were calculated stoichiometrically. Because precipitates are neutral species, all positive charge was attributed to the sodium cation. The anions listed in Table B3-3 were assumed to be present as sodium salts and were expected to balance the positive charge exhibited by the cations. Phosphate, as determined by IC, is assumed to be completely water soluble and appears only in the anion mass and charge calculations. The concentrations of cationic species in Table B3-2, the anionic species in Table B3-3, and the percent water were ultimately used to calculate the mass balance. The TOC is assumed to be totally converted to Oxalate and is not included in order to avoid counting it twice.

The mass balance was calculated from the formula below. The factor 0.0001 is the conversion factor from $\mu \mathrm{g} / \mathrm{g}$ to weight percent.

$$
\begin{aligned}
& \text { Mass balance }=\quad \text { Percent Water }+0.0001 \times\{\text { Total Analyte Concentration }\} \\
& =\quad \% \text { Water }+0.0001 \times\left\{\mathrm{Al}(\mathrm{OH})_{4}^{-}+\mathrm{Cr}(\mathrm{OH})_{3}+\mathrm{FeO}(\mathrm{OH})+\mathrm{Na}^{+}+\mathrm{Cl}^{-}\right. \\
& +\mathrm{F}^{-}+\mathrm{NO}_{3}^{-}+\mathrm{NO}_{2}^{-}+\mathrm{PO}_{4}^{-3}+(\mathrm{COO})_{2}^{-2}+ \\
& \left.\mathrm{SiO}_{3}^{-2}+\mathrm{SO}_{4}^{-2}+\mathrm{CO}_{3}^{-2}\right\}
\end{aligned}
$$

The total analyte concentrations calculated from the above equation is $868,000 \mu \mathrm{g} / \mathrm{g}$. The mean weight percent water (obtained from the mean reported in Table B3-4) is 27 percent or $270,000 \mu \mathrm{g} / \mathrm{g}$. The mass balance resulting from adding the percent water to the total analyte concentration is $\mathbf{1 1 3 . 8}$ percent (see Table B3-4).

The following equations demonstrate the derivation of total cations and total anions. The charge balance is the ratio of these two values.

Total cations $(\mu \mathrm{eq} / \mathrm{g})=\left[\mathrm{Na}^{+}\right] / 23=1.45 \mathrm{E}+04 \mu \mathrm{eq} / \mathrm{g}$

Total anions $(\mu \mathrm{eq} / \mathrm{g})=\left[\mathrm{Cl}^{-}\right] / 35+[\mathrm{F}] / 19+\left[\mathrm{NO}_{3}^{-}\right] / 62+\left[\mathrm{NO}_{2}^{-}\right] / 46+$ $2\left[(\mathrm{COO})_{2}^{-2}\right] / 88+3\left[\mathrm{PO}_{4}^{-3}\right] / 95+2\left[\mathrm{SiO}_{3}^{-2}\right] / 76+$ $2\left[\mathrm{SO}_{4}^{-2}\right] / 96+2\left[\mathrm{CO}_{3}^{-2}\right] / 60+\mathrm{Al}(\mathrm{OH})_{4}{ }^{-195}=$ $1.15 \mathrm{E}+04 \mu \mathrm{eq} / \mathrm{g}$

The charge balance obtained by dividing the sum of the positive charge by the sum of the negative charge was 1.26. The lower anion charge may be due to the presence of total hydroxide values, not accounted for in the charge balance calculations.

In summary, the above calculations yield reasonable mass and charge balance values (close to 1.00 for charge balance and 100 percent for mass balance) indicating that the analytical results are generally self-consistent. 
HNF-SD-WM-ER-701 Rev. 0

Table B3-2. Cation Mass and Charge Data.

\begin{tabular}{|c|c|c|c|c|}
\hline 4inger & 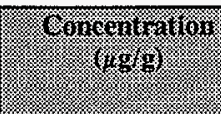 & Stroneries & 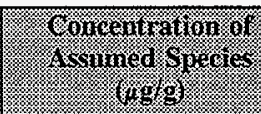 & (19arlis) \\
\hline Chromium & $1.75 \mathrm{E}+04$ & $\mathrm{Cr}(\mathrm{OH})_{3}$ & $3.47 \mathrm{E}+04$ & \\
\hline Iron & $2.96 \mathrm{E}+03$ & $\mathrm{FeO}(\mathrm{OH})$ & $4.92 \mathrm{E}+04$ & \\
\hline Sodium & $3.34 \mathrm{E}+05$ & $\mathrm{Na}^{+}$ & $3.34 \mathrm{E}+05$ & $1.45 \mathrm{E}+04$ \\
\hline \multicolumn{3}{|l|}{ Total } & $4.18 \mathrm{E}+05$ & $1.45 \mathrm{E}+04$ \\
\hline
\end{tabular}

Table B3-3. Anion Mass and Charge Data.

\begin{tabular}{|c|c|c|c|c|}
\hline 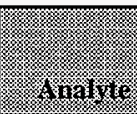 & (2oncenturion & 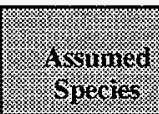 & 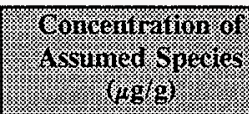 & (1) \\
\hline Aluminate & $1.82 \mathrm{E}+04$ & $\mathrm{Al}(\mathrm{OH})_{4}^{-}$ & $6.40 \mathrm{E}+04$ & $6.74 \mathrm{E}+02$ \\
\hline Chloride & $1.15 \mathrm{E}+03$ & $\mathrm{Cl}^{-}$ & $1.15 \mathrm{E}+03$ & $3.28 \mathrm{E}+01$ \\
\hline Fluoride & $9.41 \mathrm{E}+03$ & $F^{-}$ & $9.41 \mathrm{E}+03$ & $4.95 \mathrm{E}+02$ \\
\hline Nitrate & $7.34 \mathrm{E}+04$ & $\mathrm{NO}_{3}^{-}$ & $7.34 \mathrm{E}+04$ & $1.18 \mathrm{E}+03$ \\
\hline Nitrite & $2.04 \mathrm{E}+04$ & $\mathrm{NO}_{2}^{-}$ & $2.04 \mathrm{E}+04$ & $4.43 \mathrm{E}+02$ \\
\hline Oxalate & $2.96 \mathrm{E}+04$ & $(\mathrm{COO})_{2}^{-2}$ & $2.96 \mathrm{E}+04$ & $6.72 \mathrm{E}+02$ \\
\hline Phosphate & $1.66 \mathrm{E}+04$ & $\mathrm{PO}_{4}^{-3}$ & $1.66 \mathrm{E}+04$ & $5.24 \mathrm{E}+02$ \\
\hline Silicon & $2.43 \mathrm{E}+03$ & $\mathrm{SiO}_{3}^{-2}$ & $6.60 \mathrm{E}+03$ & $1.74 \mathrm{E}+02$ \\
\hline Sulfate & $2.50 \mathrm{E}+04$ & $\mathrm{SO}_{4}^{-2}$ & $2.50 \mathrm{E}+04$ & $5.21 E+02$ \\
\hline TIC & $4.07 E+04$ & $\mathrm{CO}_{3}^{-2}$ & $2.04 \mathrm{E}+05$ & $6.80 \mathrm{E}+03$ \\
\hline \multicolumn{3}{|l|}{ Total } & $4.50 \mathrm{E}+05$ & $1.15 \mathrm{E}+04$ \\
\hline
\end{tabular}


Table B3-4. Mass Balance Totals.

\begin{tabular}{|l|l|}
\hline & \\
\hline Total from Table B3-2 & 418,000 \\
\hline Total from Table B3-3 & 450,000 \\
\hline Percent Water & 270,000 \\
\hline Grand Total & $1,138,000$ \\
\hline
\end{tabular}

\section{B3.4 MEAN CONCENTRATIONS AND CONFIDENCE INTERVALS}

The following evaluation was performed on the analytical data from the samples from tank 241-BY-112.

Because an inventory estimate is needed without comparing it to a threshold value, two-sided 95 percent confidence intervals on the mean inventory are computed. This was done with segment-level data.

The lower and upper limits ( $\mathrm{LL}$ and $\mathrm{UL}$ ) to a two-sided 95 percent confidence interval for the mean are as follows:

$$
\hat{\mu} \pm t_{(d f, 0.02 s)} \times \hat{\sigma}_{\hat{\mu}} .
$$

In these equations, $\hat{\mu}$ is the estimate of the mean concentration, $\hat{\sigma}_{\hat{\mu}}$ is the estimate of the standard deviation of the mean concentration, and $t_{(d f, 0.029}$ is the quantile from Student's $t$ distribution with df degrees of freedom for a two-sided 95 percent confidence interval.

The mean, $\hat{\mu}$, and the standard deviation, $\hat{\sigma}_{\hat{\mu}}$, were estimated using restricted maximum likelihood estimation (REML) methods. The degrees of freedom (df) for tank 241-BY-112, is the number of cores sampled (two) minus one.

\section{B3.4.1 Liquid and Solid Segment Means}

The statistics in this section were based on analytical data from the most recent sampling event of tank 241-BY-112. Analysis of variance (ANOVA) techniques were used to estimate the mean and to calculate confidence limits on the mean for all analytes that had at least 50 percent of reported values above the detection limit. If at least 50 percent of the reported values were above the detection limit, all the data was used in the computations. The 
detection limit was used as the value for nondetected results. No ANOVA estimates were computed for analytes with less than 50 percent detected values. Only arithmetic means were computed for these analytes.

The results given below are ANOVA estimates based on the core segment data from cores 174 and 177 for tank 241-BY-112. Tables B3-5 and B3-6 provide estimates of the mean concentration and confidence interval on the mean concentration for solid segment sample data and for liquid segment sample data, respectively. The lower limit to a 95 percent confidence interval can be negative. Because an actual concentration of less than zero is not possible, the lower limit is reported as zero, whenever this occurred.

Table B3-5. 95 Percent Two-Sided Confidence Interval for the Mean Concentration for Solid Segment Sample Data. (2 sheets)

\begin{tabular}{|c|c|c|c|c|c|c|}
\hline 18. & 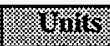 & 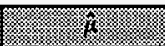 & N & (6) & (x) & (6) \\
\hline \% water & $\%$ & $2.70 \mathrm{E}+01$ & $2.65 \mathrm{E}+00$ & 1 & $0.00 \mathrm{E}+00$ & $6.08 \mathrm{E}+01$ \\
\hline DSC-dry & $\mathrm{J} / \mathrm{g}$ & $9.61 \mathrm{E}+01$ & $2.29 \mathrm{E}+01$ & 1 & $0.00 \mathrm{E}+00$ & $3.87 \mathrm{E}+02$ \\
\hline Bulk density & $\mathrm{g} / \mathrm{mL}$ & $1.46 \mathrm{E}+00$ & $1.08 \mathrm{E}-01$ & 1 & $8.18 \mathrm{E}-02$ & $2.83 \mathrm{E}+00$ \\
\hline Alpha & $\mu \mathrm{Ci} / \mathrm{g}$ & $7.46 \mathrm{E}-02$ & $2.03 \mathrm{E}-02$ & 1 & $0.00 E+00$ & $3.33 \mathrm{E}-01$ \\
\hline ICP.f.Ag ${ }^{1}$ & $\mu \mathrm{g} / \mathrm{g}$ & $<2.04 \mathrm{E}+02$ & $\mathrm{n} / \mathrm{a}$ & $\mathrm{n} / \mathrm{a}$ & $\mathrm{n} / \mathrm{a}$ & $n / a$ \\
\hline ICP.f.Al & $\mu \mathrm{g} / \mathrm{g}$ & $1.82 \mathrm{E}+04$ & $6.24 \mathrm{E}+03$ & 1 & $0.00 \mathrm{E}+00$ & $9.76 \mathrm{E}+04$ \\
\hline ICP.f.As ${ }^{1}$ & $\mu \mathrm{g} / \mathrm{g}$ & $<2.04 \mathrm{E}+03$ & $\mathrm{n} / \mathrm{a}$ & $\mathrm{n} / \mathrm{a}$ & $\mathrm{n} / \mathrm{a}$ & $\mathrm{n} / \mathrm{a}$ \\
\hline ICP.f.B ${ }^{1}$ & $\mu \mathrm{g} / \mathrm{g}$ & $<1.02 \mathrm{E}+03$ & $n / a$ & $\mathrm{n} / \mathrm{a}$ & $\mathrm{n} / \mathrm{a}$ & $\mathrm{n} / \mathrm{a}$ \\
\hline ICP.f.Ba ${ }^{1}$ & $\mu \mathrm{g} / \mathrm{g}$ & $<1.02 \mathrm{E}+03$ & $\mathrm{n} / \mathrm{a}$ & $\mathrm{n} / \mathrm{a}$ & $\mathrm{n} / \mathrm{a}$ & $\mathrm{n} / \mathrm{a}$ \\
\hline ICP.f.Be & $\mu \mathrm{g} / \mathrm{g}$ & $<1.02 \mathrm{E}+02$ & $\mathrm{n} / \mathrm{a}$ & $n / a$ & $\mathrm{n} / \mathrm{a}$ & $n / a$ \\
\hline ICP.f.Bi ${ }^{1}$ & $\mu \mathrm{g} / \mathrm{g}$ & $<2.04 \mathrm{E}+03$ & $n / a$ & $n / a$ & $n / a$ & $n / a$ \\
\hline ICP.f.Ca ${ }^{1}$ & $\mu \mathrm{g} / \mathrm{g}$ & $<2.04 \mathrm{E}+03$ & $n / a$ & $\mathrm{n} / \mathrm{a}$ & $n / a$ & $n / a$ \\
\hline ICP.f.Cd ${ }^{1}$ & $\mu \mathrm{g} / \mathrm{g}$ & $<1.11 \mathrm{E}+02$ & $n / a$ & $n / a$ & $\mathrm{n} / \mathrm{a}$ & $n / a$ \\
\hline ICP.f.Ce ${ }^{1}$ & $\mu \mathrm{g} / \mathrm{g}$ & $<2.04 \mathrm{E}+03$ & $n / a$ & $\mathrm{n} / \mathrm{a}$ & $n / a$ & $n / a$ \\
\hline ICP.f.Co ${ }^{1}$ & $\mu \mathrm{g} / \mathrm{g}$ & $<4.07 \mathrm{E}+02$ & $\mathrm{n} / \mathrm{a}$ & $\mathrm{n} / \mathrm{a}$ & $\mathrm{n} / \mathrm{a}$ & $\mathrm{n} / \mathrm{a}$ \\
\hline ICP.f.Cr & $\mu \mathrm{g} / \mathrm{g}$ & $1.75 \mathrm{E}+04$ & $4.01 \mathrm{E}+03$ & 1 & $0.00 \mathrm{E}+00$ & $6.85 \mathrm{E}+04$ \\
\hline ICP.f.Cu ${ }^{1}$ & $\mu \mathrm{g} / \mathrm{g}$ & $<2.04 \mathrm{E}+02$ & $\mathrm{n} / \mathrm{a}$ & $\mathrm{n} / \mathrm{a}$ & $\mathrm{n} / \mathrm{a}$ & $n / a$ \\
\hline ICP.f.Fe ${ }^{2}$ & $\mu \mathrm{g} / \mathrm{g}$ & $2.96 \mathrm{E}+03$ & $5.71 \mathrm{E}+02$ & 1 & $0.00 \mathrm{E}+00$ & $1.02 \mathrm{E}+04$ \\
\hline ICP.f.La ${ }^{1}$ & $\mu \mathrm{g} / \mathrm{g}$ & $<1.02 \mathrm{E}+03$ & $n / a$ & $n / a$ & $\mathrm{n} / \mathrm{a}$ & $n / a$ \\
\hline ICP.f. $\mathrm{Li}^{1}$ & $\mu \mathrm{g} / \mathrm{g}$ & $<2.04 \mathrm{E}+02$ & $n / a$ & $\mathrm{n} / \mathrm{a}$ & $\mathrm{n} / \mathrm{a}$ & $n / a$ \\
\hline ICP.f.Mg ${ }^{1}$ & $\mu \mathrm{g} / \mathrm{g}$ & $<2.04 \mathrm{E}+03$ & $n / a$ & $n / a$ & $\mathrm{n} / \mathrm{a}$ & $\mathrm{n} / \mathrm{a}$ \\
\hline ICP.f.Mn ${ }^{1}$ & $\mu \mathrm{g} / \mathrm{g}$ & $<2.92 \mathrm{E}+02$ & $\mathrm{n} / \mathrm{a}$ & $n / a$ & $\mathrm{n} / \mathrm{a}$ & $n / a$ \\
\hline ICP.f.Mo' & $\mu \mathrm{g} / \mathrm{g}$ & $<1.02 \mathrm{E}+03$ & $n / a$ & $n / a$ & $\mathrm{n} / \mathrm{a}$ & $n / a$ \\
\hline
\end{tabular}


Table B3-5. 95 Percent Two-Sided Confidence Interval for the Mean Concentration for Solid Segment Sample Data. (2 sheets)

\begin{tabular}{|c|c|c|c|c|c|c|}
\hline A. & Conits & i i & $8 \%$ & (if: & (1) & (1) \\
\hline ICP.f.Na & $\mu \mathrm{g} / \mathrm{g}$ & $3.34 \mathrm{E}+05$ & $3.66 \mathrm{E}+04$ & 1 & $0.00 \mathrm{E}+00$ & $7.99 \mathrm{E}+05$ \\
\hline ICP.f.Nd ${ }^{1}$ & $\mu \mathrm{g} / \mathrm{g}$ & $<2.04 \mathrm{E}+03$ & $n / a$ & $\mathrm{n} / \mathrm{a}$ & $n / \mathbf{a}$ & $\mathrm{n} / \mathrm{a}$ \\
\hline ICP.f.P ${ }^{1}$ & $\mu \mathrm{g} / \mathrm{g}$ & $<7.77 \overline{\mathrm{E}+03}$ & $n / a$ & $n / a$ & $n / a$ & $\mathrm{n} / \mathrm{a}$ \\
\hline ICP.f.Pb ${ }^{1}$ & $\mu \mathrm{g} / \mathrm{g}$ & $<2.04 \mathrm{E}+03$ & $n / a$ & $n / a$ & $n / a$ & $\mathrm{n} / \mathrm{a}$ \\
\hline ICP.f.S ${ }^{2}$ & $\mu \mathrm{g} / \mathrm{g}$ & $9.80 \mathrm{E}+03$ & $2.75 \mathrm{E}+03$ & 1 & $0.00 \mathrm{E}+00$ & $4.48 \mathrm{E}+04$ \\
\hline ICP.f.Sb ${ }^{1}$ & $\mu \mathrm{g} / \mathrm{g}$ & $<1.22 \mathrm{E}+03$ & $\mathrm{n} / \mathrm{a}$ & $n / a$ & $\mathrm{n} / \mathrm{a}$ & $\mathrm{n} / \mathrm{a}$ \\
\hline ICP.f.Se ${ }^{l}$ & $\mu \mathrm{g} / \mathrm{g}$ & $<2.38 \mathrm{E}+03$ & $n / a$ & $n / a$ & $n / a$ & $\mathrm{n} / \mathrm{a}$ \\
\hline ICP.f.Si ${ }^{2}$ & $\mu \mathrm{g} / \mathrm{g}$ & $2.43 \mathrm{E}+03$ & $2.97 \mathrm{E}+02$ & 1 & $0.00 \mathrm{E}+00$ & $6.21 \mathrm{E}+03$ \\
\hline ICP.f.Sm ${ }^{1}$ & $\mu \mathrm{g} / \mathrm{g}$ & $<2.04 \mathrm{E}+03$ & $\mathrm{n} / \mathrm{a}$ & $\mathrm{n} / \mathrm{a}$ & $n / a$ & $n / a$ \\
\hline ICP.f.Sr ${ }^{1}$ & $\mu \mathrm{g} / \mathrm{g}$ & $<2.04 \mathrm{E}+02$ & $n / a$ & $n / a$ & $\mathrm{n} / \mathrm{a}$ & $\mathrm{n} / \mathrm{a}$ \\
\hline ICP.f.Ti $^{1}$ & $\mu \mathrm{g} / \mathrm{g}$ & $<2.04 \mathrm{E}+02$ & $n / a$ & $\mathrm{n} / \mathrm{a}$ & $\mathrm{n} / \mathrm{a}$ & $n / a$ \\
\hline ICP.f.T1 $^{1}$ & $\mu \mathrm{g} / \mathrm{g}$ & $<4.07 \mathrm{E}+03$ & $n / a$ & $\mathrm{n} / \mathrm{a}$ & $\mathrm{n} / \mathrm{a}$ & $\mathrm{n} / \mathbf{a}$ \\
\hline ICP.f.U $\mathrm{U}^{1}$ & $\mu \mathrm{g} / \mathrm{g}$ & $<1.02 \mathrm{E}+04$ & $n / a$ & $n / a$ & $n / a$ & $n / a$ \\
\hline ICP.f. $V^{1}$ & $\mu \mathrm{g} / \mathrm{g}$. & $<1.02 \mathrm{E}+03$ & $n / a$ & $n / a$ & $\mathrm{n} / \mathrm{a}$ & $\mathrm{n} / \mathbf{a}$ \\
\hline ICP.f. $\mathrm{Zn}^{1}$ & $\mu \mathrm{g} / \mathrm{g}$ & $<2.23 \mathrm{E}+02$ & $n / a$ & $n / a$ & $n / a$ & $n / a$ \\
\hline ICP.f. $\mathrm{Zr}^{1}$ & $\mu \mathrm{g} / \mathrm{g}$ & $<2.04 \mathrm{E}+02$ & $n / a$ & $n / a$ & $\mathrm{n} / \mathrm{a}$ & $n / a$ \\
\hline Bromide $^{1}$ & $\mu \mathrm{g} / \mathrm{g}$ & $<7.31 \mathrm{E}+02$ & $\mathrm{n} / \mathrm{a}$ & $n / a$ & $n / a$ & $n / a$ \\
\hline Chloride & $\mu \mathrm{g} / \mathrm{g}$ & $1.15 \mathrm{E}+03$ & $3.14 \mathrm{E}+02$ & 1 & $0.00 \mathrm{E}+00$ & $5.14 \mathrm{E}+03$ \\
\hline Fluoride & $\mu \mathrm{g} / \mathrm{g}$ & $9.41 \mathrm{E}+03$ & $3.25 \mathrm{E}+03$ & 1 & $0.00 \mathrm{E}+00$ & $5.07 \mathrm{E}+04$ \\
\hline Nitrate & $\mu \mathrm{g} / \mathrm{g}$ & $7.34 \mathrm{E}+04$ & $1.67 \mathrm{E}+04$ & 1 & $0.00 \mathrm{E}+00$ & $2.85 \mathrm{E}+05$ \\
\hline Nitrite & $\mu \mathrm{g} / \mathrm{g}$ & $2.04 \mathrm{E}+04$ & $5.80 \mathrm{E}+03$ & 1 & $0.00 \mathrm{E}+00$ & $9.42 \mathrm{E}+04$ \\
\hline Oxalate $^{2}$ & $\mu \mathrm{g} / \mathrm{g}$ & $2.96 \mathrm{E}+04$ & $1.02 \mathrm{E}+04$ & 1 & $0.00 \mathrm{E}+00$ & $1.60 \mathrm{E}+05$ \\
\hline Phosphate $^{2}$ & $\mu \mathrm{g} / \mathrm{g}$ & $1.66 \mathrm{E}+04$ & $8.55 \mathrm{E}+03$ & 1 & $0.00 \mathrm{E}+00$ & $1.25 \mathrm{E}+05$ \\
\hline Sulfate & $\mu \mathrm{g} / \mathrm{g}$ & $2.50 \mathrm{E}+04$ & $8.23 \mathrm{E}+03$ & 1 & $0.00 \mathrm{E}+00$ & $1.30 \mathrm{E}+05$ \\
\hline TIC & $\mu \mathrm{g} / \mathrm{g}$ & $4.07 \mathrm{E}+04$ & $8.50 \mathrm{E}+03$ & 1 & $0.00 \mathrm{E}+00$ & $1.49 \mathrm{E}+05$ \\
\hline TOC & $\mu \mathrm{g} / \mathrm{g}$ & $8.51 \mathrm{E}+03$ & $2.53 \mathrm{E}+03$ & 1 & $0.00 \mathrm{E}+00$ & $4.05 \mathrm{E}+04$ \\
\hline
\end{tabular}

Notes:

'More than 50 percent of the analytical results were less than values; therefore, confidence intervals were not computed.

${ }^{2}$ Some "less-than" values are in the analytical results. 
HNF-SD-WM-ER-701 Rev. 0

Table B3-6. 95 Percent Two-Sided Confidence Interval for the Mean Concentration for Liquid Segment Sample Data. (2 sheets)

\begin{tabular}{|c|c|c|c|c|c|c|}
\hline Arial be & Sying & 14: & $8.8 \%$ & ir & 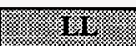 & (1) \\
\hline$\%$ water & $\%$ & $4.85 \mathrm{E}+01$ & $1.58 \mathrm{E}-01$ & 1 & $4.65 \mathrm{E}+01$ & $5.05 E+01$ \\
\hline DSC-dry & $\mathrm{J} / \mathrm{g}$ & $1.40 \mathrm{E}+02$ & $3.37 \mathrm{E}+01$ & 1 & $0.00 \mathrm{E}+00$ & $5.68 \mathrm{E}+02$ \\
\hline Specific gravity & $\mathrm{g} / \mathrm{mL}$ & $1.47 \mathrm{E}+00$ & $5.00 \mathrm{E}-03$ & 1 & $1.41 \mathrm{E}+00$ & $1.53 \mathrm{E}+00$ \\
\hline Alpha $^{1}$ & $\mu \mathrm{Ci} / \mathrm{mL}$ & $<1.63 \mathrm{E}-02$ & $n / a$ & $n / a$ & $n / a$ & $\mathrm{n} / \mathrm{a}$ \\
\hline ICP.a.Ag & $\mu \mathrm{g} / \mathrm{mL}$ & $1.76 \mathrm{E}+01$ & $3.25 \mathrm{E}-01$ & 1 & $1.35 \mathrm{E}+01$ & $2.18 \mathrm{E}+01$ \\
\hline ICP.a. $A^{1}$ & $\mu \mathrm{g} / \mathrm{mL}$ & $5.55 \mathrm{E}+04$ & $1.15 \mathrm{E}+03$ & 1 & $4.08 \mathrm{E}+04$ & $7.01 E+04$ \\
\hline ICP.a.As ${ }^{1}$ & $\mu \mathrm{g} / \mathrm{mL}$ & $<6.01 \mathrm{E}+01$ & $n / a$ & $n / a$ & $n / a$ & $n / a$ \\
\hline ICP.a.B & $\mu \mathrm{g} / \mathrm{mL}$ & $3.74 \mathrm{E}+01$ & $2.27 \mathrm{E}+00$ & 1 & $8.47 \mathrm{E}+00$ & $6.63 \mathrm{E}+01$ \\
\hline ICP.a.Ba ${ }^{1}$ & $\mu \mathrm{g} / \mathrm{mL}$ & $<3.01 \mathrm{E}+01$ & $n / a$ & $n / a$ & $n / a$ & $\mathrm{n} / \mathrm{a}$ \\
\hline ICP.a.Be ${ }^{1}$ & $\mu \mathrm{g} / \mathrm{mL}$ & $<3.00 \mathrm{E}+00$ & $n / a$ & $n / a$ & $\mathrm{n} / \mathbf{a}$ & $n / a$ \\
\hline ICP.a.Bi ${ }^{1}$ & $\mu \mathrm{g} / \mathrm{mL}$ & $<6.01 \mathrm{E}+01$ & $n / a$ & $n / a$ & $\mathrm{n} / \mathrm{a}$ & $\mathrm{n} / \mathrm{a}$ \\
\hline ICP.a. $\mathrm{Ca}^{1}$ & $\mu \mathrm{g} / \mathrm{mL}$ & $<6.01 \mathrm{E}+01$ & $n / a$ & $n / a$ & $n / a$ & $n / a$ \\
\hline ICP.a.Cd ${ }^{1}$ & $\mu \mathrm{g} / \mathrm{mL}$ & $<3.00 \mathrm{E}+00$ & $n / a$ & $n / a$ & $n / \mathbf{a}$ & $n / a$ \\
\hline ICP.a.Ce ${ }^{1}$ & $\mu \mathrm{g} / \mathrm{mL}$ & $<6.01 \mathrm{E}+01$ & $n / a$ & $n / a$ & $n / a$ & $n / a$ \\
\hline ICP.a.Co ${ }^{1}$ & $\mu \mathrm{g} / \mathrm{mL}$ & $<1.20 \mathrm{E}+01$ & $n / a$ & $n / a$ & $n / a$ & $n / a$ \\
\hline ICP.a.Cr & $\mu \mathrm{g} / \mathrm{mL}$ & $1.10 \mathrm{E}+04$ & $2.21 \mathrm{E}+03$ & 1 & $0.00 \mathrm{E}+00$ & $3.91 \mathrm{E}+04$ \\
\hline ICP.a.Cu ${ }^{1}$ & $\mu \mathrm{g} / \mathrm{mL}$ & $<6.01 \mathrm{E}+00$ & $n / a$ & $n / a$ & $\mathrm{n} / \mathrm{a}$ & $\mathrm{n} / \mathrm{a}$ \\
\hline ICP.a.Fe $^{1}$ & $\mu \mathrm{g} / \mathrm{mL}$ & $<3.01 \mathrm{E}+01$ & $n / \mathbf{a}$ & $n / a$ & $n / a$ & $\mathrm{n} / \mathrm{a}$ \\
\hline ICP.a.K & $\mu \mathrm{g} / \mathrm{mL}$ & $1.01 \mathrm{E}+04$ & $9.00 E+01$ & 1 & $8.97 \mathrm{E}+03$ & $1.13 \mathrm{E}+04$ \\
\hline ICP.a.La ${ }^{1}$ & $\mu \mathrm{g} / \mathrm{mL}$ & $<3.01 \mathrm{E}+01$ & $n / a$ & $n / a$ & $n / a$ & $n / a$ \\
\hline ICP.a.Li ${ }^{1}$ & $\mu \mathrm{g} / \mathrm{mL}$ & $<6.01 \mathrm{E}+00$ & $n / a$ & $n / a$ & $n / a$ & $n / a$ \\
\hline ICP.a.Mg $\mathbf{M g}^{1}$ & $\mu \mathrm{g} / \mathrm{mL}$ & $<6.01 \mathrm{E}+01$ & $n / a$ & $n / a$ & $n / a$ & $n / a$ \\
\hline ICP.a.Mn ${ }^{1}$ & $\mu \mathrm{g} / \mathrm{mL}$ & $<6.01 \mathrm{E}+00$ & $n / a$ & $n / a$ & $n / a$ & $n / a$ \\
\hline ICP.a.Mo & $\mu \mathrm{g} / \mathrm{mL}$ & $9.77 \mathrm{E}+01$ & $2.05 \mathrm{E}+00$ & 1 & $7.17 \mathrm{E}+01$ & $1.24 \mathrm{E}+02$ \\
\hline ICP.a.Na & $\mu \mathrm{g} / \mathrm{mL}$ & $2.44 \mathrm{E}+05$ & $6.29 \mathrm{E}+02$ & 1 & $2.36 \mathrm{E}+05$ & $2.52 \mathrm{E}+05$ \\
\hline ICP.a.Nd ${ }^{1}$ & $\mu \mathrm{g} / \mathrm{mL}$ & $<6.01 \mathrm{E}+01$ & $\mathrm{n} / \mathrm{a}$ & $\mathrm{n} / \mathrm{a}$ & $\mathrm{n} / \mathrm{a}$ & $n / a$ \\
\hline ICP.a.Ni ${ }^{1}$ & $\mu \mathrm{g} / \mathrm{mL}$ & $<1.20 \mathrm{E}+01$ & $\mathrm{n} / \mathrm{a}$ & $\mathrm{n} / \mathrm{a}$ & $n / a$ & $n / a$ \\
\hline ICP.a.P & $\mu \mathrm{g} / \mathrm{mL}$ & $3.92 \mathrm{E}+02$ & $6.00 \mathrm{E}+00$ & 1 & $3.15 \mathrm{E}+02$ & $4.68 \mathrm{E}+02$ \\
\hline ICP.a.Pb ${ }^{1}$ & $\mu \mathrm{g} / \mathrm{mL}$ & $<6.01 \mathrm{E}+01$ & $\mathrm{n} / \mathrm{a}$ & $n / a$ & $\mathrm{n} / \mathrm{a}$ & $\mathrm{n} / \mathrm{a}$ \\
\hline ICP.a.S & $\mu \mathrm{g} / \mathrm{mL}$ & $3.27 \mathrm{E}+02$ & $3.33 \mathrm{E}+00$ & 1 & $2.84 \mathrm{E}+02$ & $3.69 \mathrm{E}+02$ \\
\hline
\end{tabular}


Table B3-6. 95 Percent Two-Sided Confidence Interval for the Mean Concentration for Liquid Segment Sample Data. (2 sheets)

\begin{tabular}{|c|c|c|c|c|c|c|}
\hline 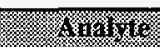 & rinits: & $\%$ & l. & ill & $111=$ & 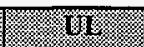 \\
\hline ICP.a.Sb & $\mu \mathrm{g} / \mathrm{mL}$ & $<3.61 \mathrm{E}+01$ & $n / a$ & $n / a$ & $n / a$ & $n / a$ \\
\hline ICP.a.Se ${ }^{1}$ & $\mu \mathrm{g} / \mathrm{mL}$ & $<6.01 \mathrm{E}+01$ & $n / a$ & $\mathrm{n} / \mathbf{a}$ & $n / a$ & $n / a$ \\
\hline ICP.a.Si & $\mu \mathrm{g} / \mathrm{mL}$ & $4.19 \mathrm{E}+02$ & $2.63 \mathrm{E}+01$ & 1 & $8.57 \mathrm{E}+01$ & $7.53 \mathrm{E}+02$ \\
\hline ICP.a.Sm ${ }^{1}$ & $\mu \mathrm{g} / \mathrm{mL}$ & $<6.01 \mathrm{E}+01$ & $n / a$ & $\mathrm{n} / \mathrm{a}$ & $n / a$ & $\mathrm{n} / \mathrm{a}$ \\
\hline ICP.a.Sr ${ }^{1}$ & $\mu \mathrm{g} / \mathrm{mL}$ & $<6.01 \mathrm{E}+00$ & $\mathrm{n} / \mathrm{a}$ & $n / a$ & $n / a$ & $n / a$ \\
\hline${\text { ICP.a. } \text { Ti }^{1}}^{1}$ & $\mu \mathrm{g} / \mathrm{mL}$ & $<6.01 \mathrm{E}+00$ & $n / a$ & $n / a$ & $n / a$ & $n / a$ \\
\hline ICP.a.T ${ }^{1}$ & $\mu \mathrm{g} / \mathrm{mL}$ & $<1.20 \mathrm{E}+02$ & $n / a$ & $\mathrm{n} / \mathrm{a}$ & $n / a$ & $n / a$ \\
\hline ICP.a.U $U^{1}$ & $\mu \mathrm{g} / \mathrm{mL}$ & $<3.00 \mathrm{E}+02$ & $n / a$ & $n / a$ & $n / a$ & $\mathrm{n} / \mathrm{a}$ \\
\hline$\overline{\text { ICP.a.V }}{ }^{1}$ & $\mu \mathrm{g} / \mathrm{mL}$ & $<3.01 \mathrm{E}+01$ & $n / a$ & $n / a$ & $\mathrm{n} / \mathrm{a}$ & $n / a$ \\
\hline ICP.a. $\mathrm{Zn}^{1}$ & $\mu \mathrm{g} / \mathrm{mL}$ & $<6.01 \mathrm{E}+00$ & $n / a$ & $n / a$ & $n / a$ & $n / a$ \\
\hline ICP.a. $\mathrm{Zr}^{1}$ & $\mu \mathrm{g} / \mathrm{mL}$ & $<6.01 \mathrm{E}+00$ & $n / a$ & $\mathrm{n} / \mathrm{a}$ & $n / a$ & $n / a$ \\
\hline Bromide $^{1}$ & $\mu \mathrm{g} / \mathrm{mL}$ & $<9.62 \mathrm{E}+02$ & $n / a$ & $\mathrm{n} / \mathrm{a}$ & $n / a$ & $n / a$ \\
\hline Chloride & $\mu \mathrm{g} / \mathrm{mL}$ & $9.04 \mathrm{E}+03$ & $1.36 \mathrm{E}+03$ & 1 & $0.00 \mathrm{E}+00$ & $2.63 E+04$ \\
\hline Fluoride & $\mu \mathrm{g} / \mathrm{mL}$ & $6.94 \mathrm{E}+02$ & $7.30 \mathrm{E}+01$ & 1 & $0.00 \mathrm{E}+00$ & $1.62 \mathrm{E}+03$ \\
\hline Nitrate & $\mu \mathrm{g} / \mathrm{mL}$ & $1.90 \mathrm{E}+05$ & $1.92 \mathrm{E}+04$ & 1 & $0.00 \mathrm{E}+00$ & $4.35 \mathrm{E}+05$ \\
\hline Nitrite & $\mu \mathrm{g} / \mathrm{mL}$ & $1.40 \mathrm{E}+05$ & $9.00 \mathrm{E}+03$ & 1 & $2.56 \mathrm{E}+04$ & $2.54 \mathrm{E}+05$ \\
\hline Oxalate $^{2}$ & $\mu \mathrm{g} / \mathrm{mL}$ & $3.32 \mathrm{E}+03$ & $2.52 \mathrm{E}+03$ & 1 & $0.00 \mathrm{E}+00$ & $3.53 \mathrm{E}+04$ \\
\hline Phosphate $^{2}$ & $\mu \mathrm{g} / \mathrm{mL}$ & $1.48 \mathrm{E}+03$ & $1.23 \mathrm{E}+02$ & 1 & $0.00 \mathrm{E}+00$ & $3.04 \mathrm{E}+03$ \\
\hline Sulfate $^{2}$ & $\mu \mathrm{g} / \mathrm{mL}$ & $5.93 \mathrm{E}+03$ & $3.85 \mathrm{E}+03$ & 1 & $0.00 \mathrm{E}+00$ & $5.49 \mathrm{E}+04$ \\
\hline TIC & $\mu \mathrm{g} / \mathrm{mL}$ & $1.54 \mathrm{E}+03$ & $7.75 \mathrm{E}+01$ & 1 & $5.58 \mathrm{E}+02$ & $2.53 \mathrm{E}+03$ \\
\hline $\mathrm{TOC}^{3}$ & $\mu \mathrm{g} / \mathrm{mL}$ & $1.72 \mathrm{E}+03$ & $1.97 \mathrm{E}+02$ & 1 & $0.00 \mathrm{E}+00$ & $4.23 \mathrm{E}+03$ \\
\hline
\end{tabular}

Notes:

'More than 50 percent of the analytical results were less than values; therefore, confidence intervals were not computed.

${ }^{2}$ Some "less-than" values are in the analytical results.

${ }^{3}$ Wet basis 


\section{B3.4.2 Analysis of Variance Models}

A statistical model is needed to account for the spatial and measurement variability in $\hat{\sigma}_{\hat{p}}$. This cannot be done using an ordinary standard deviation of the data (Snedecor and Cochran 1980).

The statistical model fit to the liquid segment data and bulk density data is as follows:

$$
\begin{gathered}
Y_{i j}=\mu+C_{i}+A_{i j}, \\
i=1^{12}, \ldots, a, j=1^{12}, \ldots, b_{i},
\end{gathered}
$$

where

$$
\begin{aligned}
& \mathbf{Y}_{\mathrm{ij}}=\text { laboratory results from the } \mathrm{j}^{\text {th }} \text { duplicate from the } \mathrm{i}^{\mathrm{th}} \text { core in the tank } \\
& \mu \quad=\text { the grand mean } \\
& \mathrm{C}_{\mathrm{i}}=\text { the effect of the } i^{\text {th }} \text { core } \\
& A_{i j}=\text { the effect of the } j^{\text {th }} \text { analytical result from the } i^{\text {th }} \text { core } \\
& \text { a }=\text { the number of cores } \\
& b_{i}=\text { the number of analytical results from the } i^{\text {it }} \text { core }
\end{aligned}
$$

The variable $C_{i}$ is assumed to be a random effect. This variable and $A_{i j}$ are assumed to be uncorrelated and normally distributed with means zero and variances $\sigma^{2}(\mathrm{C})$ and $\sigma^{2}(\mathrm{~A})$, respectively. Estimates of $\sigma^{2}(\mathrm{C})$ and $\sigma^{2}(\mathrm{~A})$ were obtained using REML techniques. This method, applied to variance component estimation, is described in Harville (1977). The statistical results were obtained using the statistical analysis package S-PLUS ${ }^{1}$ (Statistical Science 1993).

The statistical model fit to the solid segment data for alpha is as follows:

$$
\begin{gathered}
\mathrm{Y}_{\mathrm{ijk}}=\mu+\mathrm{C}_{\mathrm{i}}+\mathrm{S}_{\mathrm{ij}}+\mathrm{A}_{\mathrm{ijk},} \\
\mathrm{i}=1^{12}, \ldots, \mathrm{a}, \mathrm{j}=1^{12}, \ldots, \mathrm{b}_{\mathrm{i}}, \mathrm{k}=1^{12}, \ldots \mathrm{c}_{\mathrm{ij}}
\end{gathered}
$$

where

$$
\begin{aligned}
& Y_{i j k}=\text { laboratory results from the } k^{\text {th }} \text { duplicate from the } j^{\text {th }} \text { segment in the } i^{\text {th }} \\
& \text { core in the tank } \\
& \mu \quad=\quad \text { the grand mean } \\
& \mathrm{C}_{\mathrm{i}}=\text { the effect of the } \mathrm{i}^{\text {th }} \text { core }
\end{aligned}
$$

\footnotetext{
${ }^{1}$ S-PLUS is a registered trademark of Statistical Sciences, Seattle, WA.
} 
$S_{i j}=$ the effect of the $j^{\text {th }}$ segment from the $i^{\text {th }}$ core

$A_{i j k}=$ the effect of the $k^{\text {th }}$ analytical result from the $j^{\text {th }}$ segment from the $i^{\text {th }}$ core

a $=$ the number of cores

$b_{i}=$ the number of segments from the $i^{\text {th }}$ core

$c_{i j}=$ the number of analytical results from the $j^{\text {th }}$ segment from the $i^{\text {th }}$ core

The variables $C_{i}$ and $S_{i j}$ are assumed to be a random effect. This variable and $A_{i j}$ are assumed to be uncorrelated and normally distributed with means zero and variances $\sigma^{2}(C)$, $\sigma^{2}(\mathrm{~S})$, and $\sigma^{2}(\mathrm{~A})$, respectively. Estimates of $\sigma^{2}(\mathrm{C}), \sigma^{2}(\mathrm{~S})$, and $\sigma^{2}(\mathrm{~A})$ were obtained using REML techniques. This method, applied to variance component estimation, is described in Harville (1977). The statistical results were obtained using the statistical analysis package S-PLUS $^{\oplus}$ (Statistical Science 1993).

The statistical model fit to the remaining solid segment data is as follows:

$$
\begin{gathered}
\mathrm{Y}_{\mathrm{ijkm}}=\mu+\mathrm{C}_{\mathrm{i}}+\mathrm{S}_{\mathrm{ij}}+\mathrm{L}_{\mathrm{ijk}}+\mathrm{A}_{\mathrm{ijkm},}, \\
\mathrm{i}=1^{12}, \ldots, \mathrm{a}, \mathrm{j}=1^{12}, \ldots, \mathrm{b}_{\mathrm{i}}, \mathrm{k}=1, \ldots, \mathrm{c}_{\mathrm{ij}}, \mathrm{m}=1, \ldots, \mathrm{d}_{\mathrm{j} \mathbf{k}}
\end{gathered}
$$

where

$$
\begin{aligned}
& \mathrm{Y}_{\mathrm{ijkm}}=\text { laboratory results from the } \mathrm{m}^{\text {th }} \text { duplicate in the } \mathrm{k}^{\text {th }} \text { location in the } \mathrm{j}^{\text {th }} \\
& \text { segment in the } \mathrm{i}^{\text {th }} \text { core in the tank } \\
& \mu \quad=\quad \text { the grand mean } \\
& \mathrm{C}_{\mathrm{i}}=\text { the effect of the } \mathrm{i}^{\text {th }} \text { core } \\
& S_{i j}=\text { the effect of the } j^{\text {th }} \text { segment in the } i^{\text {th }} \text { core } \\
& L_{i j k}=\text { the effect of the } k^{\text {th }} \text { location in the } j^{\text {th }} \text { segment in the } i^{\text {th }} \text { core } \\
& A_{i j k m}=\quad \text { the effect of the } m^{\text {th }} \text { duplicate result in the } k^{\text {th }} \text { location in the } j^{\text {th }} \text { segment } \\
& \text { in the } \mathrm{i}^{\text {th }} \text { core } \\
& \text { a }=\text { the number of cores } \\
& b_{i}=\text { the number of segments in the } i^{\text {th }} \text { core } \\
& c_{i j}=\text { the number of locations from the } j^{\text {th }} \text { segment in the } i^{\text {th }} \text { core }
\end{aligned}
$$


$\mathrm{d}_{\mathrm{iik}}=$ the number of analytical results from the $\mathrm{k}^{\text {th }}$ location in the $\mathrm{j}^{\text {th }}$ segment in the $\mathrm{i}^{\text {th }}$ core

The variable $\mathrm{C}_{\mathrm{i}}, \mathrm{S}_{\mathrm{ij}}$, and $\mathrm{L}_{\mathrm{ijk}}$ are assumed to be random effects. These variables and $\mathrm{A}_{\mathrm{ijkm}}$ are assumed to be uncorrelated and normally distributed with means zero and variances $\sigma^{2}(C)$, $\sigma^{2}(\mathrm{~S}), \sigma^{2}(\mathrm{~L})$, and $\sigma^{2}(\mathrm{~A})$, respectively. Estimates of $\sigma^{2}(\mathrm{C}), \sigma^{2}(\mathrm{~S}), \sigma^{2}(\mathrm{~L})$, and $\sigma^{2}(\mathrm{~A})$ were obtained using REML methods. This method, applied to variance component estimation, is described in Harville (1977). The statistical results were obtained using statistical analysis package S-PLUS ${ }^{\circledR}$ (Statistical Science 1993).

\section{B4.0 APPENDIX B REFERENCES}

Baldwin, J. H., 1997, Tank 241-BY-112 Push Mode Core Sampling and Analysis Plan, WHC-SD-WM-TSAP-110, Rev. 0A, Lockheed Martin Hanford Corporation for Fluor Daniel Hanford, Inc., Richland, Washington.

Buckingham, J. S., 1971, Dissolution and Analysis of 112-BY Sludge and Crust Samples, (letter to D. J. Larkin, G. C. Oberg, and W. C. Schmidt, May 29), Atlantic Richfield Hanford Company, Richland, Washington.

Buckingham, J. S., 1972, Analysis of Tank 112-By Sample, (letter to T. D. Anderson, April 4), Atlantic Richfield Hanford Company, Richland, Washington.

Cash, R. J., 1996a, Application of "Flammable Gas Tank Safety Program Data Requirements for Core Sampling Analysis Developed Through the Data Quality Objectives Process, Rev. 2 (internal memorandum 79300-96-028, to S. J. Eberlein, July 12), Westinghouse Hanford Company, Richland, Washington.

Cash, R. J. 1996b Scope Increase of Data Quality Objectives to Support Resolution of the Organic Complexant Safety Issue, Rev. 2 (internal memorandum 79300-96-029 to S. J. Eberlein, July 12), Westinghouse Hanford Company, Richland, Washington.

DOE-RL, 1996, Recommendation 93-5 Implementation Plan, DOE/RL-94-0001, Rev. 1, U.S. Department of Energy, Richland, Washington.

DeLorenzo, D. S., J. H. Rutherford, D. J. Smith, D. B. Hiller, K. W. Johnson, and B. C. Simpson, 1994, Tank Characterization Reference Guide, WHC-SD-WM-TI-648, Rev. 0, Westinghouse Hanford Company, Richland, Washington.

Dukelow, G. T., J. W. Hunt, H. Babad, and J. E Meacham, 1995, Tank Safety Screening Data Quality Objective, WHC-SD-WM-SP-004, Rev. 2, Westinghouse Hanford Company, Richland, Washington. 
Harville, D. A., 1977, "Maximum Likelihood Approaches to Variance Component Estimation and to Related Problems," Journal of the American Statistical Association, pp. 320-340.

Homi, C. S. 1994, Tank 241-BY-112 Tank Characterization Plan, WHC-SD-WM-TP-281, Rev. 0, Westinghouse Hanford Company, Richland, Washington.

Huckaby, J. L., and D. R. Bratzel, 1995, Tank 241-BY-112 Headspace Gas and Vapor Characterization Results for Samples Collected in November 1994, WHC-SD-WM-ER-441, Rev. 1A, Westinghouse Hanford Company, Richland, Washington.

Nuzum, J. L., 1997, Tank 241-BY-112, Cores 174 and 177 Analytical Results for the Final Report, HNF-SD-WM-DP-229, Rev. 0, Rust Federal Services of Hanford Inc. for Fluor Daniel Hanford, Inc., Richland, Washington.

Osborne, J. W. and L. L. Buckley, 1995, Data Quality Objectives for Tank Hazardous Vapor Safety Screening, WHC-SD-WM-DQO-002, Rev. 1, Westinghouse Hanford Company, Richland, Washington.

Snedecor, G. W., and W. G. Cochran, 1980, Statistical Methods, 7th Edition, Iowa State University Press, Ames, Iowa.

Statistical Sciences, 1993, S-PLUS Reference Manual, Version 3.2, Seattle: Statistical Science is a division of MathSoft, Inc.), Statistical Sciences, Inc., Seattle, Washington. 
HNF-SD-WM-ER-701 Rev. 0

APPENDIX C

STATISTICAL ANALYSIS FOR ISSUE RESOLUTION 
HNF-SD-WM-ER-701 Rev. 0

This page intentionally left blank.

C-2 


\section{APPENDIX C \\ STATISTICAL ANALYSIS FOR ISSUE RESOLUTION}

Appendix $\mathrm{C}$ contains information on the data investigations required for the applicable DQOs for tank 241-BY-112, and it documents the results of statistical and other numerical manipulations required in the DQOs. The analyses required for tank 241-BY-112 are reported below.

\section{C1.0 STATISTICS FOR SAFETY SCREENING DQO}

The safety screening DQO (Dukelow et al. 1995) defines acceptable decision confidence limits in terms of one-sided 95 percent confidence intervals. In this appendix, one-sided confidence limits supporting the safety screening DQO are calculated for tank 241-BY-112. All data in this section are from the final laboratory data package for the 1996 core sampling event for tank 241-BY-112 (Nuzum 1997).

Confidence intervals were computed for each sample number from tank 241-BY-112 analytical data. Tables C1-1 and C1-2 show the sample numbers and confidence intervals for alpha and DSC, respectively.

The UL of a one-sided 95 percent confidence interval on the mean is as follows:

$$
\hat{\mu}+t_{(d f, 0.05)} * \hat{\sigma}_{\hat{\mu}}
$$

In this equation, $\hat{\mu}$ is the arithmetic mean of the data, $\hat{\sigma}_{\hat{\mu}}$ is the estimate of the standard deviation of the mean, and $t_{(a f, 0.05)}$ is the quantile from Student's $t$ distribution with df degrees of freedom for a one-sided 95 percent confidence interval.

For tank 241-BY-112 data (per sample number), df equals the number of observations minus one.

Table C1-1 lists the UL of the 95 percent confidence interval for each sample number based on alpha data. Each confidence interval can be used to make the following statement. If the UL is less than $41 \mu \mathrm{Ci} / \mathrm{g}(61.5 \mu \mathrm{Ci} / \mathrm{mL}$ for liquid), reject the null hypothesis that the alpha is greater than or equal to $41 \mu \mathrm{Ci} / \mathrm{g}(61.5 \mu \mathrm{Ci} / \mathrm{mL}$ for liquid) at the 0.05 level of significance. Because no tank 241-BY-112 UL alpha results exceeded the threshold limits, criticality is not a concern.

Table C1-2 lists the UL of the 95 percent confidence interval for each sample number based on DSC data. Each confidence interval can be used to make the following statement. If the 
UL is less than $480 \mathrm{~J} / \mathrm{g}$, reject the null hypothesis that DSC is greater than or equal to $480 \mathrm{~J} / \mathrm{g}$ at the 0.05 level of significance. All measurements are well below the limit. Three samples exceeded the 95 percent confidence interval upper limit of $480 \mathrm{~J} / \mathrm{g}$ because of sample heterogeneity. However, because moisture content ranged from 33 to 37 percent for these segments (well above the threshold of 17 percent) and because total organic carbon is low, energetics is not a concern for this tank.

Table C1-1. 95 Percent Confidence Interval Upper Limits for Alpha for Tank 241-BY-112. (Units are $\mu \mathrm{Ci} / \mathrm{g}$ or $\mu \mathrm{Ci} / \mathrm{mL}$ )

\begin{tabular}{|c|c|c|c|c|}
\hline 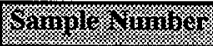 & Sample Oescriptior: & 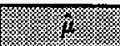 & 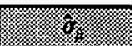 & (6) \\
\hline S96T005889 & Core 174 , segment 1 , lower half & $1.01 \mathrm{E}-01$ & $1.38 \mathrm{E}-02$ & $1.88 \mathrm{E}-01$ \\
\hline S96T005890 & Core 174 , segment 2 , lower half & $3.01 \mathrm{E}-02$ & $2.55 \mathrm{E}-03$ & $4.62 \mathrm{E}-02$ \\
\hline S96T005891 & Core 174 , segment 3 , lower half & $5.15 \mathrm{E}-02$ & $1.42 \mathrm{E}-02$ & $1.41 \mathrm{E}-01$ \\
\hline S96T005892 & Core 174 , segment 4 , lower half & $2.58 \mathrm{E}-01$ & $2.15 \mathrm{E}-02$ & 3.93E-01 \\
\hline S96T005893 & Core 174 , segment 5 , lower half & $5.49 \mathrm{E}-02$ & $1.16 \mathrm{E}-02$ & $1.28 \mathrm{E}-01$ \\
\hline S96T005895 & Core 174 , segment 6 , lower half & $6.23 \mathrm{E}-02$ & $5.00 \mathrm{E}-04$ & $6.55 \mathrm{E}-02$ \\
\hline S96T005929 & Core 177 , segment 1 , lower half & $2.32 \mathrm{E}-03$ & $0.00 E+00$ & $2.32 \mathrm{E}-03$ \\
\hline S96T005930 & Core 177 , segment 2 , lower half & $3.79 \mathrm{E}-02$ & $2.35 \mathrm{E}-03$ & $5.27 \mathrm{E}-02$ \\
\hline S96T005931 & Core 177 , segment 3 , lower half & $4.86 \mathrm{E}-02$ & $1.10 \mathrm{E}-03$ & $5.55 \mathrm{E}-02$ \\
\hline S96T005933 & Core 177 , segment 4 , lower half & $1.64 \mathrm{E}-01$ & $1.00 \mathrm{E}-02$ & $2.27 \mathrm{E}-01$ \\
\hline S96T005957 & Core 177 , segment 5 , lower half & $4.55 \mathrm{E}-02$ & $4.50 \mathrm{E}-04$ & $4.83 \mathrm{E}-02$ \\
\hline S96T005934 & Core 177 , segment 6 , lower half & $3.95 \mathrm{E}-02$ & $4.50 \mathrm{E}-04$ & $4.23 \mathrm{E}-02$ \\
\hline
\end{tabular}


Table C1-2. 95 Percent Confidence Interval Upper Limits for Differential Scanning Calorimetry Exotherms for Tank 241-BY-112 (J/g Dry).

\begin{tabular}{|c|c|c|c|c|}
\hline 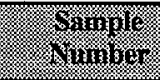 & 㖶 & & 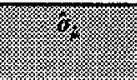 & 11 \\
\hline S96T005873 & Core 174 , segment 1 , lower half & $0.00 \mathrm{E}+00$ & $0.00 \mathrm{E}+00$ & $0.00 \mathrm{E}+00$ \\
\hline 5967005874 & ore 174 , segment 2 , lower half & $0.00 \mathrm{E}+00$ & $0.00 \mathrm{E}+00$ & $0.00 \mathrm{E}+\infty 0$ \\
\hline 596T005875 & ore 174 , segment 3 , lower half & $0.00 \mathrm{E}+00$ & $0.00 \mathrm{E}+00$ & $0.00 \mathrm{E}+00$ \\
\hline $96 \mathrm{~T} 005876$ & Core 174 , segment 4 , lower half & $1.72 \mathrm{E}+02$ & $3.50 \mathrm{E}+00$ & $1.94 \mathrm{E}+02$ \\
\hline 967005907 & Core 174 , segment 5 , drainable liquid & $1.74 \mathrm{E}+02$ & $1.80 \mathrm{E}+01$ & $2.88 \mathrm{E}+02$ \\
\hline S96T005878 & Core 174 , segment 5 , upper half & $2.67 \mathrm{E}+02$ & $8.75 \mathrm{E}+01$ & $8.19 \mathrm{E}+02$ \\
\hline$\$ 96 \mathrm{~T} 005877$ & egment 5 , lower half & $1.09 \mathrm{E}+02$ & $2.00 \mathrm{E}+00$ & $1.22 \mathrm{E}+02$ \\
\hline$\$ 96 \mathrm{~T} 005880$ & Core 174 , segment 6 , upper half & $1.65 \mathrm{E}+02$ & $5.65 \mathrm{E}+01$ & $5.21 E+02$ \\
\hline S96T005879 & Core 174 , segment 6 , lower half & $2.07 \mathrm{E}+01$ & $1.32 \mathrm{E}+01$ & $1.04 \mathrm{E}+02$ \\
\hline S96T005917 & Core 177 , segment 1 , lower half & $0.00 \mathrm{E}+00$ & $0.00 \mathrm{E}+00$ & $0.00 \mathrm{E}+00$ \\
\hline S96T005918 & Core 177 , segment 2 , lower half & $0.00 \mathrm{E}+00$ & $0.00 \mathrm{E}+00$ & $0.00 \mathrm{E}+00$ \\
\hline S96T005919 & Core 177 , segment 3 , lower half & $1.30 \mathrm{E}+02$ & $3.66 \mathrm{E}+01$ & $3.61 \mathrm{E}+02$ \\
\hline S96T005920 & Core 177 , segment 4 , upper half & $1.15 \mathrm{E}+02$ & $3.13 \mathrm{E}+01$ & $3.12 \mathrm{E}+02$ \\
\hline S96T005921 & Core 177 , segment 4 , lower half & $2.20 \mathrm{E}+02$ & $1.75 \mathrm{E}+01$ & $3.30 \mathrm{E}+02$ \\
\hline S96T005960 & Core 177 , segment 5 , drainable liquid & $1.07 \mathrm{E}+02$ & $3.54 \mathrm{E}+01$ & $3.30 \mathrm{E}+02$ \\
\hline S96T005950 & Core 177 , segment 5 , upper half & $1.45 \mathrm{E}+02$ & $6.87 \mathrm{E}+01$ & $5.79 \mathrm{E}+02$ \\
\hline S96T005951 & Core 177 , segment 5 , lower half & $1.76 \mathrm{E}+02$ & $1.00 \mathrm{E}+01$ & $2.39 \mathrm{E}+02$ \\
\hline S96T005922 & Core 177 , segment 6 , lower half & $7.65 \mathrm{E}+01$ & $5.30 \mathrm{E}+00$ & $1.10 \mathrm{E}+02$ \\
\hline
\end{tabular}




\section{C2.0 STATISTICS FOR THE ORGANIC DATA QUALITY OBJECTIVE}

The organic DQO (Turner et al. 1995) defines acceptable decision confidence limits in terms of one-sided 95 percent confidence intervals. This appendix calculates those one-sided confidence limits for tank 241-BY-112. All data considered are from the final laboratory data package for the 1996 core sampling event for tank 241-BY-112 (Nuzum 1997).

Confidence intervals were computed for each sample number from tank 241-BY-112 analytical data. Tables $\mathrm{C} 1-3$ and $\mathrm{C} 1-4$ show the sample numbers and confidence intervals for percent water and TOC, respectively.

For percent water, the lower limit (LL) of a one-sided 95 percent confidence interval for the mean is

$$
\hat{\mu}-\mathrm{t}_{(\mathrm{df}, 0.09)} * \hat{\sigma}_{\hat{\mu}}
$$

and for TOC, the upper limit (UL) of a one-sided 95 percent confidence interval for the mean is

$$
\hat{\mu}+\mathrm{t}_{(\mathrm{dr}, 0.05)} * \hat{\sigma}_{\hat{\mu}} .
$$

For these equations, $\hat{\mu}$ is the arithmetic mean of the data, $\hat{\sigma}_{\hat{\mu}}$ is the estimate of the standard deviation of the mean, and $t_{(d r, 0,0)}$ is the quantile from Student's $t$ distribution with df degrees of freedom for a one-sided 95 percent confidence interval.

For tank 241-BY-112 data (per sample number), df equals the number of observations minus one.

Table C1-3 lists the LL of the 95 percent confidence interval for each sample number based on percent water data. Each confidence interval can be used to make the following statement. If the $L L$ is greater than 17 percent, reject the null hypothesis that the percent water is less than or equal to 17 percent at the 0.05 level of significance. Six samples were below the 95 percent confidence interval LL of 17 percent. However, the DSCs for the same samples were below the DSC limit of $480 \mathrm{~J} / \mathrm{g}$.

Table C1-4 lists the upper limit of the 95 percent confidence interval for each sample number based on TOC data. Each confidence interval can be used to make the following statement. If the upper limit is less than $30,000 \mu \mathrm{g} / \mathrm{g}$, reject the null hypothesis that TOC is greater than or equal to $30,000 \mu \mathrm{g} / \mathrm{g}$ at the 0.05 level of significance. The units for TOC drainable liquid samples were converted from $\mu \mathrm{g} / \mathrm{mL}$ to $\mu \mathrm{g} / \mathrm{g}$ using the specific gravity results for each sample number. Three samples exceeded the 95 percent confidence interval UL of $30,000 \mu \mathrm{g} / \mathrm{g}$. The DSCs for these same samples were low, indicating the TOC has degraded and is not reactive. 
Table C1-3. 95 Percent Confidence Interval Lower Limits for Percent Water for Tank 241-BY-112 (Units are in Percents).

\begin{tabular}{|l|l|c|c|c|}
\hline $\begin{array}{c}\text { Sample } \\
\text { Number }\end{array}$ & \multicolumn{1}{|c|}{ Description } & $\hat{\mu}$ & $\hat{\boldsymbol{\sigma}}$ & \\
\hline S96T005873 & Core 174, segment 1, lower half & $2.37 \mathrm{E}+01$ & $1.43 \mathrm{E}+00$ & $1.47 \mathrm{E}+01$ \\
\hline S96T005874 & Core 174, segment 2, lower half & $1.44 \mathrm{E}+01$ & $1.50 \mathrm{E}-02$ & $1.43 \mathrm{E}+01$ \\
\hline S96T005875 & Core 174, segment 3, lower half & $1.47 \mathrm{E}+01$ & $9.80 \mathrm{E}-01$ & $8.48 \mathrm{E}+00$ \\
\hline S96T005876 & Core 174, segment 4, lower half & $2.33 \mathrm{E}+01$ & $1.15 \mathrm{E}-01$ & $2.26 \mathrm{E}+01$ \\
\hline S96T005907 & $\begin{array}{l}\text { Core 174, segment 5, drainable } \\
\text { liquid }\end{array}$ & $4.84 \mathrm{E}+01$ & $3.15 \mathrm{E}-01$ & $4.64 \mathrm{E}+01$ \\
\hline S96T005877 & Core 174, segment 5, lower half & $4.27 \mathrm{E}+01$ & $8.70 \mathrm{E}-01$ & $3.72 \mathrm{E}+01$ \\
\hline S96T005878 & Core 174, segment 5, upper half & $3.40 \mathrm{E}+01$ & $1.95 \mathrm{E}-01$ & $3.27 \mathrm{E}+01$ \\
\hline S96T005879 & Core 174, segment 6, lower half & $3.30 \mathrm{E}+01$ & $7.00 \mathrm{E}-02$ & $3.25 \mathrm{E}+01$ \\
\hline S96T005880 & Core 174, segment 6, upper half & $3.72 \mathrm{E}+01$ & $3.50 \mathrm{E}-01$ & $3.50 \mathrm{E}+01$ \\
\hline S96T005917 & Core 177, segment 1, lower half & $3.59 \mathrm{E}+01$ & $4.77 \mathrm{E}+00$ & $2.47 \mathrm{E}+01$ \\
\hline S96T005918 & Core 177, segment 2, lower half & $1.54 \mathrm{E}+01$ & $3.65 \mathrm{E}-01$ & $1.31 \mathrm{E}+01$ \\
\hline S96T005919 & Core 177, segment 3, lower half & $1.85 \mathrm{E}+01$ & $2.60 \mathrm{E}+00$ & $2.10 \mathrm{E}+00$ \\
\hline S96T005921 & Core 177, segment 4, lower half & $3.66 \mathrm{E}+01$ & $2.20 \mathrm{E}-01$ & $3.53 \mathrm{E}+01$ \\
\hline S96T005920 & Core 177, segment 4, upper half & $1.99 \mathrm{E}+01$ & $1.61 \mathrm{E}+00$ & $9.72 \mathrm{E}+00$ \\
\hline S96T005960 & $\begin{array}{l}\text { Core 177, segment 5, drainable } \\
\text { liquid }\end{array}$ & $4.87 \mathrm{E}+01$ & $7.50 \mathrm{E}-02$ & $4.82 \mathrm{E}+01$ \\
\hline S96T005951 & Core 177, segment 5, lower half & $4.02 \mathrm{E}+01$ & $1.40 \mathrm{E}-01$ & $3.93 \mathrm{E}+01$ \\
\hline S96T005950 & Core 177, segment 5, upper half & $3.35 \mathrm{E}+01$ & $1.23 \mathrm{E}+00$ & $2.58 \mathrm{E}+01$ \\
\hline S96T005922 & Core 177, segment 6, lower half & $2.87 \mathrm{E}+01$ & $1.03 \mathrm{E}+00$ & $2.22 \mathrm{E}+01$ \\
\hline
\end{tabular}


Table C1-4. 95 Percent Confidence Interval Upper Limits for TOC for Tank 241-BY-112. (Units are in $\mu \mathrm{g} / \mathrm{g}$-Dry)

\begin{tabular}{|c|c|c|c|c|}
\hline Siminger & Deserinining & & & צIII- \\
\hline S96T005873 & Core 174 , segment 1 , lower half & $1.55 \mathrm{E}+03$ & $5.90 \mathrm{E}+01$ & $1.93 \mathrm{E}+03$ \\
\hline S96T005874 & Core 174 , segment 2 , lower half & $6.29 \mathrm{E}+02$ & $1.87 \mathrm{E}+02$ & $1.81 \mathrm{E}+03$ \\
\hline S96T005875 & Core 174 , segment 3 , lower half & $1.29 \mathrm{E}+03$ & $2.15 \mathrm{E}+02$ & $2.64 \mathrm{E}+03$ \\
\hline S96T005876 & Core 174 , segment 4 , lower half & $4.24 \mathrm{E}+04$ & $2.35 \mathrm{E}+03$ & $5.72 \mathrm{E}+04$ \\
\hline S96T005907 & $\begin{array}{l}\begin{array}{l}\text { Core } 174, \text { segment } 5 \text {, drainable } \\
\text { liquid }\end{array} \\
\end{array}$ & $2.51 \mathrm{E}+03$ & $3.28 \mathrm{E}+01$ & $2.72 \mathrm{E}+03$ \\
\hline S96T005877 & Core 174, segment 5 , lower half & $1.12 \mathrm{E}+04$ & $1.20 \mathrm{E}+03$ & $1.47 \mathrm{E}+04$ \\
\hline S96T005878 & Core 174 , segment 5, upper half & $2.14 \mathrm{E}+04$ & $7.57 \mathrm{E}+01$ & $2.19 \mathrm{E}+04$ \\
\hline S96T005879 & Core 174 , segment 6 , lower half & $2.32 \mathrm{E}+03$ & $7.46 \mathrm{E}+00$ & $2.37 \mathrm{E}+03$ \\
\hline S96T005880 & Core 174 , segment 6 , upper half & $1.19 \mathrm{E}+04$ & $6.53 \mathrm{E}+02$ & $1.38 \mathrm{E}+04$ \\
\hline S96T005917 & Core 177 , segment 1 , lower half & $2.07 \mathrm{E}+03$ & $1.01 \mathrm{E}+02$ & $2.71 E+03$ \\
\hline S96T005918 & Core 177 , segment 2 , lower half & $9.77 \mathrm{E}+02$ & $9.10 \mathrm{E}+01$ & $1.55 \mathrm{E}+03$ \\
\hline S96T005919 & Core 177 , segment 3 , lower half & $6.57 \mathrm{E}+02$ & $2.39 \mathrm{E}+01$ & $8.09 \mathrm{E}+02$ \\
\hline S96T005921 & Core 177 , segment 4 , lower half & $4.35 \mathrm{E}+04$ & $3.55 \mathrm{E}+03$ & $6.59 \mathrm{E}+04$ \\
\hline S96T005920 & Core 177 , segment 4 , upper half & $8.37 \mathrm{E}+03$ & $7.80 \mathrm{E}+02$ & $1.33 \mathrm{E}+04$ \\
\hline S96T005960 & $\begin{array}{l}\text { Core } 177 \text {, segment } 5 \text {, drainable } \\
\text { liquid }\end{array}$ & $2.02 \mathrm{E}+03$ & $1.33 \mathrm{E}+01$ & $2.10 \mathrm{E}+03$ \\
\hline \$96T005951 & Core 177 , segment 5 , lower half & $1.44 \mathrm{E}+04$ & $2.76 \mathrm{E}+02$ & $1.61 \mathrm{E}+04$ \\
\hline S96T005950 & Core 177 , segment 5 , upper half & $3.10 \mathrm{E}+04$ & $4.21 \mathrm{E}+03$ & $5.76 \mathrm{E}+04$ \\
\hline S96T005922 & Core 177 , segment 6 , lower half & $6.57 \mathrm{E}+03$ & $7.71 \mathrm{E}+01$ & $7.06 \mathrm{E}+03$ \\
\hline
\end{tabular}




\section{C3.0 APPENDIX C REFERENCES}

Dukelow, G. T., J. W. Hunt, H. Babad, and J. E Meacham, 1995, Tank Safety Screening Data Quality Objective, WHC-SD-WM-SP-004, Rev. 2, Westinghouse Hanford Company, Richland, Washington.

Nuzum, J. L., 1997, Tank 241-BY-112, Cores 174 and 177 Analytical Results for the Final Report, HNF-SD-WM-DP-229, Rev. 0, Rust Federal Services of Hanford Inc. for Fluor Daniel Hanford, Inc., Richland, Washington.

Turner, D. Ȧ., H. Babad, L. L. Buckley, and J. E. Meacham, 1995, Data Quality Objective to Support Resolution of the Organic Complexant Safety Issue, WHC-SD-WM-DQO-006, Rev. 2, Westinghouse Hanford Company, Richland, Washington. 
HNF-SD-WM-ER-701 Rev. 0

This page intentionally left blank. 
HNF-SD-WM-ER-701 Rev. 0

APPENDIX D

EVALUATION TO ESTABLISH BEST-BASIS INVENTORY

FOR SINGLE-SHELL TANK 241-BY-112

D-1 
HNF-SD-WM-ER-701 Rev. 0

This page intentionally left blank.

D-2 


\section{APPENDIX D \\ EVALUATION TO ESTABLISH BEST-BASIS INVENTORY FOR SINGLE-SHELL TANK 241-BY-112}

An effort is underway to provide waste inventory estimates that will serve as standard characterization source terms for the various waste management activities (Hodgson and LeClair 1996). As part of this effort, an evaluation of available information for single-shell tank 241-BY-112 was performed, and a best-basis inventory was established. This work follows the methodology that was established by the standard inventory task.

\section{D1.0 CHEMICAL INFORMATION SOURCES}

Available waste (chemical) information for tank 241-BY-112 includes the following:

- Data from recent analyses of two partial push-mode core samples that were collected in October, 1996 (see Appendix B).

- The inventory estimate for this tank (Agnew et al. 1997) generated from the HDW model developed at Los Alamos National Laboratory.

- Tank Characterization Report data from other tanks historically identified as having the same BY saltcake waste type. For specific tanks and references, see Section D3.3.

\section{D2.0 COMPARISON OF COMPONENT INVENTORY VALUES}

Tables 2-1 and 2-2 compare sample-based inventories derived from the analytical concentration data from the core samples and the HDW model inventories. Table D2-1 compares nonradioactive components on a kilogram $(\mathrm{kg})$ basis, and Table D2-2 compares the radioactive components on a total curie basis. The HDW model document (Agnew et al. 1997) provides tank content estimates in terms of component concentrations and inventories. The chemical species are reported without charge designation according to the best basis inventory convention.

The sample-based inventories listed in the TCR were calculated by multiplying the mean concentration of an analyte by the current waste mass, derived using the current tank volume 
and the mean density of the waste. However, the sample data are based on incomplete core samples. (A full profile of the waste was not obtained.) The tank is reported by Hanlon (1997) to contain $1,101 \mathrm{~kL}(291 \mathrm{kgal})$ total waste consisting of $1,082 \mathrm{~kL}$ (286 kgal) saltcake and $18.9 \mathrm{~kL}$ ( $5 \mathrm{kgal}$ ) sludge. The mean density is reported to be $1.46 \mathrm{~g} / \mathrm{mL}$ (see Appendix B).

The HDW model inventory is also based on a waste volume of $1,101 \mathrm{~kL}$ (291 kgal), but it assumes a higher density than observed for the samples $(1.63 \mathrm{~g} / \mathrm{mL})$. The waste in the HDW model is partitioned as follows: $1,071 \mathrm{~kL}$ (283 kgal) BY saltcake, $22.7 \mathrm{~kL}$ (6 kgal) sludge from ferrocyanide scavenging (PFeCN), and $7.6 \mathrm{~kL}(2 \mathrm{kgal})$ metal waste sludge.

The sample-based inventory was developed by assuming that the unsampled last portion of waste at the tank bottom had the same mean concentrations as did the rest of the tank. It is possible that a small layer of PFeCN and metal waste sludge remains in the tank bottom, but no reliable documentation is available to support this assumption. The assumption used for this assessment is that there is no sludge layer at the tank bottom. The potential sludge layer is only a small portion of this tank's waste volume ( $<3$ percent). Only a sample taken at the tank bottom will indicate if this is correct.

Table D2-1. Sample-Based and Hanford Defined Waste-Based Inventory Estimates for Nonradioactive Components in Tank 241-BY-112. (2 sheets)

\begin{tabular}{|c|c|c|c|c|c|}
\hline tinating & $\begin{array}{l}\text { Sampling } \\
\text { hivenioyt }\end{array}$ & 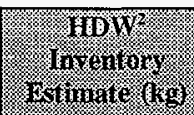 & 4inige & 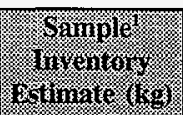 & 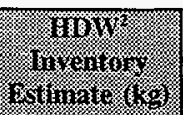 \\
\hline Al & 31,000 & 61,100 & $\mathrm{NO}_{3}$ & 124,000 & 450,000 \\
\hline $\mathrm{Bi}$ & $<3,270$ & 1,550 & $\mathrm{OH}$ & NR & 180,000 \\
\hline $\mathrm{Ca}$ & $<3,270$ & 3,430 & oxalate & 47,700 & 0.253 \\
\hline $\mathrm{Cl}$ & 2,110 & 5,030 & $\mathrm{~Pb}$ & $<3,270$ & 1,260 \\
\hline $\mathrm{Cr}$ & 28,400 & 3,070 & $\mathrm{P}$ as $\mathrm{PO}_{4}$ & 26,700 & 8,030 \\
\hline $\mathrm{F}^{\mathrm{c}}$ & 15,100 & 1,180 & $\mathrm{Si}$ & 3,910 & 2,350 \\
\hline$\overline{\mathrm{Fe}}$ & 4,760 & 2,570 & $\mathrm{~S}$ as $\mathrm{SO}_{4}$ & 40,400 & 20,100 \\
\hline $\mathrm{Hg}$ & NR & 7.79 & $\mathrm{Sr}$ & $<327$ & 0 \\
\hline K & NR & 1,680 & TIC as $\mathrm{CO}_{3}$ & 326,000 & 33,700 \\
\hline $\mathrm{La}$ & $<1,640$ & 0.304 & TOC & 13,700 & 7,920 \\
\hline Mn & $<469$ & 191 & $U_{\text {TOTAL }}$ & $<16,400$ & 10,000 \\
\hline $\mathrm{Na}$ & 543,000 & 330,000 & $\mathrm{Zr}$ & $<327$ & 3.32 \\
\hline
\end{tabular}


Table D2-1. Sample-Based and Hanford Defined Waste-Based Inventory Estimates for Nonradioactive Components in Tank 241-BY-112. (2 sheets)

\begin{tabular}{|c|c|c|c|c|c|}
\hline linaligre & 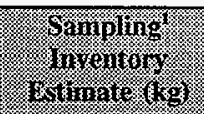 & 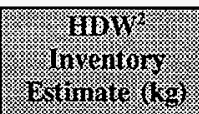 & montre & 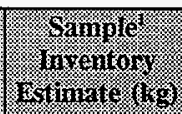 & 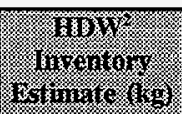 \\
\hline $\mathrm{NH}_{3}$ & NR & 359 & $\mathrm{H}_{2} \mathrm{O}(\mathrm{wt} \%)$ & 27.0 & 36.1 \\
\hline $\mathrm{Ni}$ & NR & 1,020 & $\begin{array}{l}\text { density } \\
(\mathrm{kg} / \mathrm{L})\end{array}$ & 1.46 & 1.63 \\
\hline $\mathrm{NO}_{2}$ & 37,000 & 83,700 & & & \\
\hline
\end{tabular}

Notes:

NR $=$ Not reported

${ }^{1}$ See Appendix B

${ }^{2}$ Agnew et al. (1997)

${ }^{3}$ Fluoride based on water soluble portion only

Table D2-2. Sample- and HDW Model-based Inventory Estimates for Radioactive Components in Tank 241-BY-112.

\begin{tabular}{|c|c|c|c|c|c|}
\hline Annigits: & 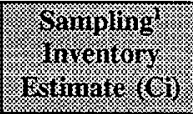 & 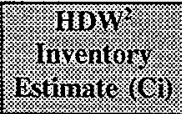 & Anatime & $\begin{array}{l}\text { Simming } \\
\text { Inventory } \\
\text { Gsimate (C) }\end{array}$ & 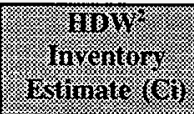 \\
\hline${ }^{90} \mathrm{Sr}$ & NR & 144,000 & ${ }^{2391240} \mathrm{Pu}$ & NR & 97.2 \\
\hline${ }^{137} \mathrm{Cs}$ & NR & 170,000 & & & \\
\hline
\end{tabular}

Notes:

'See Appendix B

${ }^{2}$ Agnew et al. (1997)

\section{D3.0 COMPONENT INVENTORY EVALUATION}

The following evaluation of tank contents is performed to identify potential errors and/or missing information that would influence the sample-based and HDW model component inventories. 


\section{D3.1 EXPECTED TYPE OF WASTE BASED ON THIS ASSESSMENT}

The reported waste types in tank 241-BY-112 are below. For a detailed summary of the waste transfer history, see Appendix B.

Agnew et al. (1997): MW, PFeCN, BYSltCk

Hill et al. (1995): TBP-F, EB-ITS, CW

Abbreviations:

PFeCN = Uranium recovery or tributyl phosphate supernatants that were

$\begin{array}{ll} & \text { ferrocyanide scavenged in U Plant } \\ \text { EB-ITS } \quad=\quad \text { Evaporator bottoms from in-tank solidification }\end{array}$

BYSltCk = BY saltcake (the same as EB-ITS in this case)

TBP-F = Tributyl phosphate-ferrocyanide scavenged uranium recovery (TBP) supernatants (equivalent to $\mathrm{PFeCN}$ )

$\mathrm{CW} \quad=\quad$ Cladding waste from the bismuth phosphate process

MW = Metal waste from the bismuth phosphate process

A sludge layer may exist at the bottom of tank 241-BY-112. During 1955, the tank was sluiced, and it was declared empty in July 1955 (Rodenhizer 1987). However, the HDW model assumes that not all metal waste were removed during the sluicing and attributes 7.6 $\mathrm{kL}$ ( $2 \mathrm{kgal})$ of the waste volume to metal waste sludge.

There is a possibility that $\mathrm{PFeCN}$ supernatants were transferred to the tank after it was sluiced, depositing some sludge in the tank (Agnew et al. 1995). Grigsby et al. (1992) strongly suggests a sludge layer exists in this tank. Because the sampling did not extend to the bottom of the tank, none of these assumptions can be verified. The sample-based inventory and the other portions of this TCR do not assume of sludge layer, therefore to be consistent this engineering assessment does not assume a sludge layer in tank 241-BY-112. The potential sludge layer is only a small portion of this tank's waste volume ( $<3$ percent). Only a new sample from the bottom of tank 241-BY-112 can indicate which assumption is correct.

Salt waste supernatants were evaporated and concentrated in the 1960s and 1970s using an in-tank heater (in-tank solidification unit) in tank 241-BY-112. A major portion of the waste in-tank 241-BY-112 consists of this BYSltCk. 


\section{D3.2 ASSUMPTIONS USED}

The sections below provide an engineering evaluation of tank 241-BY-112 contents. For this evaluation, the following assumptions and observations were made.

- Total waste mass is calculated using the sample-based measured density and the tank volume listed in (Hanlon 1997) (1,101 kL [291 kgal]). The waste types that contribute to the total volume are slightly different in each reference as described in Sections D2.0 and D3.1. As a result, the two inventory estimates are not made on the same waste type basis but vary by less than about 3 percent. The different densities provide approximately an additional 11 percent error basis.

- Only the BYSltCk waste stream contributed to solids formation.

- No radiolysis of $\mathrm{NO}_{3}$ to $\mathrm{NO}_{2}$ and no additions of $\mathrm{NO}_{2}$ to the waste for corrosion purposes are factored into this evaluation.

\section{D3.3 BASIS FOR CALCULATIONS USED IN THIS EVALUATION}

Table D3-1 summarizes the engineering evaluation approach used on tank 241-BY-112. 
Table D3-1. Assessment Methodology Used For Tank 241-BY-112.

\begin{tabular}{|l|l|l|}
\hline Supernatant & No supernatant was predicted. & n/a \\
\hline Saltcake & $\begin{array}{l}\text { Used the sample-based inventory, } \\
\text { calculated by multiplying the average } \\
\text { tank analyte concentration by the } \\
\text { total mass of waste in } \\
\text { tank } 241-\mathrm{BY}-112 . \text { The density used } \\
\text { was the average measured density } \\
(1.46 \mathrm{ggal})\end{array}$ & $\begin{array}{l}\text { The analyte concentrations for } \\
\text { several } 241-\mathrm{BY} \text { tanks } \\
\text { containing BYSltCk were } \\
\text { compared to tank 241-BY-112. }\end{array}$ \\
$\begin{array}{l}\text { The average sample-based } \\
\text { analyte concentrations for three } \\
241-\mathrm{BY} \text { tanks }(241-\mathrm{BY}-102, \\
241-\mathrm{BY}-111 \text { and } 241-\mathrm{BY}-112) \\
\text { were multiplied by saltcake } \\
\text { total mass in tank } 241-\mathrm{BY}-112 \\
\text { to predict the tank 241-BY-112 } \\
\text { inventory. The density used } \\
\text { was the density of } \\
\text { tank 241-BY-112 }(1.46 \mathrm{~g} / \mathrm{mL}) .\end{array}$ \\
\hline Sludge & No siudge was assumed. & n/a \\
\hline
\end{tabular}

BY saltcake denotes salt waste supernatants that were blended and concentrated using in-tank heaters. In-tank solidification campaigns were performed in the BY Tank Farm from 1964 through 1976. Waste supernatants, which were evaporated, originated primarily from the $\mathrm{BiPO}_{4}$ process operations in B Plant. Heaters were placed in tanks 241-BY-101, 241-BY-102, and 241-BY-112. The heater was in tank 241-BY-101 only for a short time. Certain BY tanks were designated as feed tanks. Concentrates from the heated tanks were transferred to other tanks in the BY Tank Farm and some BX Tank Farm tanks where they cooled and crystallized (Agnew et al. 1995).

Agnew et al. (1997) provide a defined waste composition for BY saltcake. Because of the complicated waste transfer history of the ITS campaign and the lack of a flowsheet basis for the waste composition, it is difficult to perform an independent assessment to estimate a saltcake composition that can be compared to the model-based BY saltcake composition.

However, samples from BY Tank Farm tanks, other than tank 241-BY-112, that contain BY saltcake have been analyzed, and the results have been reported. The analytical results for these tanks were evaluated at the core segment level, and BY saltcake was identified. Table D3-2 summarizes the compositions of saltcake from tanks 241-BY-105, 241-BY-106, and 241-BY-110 based on the segment-level analysis reported, respectively, in Simpson et al. (1996a), Bell et al. (1996), and Simpson et al. (1996b). For comparison, Table D3-2 also 
shows the waste component concentrations for tank 241-BY-102, 241-BY-112, and the saltcake defined waste composition from (Agnew et al. 1997).

As Table D3-2 indicates, the concentrations of major waste components such as sodium, aluminum, nitrate, fluoride, and sulfate vary among the three comparison tanks (tanks 241-BY-105, 241-BY-106, and 241-BY-110) by no more than a factor of about three. However, the variation among tanks for minor components is much higher.

The iron, chromium, nickel, silicon, fluoride, phosphate, and sulfate concentrations in samples from tanks 241-BY-102 and 241-BY-112 are much higher than the corresponding average concentrations of those components in the three BY Tank Farm comparison tanks. The high sulfate and phosphate concentrations in tanks 241-BY-102 and 241-BY-112 are apparently compensated by lower nitrate concentrations. Some apparent anomalies for tanks 241-BY-102 and 241-BY-112 probably result from using tanks 241-BY-102 and 241-BY-112 as ITS units. These tanks contained the heater, whereas several other BY Tank Farm tanks received previously cooled evaporated supernatant from tanks 241-BY-102 and/or 241-BY-112. In particular, components with lower solubilities would probably concentrate and precipitate from solution and collect on the cooler surfaces of the ITS unit in tanks $241-\mathrm{BY}-102$ or $241-\mathrm{BY}-112$.

For several analytes, the average analytical-based composition from tanks 241-BY-105, 241-BY-106, and 241-BY-110 compare more favorably with the HDW model saltcake composition than the composition of tanks 241-BY-102 or 241-BY-112. For others, the opposite is true. For this reason, the tanks listed in Table D3-3 were used in the engineering assessment to predict tank 241-BY-112 waste composition not these tanks. 


\begin{tabular}{|c|c|c|c|c|c|c|c|}
\hline $000^{\circ} \mathrm{s81}$ & $000^{\circ}+\varepsilon \varepsilon$ & $000^{\circ} \angle 9 z$ & $000^{\circ} \varepsilon I Z$ & $000^{\circ} \angle \varepsilon Z$ & $000^{\prime} \varepsilon 0 z$ & $000^{\circ} 86 \mathrm{I}$ & $\mathrm{e}_{\mathrm{N}}$ \\
\hline $0 Z \varepsilon^{\prime} I$ & OEt 2 & OSE $\varepsilon^{c} t$ & $z L Z$ & ISt & +81 & $08 \mathrm{I}$ & IS \\
\hline 956 & yN & $\mathrm{UN}$ & tOL'I & $0 \varepsilon 6^{6} \mathrm{I}$ & $0<t^{6} z$ & $z I L$ & $\mathrm{X}$ \\
\hline XN & $O L L^{6} L>$ & $\cos ^{4} 6>$ & IEZ'z & $0 S 9^{6} t$ & $Z \varepsilon 0^{\circ} \mathrm{I}$ & $010^{6} \mathrm{I}$ & d \\
\hline $866^{\circ} \mathcal{E}$ & $009^{\circ} 91$ & $000^{\circ} \mathrm{LZ}$ & 0218 & $00 z^{6}+I$ & $0 L Z^{\prime} s$ & $068^{6} t$ & 21eudsoud \\
\hline stio & $009^{\circ} 62$ & $00 \varepsilon^{\prime} 6 \mathrm{I}$ & $\angle 6 Z^{\prime} I I$ & $009^{6} \varepsilon I$ & $066^{\prime} 8$ & $00 \varepsilon^{6} I I$ & गाएгехо \\
\hline$t t I^{6} \angle t$ & $00 t^{\circ} 0 z$ & $006^{6} \varepsilon \mathrm{I}$ & $L E 0^{\prime} \triangleright Z$ & $009^{6} 0 \varepsilon$ & $00 I^{\prime} z \varepsilon$ & $0 \mathrm{It} 66$ & วฺ!!!ก \\
\hline $000^{6} 6+2$ & $00 t^{6} \varepsilon L$ & $000^{\circ} 56$ & $000^{\circ} \mathrm{SEE}$ & $000^{6}+8 \mathrm{I}$ & $000^{\circ} 62 \varepsilon$ & $000^{\prime} 16 t$ & วleI!IN \\
\hline$\angle 8 b$ & $\mathrm{ZN}$ & $0 z 8^{6} t$ & $90 \mathrm{I}$ & $\varepsilon 6 \mathrm{I}$ & $6 . \mathrm{Lt}$ & $6 . \mathrm{SL}$ & !N \\
\hline $60 \mathrm{I}$ & $z 6 z>$ & $\tau L E$ & $1.6 \varepsilon$ & 8.25 & $\angle S \cdot 6$ & $8^{\circ}+s$ & uw \\
\hline $\mathrm{I} Z L$ & $0+0^{\prime} r>$ & $0 \varepsilon 0^{6} Z>$ & 28 & $0 E I$ & $s+9$ & $\varepsilon 0 S$ & $\mathbf{q d}_{\mathbf{d}}$ \\
\hline $6+L$ & $096^{6} \mathrm{Z}$ & $098^{\prime} \mathrm{I}$ & $8 E S$ & +26 & sIZ & $9 \angle t$ & $\partial \underline{H}$ \\
\hline $6+9$ & $0 \mathrm{Lt}^{6} 6$ & $000^{\circ} 8 \mathrm{I}$ & $\varepsilon 88^{\circ} t$ & $0 \tau \nabla^{\circ} s$ & $0 \varepsilon I^{\prime} s$ & $00 I^{\prime} t$ & әpبัon[u \\
\hline$\nabla S L^{6} I$ & $00 S^{6} \angle I$ & $0 \angle 8^{\circ} \mathrm{I}$ & $6 S \varepsilon^{\prime} I$ & $006^{6} \mathrm{z}$ & SS8 & $I Z \varepsilon$ & Iว \\
\hline $098^{\circ} \mathrm{Z}$ & OSI $I^{6} \mathrm{I}$ & $0 z Z^{\circ} \mathrm{I}$ & $9 \varepsilon L^{\prime} \mathrm{I}$ & $0 S z^{\prime} Z$ & $090^{\circ} \mathrm{Z}$ & $\angle 68$ & әрџџочน \\
\hline $\mathrm{I} 6 L^{6} \mathrm{I}$ & $0+0^{\circ} \mathrm{z}>$ & $00 I^{\prime} \mathrm{Z}>$ & $80 \varepsilon$ & $00 t$ & $80 \varepsilon$ & 912 & ED \\
\hline $6+t I I$ & $0+0^{6} z>$ & $0 \varepsilon 0^{\prime} z>$ & $9^{\circ} \mathrm{ss}$ & $\mathrm{YN}$ & $\mathrm{UN}$ & $9^{\circ} \mathrm{SS}$ & !g \\
\hline$\nabla \angle 6^{\prime} \dagger \varepsilon$ & $00 Z^{\prime} 8 \mathrm{I}$ & $009^{\circ} 10$ & $\varepsilon \varepsilon 9^{6} \angle I$ & $00 I^{\prime}+I$ & $00 t^{\circ} 0 z$ & $00 t^{6} 8 \mathrm{I}$ & IV \\
\hline 4 & & & 3 & & Sinon & rodrio o - oryul & Hogpsw10\% \\
\hline 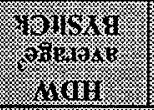 & 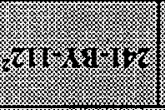 & 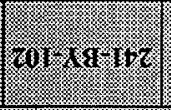 & 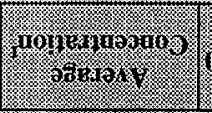 & 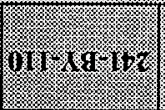 & 901 & 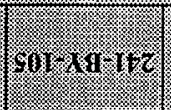 & 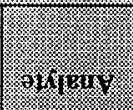 \\
\hline
\end{tabular}

(stoous $\tau$ )

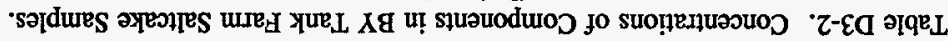


Table D3-2. Concentrations of Components in BY Tank Farm Saltcake Samples: (2 sheets)

\begin{tabular}{|c|c|c|c|c|c|c|c|}
\hline & $\sqrt{7}$ & & cermpo & 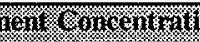 & (3) $(k 9 / 6)$ & & \\
\hline Amaige: & $241 . \mathrm{BI} / \mathrm{ing}$ & $(24) \cdot 11.106$ & $2.11 . \mathrm{Br}-11$ & 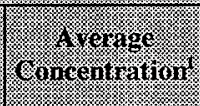 & $241.3 \%$ & $(2.18 .31 \% .19$ & 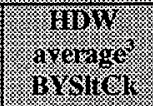 \\
\hline $\mathrm{Sr}$ & 88.3 & 44.4 & 58.1 & 64 & $<203$ & $<204$ & 0 \\
\hline Sulfate & 10,600 & 11,300 & 18,400 & 13,433 & 57,700 & 25,000 & 11,373 \\
\hline $\mathbf{S}$ & 3,140 & 3 & 5,950 & 4,123 & 17,300 & 9,800 & NR \\
\hline TIC & NR & 7,359 & 31,800 & 19,580 & 27,800 & 40,700 & 3,718 \\
\hline TOC & 3,250 & 2,500 & 5,920 & 3,890 & 4,360 & 8,510 & NR \\
\hline $\bar{U}$ & 261 & 164.2 & 697 & 374 & $<10,100$ & $<10,200$ & 3,930 \\
\hline $\mathrm{Zn}$ & 36.8 & 164.2 & 32.8 & 77.9 & $<396$ & $<223$ & NR \\
\hline $\mathrm{Zr}$ & 5.23 & 6.28 & $\longdiv { 1 4 . 4 }$ & 8.64 & $<203$ & $<204$ & 1.9 \\
\hline $\begin{array}{l}\text { Density } \\
(\mathrm{g} / \mathrm{mL})\end{array}$ & NR & 1.71 & NR & 1.71 & 1.50 & 1.46 & 1.63 \\
\hline $\mathrm{wt} \% \mathrm{H}_{2} \mathrm{O}$ & 16.1 & 25.5 & 23.2 & 21.6 & NR & 27.0 & 36.1 \\
\hline Aarilanum & (1) Tes: & $: 8$ & & & & & \\
\hline${ }^{90} \mathrm{Sr}$ & NR & $<4.26$ & 22.5 & 22.5 & $\mathrm{NR}$ & NR & 78 \\
\hline${ }^{137} \mathrm{Cs}$ & $\overline{\mathrm{NR}}$ & 106 & 60 & 83 & NR & NR & 92.2 \\
\hline $2391240 \mathrm{Pu}$ & $\overline{N R}$ & NR & 0.0192 & 0.0192 & $\mathbf{N R}$ & NR & 0.056 \\
\hline
\end{tabular}

Notes:

'Average analyte concentrations for tank 241-BY-105, 241-BY-106, and 241-BY-110

${ }^{2}$ From Appendix B

${ }^{3}$ Agnew et al. (1997). 
In Table D3-2, component concentrations in tank 241-BY-112 appear more like those for tank 241-BY-102 than those in other BY Tank Farm tanks. It was not expected that component concentrations for tank 241-BY-111, which did not have an ITS unit, are more closely aligned to BY Tank Farm tanks with an ITS unit. Therefore, the engineering assessment compares tank 241-BY-112 concentrations to the concentrations of tank 241-BY102, an ITS tank, to tank 241-BY-111 (see Table D3-3).

The engineering assessment inventories for tank 241-BY-112 were determined by multiplying the average concentration of the three tanks by 291 (kgal), 3,785 (kgal to L), and 1.46 (the density in $\mathrm{g} / \mathrm{mL}$ ) and then dividing by $1,000,000$ (to convert to $\mathrm{kg}$ ) (see Table D3-3).

Table D3-3. Tank 241-BY-112 Inventory Calculations. (2 sheets)

\begin{tabular}{|c|c|c|c|c|c|}
\hline 4 & $1.9 \mathrm{gs}$ & 19.95: & 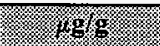 & 1898 & 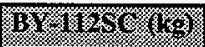 \\
\hline Henient & 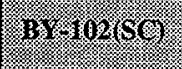 & $18 \times 1 / 119(89)$ & 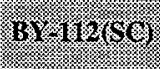 & 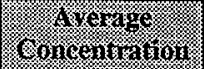 & 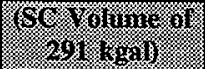 \\
\hline $\mathrm{Al}$ & 41,600 & 25,000 & 18,200 & 28,267 & 45,500 \\
\hline $\mathrm{Bi}$ & $<2,030$ & $<1,930$ & $<2,040$ & $<2,000$ & $<3,240$ \\
\hline $\mathrm{Ca}$ & $<2,100$ & $<4,180$ & $<2,040$ & $<2,774$ & $<4,490$ \\
\hline Chloride & 1,220 & 1,090 & 1,150 & 1,153 & 1,860 \\
\hline $\mathrm{Cr}$ & 1,870 & 2,060 & 17,500 & 7,143 & 11,500 \\
\hline Fluoride & 18,000 & 9,620 & 9,410 & 12,343 & 19,800 \\
\hline $\mathrm{Fe}$ & 1,860 & 5,960 & 2,960 & 3,593 & 5,780 \\
\hline $\mathrm{Pb}$ & $<2,030$ & $<1,930$ & $<2,040$ & $<2,000$ & $<3,240$ \\
\hline $\mathrm{Mn}$ & 372 & $<246$ & $<292$ & 372 & 598 \\
\hline $\mathrm{Ni}$ & 4,820 & NR & NR & 4,820 & 7,750 \\
\hline $\mathrm{NO}_{3}$ & 95,000 & 153,000 & 73,400 & 107,133 & 172,000 \\
\hline $\mathrm{NO}_{2}$ & 13,900 & 14,200 & 20,400 & 16,167 & 26,000 \\
\hline Oxalate & 19,300 & 19,300 & 29,600 & 22,733 & 36,600 \\
\hline $\mathrm{PO}_{4}$ & 27,000 & 20,000 & 16,600 & 21,200 & 34,100 \\
\hline $\mathbf{P}$ & $<9,500$ & 9,810 & $<7,770$ & 9,810 & 15,800 \\
\hline $\bar{K}$ & NR & NR & NR & NR & NR \\
\hline $\mathrm{Si}$ & 4,350 & 34,500 & 2,430 & 13,760 & 22,100 \\
\hline $\mathrm{Na}$ & 267,000 & 241,000 & 334,000 & 280,667 & 451,000 \\
\hline $\mathbf{S r}$ & $<203$ & $<205$ & $<204$ & $<204$ & $<330$ \\
\hline $\mathrm{SO}_{4}$ & 57,700 & 34,400 & 25,000 & 39,033 & 62,800 \\
\hline
\end{tabular}




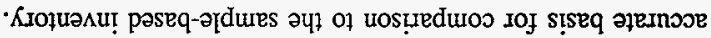

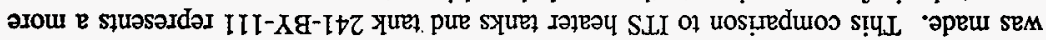

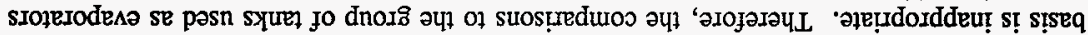

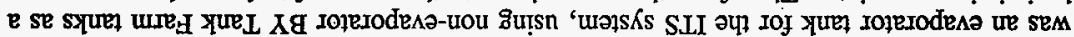

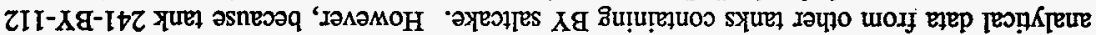

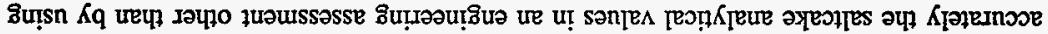

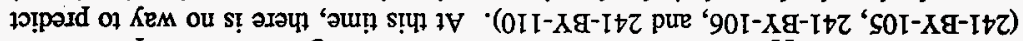

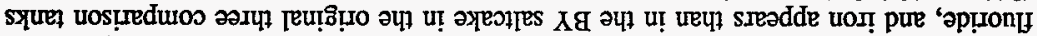

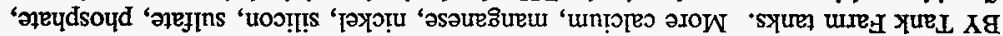

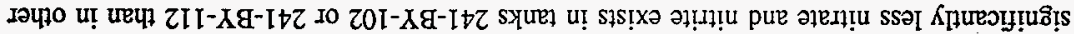

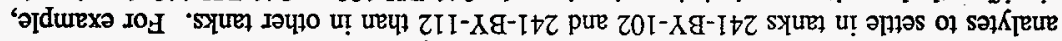

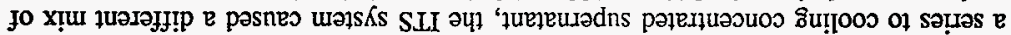

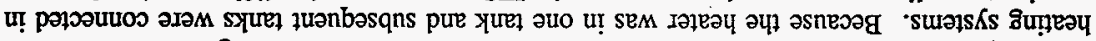

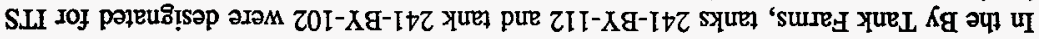

-suop̣earosqo

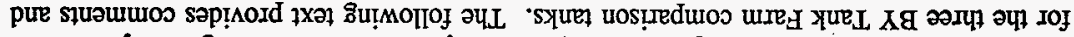

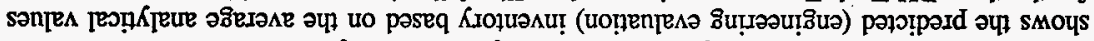

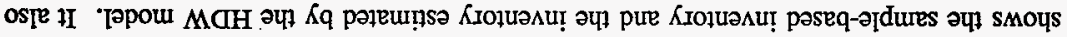

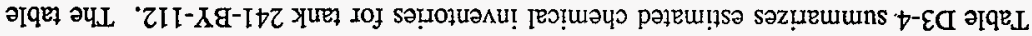

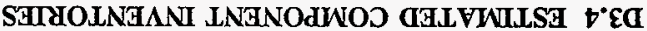

\begin{tabular}{|c|c|c|c|c|c|}
\hline & & & & \multicolumn{2}{|c|}{ 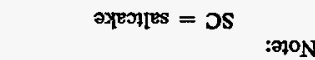 } \\
\hline XN & ZN & $\mathrm{BN}$ & ZN & $\mathbf{Z N}$ & $\mathrm{n}_{\mathrm{d}_{0 \times 2 / 662}}$ \\
\hline $\mathrm{YN}$ & YN & $\mathrm{ZN}$ & $\mathrm{XN}$ & UN & $\mathrm{sD}_{\mathrm{LE \textrm {I }}}$ \\
\hline $\mathbf{~} \mathrm{N}$ & en & $\mathrm{UN}$ & UN & $\mathrm{UN}$ & ${ }^{1} S_{06}$ \\
\hline (1) & 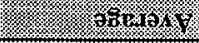 & 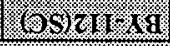 & $(r)=11 \% 18$ & (bs) col $\mathrm{xg}$ & (3) \\
\hline$\sqrt{4}$ & & 4. & (4) & 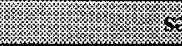 & 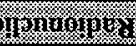 \\
\hline $8 z \varepsilon>$ & $\varepsilon 0 Z>$ & $t 0 \tau>$ & I0z> & $\varepsilon 0 z>$ & $I_{Z}$ \\
\hline $00 I^{\circ} 9 I>$ & $t \$ 6^{\circ} 6>$ & $00 z^{6} 0 I>$ & $099^{6} 6>$ & $000^{\circ} \mathrm{OI}>$ & $\Omega$ \\
\hline $009^{\circ} 0 \mathrm{I}$ & $0+9^{\circ} \mathrm{s}$ & $0 I S^{\prime} 8$ & $026^{\circ} 9$ & $09 \varepsilon^{c} t$ & DOL \\
\hline $00 \varepsilon^{6} 6 t$ & $00 L^{\prime} 0 \varepsilon$ & $00 L^{\prime} 0 t$ & $009^{\circ} \varepsilon z$ & $008^{\circ} \angle Z$ & OII \\
\hline $006^{6} 0 z$ & $\angle 96^{\circ} \mathrm{ZI}$ & $008^{\prime} 6$ & $008^{6} \mathrm{II}$ & $00 \varepsilon^{6} L I$ & $\mathrm{~S}$ \\
\hline voring $16 \%$ & 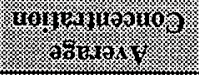 & $(35) \div 1=10$ & $(85111108$ & (2)sizol to & inamo, \\
\hline 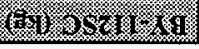 & - & 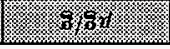 & (3) & (6) & 4 \\
\hline
\end{tabular}

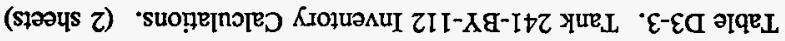


Table D3-4. Comparison of Selected Component Inventory Estimates for Tank 241-BY-112 Waste.

\begin{tabular}{|c|c|c|c|}
\hline (6) & 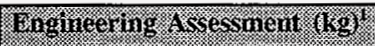 & 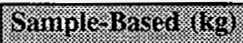 & 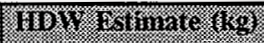 \\
\hline $\mathrm{Al}$ & 45,500 & 31,000 & 61,100 \\
\hline$\overline{\mathrm{Bi}}$ & $<3,240$ & $<3,270$ & 1,550 \\
\hline $\mathrm{Ca}$ & $<4,490$ & $<3,270$ & 3,430 \\
\hline $\mathrm{Cl}$ & 1,860 & 2,110 & 5,030 \\
\hline$\overline{\mathrm{Cr}}$ & 11,500 & 28,400 & 3,070 \\
\hline $\mathbf{F}$ & 19,800 & 15,100 & 1,180 \\
\hline $\mathrm{Fe}$ & 5,780 & 4,760 & 2,570 \\
\hline $\bar{K}$ & 2,740 & NR & 1,680 \\
\hline $\mathrm{La}$ & $<1,640$ & $<1,640$ & 0.304 \\
\hline $\mathbf{M n}$ & 598 & $<469$ & 191 \\
\hline $\mathrm{Na}$ & 451,000 & 543,000 & 330,000 \\
\hline $\mathrm{Ni}$ & 7,750 & NR & 1,020 \\
\hline $\mathrm{NO}_{3}$ & 172,000 & 124,000 & 450,000 \\
\hline $\mathrm{NO}_{2}$ & 26,000 & 37,000 & 83,700 \\
\hline Oxalate & 36,600 & 47,700 & 0.253 \\
\hline $\mathrm{Pb}$ & $<3,240$ & $<3,270$ & 1,260 \\
\hline $\mathrm{PO}_{4}$ & 34,100 & 26,700 & 8,030 \\
\hline $\mathrm{Si}$ & 22,100 & 3,910 & 2,350 \\
\hline $\mathrm{SO}_{4}$ & 62,800 & 40,400 & 20,100 \\
\hline Sr & $<330$ & $<327$ & 0 \\
\hline TIC & 49,300 & 65,300 & 6,740 \\
\hline TOC & 10,600 & 13,700 & 7,920 \\
\hline $\mathrm{U}$ & $<16,100$ & $<16,500$ & 10,000 \\
\hline $\mathrm{Zr}$ & $<328$ & $<327$ & 3.32 \\
\hline $\mathrm{H}_{2} \mathrm{O}$ (percent) & 29.5 & 27.0 & 36.1 \\
\hline
\end{tabular}

Note:

${ }^{1}$ Based on average concentrations for components in tanks 241-BY-102, 241-BY-111, and 241-BY-112. 
The HDW model does not represent the decreased solubilities for components in tank 241-BY-112 (for example, chromium, phosphate, sulfate, and fluoride) that are normally soluble in other non-ITS evaporator tanks containing BY saltcake. The increased temperatures and rapid boil-off in tank $241-\mathrm{BY}-112$ probably resulted in concentration and precipitation of these components. These are very complicated multiphasic, multicomponent solution equilibria. The concentrated supernatants were transferred to other BY farm tanks for cooling and further precipitation of the more soluble components.

Because tank 241-BY-112 was an ITS evaporator tank, it is judged that the analytical data from the 1996 core sample best represents the component concentrations for this tank. With the exception of tank 241-BY-102, other tanks in the BY farm received concentrated supernatants from the ITS evaporator tanks. The waste in these receiver tanks exhibit markedly different concentrations of certain components. Tank 241-BY-111 received numerous direct transfers from tank $241-\mathrm{BY}-112$ and appears to be an exception.

Tank 241-BY-112 has an unusually high concentration of $\mathrm{Cr}$, and tank 241-BY-111 has an unusually high concentration of $\mathrm{Si}$. There is no apparent explanation from process history for these discrepancies. When the concentrations for these components and those of tank 241-BY-102 are averaged, the predicted inventories are not as accurate. This results in an apparent significant under prediction of $\mathrm{Cr}$ and a significant over prediction of Si in tank 241-BY-112 in the engineering assessment inventory.

Radionuclides were not measured in tanks 241-BY-102, 241-BY-111 or 241-BY-112. The best basis radionuclide values were engineering assessment values based on the heat load of tank 241-BY-111 from (Kummerer 1995), (Grigsby et al. 1992) or HDW values.

\section{D4.0 DEFINE THE BEST-BASIS AND ESTABLISH COMPONENT INVENTORIES}

Information about chemical, radiological, and/or physical properties is used to perform safety analyses, engineering evaluations, and risk assessment associated with waste management activities, as well as regulatory issues. These activities include overseeing tank farm operations and identifying, monitoring, and resolving safety issues associated with these operations and with the tank wastes. Disposal activities involve designing equipment, processes, and facilities for retrieving wastes and processing them into a form suitable for long-term storage.

Chemical and radiological inventory information are generally derived using three approaches: 1) component inventories are estimated using results of sample analyses, 2) component inventories are estimated using the HDW model based on process knowledge and historical information, or 3) a tank-specific process estimate is made based on process flowsheets, reactor fuel data, essential material usage, and other operating data. The information derived from these different approaches is often inconsistent. 
An effort is underway to provide waste inventory estimates that will serve as standard characterization source terms for waste management activities (Hodgson and LeClair 1996). As part of this effort, an evaluation of available chemical information for tank 241-BY-112 was performed, including the following:

- Data from recent analyses of two push-mode core samples collected in October 1996 (see Appendix B)

- An inventory estimate generated by the HDW model (Agnew et al. 1997)

- Evaluation of BY saltcake data using other BY Tank Farm tanks as a basis.

Based on this evaluation, a best-basis inventory was developed for tank 241-BY-112. For the following reasons, the sample-based inventory was chosen as the best basis for those analytes for which sample-based analytical values were available.

- The sample-based inventory analytical concentrations compared favorably to those of other BY evaporator tanks or the direct outsource tanks.

- No methodology is available to fully predict BY saltcake from process flowsheet or historical records.

- Waste transfer records are not complete and not always accurate.

For those few analytes for which no values could be calculated from the sample-based inventory, the engineering evaluation data or the HDW model values were used. These estimates are less reliable than the values for which sample data are available.

Based on this evaluation, a best-basis inventory was developed for tank 241-BY-112. . When the sample-based inventory had a high less-than value or was not measured, the engineering assessment-based values were used (if applicable). Some high less than values are reported because the three tanks used in the engineering assessment had high less than values. Results for radionuclides were not available for the sample-based inventory. The best basis radionuclide values were engineering assessment values based on the heat load of tank 241-BY-112 from Kummerer (1995) or HDW values. The HDW model was used only where no other data were available. Tables D4-1 and D4-2 show the best-basis inventory for tank 241-BY-112.

Once the best-basis inventories were determined, the hydroxide inventory was calculated by performing a charge balance with the valences of other analytes. In some cases, this approach requires that other analyte (for example, sodium or nitrate) inventories be adjusted to achieve the charge balance. During such adjustments, the number of significant figures is not increased. This charge balance approach is consistent with that used by Agnew et al. (1997). 
The inventory values reported in Tables D4-1 and D4-2 are subject to change. Refer to the Tank Characterization Database for the most current inventory values.

Best-basis tank inventory values are derived for 46 key radionuclides (Kupfer et al. 1997), all decayed to a common report date of January 1, 1994. Often, waste sample analyses have reported only ${ }^{90} \mathrm{Sr},{ }^{137} \mathrm{Cs},{ }^{239 / 240} \mathrm{Pu}$, and total uranium (or total beta and total alpha), while other key radionuclides such as ${ }^{60} \mathrm{Co},{ }^{99} \mathrm{Tc},{ }^{129} \mathrm{I},{ }^{154} \mathrm{Eu},{ }^{155} \mathrm{Eu}$, and ${ }^{241} \mathrm{Am}$ have been reported infrequently. For this reason, it has been necessary to derive most of the 46 key radionuclides by computer models. These models estimate radionuclide activity in batches of reactor fuel, account for the split of radionuclides to separations plant waste streams, and track their movement with tank waste transactions. (These computer models are described in Kupfer et al. 1997 and in Watrous and Wootan 1997.) Model generated values for radionuclides in any of 177 tanks are reported in Agnew et al. (1997). The best-basis value for any one analyte may be a model result or a sample or engineering assessment-based result if available. (No attempt has been made to ratio or normalize model results for the 46 radionuclides when values for measured radionuclides disagree with the model.) For a discussion of typical error between model derived values and sample derived values, see Kupfer et al. (1997). 
Table D4-1. Best-Basis Inventory Estimates for Nonradioactive Components in Tank 241-BY-112 (Effective May 31, 1997). (2 sheets)

\begin{tabular}{|c|c|c|c|}
\hline 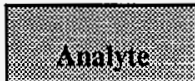 & 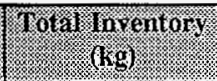 & 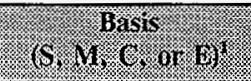 & (20) \\
\hline Al & 31,000 & $\mathrm{~S}$ & -- \\
\hline $\mathrm{Bi}$ & $<3,270$ & $S$ & -- \\
\hline $\mathrm{Ca}$ & $<3,270$ & $S$ & $-\cdots$ \\
\hline $\mathrm{Cl}$ & 2,110 & $S$ & -- \\
\hline TIC as $\mathrm{CO}_{3}$ & 326,000 & $S$ & - \\
\hline $\mathrm{Cr}$ & 28,400 & $S$ & High throughout $\operatorname{tank}$ \\
\hline $\mathbf{F}$ & 15,100 & $S$ & - \\
\hline $\mathrm{Fe}$ & 4,760 & $S$ & -- \\
\hline $\mathrm{Hg}$ & 7.79 & $M$ & -- \\
\hline$\overline{\mathbf{K}}$ & 2,740 & $\bar{E}$ & $\begin{array}{l}\text { Used average concentration from } \\
\text { other tanks in BY Farm }\end{array}$ \\
\hline $\mathbf{L a}$ & 0.304 & $\bar{M}$ & -- \\
\hline $\mathrm{Mn}$ & $<469$ & $S$ & - \\
\hline$\widehat{\mathrm{Na}}$ & 543,000 & $S$ & - \\
\hline $\mathrm{Ni}$ & 7,750 & $\mathrm{E}$ & $\begin{array}{l}\text { Used average concentration from } \\
\text { other tanks in BY Farm. May be } \\
\text { too high as no actual data for ITS } \\
\text { tanks. }\end{array}$ \\
\hline $\mathrm{NO}_{2}$ & 37,000 & $\mathrm{~S}$ & -- \\
\hline $\mathrm{NO}_{3}$ & 124,000 & $S$ & -- \\
\hline $\mathrm{OH}_{\text {TOTAL }}$ & 209,000 & $\mathrm{C}$ & Calculated from charge balance \\
\hline$\overline{\mathrm{Pb}}$ & $<3,270$ & $S$ & -- \\
\hline $\mathrm{PO}_{4}$ & 26,700 & $S$ & -- \\
\hline$\widehat{\mathrm{Si}}$ & 3,910 & $S$ & -- \\
\hline $\mathrm{SO}_{4}$ & 40,400 & $S$ & -- \\
\hline $\mathrm{Sr}$ & $<327$ & $S$ & -- \\
\hline
\end{tabular}


Table D4-1. Best-Basis Inventory Estimates for Nonradioactive Components in Tank 241-BY-112 (Effective May 31, 1997). (2 sheets)

\begin{tabular}{|c|c|c|c|}
\hline 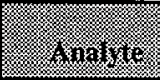 & Tofal ingenting & 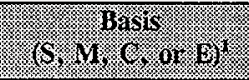 & 60011010 \\
\hline TOC & 13,600 & S & -- \\
\hline $\mathrm{U}_{\text {TOTAL }}$ & $<16,500$ & $S$ & -- \\
\hline $\mathrm{Zr}$ & $<327$ & $S$ & - \\
\hline
\end{tabular}

Note:

${ }^{1} \mathrm{~S}=$ sample-based, $\mathrm{M}=\mathrm{HDW}$-model based, $\mathrm{E}=$ engineering-based,

$\mathrm{C}=$ calculated by charge balance; includes oxides as hydroxides not including $\mathrm{CO}_{3}, \mathrm{NO}_{3}, \mathrm{NO}_{2}, \mathrm{PO}_{4}$, $\mathrm{SO}_{4}$, and $\mathrm{SiO}_{3}$ 
HNF-SD-WM-ER-701 Rev. 0

Table D4-2. Best-Basis Inventory Estimates for Radioactive Components in

Tank 241-BY-112 Decayed to January 1, 1994. (Effective May 31, 1997) (2 sheets)

\begin{tabular}{|c|c|c|c|}
\hline$\frac{\sqrt{7}}{4}$ & $\begin{array}{l}\text { Troul } \\
\text { Imentor) } \\
\text { (cil) }\end{array}$ & 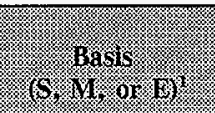 & t) \\
\hline${ }^{3} \mathrm{H}$ & 140 & $\mathrm{M}$ & \\
\hline${ }^{14} \mathrm{C}$ & 36.4 & $\mathbf{M}$ & \\
\hline${ }^{59} \mathrm{Ni}$ & 3.97 & $\mathrm{M}$ & \\
\hline${ }^{60} \mathrm{Co}$ & 34.1 & $\mathrm{M}$ & \\
\hline${ }^{63} \mathrm{Ni}$ & 394 & $\mathbf{M}$ & \\
\hline${ }^{79} \mathrm{Se}$ & 3.06 & $\mathbf{M}$ & \\
\hline${ }^{90} \mathrm{Sr}$ & 133,000 & $\mathrm{E}$ & HDW estimate was 144,000 \\
\hline${ }^{90} \mathrm{Y}$ & 133,000 & $\mathrm{E}$ & Based on ${ }^{90} \mathrm{Sr}$ \\
\hline${ }^{93} \mathbf{Z r}$ & 14.7 & $\mathbf{M}$ & \\
\hline${ }^{93 \mathrm{~m}} \mathrm{Nb}$ & 10.7 & $\mathbf{M}$ & \\
\hline${ }^{99} \mathrm{Tc}$ & 203 & $\mathrm{M}$ & \\
\hline${ }^{106} \mathrm{Ru}$ & 0.00680 & $\mathbf{M}$ & \\
\hline${ }^{113 m} \mathrm{Cd}$ & 78.1 & $\mathrm{M}$ & \\
\hline${ }^{125} \mathrm{Sb}$ & 153 & $\mathrm{M}$ & \\
\hline${ }^{126} \mathrm{Sn}$ & 4.57 & $\bar{M}$ & \\
\hline${ }^{129} \mathbf{T}$ & 0.393 & M & \\
\hline${ }^{134} \mathrm{Cs}$ & 1.66 & $\mathrm{M}$ & \\
\hline${ }^{137} \mathrm{Cs}$ & 189,000 & $\mathrm{E}$ & HDW estimate was 170,000 \\
\hline${ }^{137 m} \mathrm{Ba}$ & 179,000 & $\mathrm{E}$ & From ${ }^{137} \mathrm{Cs}$ \\
\hline${ }^{151} \mathrm{Sm}$ & 10,600 & $\mathbf{M}$ & \\
\hline${ }^{152} \mathrm{Eu}$ & 4.81 & M & \\
\hline${ }^{154} \mathrm{Eu}$ & 575 & $\mathbf{M}$ & \\
\hline${ }^{155} \mathrm{Eu}$ & 291 & $\mathrm{M}$ & \\
\hline${ }^{226} \mathrm{Ra}$ & $1.48 \mathrm{E}-04$ & $\mathbf{M}$ & \\
\hline${ }^{227} \mathrm{Ac}$ & 0.00208 & $\mathbf{M}$ & \\
\hline${ }^{228} \mathrm{Ra}$ & 1.82 & M & \\
\hline${ }^{229} \mathrm{Th}$ & 0.0420 & M & \\
\hline${ }^{231} \mathrm{~Pa}$ & 0.0107 & M & \\
\hline${ }^{232} \mathrm{Th}$ & 0.0673 & M & \\
\hline
\end{tabular}


Table D4-2. Best-Basis Inventory Estimates for Radioactive Components in

Tank 241-BY-112 Decayed to January 1, 1994. (Effective May 31, 1997) (2 sheets)

\begin{tabular}{|c|c|c|c|}
\hline A.milyter & $\begin{array}{l}\text { Total } \\
\text { inventor) } \\
\text { (et) }\end{array}$ & (S. Misis. or: Lf & Comnent \\
\hline${ }^{232} \mathrm{U}$ & 10.2 & $\mathrm{M}$ & \\
\hline $233 \mathrm{U}$ & 38.9 & $\mathrm{M}$ & \\
\hline${ }^{234} \mathrm{U}$ & 3.79 & $\mathbf{M}$ & \\
\hline${ }^{235} \mathrm{U}$ & 0.149 & $\bar{M}$ & \\
\hline${ }^{236} \mathrm{U}$ & 0.0983 & $\mathrm{M}$ & \\
\hline${ }^{237} \mathrm{~Np}$ & 0.680 & $\bar{M}$ & \\
\hline${ }^{238} \mathrm{Pu}$ & 2.71 & $\bar{M}$ & \\
\hline${ }^{238} \mathrm{U}$ & 6.82 & $\bar{M}$ & \\
\hline${ }^{239} \mathrm{Pu}$ & 97.2 & $\mathrm{M}$ & \\
\hline${ }^{240} \mathrm{Pu}$ & 16.7 & $\mathrm{M}$ & \\
\hline${ }^{241} \mathrm{Am}$ & 47.7 & $\mathrm{M}$ & \\
\hline${ }^{241} \mathrm{Pu}$ & 196 & $\mathbf{M}$ & \\
\hline${ }^{242} \mathrm{Cm}$ & $8.81 \mathrm{E}-04$ & $\mathrm{M}$ & \\
\hline${ }^{242} \mathrm{Pu}$ & $9.42 \mathrm{E}-04$ & $\bar{M}$ & \\
\hline${ }^{243} \mathrm{Am}$ & 0.00165 & $\mathrm{M}$ & \\
\hline${ }^{243} \mathrm{Cm}$ & $1.80 \mathrm{E}-05$ & $\mathrm{M}$ & \\
\hline${ }^{244} \mathrm{Cm}$ & $2.21 E-04$ & $\mathrm{M}$ & \\
\hline
\end{tabular}

Notes:

${ }^{1} \mathbf{S}=$ sample-based, $\mathbf{M}=$ HDW-model based, $\mathbf{E}=$ engineering-based,

$\mathrm{C}=$ calculated by charge balance; includes oxides as hydroxides not including $\mathrm{CO}_{3}$, $\mathrm{NO}_{3}, \mathrm{NO}_{2}, \mathrm{PO}_{4}, \mathrm{SO}_{4}$, and $\mathrm{SiO}_{3}$ 


\section{D5.0 APPENDIX D REFERENCES}

Agnew, S. F., R. A. Corbin, T. B. Duran, K. A. Jurgensen, T. P. Ortiz, and B. L. Young, 1995, Waste Status and Transaction Record Summary, WSTRS, Rev. 2, WHC-SD-WM-TI-615, -614, -669, -689, Rev. 2, Los Alamos National Laboratory, Los Alamos, New Mexico.

Agnew, S. F., J. Boyer, R. A. Corbin, T. B. Duran, J. R. FitzPatrick, K. A. Jurgensen, T. P. Ortiz, and B. L. Young, 1997, Hanford Tank Chemical and Radionuclide Inventories: HDW Model Rev. 4, LA-UR-96-3860, Rev. 4, Los Alamos National Laboratory, Los Alamos, New Mexico.

Bell, K. E., J. Franklin, J. Stroup, and J. L. Huckaby, 1996, Tank Characterization Report for Single-Shell Tank 24l-BY-106, WHC-SD-WM-ER-616, Rev. 0, Westinghouse Hanford Company, Richland, Washington.

Grigsby, J. M., D. B. Bechtold, G. L. Borsheim, M. D. Crippen, D. R. Dickinson, G. L. Fox, D. W. Jeppson, M. Kummerer, J. M. McLaren, J. D. McCormack, A. Padilla, B. C. Simpson, and D. D. Stepnewski, 1992, Ferrocyanide Waste Tank Hazard Assessment--Interim Report, WHC-SD-WM-RPT-032, Rev. 1, Westinghouse Hanford Company, Richland, Washington.

Hanlon, B. M., 1997, Waste Tank Summary Report for Month Ending January 31, 1997, HNF-EP-0182-106, Lockheed Martin Hanford Corp. for Fluor Daniel Hanford, Inc., Richland, Washington.

Hill, J. G., G. S. Anderson, and B. C. Simpson, 1995, The Sort on Radioactive Waste Type Model: A Method to Sort Single-shell Tanks into Characteristic Groups, PNL-9814, Rev. 2, Pacific Northwest Laboratory, Richland, Washington.

Hodgson, K. M., and M. D. LeClair, 1996, Work Plan for Defining a Standard Inventory Estimate for Wastes Stored in Hanford Site Underground Tanks, WHC-SD-WM-WP-311, Rev. 1, Lockheed Martin Hanford Corp. for Fluor Daniel Hanford, Inc., Richland, Washington.

Kummerer, M., 1995, Heat Removal Characteristics of Waste Storage Tanks, WHC-SD-WM-SARR-010, Rev. 1, Westinghouse Hanford Company, Richland, Washington. 
Kupfer, M. J., A. L. Boldt, B. A. Higley, K. M. Hodgson, L. W. Shelton, R. A. Watrous, S. L. Lambert, D. E. Place, R. M. Orme, G. L. Borsheim, N. G. Colton, M. D. LeClair, R. T. Winward, and W. W. Schulz, 1997, Standard Inventories of Chemicals and Radionuclides in Hanford Site Tank Wastes, HNF-SD-WM-TI-740, Rev. 0, Lockheed Martin Hanford Corp. for Fluor Daniel Hanford, Inc., Richland, Washington.

Rodenhizer, D. G., 1987, Hanford Waste Tank Sluicing History, WHC-SD-WM-TI-302, Rev. 0, Westinghouse Hanford Company, Richland, Washington.

Simpson, B. C., J. G. Field, and L. M. Sasaki, 1996a, Tank Characterization Report for Single-Shell Tank 241-BY-105, WHC-SD-WM-ER-598, Rev. 0, Westinghouse Hanford Company, Richland, Washington.

Simpson, B. C., R. D. Cromar, R. D. Schreiber, 1996b, Tank Characterization Report for Single-Shell Tank 241-BY-110, WHC-SD-WM-ER-591, Rev. 0, Westinghouse Hanford Company, Richland, Washington.

Watrous, R. A. and D. W. Wootan, 1997, Activity of Fuel Batches Processed Through Hanford Separations Plants, 1944 Through 1989, HNF-SD-WM-TI-794, Rev. 0, Lockheed Martin Hanford Corp. for Fluor Daniel Hanford, Inc., Richland, Washington. 
HNF-SD-WM-ER-701 Rev. 0

This page intentionally left blank. 
HNF-SD-WM-ER-701 Rev. 0

APPENDIX E

BIBLIOGRAPHY FOR TANK 241-BY-112

E-1 
HNF-SD-WM-ER-701 Rev. 0

This page intentionally left blank. 


\section{APPENDIX E \\ BIBLIOGRAPEY FOR TANK 241-BY-112}

Appendix $\mathrm{E}$ is a bibliography of information that supports the characterization of tank 241-BY-112. This bibliography represents an in-depth literature search of all known information sources that provide sampling, analysis, surveillance, and modeling information, as well as processing occurrences associated with tank 241-BY-112 and its respective waste types.

The references in this bibliography are separated into three broad categories containing references broken down into subgroups. These categories and their subgroups are listed below.

\section{NON-ANALYTICAL DATA}

Ia. Models/Waste Type Inventories/Campaign Information

Ib. Fill History/Waste Transfer Records

Ic. Surveillance/Tank Configuration

Id. Sample Planning/Tank Prioritization

Ie. Data Quality Objectives/Customers of Characterization Data

\section{ANALYTICAL DATA - SAMPLING OF TANK WASTE AND WASTE TYPES}

IIa. Sampling of tank 241-BY-112

IIb. Sampling of BY Saltcake Waste Type

\section{COMBINED ANALYTICAL/NON-ANALYTICAL DATA}

IIIa. Inventories using both Campaign and Analytical Information Imb. Compendium of Existing Physical and Chemical Documented Data Sources

This bibliography is broken down into the appropriate sections with an annotation at the end of each reference, or set of references, describing the information source. A majority of the information listed below is available in the Lockheed Martin Hanford Corporation Tank Characterization Safety and Resource Center. 


\section{NON-ANALYTICAL DATA}

Ia. Models/Waste Type Inventories/Campaign Information

Anderson, J. D., 1990, A History of the 200 Area Tank Farms, WHC-MR-0132, Westinghouse Hanford Company, Richland, Washington.

- Contains single-shell tank fill history and primary campaign/waste type information up to 1981 .

Jungfleisch, F. M. and B. C. Simpson, 1993, Preliminary Estimation of the Waste Inventories in Hanford Tanks Through 1980, WHC-SD-WM-TI-057, Rev. 0A, Westinghouse Hanford Company, Richland, Washington.

- Describes a model for estimating tank waste inventories using process knowledge, radioactive decay estimates using ORIGEN, and assumptions about waste types, solubility, and constraints.

Nguyen, D. M., 1989, Data Analysis of Conditions in Single-Shell Tanks Suspected of Containing Ferrocyanide, (internal letter 13314-89-025 to N. W. Kirch, March 2), Westinghouse Hanford Company, Richland, Washington.

- Gives estimates of the ferrocyanide content in a few tanks.

Schneider, K. J., 1951, Flowsheets and Flow Diagrams of Precipitation Separations Process, HW-23043, Hanford Atomic Products Operation, Richland, Washington.

- Contains compositions of process stream waste before transfer to 200 Area waste tanks.

\section{Ib. Fill History/Waste Transfer Records}

Agnew, S. F., P. Baca, R. A. Corbin, T. B. Duran, and K. A. Jurgensen, 1996, Waste Status and Transaction Record Summary, WSTRS Rev. 4, LA-UR-97-311, Rev. 0, Los Alamos National Laboratory, Los Alamos, New Mexico.

- Contains spreadsheets showing all known tank additions/transfers. 
Anderson, J. D., 1990, A History of the 200 Area Tank Farms, WHC-MR-0132, Westinghouse Hanford Company, Richland, Washington.

- Contains tank fill histories and primary campaign/waste type information up to 1981 .

Ic. Surveillance/Tank Configuration

Alstad, A. T., 1993, Riser Configuration Document for Single-Shell Waste Tanks, WHC-SD-MW-TI-053, Rev. 0, Westinghouse Hanford Company, Richland, Washington.

- Shows riser locations in relation to tank aerial view and a description of each riser and its contents.

Lipnicki, J., 1996, Waste Tank Risers Available for Sampling, WHC-SD-WM-TI-710, Rev. 3, Westinghouse Hanford Company, Richland, Washington.

- Assesses riser locations for each tank; however, not all tanks are included/completed. Also includes an estimate of the risers available for sampling.

Tran, T. T., 1993, Thermocouple Status Single-Shell and Double-Shell Waste Tanks, WHC-SD-WM-TI-553, Rev. 0, Westinghouse Hanford Company, Richland, Washington.

- Provides thermocouple location and status information for single- and double-shell tanks.

Welty, R. K., 1988, Waste Storage Tank Status and Leak Detection Criteria, WHC-SD-WM-TI-356, Rev. 0, Westinghouse Hanford Company, Richland, Washington.

- Provides leak detection information for all single- and double-shell tanks. Includes liquid level, liquid observation well, and drywell readings. 


\section{Id. Sample Planning/Tank Prioritization}

Brown, T. M., T. J. Kunthara, S. J. Eberlein, and J. W. Hunt, 1996, Tank Waste Characterization Basis, WHC-SD-WM-TA-164, Rev. 2, Westinghouse Hanford Company, Richland, Washington.

- Establishes an approach to determine the priority for tank sampling and characterization and identifies high-priority tanks for sampling.

Baldwin, J. H., 1997, Tank 241-BY-112 Push Mode Core Sampling and Analysis Plan, WHC-SD-WM-TSAP-110, Rev. 0A, Lockheed Martin Hanford Corporation for Fluor Daniel Hanford, Inc., Richland, Washington.

- Contains detailed sampling and analysis scheme for core samples to be taken from tank 241-BY-112 to address applicable DQOs.

Mulkey, C. H., 1996, Single-Shell Tank System Waste Analysis Plan, WHC-EP-0356, Rev. 1, Westinghouse Hanford Company, Richland, Washington.

- The waste analysis plan for single-shell tanks as required by WAC-173-303 and 40 CFR, Part 265.

Stanton, G. A., 1996, Baseline Sampling Schedule, Change 96-04, (internal letter 75610-96-11 to Distribution, August 22), Westinghouse Hanford Company, Richland, Washington.

- Provides a tank waste sampling schedule through fiscal year 2002 and lists samples taken since 1994.

Winkelman, W. D., 1996, Tank 241-BY-112 Tank Characterization Plan, WHC-SD-WM-TP-281, Rev. 2, Lockheed Martin Hanford Corporation for Fluor Daniel Hanford Inc., Richland, Washington.

- Discusses relevant DQOs and how their requirements will be met for tank 241-BY-112. 
Winkelman, W. D., J. W. Hunt, and L. J. Fergestrom, 1996, Fiscal Year 1997 Tank Waste Analysis Plan, WHC-SD-WM-PLN-120, Rev. 1, Lockheed Martin Hanford Corporation for Fluor Daniel Hanford Inc., Richland, Washington.

- Contains Hanford Federal Facility Agreement and Consent Order requirement-driven TWRS characterization program information and a list of tanks addressed in Fiscal Year 1997.

\section{Ie. Data Quality Objectives/Customers of Characterization Data}

Dukelow, G. T., J. W. Hunt, H. Babad, and J. E. Meacham, 1995, Tank Safety Screening Data Quality Objective, WHC-SD-WM-SP-004, Rev. 2, Westinghouse Hanford Company, Richland, Washington.

- Determines whether tanks are under safe operating conditions.

Meacham, J. E., 1996, Implementation Change Concerning Organic DQO, Rev. 2, (internal letter 2N160-96-006 to distribution, December 2), Duke Engineering and Services Hanford for Fluor Daniel Hanford, Inc., Richland, Washington.

- Changes the organic DQO strategy to test for TOC for any exotherm.

Meacham, J. E., 1996, Increase Scope To Organic DQO, (internal letter 2N160-96-003 to J. G. Kristofzski, October 31), Duke Engineering and Services, Inc. for Fluor Daniel Hanford Inc., Richland, Washington.

- Increases the scope of organic DQO to all single-shell tanks.

Osborne, J. W., J. L. Huckaby, E. R. Hewitt, C. M. Anderson, D. D. Mahlum, B. A. Pulsipher, and J. Y. Young, 1994, Data Quality Objectives for Generic In-Tank Health and Safety Vapor Issue Resolution, WHC-SD-WM-DQO-002, Rev. 0, Westinghouse Hanford Company, Richland, Washington.

- Determines whether tank vapor spaces contain potentially flammable levels of gases and vapors and/or whether there is a potential for worker hazards associated with the toxicity of constituents in any vapor emissions from the tanks. 
Osborne, J. W. and L. L. Buckley, 1995, Data Quality Objective for Tank Hazardous Vapor Safety Screening, WHC-SD-WM-DQO-002, Rev. 2, Westinghouse Hanford Company, Richland, Washington.

- Determines whether tank vapor spaces contain potentially hazardous gases and vapors.

Turner, D. A., H. Babad, L. L. Buckley, and J. E. Meacham, 1995, Data Quality Objective to Support Resolution of the Organic Complexant Safety Issue, WHC-SD-WM-DQO-006, Rev. 2, Westinghouse Hanford Company, Richland, Washington.

- Categorizes organic tanks as safe, conditionally safe, or unsafe based on fuel and moisture concentrations and supports resolution of the safety issue.

II. ANALYTICAL DATA - SAMPLING OF TANK WASTE AND WASTE TYPES

IIa. Sampling of Tank 241-BY-112

Anderson, T. D., 1972, Tank 112-BY Samples and Analyses, (internal letter 013172 to J. S. Buckingham, January 13), Atlantic Richfield Hanford Company, Richland, Washington.

Buckingham, J. S., 1971, Dissolution and Analysis of 112-BY Sludge and Crust Samples, (intemal letter 0-71-42 to D. J. Larkin, May 29), Atlantic Richfield Hanford Company, Richland, Washington.

- Contains solubility data and chemical analytical results from waste samples.

Buckingham, J. S., 1972, Analysis of Tank 112-BY Sample, (internal letter 040472 to T. D. Anderson, April 4), Atlantic Richfield Hanford Company, Richland, Washington.

- Contains analytical results from waste samples taken in January 1972. 
Caprio, G. S., 1995, Vapor and Gas Sampling of Single-Shell Tank 241-BY-112 Using the Vapor Sampling System, WHC-SD-WM-RPT-125, Rev. 0, Westinghouse Hanford Company, Richland, Washington.

- Contains vapor sampling analytical results from November 1994.

Huckaby, J. L. and D. R. Bratzel, 1995, Tank 241-BY-112 Heidspace Gas and Vapor Characterization Results for Samples Collected in November 1994, WHC-SD-WM-ER-441, Rev. 1A, Westinghouse Hanford Company, Richland, Washington.

- Contains vapor sampling analytical results from November 1994.

Schuelein, V. L., 1972, Dilution Requirements of High Salt Supernatants, (internal letter 071972 to T. D. Anderson, July 19), Atlantic Richfield Hanford Company, Richland, Washington.

- Contains results of dilution studies of tank 241-BY-112 waste samples.

Schulz, W. W., 1968, Characterization of the Organic Material in the 112-BY Tank, BNWL-CC-1517, Pacific Northwest Laboratory, Richland, Washington.

- Contains waste sampling analytical results.

Skolrud, J. O., 1971, Dissolution of BY112 Sludge Samples, (internal letter I-71-37 to J. S. Buckingham, April 26), Atlantic Richfield Hanford Company, Richland, Washington.

Wheeler, R. E., 1976, Analysis of Tank Farm Samples 12/18/1975 through 01/08/1976, (internal letter 010876 to R. L. Walser, January 8), Atlantic Richfield Hanford Company, Richland, Washington. 


\section{IIb. Sampling of BY Saltcake Waste Type}

Bell, K. E., J. Franklin, J. Stroup, and J. L. Huckaby, 1996, Tank Characterization Report for Single-Shell Tank 241-BY-106, WHC-SD-WM-ER-616, Rev. 0, Westinghouse Hanford Company, Richland, Washington.

- Contains characterization data for the waste in tank 241-BY-106 which includes BY saltcake.

Benar, C. J., J. G. Field, and L. C. Amato, 1996, Tank Characterization Report for Single-Shell Tank 241-BY-104, WHC-SD-WM-ER-608, Rev. 0, Westinghouse Hanford Company, Richland, Washington.

- Contains characterization data for the waste in tank 241-BY-104 which includes BY saltcake.

Buckingham, J. S., 1972, Exothermic Reactions in ITS Feed Solutions, (internal memorandum to D. J. Larkin, March 17), Atlantic Richfield Hanford Company, Richland, Washington.

- Contains differential thermal analysis results and gas chromatography results for ITS feed.

Metz, W. P., 1972, Nitric Acid Neutralization and Concentration of ITS Feed, (internal memorandum to J. S. Buckingham, June 2), Atlantic Richfield Hanford Company, Richland, Washington.

- Contains a general chemical analysis of ITS feed.

Simpson, B. C., J. G. Field, and L. M. Sasaki, 1996, Tank Characterization Report for Single-Shell Tank 241-BY-105, WHC-SD-WM-ER-598, Rev. 0, Westinghouse Hanford Company, Richland, Washington.

- Contains characterization data for the waste in tank 241-BY-105 which includes BY saltcake.

Simpson; B. C., R. D. Cromar, and R. D. Schreiber, 1996, Tank Characterization Report for Single-Shell Tank 241-BY-110, WHC-SD-WM-ER-591, Rev. 0, Westinghouse Hanford Company, Richland, Washington.

- Contains characterization data for the waste in tank 241-BY-110 which includes BY saltcake. 


\section{COMBINED ANALYTICAL/NON-ANALYTICAL DATA}

IIIa. Inventories using both Campaign and Analytical Information

Agnew, S. F., J. Boyer, R. A. Corbin, T. B. Duran, J. R. Fitzpatrick, K. A. Jurgensen, T. P. Ortiz, and B. L. Young, 1997, Hanford Tank Chemical and Radionuclide Inventories: HDW Rev. 4, LA-UR-96-3860, Rev. 0, Los Alamos National Laboratory, Los Alamos, New Mexico.

- Contains waste type summaries, primary chemical compound/analyte and radionuclide estimates for sludge, supernatant, and solids, as well as SMM, TLM, and individual tank inventory estimates.

Agnew, S. F., R. A. Corbin, J. Boyer, T. B. Duran, K. A. Jurgensen, T. P. Ortiz, B. L. Young, R. Anema, and C. Ungerecht, 1996, History of Organic Carbon in Hanford HLW Tanks: HDW Model Rev. 3, LA-UR-96-989, Los Alamos National Laboratory, Los Alamos, New Mexico.

- Attempts to account for the disposition of soluble organics and provides estimates of TOC content for each tank.

Allen, G. K., 1976, Estimated Inventory of Chemicals Added to Underground Waste Tanks, 1944 - 1975, ARH-CD-601B, Rev. 0, Atlantic Richfield Hanford Company, Richland, Washington.

- Contains major components for waste types and some assumptions. Purchase records are used to estimate chemical inventories.

Allen, G. K., 1975, Hanford Liquid Waste Inventory as of September 30 , 1974, ARH-CD-229, Rev. 0, Atlantic Richfield Company, Richland, Washington.

- Contains major components for waste types and some assumptions. 
Brevick, C. H., R. L. Newell, and J. W. Funk, 1996, Historical Tank Content Estimate for the Northeast Quadrant of the Hanford 200 East Area, WHC-SD-WM-ER-349, Rev. 1A, Westinghouse Hanford Company, Richland, Washington.

- Contains summary information for tanks in B, BX, and BY Tank Farms as well as in-tank photo collages and inventory estimates.

Geier, R. G., 1976, Estimated Hanford Liquid Wastes Chemical Inventory as of June 30, 1976, ARH-CD-768, Rev. 0, Atlantic Richfield Hanford Company, Richland, Washington.

- Contains nominal concentrations of various analytes for the liquid waste in some waste tanks.

Klem, M. J., 1988, Inventory of Chemicals Used at Hanford Production Plants and Support Operations (1944 - 1980), WHC-EP-0172, Westinghouse Hanford Company, Richland, Washington.

- Provides a list of chemicals used in production facilities and support operations that sent wastes to the single-shell tanks. List is based on chemical process flowsheets, essential materials consumption records, letters, reports, and other historical data.

Kupfer, M. J., 1996, Interim Report: Best Basis Total Chemical and Radionuclide Inventories in Hanford Site Tank Waste, WHC-SD-WM-TI-740, Rev. B-Draft, Westinghouse Hanford Company, Richland, Washington.

- Contains a global component inventory for 200 Area waste tanks. Fourteen chemical and two radionuclide components are inventoried currently.

Schmittroth, F. A., 1995, Inventories for Low-Level Tank Waste, WHC-SD-WM-RPT-164, Rev. 0, Westinghouse Hanford Company, Richland, Washington.

- Contains a global inventory based on process knowledge and radioactive decay estimations using ORIGEN2. Plutonium and uranium waste contributions are taken at one percent of the amount used in processes. Also compares information on Tc-99 from ORIGEN2 and analytical data. 
Toth, J. J., C. E. Willingham, P. G. Heasler, and P. D. Whitney, 1994, Organic Carbon in Hanford Single-Shell Tank Waste, PNL-9434, Pacific Northwest Laboratory, Richland, Washington.

- Contains organic carbon analytical results and model estimates for tanks.

IIb. Compendium of Existing Physical and Chemical Documented Data Sources

Agnew, S. F. and J. G. Watkin, 1994, Estimation of Limiting Solubilities for Ionic Species in Hanford Waste Tank Supernates, LA-UR-94-3590, Los Alamos National Laboratory, Los Alamos, New Mexico.

- Gives solubility ranges used for key chemical and radionuclide components based on supernate sample analyses.

Brevick, C. H., R. L. Newell, and J. W. Funk, 1996, Supporting Document for the Northeast Quadrant Historical Tank Content Estimate Report for BY Tank Farm, WHC-SD-WM-ER-312, Rev. 1A, Westinghouse Hanford Company, Richland, Washington.

- Contains summary information for tanks in the BY Tank Farm as well as appendixes containing more detailed information including tank waste level history, tank temperature history, cascade and drywell charts, riser information, in-tank photo collages, and tank layer model bar chart and spreadsheet.

Brevick, C. H., L. A. Gaddis, and E. D. Johnson, 1996, Tank Waste Source Term Inventory Validation, Vol I, II, and III, WHC-SD-WM-ER-400, Rev. 0A, Westinghouse Hanford Company, Richland, Washington.

- Contains a quick reference to sampling information in spreadsheet or graphical form for 24 chemicals and 11 radionuclides for all tanks.

Hanlon, B. M., 1997, Waste Tank Summary Report for Month Ending April 30, 1997, HNF-EP-0182-109, Westinghouse Hanford Company, Richland, Washington.

- Contains a summary of tank waste volumes, Watch List tanks, occurrences, tank integrity information, equipment readings, tank location, leak volumes, and other miscellaneous tank information. 
Hill, J. G., G. S. Anderson, and B. C. Simpson, 1995, The Sort on Radioactive Waste Type Model: A Method to Sort Single-Shell Tanks into Characteristic Groups, PNL-9814, Rev. 2, Pacific Northwest Laboratory, Richland, Washington.

- Document describes a system of sorting single-shell tanks into groups based on the major waste types contained in each tank.

Husa, E. I., 1993, Hanford Site Waste Storage Tank Information Notebook, WHC-EP-0625, Westinghouse Hanford Company, Richland, Washington.

- Contains in-tank photos and summaries of the tank description, leak detection system, and tank status.

Husa, E. I., 1995, Hanford Waste Tank Preliminary Dryness Evaluation, WHC-SD-WM-TI-703, Rev. 0, Westinghouse Hanford Company, Richland, Washington.

- Assesses the relative dryness of tank wastes.

Shelton, L. W., 1996, Chemical and Radionuclide Inventory for Single-and Double-Shell Tanks, (internal memorandum 74A20-96-30 to D. J. Washenfelder, February 28), Westinghouse Hanford Company, Richland, Washington.

- Contains a tank inventory estimate based on analytical information.

Shelton, L. W., 1995, Chemical and Radionuclide Inventory for Single- and Double-Shell Tanks, (internal memorandum 75520-95-007 to R. M. Orme on August 8), Westinghouse Hanford Company, Richland, Washington.

- Contains a tank inventory estimate based on analytical information.

Shelton, L. W., 1995, Radionuclide Inventories for Single- and Double-Shell Tanks, (internal memorandum 71320-95-002 to F. M. Cooney, February 14), Westinghouse Hanford Company, Richland, Washington.

- Contains a tank inventory estimate based on analytical information. 
Van Vleet, R. J., 1993, Radionuclide and Chemical Inventories for the Single-Shell Tanks, WHC-SD-WM-TI-565, Rev. 1, Westinghouse Hanford Company, Richland, Washington.

- Contains selected sample analysis tables before 1993 for single-shell tanks. 
This page intentionally left blank. 


\section{DISTRIBUTION SHEET}

\begin{tabular}{|c|c|c|c|c|c|}
\hline \multirow[b]{2}{*}{ Distribution } & \multirow{2}{*}{\multicolumn{3}{|c|}{$\begin{array}{l}\text { Data } A \\
\text { Inte }\end{array}$}} & \multicolumn{2}{|l|}{ Page 1 of 2} \\
\hline & & & & \multicolumn{2}{|c|}{ Date $\quad 05 / 08 / 97$} \\
\hline \multicolumn{4}{|c|}{ Project Title/Work Order } & \multicolumn{2}{|c|}{ EDT No. EDT-617661 } \\
\hline \multicolumn{4}{|c|}{$\begin{array}{l}\text { Tank Characterization Report for Single-She11 Tank 241-BY-112, } \\
\text { HNF-SD-WM-ER-701, Rev. } 0\end{array}$} & \multicolumn{2}{|c|}{ ECN No. N/A } \\
\hline - Name & MSIN & $\begin{array}{c}\text { Text } \\
\text { With All } \\
\text { Attach. }\end{array}$ & Text Only & $\begin{array}{l}\text { Attach./ } \\
\text { Appendix } \\
\text { Only }\end{array}$ & $\begin{array}{c}\text { EDT/ECN } \\
\text { Only }\end{array}$ \\
\hline
\end{tabular}

\section{OFFSITE}

Sandia Nationa] Laboratory

P.0. Box 5800

MS-0744, Dept. 6404

Albuquerque, NM 87815

D. Powers

Nuclear Consulting Services Inc.

P. 0. Box 29151

Columbus, OH 43229-01051

J. L. Kovach

Chemical Reaction Sub-TAP

P.0. Box 271

Lindsborg, KS 67456

B. C. Hudson

SAIC

20300 Century Boulevard, Suite 200-B

Germantown. MD 20874

H. Sutter

$x$

Los Alamos Laboratory

CST-14 MS-J586

P. 0. Box 1663

Los Alamos, NM 87545

S. F. Agnew

$X$

Los Alamos Technical Associates

T. T. Tran

B1-44 $x$

Tank Advisory Panel

102 Windham Road

Oak Ridge, TN 37830

D. 0. Campbel1

$x$ 


\section{DISTRIBUTION SHEET}

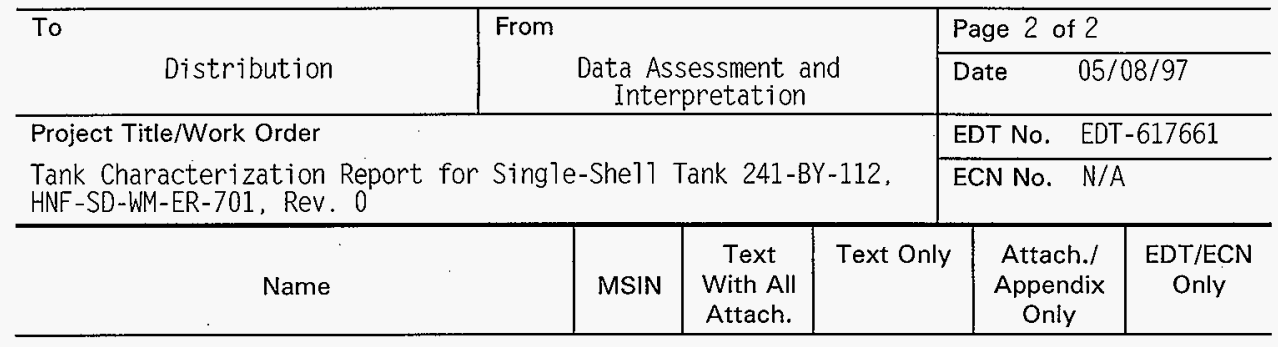

\section{ONSITE}

Department of Energy - Richland Operations.

J. F. Thompson

W. S. Liou

J. A. Poppiti

N. W. Willis

$\begin{array}{ll}57-54 & X \\ 57-54 & x \\ 57-54 & x \\ 57-54 & X\end{array}$

DE\&S Hanford, Inc.
R. J. Cash
W. L. Cowley
G. L. Dunford
G. D. Johnson
J. E. Meacham

$\begin{array}{ll}\text { S7-14 } & X \\ \text { R2-54 } & X \\ \text { A2-34 } & X \\ \text { S7-14 } & X \\ \text { S7-14 } & X\end{array}$

Fluor Daniel Northwest

J. L. Stroup

S3-09 $\quad x$

Lockheed Martin Hanford, Corp.

J. H. Baldwin

K. M. Hodgson

T. J. Kelley

L. M. Sasaki

B. C. Simpson

L. R. Webb

ERC (Environmental Resource Center)

$x$
$x$
$x$
$x$

T.C.S.R.C.

Lockheed Martin Services, Inc.

\section{B. G. Lauzon \\ Central Files \\ EDMC}

Numatec Hanford Corporation

J. S. Garfield

J. S. Hertzel

D. L. Lamberd

Pacific Northwest National Laboratory

A. F. Noonan

Rust Federal Services of Hanford, Inc.

C. T. Narquis
$\mathrm{R} 2-12$

$\mathrm{H} 0-34$

S7-21

$\mathrm{R} 2-12$

R2-12

R2-12

R1-51

RI-10

R1-08

A3-88

H6-08

H5-49

H5-61

H5-61

K9-91

$$
\begin{aligned}
& X \\
& X \\
& X \\
& X \\
& X \\
& X \\
& X \\
& 5
\end{aligned}
$$

$x$
$x$
$x$

T6-16 X 